UNIVERSIDADE DE SÃO PAULO

FACULDADE DE EDUCAÇÃO

ANA LAURA GODINHO LIMA

A Vontade de Psicologia na Formação de Professores

São Paulo

2019 


\section{A Vontade de Psicologia na Formação de Professores}

Tese apresentada ao Concurso de LivreDocência, junto à área de Psicologia do Departamento de Filosofia da Educação e Ciências da Educação da Faculdade de Educação da Universidade de São Paulo.

São Paulo 
Autorizo a reprodução e divulgação total ou parcial deste trabalho, por qualquer meio convencional ou eletrônico, para fins de estudo e pesquisa, desde que citada a fonte.

Catalogação na publicação

Serviço de Biblioteca e Documentação

Faculdade de Educação da Universidade de São Paulo. 
LIMA, Ana Laura Godinho. A vontade de psicologia na formação de professores. Tese (Livre-Docência em Educação) Faculdade de Educação da Universidade de São Paulo, São Paulo, 2019.

Aprovado em:

\section{Banca Examinadora}

Prof. Dr.

Instituição:

Julgamento:

Prof. Dr.

Instituição:

Julgamento:

Prof. Dr.

Instituição:

Julgamento:

Prof. Dr.

Instituição:

Julgamento:

Prof. Dr.

Instituição:

Julgamento: 


\section{À Denice Barbara Catani,}

muito especialmente.

Aos meus alunos e alunas, amigos e amigas da Universidade de São Paulo. 


\section{Agradecimentos}

À Fundação de Amparo à Pesquisa do Estado de São Paulo pelo financiamento dos dois projetos de pesquisa que deram origem a esta tese;

Ao Prof. Dr. Marcos Neira e ao Prof. Dr. Bruno Bontempi, pela confiança e pelo apoio à minha decisão de apresentar a tese,

À Prof ${ }^{\mathrm{a}}$. Dr ${ }^{\mathrm{a}}$. Denice Barbara Catani, pela generosidade com que se dispôs a ler a primeira versão da tese e do memorial e pelas observações e sugestões preciosas que me ofereceu em uma sequência de tardes agradabilíssimas, em bons cafés e restaurantes de São Paulo e em sua própria casa;

À Prof ${ }^{\mathrm{a}}$. Dr ${ }^{\mathrm{a}}$. Natália de Lacerda Gil, por se oferecer para ler a tese e o memorial do início ao fim, presentear-me com uma revisão tão rigorosa quanto cuidadosa de todo o trabalho e ainda me oferecer uma apreciação generosa do conjunto, uma demonstração de grande amizade;

À Prof ${ }^{\mathrm{a}}$. Dr ${ }^{\mathrm{a}}$. Ana Gabriela Godinho Lima, que gentilmente me ofereceu sua leitura e revisão criteriosas da primeira versão do memorial, cuja história conhece bem de perto;

À Prof ${ }^{\mathrm{a}}$. Dr ${ }^{\mathrm{a}}$. Graziela Serroni Perosa, pelo encorajamento e pelas sugestões estratégicas de organização do trabalho em seus momentos mais decisivos: o início e o fim;

À Prof ${ }^{\mathrm{a}}$. Dr ${ }^{\mathrm{a}}$. Carlota Boto, que, atendendo a um pedido meu de indicação bibliográfica, gentilmente me trouxe grande quantidade de livros para subsidiar as minhas pesquisas atuais e futuras;

Ao Prof. Dr. Julio Groppa Aquino, pelo incentivo enfático para que eu apresentasse a tese e por ter me oferecido em diferentes momentos indicações bibliográficas e advertências que foram de grande valor para a elaboração do texto;

À Gabriela Pinsdorf, pela revisão cuidadosa da versão em inglês do resumo; 
Ao Rafael Lima Iampolsky, que de boa vontade se dispôs a dedicar várias manhãs e tardes de suas férias de julho à cuidadosa digitalização dos documentos probatórios do currículo. Seu trabalho representou um auxílio decisivo na etapa de finalização da tese;

A Alexandre Gilsogamo, Aline Gama, Andressa Leme, Caio Ribeiro, Elaine Pires, Eliane Pereira, Gabriela Pinsdorf, Laiene Kadena, Lara Marin e Marina Luz, integrantes do grupo de pesquisa Pedagogia, Psicologia e Relações de Poder, pela interlocução que animou a elaboração das ideias contidas neste trabalho.

À Prof ${ }^{\mathrm{a}}$. Dr ${ }^{\mathrm{a}}$ Francini Venâncio de Oliveira, pela formatação da tese de acordo com as normas da Associação Brasileira de Normas Técnicas;

Agradeço ainda

À Katia Cristina Silva Forli Bautheney, minha amiga-irmã, obrigada pelo seu amor que me fortalece. Esta tese corresponde à minha versão do nosso horizonte de trabalho;

Aos meus amigos e amigas da Universidade de São Paulo, por partilharem comigo muitos e tão bons momentos, mas também as muitas e crescentes indignações, as preocupações, às vezes também o cansaço... São muitas as pessoas queridas, mas devo nomear Cintya Regina Ribeiro e Roni Cleber Dias de Menezes, que me acompanharam mais de perto e se interessaram pelo processo de elaboração desta tese; Gladys Beatriz Barreyro, Luciana Viviani, Valéria Cazetta e Verónica Marcela Guridi, Jefferson Agostini Mello e Rogério Monteiro de Siqueira, amigos da $\mathrm{EACH}$, que também me acompanham e apoiam, apesar da distância na cidade que nos afasta.

Aos amigos que se reuniram no âmbito dos Cursos de Difusão Cultural $A$ formação da biblioteca pessoal: efeitos refeitos e Obras literárias e seus efeitos educativos: Juliana de Souza Silva, Katiene Nogueira da Silva, Patrícia Amparo, Renata Marcílio Cândido, Vivian Batista da Silva, Denice e Roni mais uma vez. Nossos encontros tem sido como saraus...

Aos funcionários que se desdobram para proporcionar o apoio necessário à realização do ensino, da pesquisa e dos inumeráveis eventos acadêmicos na Faculdade de Educação e têm tido tanta paciência para atender do melhor modo possível às nossas demandas, que nem sempre chegam no formato devido ou com a antecedência necessária. Correndo novamente o 
risco de ser injusta, agradeço especialmente à Célia Cruz, do Departamento de Filosofia da Educação e Ciências da Educação; à Luci Mara Gimenez e à Daniela, do Centro de Gerenciamento de Projetos; ao Sidney Mauro Fontanetti, à Edinalva Intaschi e à Sueli Lourenço, da Assistência Técnica Acadêmica; ao Ricardo Dias Sacco, da Comissão de Pesquisa; à Valéria dos Santos e à Rosângela Ferreira da Comissão de Curso das Licenciaturas.

Finalmente, agradeço

À Ana Carolina Lima Iampolsky e ao Rafael Lima Iampolsky por suportarem bem a interferência da tese nas horas que deveriam ser só nossas, mas também por impedirem que a tese tomasse todo o nosso tempo;

À Rosilda Rosa de Jesus. Se eu não pudesse contar com a sua dedicação e a sua responsabilidade, dificilmente teria conseguido concluir este trabalho;

Enfim, agradeço emocionada aos integrantes do Five O'clock weekly tea: Maria Christina de Campos Godinho, Paulo Roberto Barbosa Lima, Ana Gabriela Godinho Lima, Christiana Godinho Lima, Ana Carolina Lima Iampolsky, Rafael Lima Iampolsky, Ana Luiza Lima Sasaki, Pedro Paulo Lima Sasaki, Caio Seeber de Oliveira, Márcio Sasaki e Cristina Monteiro Palacios. As raízes mais profundas do meu trabalho estão fincadas aí, em nossos afetos, na seriedade e na irreverência de nossas conversas, inclusive nas nossas divergências, as quais se dissolvem em nossa perseverança comum, que vem de longe e vai longe.

E ao Valmir Zuza, pelo exemplo de determinação que me anima, pelo amor que me conforta. 
Ai palavras, ai, palavras, que estranha potência, a vossa!

Ai, palavras, ai, palavras, sois de vento, ides no vento, no vento que não retorna, e, em tão rápida existência, tudo se forma e transforma!

Sois de vento, ides no vento e quedais, com sorte nova! Ai, palavras, ai, palavras, que estranha potência, a vossa!

Todo o sentido da vida

Principia à vossa porta;

O mel do amor cristaliza seu perfume em vossa rosa; sois o sonho e sois a audácia, calúnia, fúria e derrota...

A liberdade das almas, ai! com letras se elabora... e dos venenos humanos sois a mais fina retorta: frágil, frágil como o vidro e mais que o aço poderosa! Reis, impérios, povos, tempos, Pelo vosso impulso rodam...

(MEIRELES, Cecília. Romance LIII. Das Palavras Aéreas. Romanceiro da Inconfidência. In MEIRELES, Cecília. Flor de Poemas. $3^{\text {a }}$. Ed., Rio de Janeiro: Nova Fronteira, 1972.) 


\title{
RESUMO
}

\author{
LIMA, Ana Laura Godinho. A vontade de psicologia na formação de professores. Tese \\ (Livre-Docência em Educação) 204p. Faculdade de Educação da Universidade de São Paulo,
} São Paulo, 2019.

Este trabalho tem como objetivo caracterizar alguns aspectos dos discursos da psicologia divulgados no campo educacional brasileiro. Apresenta um conjunto de análises desses discursos que incidiram sobre manuais de psicologia educacional destinados à formação de professores e outros textos e documentos da psicologia e da pedagogia, as quais foram inspiradas na obra de Michel Foucault. Os capítulos examinam os discursos de diferentes ângulos e referem-se a intervalos temporais distintos no decorrer do século XX. Inicialmente, discorre-se sobre a vontade de psicologia na formação dos professores como vontade de saber a verdade sobre a natureza da criança e como vontade de poder educá-la de modo menos custoso e com melhores resultados. Em seguida, a análise volta-se para as posições de sujeito do enunciado características dos manuais da disciplina, dentre as quais sobressaem a de comentadores das obras dos teóricos estrangeiros e a de pesquisadores interessados na compreensão das crianças brasileiras. O terceiro capítulo descreve duas modalidades de intervenção psicológica na educação escolar: a formulação e aplicação de testes no âmbito da psicologia experimental para a identificação e a mensuração das capacidades dos escolares e o atendimento da "criança-problema" em serviços de higiene mental. No quarto capítulo o foco recai sobre as teorias psicológicas do desenvolvimento e o modo como se estabeleceram suas articulações com certas recomendações para a educação escolar e o trabalho dos professores, dentre as quais a indicação de que o currículo deveria ser adequado às fases do desenvolvimento. $\mathrm{O}$ capítulo seguinte, em continuidade com o anterior, incide ainda sobre o desenvolvimento, mas explora as semelhanças e as diferenças no modo como esse tema foi associado ao do progresso nos discursos dos manuais de psicologia educacional e de história da educação. O sexto capítulo é dedicado às relações entre psicologia, educação escolar e democracia nos textos da psicologia e da educação. O último capítulo detém-se sobre a análise de um enunciado fundamental, que atravessa o discurso da psicologia educacional ao longo de todo o período considerado e alcança os nossos dias: "É preciso adaptar o ensino às características do aluno". As análises realizadas evidenciaram que, longe de ter se configurado como o fundamento científico da pedagogia, a psicologia educacional correspondeu a uma formação discursiva heterogênea, de contornos incertos, sobre a qual recaíram grandes expectativas relativas às suas possíveis contribuições para a solução de dificuldades enfrentadas nas escolas, mas também uma série de questionamentos e críticas. Sua história é indissociável da história da escola de massas, pois foi em busca de soluções para problemas engendrados no interior das instituições escolares que a psicologia educacional pôde se desenvolver como ciência aplicada.

Palavras-chave: Formação de professores. Psicologia educacional. Psicologia da criança. História da educação. 


\begin{abstract}
LIMA, Ana Laura Godinho. The will of psychology in teacher education. Tese (Livre-

Docência em Educação) 204 p. Faculdade de Educação da Universidade de São Paulo, São

Paulo, 2019.
\end{abstract}

This paper aims to characterize some aspects of the psychological discourses published in the Brazilian educational field. It presents a set of analyzes of these discourses, which is inspired by Michel Foucault's work and it is focused on educational psychology textbooks for teacher training, and other texts and documents of psychology and pedagogy. The chapters examine discourses from different angles, and consider different time intervals throughout the twentieth century. Initially, the discussion surrounds the desire for psychology in teacher education field as a desire to comprehend not only the truth about the nature of the child, but also the desire for the power to be able to educate less costly, achieving better results. Then, the analysis turns to the types of authorship or to the subject positions of the utterance, typical of discipline textbooks, among which stand out the commentators of the foreign theorists work, and researchers interested in the understanding of Brazilian children. The third chapter describes two modalities of psychological intervention in school education: the formulation and application of tests in the field of experimental psychology for identification and measurement of student's abilities, and assistance for the "problem child" in the mental hygiene services. In the fourth chapter, the focus is on the psychological theories of development and how their articulations have been established with certain recommendations for school education and teachers' work, including the indication that the curriculum should be appropriate to the stages of development. The following chapter, in continuity with the previous one, still focuses on development, nevertheless it explores the similarities and differences in how this theme has been associated with the progress in the discourses of educational psychology and educational history textbooks. The sixth chapter is dedicated to the relations between psychology, school education and democracy in psychology and education texts. The last chapter focuses on the analysis of a fundamental statement that runs through the discourse of educational psychology throughout the period considered and reaches our days: "It is necessary to adapt teaching to the characteristics of the student". Analyses showed that, far from being the scientific basis of pedagogy, educational psychology corresponded to a heterogeneous discursive formation, with uncertain contours, on which high expectations were raised regarding its possible contributions to the solution of difficulties faced by children in school, but also a series of questions and critics. Its history is inseparable from the history of the school for the masses, as it was in search of solutions to problems engendered within school institutions that educational psychology could develop as an applied science.

Keywords: Teacher Training. Educational Psychology. Children Psychology. History of Education. 


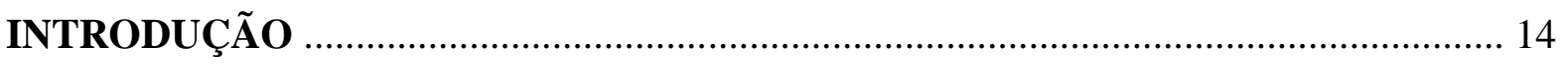

Vicissitudes da psicologia e da educação brasileiras no século XX ................................. 19

1. A "VONTADE DE PSICOLOGIA" COMO VONTADE DE VERDADE E DE PODER NA FORMAÇÀO DOS PROFESSORES..................................................................... 34

1.1 Vontade de verdade e de poder no ensino da psicologia aos professores brasileiros..39

2. AUTORES E MODOS DE ENTRADA NO DISCURSO: A PSICOLOGIA ENSINADA

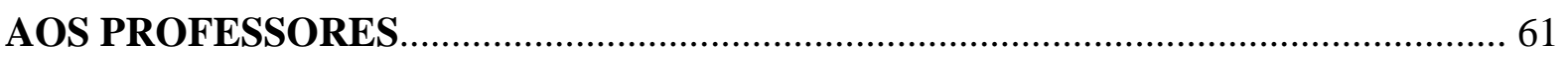

2.1 Considerações téorico-metodológicas sobre as modalidades enunciativas e a função autor

2.2 Os discursos da psicologia educacional destinados à formação de professores

3. A EXPERTISE E A TECHNE DA PSICOLOGIA APLICADAS À INVESTIGAÇÃO DO ALUNO NA ESCOLA

3.1 Os testes psicológicos para a avaliação das capacidades e da personalidade dos alunos 84

3.2 A "observação poligonal" e "em profundidade" ou o estudo "múltiplo"dos casos de desajustamento à escola

4. O IMPERATIVO DO "DESENVOLVIMENTO" NOS DISCURSOS DA PSICOLOGIA DIRIGIDOS A PROFESSORES...................................................... 102

4.1 O desenvolvimento humano como objeto para a ciência............................................ 104

4.2 A teoria evolucionista ensinada aos professores em São Paulo e no Rio de Janeiro..109

5. OS TEMAS DA EVOLUÇÃO E DO PROGRESSO NOS DISCURSOS DA PSICOLOGIA EDUCACIONAL E DA HISTÓRIA DA EDUCAÇÃO. 
5.1 Modernização e progresso da escola republicana

5.2 Considerações teórico-metodológicas.

5.3 A psicologia nos manuais de história e a história nos manuais de psicologia

5.4 Evolução e progresso nos manuais de história da educação e psicologia educacional 135

6. ESCOLA, PSICOLOGIA E DEMOCRACIA NOS DISCURSOS PEDAGÓGICOS 142

6.1 Considerações teórico-metodológicas

6.2 Educação, psicologia e democracia nos discursos dos anos 1930 e 1940 no Brasil..147

7. “É PRECISO ADAPTAR O ENSINO ÀS CARACTERÍSTICAS DO ALUNO”: análise histórica de um enunciado

7.1 Estudos psicológicos sobre a desigualdade das inteligências nos escolares

7.2 Psicologia, educação escolar e formação docente no Brasil. 167

7.3 Os professores devem adaptar o ensino às características dos alunos 172

CONCLUSÃO 179

REFERÊNCIAS .188 


\title{
INTRODUÇÃO
}

\begin{abstract}
O século XX foi certamente o século da psicologia - será que o século XXI será igual? O que quero dizer, quando coloco o século XX como século da psicologia, não é somente que esse foi o século em que a psicologia se transformou em disciplina, com departamentos universitários, professores especializados, diplomas, qualificações e esse tipo de coisa. Nem que esse foi o século em que a psicologia decolou como profissão: com corpos profissionais, qualificações, empregos relacionados e muito mais. Penso que, mais do que isso, esse foi o século da psicologia, porque a psicologia através do século XX ajudou a construir a sociedade em que nós vivemos e também o tipo de pessoas em que nos transformamos (ROSE, 2008, p. 155).
\end{abstract}

Se o século XX foi o século da psicologia, pode-se acrescentar que foi também o século da psicologia educacional ${ }^{1}$, não apenas porque foi nesse período que ela se estabeleceu como uma disciplina dominante na formação docente e surgiram os laboratórios de psicologia experimental associados às escolas normais, as clínicas e os consultórios psicológicos em que crianças com dificuldades na escola passaram a ser atendidas e a psicopedagogia como especialidade, mas principalmente porque a própria concepção de aluno e da relação pedagógica passou a ser compreendida em termos psicológicos e porque as propostas de renovação da escola e das práticas educativas invariavelmente buscaram fundamentação científica na psicologia.

Esta investigação caracteriza alguns aspectos centrais dos discursos da psicologia transmitidos aos professores em formação, com o objetivo de compreender como participaram na formação dos saberes sobre os alunos e como se procurou derivar desses saberes recomendações para as práticas pedagógicas. Por outro lado, identifica certas dúvidas, críticas e questionamentos relativos à apropriação da psicologia no campo educacional formuladas nesses mesmos discursos. Orienta-se pelo propósito de examinar os modos de aparição e

\footnotetext{
${ }^{1}$ Psicologia educacional, Psicologia da Educação, Psicologia Escolar, Psicologia e Educação são diferentes expressões empregadas no decorrer do século XX para fazer referência aos diferentes modos como a psicologia compareceu no campo educacional. Seu emprego não é indiferente para os especialistas da área, a opção por um ou outro identifica tanto concepções divergentes das interações entre a psicologia e a educação quanto expressa disputas políticas sobre qual deve ser a atuação do psicólogo na escola (AQUINO, 2014; SALVADOR,1999) Neste trabalho, que examina os discursos da disciplina a partir de uma perspectiva histórica, optou-se por "psicologia educacional", que foi a primeira designação empregada para fazer referência à psicologia dedicada especificamente ao estudo das questões educacionais.
} 
transformação de um conjunto de enunciados fundamentais nos discursos que relacionam os saberes da psicologia sobre a criança aos processos de escolarização no decorrer do século XX, período em que a psicologia alcançou enorme prestígio na formação dos professores, mas também sofreu uma série de críticas relativas aos seus efeitos e interferências na vida escolar. Recorre para isso à perspectiva arqueológica de análise do discurso de Michel Foucault e à história crítica da psicologia empreendida por Nikolas Rose. Toma como fontes textos reconhecidos como referências fundamentais para a psicologia educacional e também se vale de textos "menores", que não adquiriram grande repercussão mas encorparam a produção e a circulação do discurso, como é o caso dos manuais empregados nas escolas normais, cursos de pedagogia e licenciatura para dar a conhecer aos professores os conhecimentos da psicologia sobre o aluno, sua inteligência, sua aprendizagem, seu desenvolvimento ${ }^{2}$. Ao considerar não apenas os textos oficiais e as obras dos autores consagrados, mas também os manuais escritos por professores que não chegaram a se tornar grandes referências na disciplina, esta pesquisa aproxima-se da produção acadêmica contemporânea no campo da história da educação dedicada à caracterização da cultura escolar. Assume que a escola como instituição não apenas transmite ou reproduz a cultura produzida em outras instâncias - nas universidades, nos laboratórios, no meio artístico - mas também produz cultura, cria objetos, discursos, práticas e relações entre os sujeitos (AZANHA, 1990-1991; JULIA, 2001, SILVA, 2018). Nessa perspectiva, os manuais escritos para apoiar o ensino não são considerados meras simplificações da produção intelectual dos grandes autores, mas como produtos culturais com propósitos e características próprios - assim como os programas de ensino, as avaliações ou os jornais produzidos por alunos -, cuja análise contribui para a compreensão da cultura escolar em sua especificidade.

Já há décadas, pesquisadores brasileiros das áreas da psicologia, da história e da educação vêm buscando elucidar diferentes aspectos das relações que se estabeleceram entre a psicologia e a educação desde o século XIX. Tais investimentos geraram uma extensa produção bibliográfica e uma apresentação exaustiva do conjunto dessas investigações não corresponde ao propósito desta pesquisa. Graças a essas contribuições, dispomos atualmente de um conjunto expressivo de dados e análises acerca das instituições onde se desenvolveram os primeiros trabalhos de psicologia voltados para o estudo dos problemas das crianças e sua educação (CAMPOS, 2002; CAMPOS, 2004 a; CAMPOS, 2004b; MOTA, 2005; ANTUNES, 2007; 
ANTUNES, 2012; JACÓ-VILELA, 2012; JACÓ-VILELA et al, 2017). Já se realizaram levantamentos das obras e autores que compuseram a bibliografia dos cursos de psicologia para professores, favorecendo uma visão geral dos temas e das apropriações da produção estrangeira na estruturação do ensino da psicologia em nosso país (MONARCHA, 1999; JACÓ-VILELA, 2012). Outros trabalhos dedicaram-se ao estudo dos manuais de psicologia, tomando-os como fonte para a investigação de questões relativas à sua materialidade e aos seus conteúdos (CYSNEIROS, 1985; ANGELINI; PFROMM NETO \& ROSAMILHA, 2001; LANCILLOTTI, 2013) ou à identificação do modo como apresentam determinadas teorias, por exemplo o behaviorismo (GIOIA, 2001); as teorias sobre o desenvolvimento infantil (GOUVÊA \& BAHIENSE, 2011; EDDINE, 2013) e a teoria histórico-cultural de Vigotski (JÁCOME, 2006).

Esta investigação beneficia-se dessas análises e reconhece sua importância, mas se orienta por uma perspectiva distinta. $\mathrm{O}$ que busca não é verificar como um determinado conteúdo da psicologia, uma teoria ou um conceito em particular foi tratado nos manuais, com que grau de rigor, correção ou, ao contrário, de simplificação e distorção. Não se pretende examinar os discursos da psicologia como documentos que se referem a outras coisas ( $a$ psicologia, suas teorias, seus conceitos, suas verdades, seus usos legítimos ou ilegítimos, ou os autores, suas concepções, suas preocupações, seus interesses). Propõe-se a examiná-los em seus próprios termos, como coisas raras dotadas de uma história e de características próprias, como se fossem monumentos, cujos modos de aparição e propriedades importa compreender. Interessa analisá-los em suas relações com uma série de outros acontecimentos, discursos e objetos - instituições e programas de ensino, laboratórios, teorias, testes, artigos de periódicos - dos quais não são espelhos fiéis e nem cópias distorcidas. Os discursos da psicologia transmitidos aos professores tampouco são tomados aqui como a descrição simplificada de conteúdos cujo sentido genuíno estaria por trás dos enunciados manifestos ou cuja integridade seria preciso restituir a partir do retorno aos autores e às fontes originais. São, ao invés disso, entendidos como coisas ao lado de outras coisas, de outros discursos. Tendo em vista as considerações de Foucault em A arqueologia do saber, a análise que se pretende empreender renuncia a considerar os enunciados da psicologia do desenvolvimento transmitida aos professores como “'tradução’ de operações ou de processos que se desenrolam em algum outro lugar (no pensamento dos homens, em sua consciência ou em seu inconsciente, na esfera das constituições transcendentais)". Em vez disso, seguindo o autor (2004, p. 138), sugere que o enunciado 
Seja aceito, em sua modéstia empírica, como local de acontecimentos, de regularidades, de relacionamentos, de modificações determinadas, de transformações sistemáticas; em suma, que seja tratado não como resultado ou vestígio de outra coisa, mas como um domínio prático que é autônomo (apesar de dependente) e que se pode descrever em seu próprio nível (se bem que seja preciso relacioná-lo com algo que não seja ele).

No texto "Uma história crítica da psicologia", Nikolas Rose (2011) apresenta uma caracterização das maneiras como vem sendo escritas diferentes histórias da psicologia e delineia outro percurso de investigação, que se distancia principalmente da modalidade designada por Georges Canguilhem como "história recorrente", a qual consiste tanto em legitimar uma disciplina no tempo presente, vinculando-a a uma tradição honrada, quanto em separá-la dos aspectos de seu passado que poderiam ameaçar a sua reputação. As histórias recorrentes consideram os objetos das ciências às quais se referem como dotados de uma realidade natural e a-histórica, ou seja, como entidades preexistentes às ciências que os estudam. Consistem em narrativas dos modos como as ciências foram progressivamente se aproximando e se apropriando de seus objetos, até chegar ao seu estágio de compreensão atual. Têm um papel constitutivo fundamental para as disciplinas científicas,

\footnotetext{
pois elas usam o passado para ajudar a demarcar aquele regime de verdade que é contemporâneo para a disciplina - e, assim fazendo, elas não só usam a história para policiar o presente, como também para modelar o futuro (...). Tais histórias policiam as fronteiras de sua disciplina através de seus critérios de inclusão ou exclusão. Consequentemente, tais histórias contribuem para o estabelecimento da divisão entre o dizível e o indizível, o pensável e o impensável: para a demarcação do que Michel Foucault denominou 'regime de verdade' (ROSE, 2011, p. 67).
}

Alternativamente, Rose dedica-se à escrita de uma história crítica da psicologia segundo a qual os objetos da disciplina não lhe são exteriores, mas produtos de seus próprios desenvolvimentos. Busca compreender como se constituíram - por meio da formulação de que problemas, procedimentos de pesquisa e modos de intervenção em diferentes instâncias sociais - objetos como a inteligência, o caráter, a afetividade e o próprio indivíduo, como sujeito dotado dessas dimensões psicológicas e como objeto para uma ciência psicológica. Investiga as práticas por meio das quais se produziram as verdades sobre esses objetos. Não considera o presente como o apogeu do passado, o ponto de vista a partir do qual se estabelece o julgamento dos eventos pretéritos. Embora tome o presente da disciplina como centro da análise, o autor trata de problematizá-lo, procura verificar por meio de que disputas para a imposição de determinados objetos, verdades e procedimentos, simultaneamente à exclusão de outros tantos, a disciplina assumiu a sua forma contemporânea. Lembra que 
O que hoje parece marginal, excêntrico ou desonrado foi frequentemente, na época em que foi escrito, central, normal e respeitável. Ao invés de marginalizar esses textos do passado a partir do ponto de vista do presente, faríamos melhor ao questionar as certezas do presente, atentando para tais margens e para o processo de sua marginalização (ROSE, 2011, p. 67).

A caracterização desses discursos pode favorecer a compreensão de suas principais transformações, associadas ao surgimento de novas teorias e métodos de estudo, mas também às críticas que se foram fazendo às teorias existentes e seus efeitos percebidos na educação escolar e outros acontecimentos. As análises que compõem este trabalho pretendem contribuir para a elucidação das questões anteriormente formuladas e também as seguintes: O que era possível dizer e já não o é mais? O que ainda reconhecemos como verdadeiro e valioso nesses textos? Espera-se que a caracterização desses discursos que, em parte já deixaram de ser os nossos, em parte continuam a expressar nossas atuais convicções, possa favorecer a compreensão da nossa própria ambivalência em relação à psicologia e suas promessas para a educação escolar.

Os dois projetos de pesquisa ${ }^{3}$ que deram origem à escrita deste trabalho propuseramse a abarcar todo o século XX, mas seus capítulos apresentam recortes temporais mais limitados. Os dois capítulos iniciais correspondem ao núcleo da tese e privilegiam a explicitação da perspectiva teórica que fundamenta a investigação, embora também elaborem a análise de um conjunto de fontes. O primeiro caracteriza a articulação entre vontade de verdade e vontade de poder nos discursos da Escola Nova veiculados entre os anos 1930 e 1950 no Brasil. Evidencia um deslocamento da vontade de verdade do discurso do professor, representante da cultura socialmente legitimada, para os discursos da psicologia sobre a natureza da criança. Defende-se que, no nível do discurso, tal deslocamento teve consequências importantes para a educação, as quais dizem respeito ao propósito da educação e à fonte de sustentação da autoridade docente. Doravante, já não se tratava de transmitir a cultura às novas gerações, mas de favorecer o desenvolvimento das crianças para o mundo moderno, para o futuro, de torná-las capazes de produzir novos conhecimentos a partir de seus próprios interesses e de sua atividade espontânea. A autoridade do professor deixava de se apoiar

\footnotetext{
${ }^{3}$ Os projetos, realizados em sequência nos últimos anos, têm como títulos: A psicologia ensinada aos professores: uma análise dos discursos dirigidos a professores em formação (FAPESP, 2015-2017) e O imperativo do desenvolvimento na educação: uma análise dos discursos da psicologia dirigidos a professores (FAPESP, 2018-2020).
} 
principalmente no seu conhecimento, em sua experiência, para se fundamentar em seu saber sobre o desenvolvimento do aluno.

O segundo capítulo caracteriza as exigências que se impõem aos intelectuais ao adentrarem uma formação discursiva, recorrendo aos escritos de Foucault sobre a análise do discurso. Examina as condições requeridas para ocupar a posição de sujeito do enunciado, bem como as regras subjacentes à formação dos objetos, dos conceitos e à escolha das teorias e temas, os quais tanto permitem como restringem as possibilidades de formação dos enunciados. A análise incide especificamente sobre os discursos da psicologia destinados aos professores em formação, examinando a hipótese de que, na primeira metade do século 20, o tema do desenvolvimento tratado no âmbito da teoria da recapitulação constituiu uma estratégia recorrente para a formulação de enunciados reconhecidos como verdadeiros. Os cinco capítulos seguintes podem ser lidos como desdobramentos dos capítulos iniciais e examinam diferentes aspectos dos discursos da psicologia educacional, embora tenham sido escritos como artigos separados. Optou-se por preservar a forma original dos textos para permitir a leitura independente de cada um, assim algumas reiterações podem ser observadas, principalmente no que diz respeito às explicações sobre os modos de realizar as análises.

Para proporcionar uma visão geral de certos acontecimentos decisivos para a história da psicologia e da educação no Brasil ao longo do século XX, apresenta-se a seguir um breve retrospecto em que se procura explicitar as questões nas quais se detêm os capítulos seguintes. Depois disso, renuncia-se a essa modalidade de narrativa linear e faz-se referências aos seus eventos apenas na medida em que se mostrem relevantes para a elucidação do problema investigado em cada capítulo.

\section{Vicissitudes da psicologia e da educação brasileiras no século XX}

A instituição de um sistema público de educação no Brasil na Primeira República pode ser considerada como parte do processo mundial de difusão da escola de massas ocorrido na passagem do século XIX para o século XX, quando vários Estados nacionais envidaram esforços na educação do povo, tendo em vista a disseminação de uma cultura nacional comum, a formação de hábitos civilizados e a preparação para o trabalho. Estabeleceram-se então as escolas públicas seriadas que consagraram um modo de funcionamento que ainda hoje nos é 
familiar. A escola em que os alunos são reunidos em classes da mesma faixa etária para favorecer o ensino simultâneo; em que um professor generalista se encarrega do ensino das crianças nas séries iniciais, enquanto diversos professores especialistas se alternam no ensino dos alunos das séries mais adiantadas; onde o ensino ocorre predominantemente no espaço da sala de aula e por meio de uma previsão mais ou menos rígida do tempo dedicado aos diferentes conteúdos previstos no currículo e que prevê a realização de exames periódicos para controlar os resultados do trabalho realizado (NÓVOA, 1996, p. 20). Numa tal escola, em que se espera que os alunos caminhem juntos no aprendizado dos conteúdos e na aquisição dos comportamentos requeridos, aqueles que não correspondem ao esperado, porque se atrasam ou não se comportam como devem, sobressaem como problemas para os professores e a administração do ensino. Problemas que se procurou enfrentar por diversos meios, incluindo o recurso à psicologia, cujo desenvolvimento no país esteve estreitamente associado às atividades realizadas nas Escolas Normais para a formação de professores:

\begin{abstract}
A produção das Escolas Normais consistiu, provavelmente, numa das mais importantes contribuições para o estabelecimento da psicologia científica no Brasil, quer no âmbito teórico, quer no âmbito da aplicação prática de seus conhecimentos. Sua importância reside também no fato de muitos dos primeiros profissionais da psicologia terem iniciado sua formação nessas escolas e terem sido elas incentivadoras da publicação das primeiras obras específicas de psicologia no país (ANTUNES, 2007, p. 75).
\end{abstract}

Dada a motivação de produzir conhecimentos objetivos sobre o aluno, a partir dos quais se pretendia promover uma renovação científica das práticas escolares, as escolas normais tornaram-se espaços privilegiados para a produção e aplicação dos conhecimentos da psicologia. No domínio da educação escolar, a introdução da psicologia criou a expectativa da possibilidade de uma distribuição mais racional dos alunos nas turmas em função de suas capacidades, o que permitiria individualizar o ensino tanto quanto possível, numa escola organizada para promover a educação simultânea. Esperava-se dessa maneira melhorar o rendimento e reduzir as altas taxas de reprovação que se verificavam sobretudo na primeira série da escola primária.

No capítulo $O$ imperativo do 'desenvolvimento' nos discursos da psicologia dirigidos a professores no decorrer do século $X X$ a análise incide sobre um tema central nos discursos em defesa da renovação da escola. Efetua-se o exame dos discursos da psicologia veiculados no campo educacional para caracterizar as referências à teoria evolucionista, que proporcionou legitimidade científica à psicologia do desenvolvimento, ao mesmo tempo em que fortaleceu a 
tese do determinismo biológico, especialmente por meio da divulgação dos trabalhos de Spencer, que estabelecia diferenças de capacidades irreversíveis entre os grupos humanos designados como primitivos ou civilizados, atribuídas à hereditariedade e ao seu percurso evolutivo.

O ensino sistemático da psicologia nas escolas normais ocorreu a partir das primeiras décadas do século XX. Inicialmente, isso se deu por meio do desdobramento da disciplina Pedagogia em Pedagogia e Psicologia, tal como ocorreu em São Paulo, a partir de 1911, e no Rio de Janeiro. Embora a disciplina estivesse prevista no currículo da Escola Normal de São Paulo desde 1892, no âmbito da disciplina Psicologia, Moral e Educação Cívica, essa provavelmente não chegou a ser ensinada, pois foi logo suprimida e seus conteúdos foram incorporados à matéria Pedagogia e Direção de Escolas. Anos mais tarde, na reforma curricular da instrução pública de 1911 retomou-se a disciplina, que passou a representar o fundamento científico da educação escolar e a modernização do currículo. Oscar Thompson, então Diretor do Ensino, providenciou a instalação de gabinetes de antropologia e psicologia pedagógica nas três escolas normais secundárias paulistas, para permitir a realização de medidas psico-antropométricas dos alunos, a formação de classes homogêneas e a adaptação do ensino às diferenças individuais. Apesar disso, durante a maior parte do primeiro período republicano, a psicologia foi ensinada na Escola Normal de São Paulo como parte do conteúdo de disciplinas mais abrangentes: Pedagogia e Direção de Escolas (1893); Psicologia Experimental, Pedagogia e Educação Cívica (1911). De 1920 em diante, por iniciativa de Sampaio Dória, a matéria que ele próprio lecionava desde 1914 foi desmembrada em três disciplinas independentes (TAVARES, 1995; MONARCHA, 1999). Segundo Lourenço Filho (1954), a introdução da psicologia no currículo de formação dos professores também não se fez de forma definitiva no Distrito Federal, onde a disciplina foi facultativa por vários anos. Em 1928, a psicologia foi oficialmente inserida no currículo das escolas normais por meio de um decreto, simultaneamente à incorporação da pedagogia, da história da educação, da didática, da sociologia, da higiene e da puericultura (ANTUNES, 2007).

O Capítulo Os temas da Evolução e do progresso nos discursos da psicologia educacional e da história da educação consiste na análise de um conjunto de manuais de psicologia educacional e história da educação destinados à formação docente, cujo objetivo é identificar as aproximações e os distanciamentos entre essas disciplinas no que se refere à presença dos temas da evolução e do progresso. Incide sobre dez manuais publicados no Brasil 
entre 1934 e 1972, nos quais foi possível perceber a recorrência da associação entre o desenvolvimento da criança e o progresso social, frequentemente descritos à luz da teoria da recapitulação, que estabelecia um paralelismo entre o desenvolvimento do indivíduo e a evolução da espécie. Essa teoria constituiu foco de controvérsia, representando um aspecto do debate entre educadores escolanovistas e católicos no período considerado.

Paralelamente à criação dos grupos escolares e das escolas normais, diversos estados brasileiros criaram seus próprios laboratórios para o estudo dos alunos nas primeiras décadas do século XX. Em 1906 foi criado o Laboratório de Psicologia Experimental no Pedagogium, no Rio de Janeiro, planejado por Alfred Binet e por Manoel Bomfim, que se tornou o seu diretor (ANTUNES, 2007). No ano de 1914 foi instalado na Escola Normal de São Paulo o primeiro Gabinete de Antropologia Pedagógica e Psicologia Experimental do Estado, por iniciativa de Oscar Thompson, que ocupava o cargo de diretor da instituição. (TAVARES, 1995; CARVALHO, 1997). Os estudos especializados sobre os escolares desenvolvidos nesse gabinete foram inicialmente conduzidos sob a assistência do professor italiano Ugo Pizzoli, da Escola Normal de Modena. Pizzoli ministrou cursos sobre antropologia e psicologia pedagógica para os professores paulistas e propôs a criação da Carteira Biográfica Escolar do aluno, documento onde seriam reunidas fotografias anuais, informações sobre a família e os resultados das medidas obtidas pelo aluno nos exames fisiopsicológicos a que era submetido.

À criação dos primeiros laboratórios no Rio de Janeiro e em São Paulo, seguiram-se diversas outras iniciativas. O Instituto de Psicologia de Pernambuco foi fundado em 1925 por iniciativa de Ulysses Pernambucano, diretor da Escola Normal Oficial de Pernambuco. Pernambucano, considerado um precursor da educação das crianças deficientes mentais no Brasil, criou a "Escola para Anormais", anexa ao curso de aplicação da Escola Normal, entre outras instituições para a educação de "deficientes" (ANTUNES, 2007). Deve-se destacar ainda o trabalho empreendido por Helena Antipoff, psicóloga russa que foi discípula de Claparède no Instituto Jean-Jacques Rousseau em Genebra, posteriormente se estabeleceu no Brasil e instituiu um Laboratório de Psicologia em Minas Gerais, com o objetivo de subsidiar as ações daquele Estado no campo educacional. Essa psicóloga também se dedicou à educação das crianças "deficientes" e fundou a Sociedade Pestalozzi de Belo Horizonte em 1932, destinada a "promover o cuidado das crianças excepcionais e assessorar as professoras de classes especiais dos grupos escolares" (ANTIPOFF, 1937 apud CAMPOS et al., 2002, p. 24). 
À medida que se introduziam no país os conhecimentos da psicologia experimental e da psicanálise e se criavam as primeiras instituições dedicadas ao estudo dos problemas apresentados pelas crianças na escola, realizaram-se reformas educacionais em diversos estados brasileiros, as quais permitiram ampliar a população escolarizada. Estiveram à frente dessas reformas educadores proeminentes: Anísio Teixeira (Bahia), Francisco Campos (Minas Gerais), Fernando de Azevedo (Distrito Federal) e Lourenço Filho (Ceará e São Paulo). Em 1925, Lourenço Filho assumiu a cátedra de psicologia e pedagogia na Escola Normal de São Paulo, ocupada anteriormente por Sampaio Dória e retomou as atividades no laboratório organizado por Ugo Pizzoli. Nesse período, auxiliado por Noemy Silveira Rudolfer e outros profissionais, dedicou-se à realização de testes de desenvolvimento mental, além de pesquisas sobre jogos, leitura, cinema e aprendizagem. Desenvolveu-se também nesse laboratório a investigação de Lourenço Filho sobre a maturidade necessária à aprendizagem da leitura e da escrita, que daria origem aos testes ABC (LOURENÇO FILHO, 1954, p. 276).

As questões da educação, anteriormente pensadas e conduzidas por homens públicos e intelectuais de outras áreas, tornava-se matéria de especialistas e profissionais especialmente dedicados ao ensino escolar. Nos anos de 1920 ampliou-se a quantidade de publicações dedicadas às questões educacionais, favorecendo a ampliação do conhecimento especializado na área (NAGLE, 1976). A Biblioteca de Educação, dirigida por Lourenço Filho surgiu nesse período e publicou diversos livros de psicologia, escritos por autores brasileiros e estrangeiros. Entre 1927 e 1930 vieram a lume, entre outros, os seguintes títulos: Psychologia experimental (1927), de Henri Piéron; A escola e a psicologia experimental (1928), de Édouard Claparède; Temperamento e caráter sob o ponto de vista educativo (1928), de Henrique Geenen; A lei biogenética e a escola ativa (1929), de Adolphe Ferriére; Testes para a medida do desenvolvimento da inteligência (1929) de Alfred Binet e Th. Simon; Introdução ao Estudo da Escola Nova (1930), do próprio Lourenço Filho e Vida e educação (1930), de John Dewey (RITO, 2015; JACÓ-VILELA, 2012, p. 37; MONARCHA, 1997). Buscou-se então promover a renovação da escola pública e dos seus métodos, mediante a apropriação dos novos princípios pedagógicos que se difundiam na Europa e nos Estados Unidos no âmbito do movimento da Escola Nova.

Como se sabe, a Escola Nova defendia uma profunda transformação no ensino, ao postular que a criança deveria tornar-se o centro da atividade escolar e não mais o professor. Em vez de instituição destinada a transmitir aos mais novos a cultura elaborada pelas gerações 
precedentes, entendia-se que era preciso transformar a escola em uma espécie de laboratório do futuro. A concepção de que o desenvolvimento do indivíduo era paralelo ao da sociedade relacionava-se à convicção de que favorecer o desenvolvimento das crianças, futuro da humanidade, era medida que se impunha para assegurar o progresso da sociedade. À escola cabia acolher as motivações infantis e proporcionar aos alunos oportunidades de observar, agir e experimentar livremente, tendo em vista o desenvolvimento de suas capacidades psicológicas. A atividade e os interesses do aluno passavam a comandar o aprendizado e não mais o ensino de conteúdos definidos pelos adultos e a autoridade do professor. Valorizavamse os conhecimentos científicos assimilados na prática, assim como as atividades cooperativas, visando-se à formação de indivíduos responsáveis e autônomos, capazes de governar a si próprios em uma sociedade democrática. Configurava-se a utopia do homem aprimorável, segundo a feliz expressão formulada por Marcelo Rito (2015). O ensino das diferentes disciplinas tornou-se objeto de estudo especializado, buscando-se estabelecer cientificamente quais as práticas de escrita e de leitura mais favoráveis ao aprendizado do aluno, quais os métodos mais eficientes para a compreensão dos elementos da natureza. Procurou-se, na medida do possível, adquirir materiais para a realização de experimentos, equipar as escolas com bibliotecas e museus, realizar excursões e aulas de campo, assim como trabalhos em grupo e atividades ao ar livre (VIDAL, 2011).

Nos discursos especializados desse período a criança foi transformada em razão de ser da pedagogia e em objeto privilegiado de investigação nas instituições onde se desenvolvia a psicologia científica nascente, cuja contribuição passou a ser intensamente solicitada para iluminar os caminhos que deveriam ser seguidos na renovação do ensino. A partir das reformas educacionais e da renovação dos currículos das escolas normais, a psicologia passou a ser valorizada, sobretudo suas especialidades dedicadas ao estudo da infância e das diferenças individuais. Conforme Nagle (1976, p. 247),

\footnotetext{
A posição da psicologia é singular nesse quadro. Os estudos psicológicos aparecem sob a forma de psicologia geral, outras vezes com determinadas especificações que revelam modificações importantes no seu conteúdo; por exemplo, neste caso englobam itens sobre o estudo da criança, do desenvolvimento humano, dos interesses e necessidades, das diferenças individuais. Além disso, aparecem determinadas denominações especiais, que denotam especializações, como é o caso da psicologia do desenvolvimento, pedologia, psicometria, psicologia educacional, psicologia das vocações. De uma ou de outra forma, a psicologia aparece, muitas vezes, como o principal domínio científico que fornece os recursos para transformar a escolarização numa técnica altamente racionalizada e, assim libertá-la de uma série de concepções errôneas, segundo as quais a tarefa educativa é, exclusivamente, questão de tato, de dom, de intuição, de prática, de vocação; com efeito é por meio
} 
dos estudos psicológicos que se conhece a natureza da criança, a dinâmica dos seus interesses e desejos, as leis do seu crescimento mental, as suas tendências.

A educação renovada exigia do professor que renunciasse a ser uma figura de autoridade diante dos alunos e passasse a ser, em primeiro lugar, um observador atento da criança, de seus interesses e suas atividades. Para a Escola Nova, a educação escolar não deveria ter como objetivo prioritário ensinar conteúdos, em vez disso, cumpria-lhe favorecer o desenvolvimento pleno das aptidões individuais, o que tornava imprescindível prover os professores de conhecimentos da psicologia. Nas décadas de 1930 e 1940 essa convicção se fortaleceria a partir da perspectiva da higiene mental, que privilegiava o estudo da influência dos fatores ambientais no (des)ajustamento da criança à escola. Esse foi um período em que, segundo Dante Moreira Leite, diversos intelectuais se propuseram a pensar o Brasil de maneira diferente do modo como o fizeram Sílvio Romero e Nina Rodrigues, seus predecessores, que atribuíam o atraso da cultura brasileira ao fator racial. Em vez disso, autores como Manuel Bomfim, Gilberto Freire, Sérgio Buarque de Holanda, Fernando de Azevedo e outros levaram em conta os aspectos econômicos, sociais e políticos vividos no país em seus estudos dedicados à compreensão da sociedade brasileira (PATTO, 2015).

\section{O Capítulo Escola, psicologia e democracia nos discursos pedagógicos dos anos 1930} e 1940 é dedicado à caracterização das relações que se estabeleceram entre esses termos nos discursos educacionais no período entre as guerras mundiais, quando o ideário da Escola Nova alcançou grande difusão no Brasil. A análise estabelece conexões, no nível dos enunciados, entre o livro Introdução ao Estudo da Escola Nova (1930), de Lourenço Filho; o Manifesto dos Pioneiros da Educação Nova, redigido em 1932 por Fernando de Azevedo e dois artigos de Helena Antipoff. Por meio da caracterização de alguns de seus enunciados recorrentes, propõe uma reflexão sobre a expectativa expressa nesses textos de que a psicologia contribuiria para estabelecer as bases científicas da escola e da sociedade democráticas.

Cumpre observar que esse foi também um período de expansão das vagas nas escolas públicas, motivado pela intensificação da ocupação urbana e da demanda social por educação. Segundo Otaíza Romanelli, houve uma grande ampliação das oportunidades de escolarização já a partir da década de 1920:

\footnotetext{
Enquanto nessa época a taxa de escolarização da faixa de 5 a 19 anos era, praticamente, de $9 \%$ apenas, em 1940, ela já era de 21,43\% e, em 1970, chegou a $53,72 \%$. É evidente a insuficiência dessa expansão, de vez que, em 1970, ainda 46, $28 \%$ da população escolarizável estavam fora da escola. Mas é evidente também o progresso alcançado, desde 1920, quando mais de $90 \%$ da população escolarizável não frequentavam a escola (ROMANELLI, 1998, p. 64).
} 
Muitas crianças que passaram a frequentar a escola pertenciam à primeira geração escolarizada de suas famílias, sem contato prévio com a cultura escolar e, frequentemente, com menores condições de atender às expectativas de comportamento e aprendizado dos professores. É dessa época o surgimento da expressão "criança-problema" no discurso educacional, criada para distinguir as crianças com dificuldades de ajustamento à escola das crianças anormais, categoria que passou a ser reservada àquelas que eram portadoras de deficiências biológicas hereditárias ou congênitas. Passou-se a reconhecer que grande parte das dificuldades enfrentadas pelos alunos na escola não eram devidas à natureza, mas estavam associadas às condições vividas pelas crianças, embora no discurso do período as explicações para as dificuldades dos alunos tenham sido mais frequentemente atribuídas à dinâmica afetiva familiar, interpretadas à luz da psicanálise tal como apropriada pela higiene mental, e raramente associadas às desigualdades sociais ou ao preconceito sofrido nas escolas pelos alunos mais pobres, as crianças negras, os filhos de pais sem escolaridade (PATTO, 2015; LIMA, 2018).

O capítulo A expertise e a techne da psicologia aplicadas à investigação do aluno na escola caracteriza dois exemplos de associação entre técnicas e conhecimentos psi destinados a investigar as dificuldades dos escolares. O primeiro corresponde à psicologia experimental e aos testes para a identificação e a mensuração da inteligência e outros atributos psicológicos, visando à adequação do ensino às necessidades individuais. Afirma-se que a psicologia experimental, ao se aproximar dos métodos das ciências naturais, privilegiou a descrição e a mensuração das capacidades do aluno para estabelecer sua posição em um quadro classificatório. O segundo diz respeito a uma certa apropriação da teoria psicanalítica no tratamento prestado às crianças consideradas problemas em dois serviços de assistência associados às redes de ensino no Rio de Janeiro e em São Paulo, ambos criados na década de 1930, para o atendimento de crianças "desajustadas" à escola. Nesses serviços, à luz da psicanálise, pretendeu-se empreender estudos mais amplos e aprofundados dos alunos considerados difíceis. Passou-se a considerar insuficiente classificá-los por meio da aplicação de testes padronizados, que apenas determinavam o nível de inteligência. Supondo-se que a grande maioria dessas crianças eram dotadas de inteligência normal, às vezes até superior, procurou-se investigar em suas histórias de vida outras causas prováveis dos desajustamentos, levando-se em conta uma miríade de fatores, dentre os quais seu estado de saúde, suas condições materiais de vida, a qualidade dos seus vínculos afetivos na família e na escola e suas motivações, bem como suas fantasias e medos inconscientes. 
As décadas de 1940 e 1960 foram especialmente favoráveis ao estudo da disciplina no meio universitário (CAMPOS et al., 2004). Correspondem ao período em que se iniciaram os cursos de formação em psicologia no Brasil, que permitiram a expansão da pesquisa científica, com ênfase nos estudos sobre os efeitos da cultura na formação da personalidade, de que são exemplos, na Faculdade de Filosofia da Universidade de São Paulo os trabalhos realizados por Anitta Cabral e o canadense Otto Klineberg, que atuou como professor de psicologia visitante na instituição. Na Faculdade de Filosofia da Universidade Federal do Rio de Janeiro, difundiu-se a partir desse período a teoria de Piaget, por iniciativa de Antônio Gomes Penna. A partir de 1960 foram criados os cursos superiores de psicologia no Brasil e posteriormente os cursos de pós-graduação associados à formação de novos grupos de pesquisa, muitos dos quais dedicados aos estudos piagetianos e suas implicações para a educação (CAMPOS et al., 2004b, p. 196). Desde então intensificaram-se os debates em torno das relações entre cultura e desenvolvimento psicológico e o tema do fracasso escolar tornouse um dos principais temas de investigação, a partir da teoria da carência cultural ou de outras perspectivas, que se empenharam em fazer a sua crítica, como foi o caso dos trabalhos realizados a partir do materialismo histórico.

O último capítulo da tese, intitulado "É preciso adaptar o ensino às características do aluno": análise histórica de um enunciado, focaliza um enunciado que expressa um consenso no campo educacional e atravessa os discursos da psicologia difundidos nas escolas normais e cursos superiores de educação desde o início do século XX. A partir do exame de 24 manuais de psicologia para a formação docente, publicados no Brasil entre 1900 e 2014, buscou-se evidenciar que o enunciado em questão se associa à pressuposição da desigualdade das inteligências e à convicção de que o governo dos alunos deve basear-se no conhecimento científico das suas capacidades, de modo a tornar possível o seu pleno desenvolvimento.

Análises contemporâneas sobre a história da psicologia em suas interfaces com a educação caracterizam as décadas de 1980 e 1990 como um período de crise para a disciplina. Nesse período produziram-se no contexto acadêmico uma série de críticas às "práticas discriminatórias e individualizantes no contexto escolar" levadas a efeito por psicólogos escolares, orientados por uma psicologia educacional que associava as dificuldades escolares a deficiências biológicas localizadas no indivíduo e desconsiderava os fatores sociais e escolares relacionados aos problemas vividos pelos alunos nas escolas (BARBOSA, MARINHO-ARAÚJO, 2010, p. 396). Questionou-se o atendimento dos psicólogos às 
demandas escolares por se considerar que, ao contribuir para o ajustamento dos alunos às exigências da instituição, esses profissionais participavam na "reprodução das relações instituídas" que legitimavam a "desumanização do homem, quando seu trabalho reproduz ou mantém a exclusão" (GUZZO et al., 2010, p. 133).

O já clássico estudo A produção do fracasso escolar transformou os modos de pensar as relações entre a psicologia e a educação e desencadeou grande parte das críticas à psicologia escolar no Brasil. A pesquisa empreendida por Maria Helena Souza Patto mostrou como a psicologia participou na naturalização dos chamados problemas de aprendizagem, ao atribuir as dificuldades enfrentadas pelos alunos nas escolas a deficiências individuais ou à inadequação familiar. A autora evidenciou ainda o modo como a psicologia, ao se dedicar a produzir conhecimentos objetivos sobre os alunos e suas capacidades, por meio da elaboração de testes para a mensuração da inteligência e de outros tipos de avaliação, passou a atribuir status de verdade à desqualificação dos alunos que não se saíam bem na escola e em tais procedimentos diagnósticos. Esses alunos, majoritariamente pertencentes a camadas mais desfavorecidas da população, eram avaliados por especialistas que ocupavam posições sociais privilegiadas e que apresentavam uma série de preconceitos em relação às crianças pobres e aos modos de vida de suas famílias. Suas concepções se refletiam na produção de testes e inquéritos por meio dos quais os maus alunos eram avaliados e, quase sempre, julgados como incapazes ou imorais. A partir do recurso à psicologia, o fracasso escolar foi sistematicamente explicado como consequência da incapacidade biológica da criança ou da incompetência de sua família, desconsiderando-se a possibilidade de participação da própria escola na produção de entraves no aprendizado (PATTO, 2015). Em outro trabalho, a autora denunciava:

\footnotetext{
As práticas de diagnóstico de alunos encaminhados por escolas públicas situadas em bairros pobres constituem verdadeiros crimes de lesa-cidadania: laudos sem um mínimo de bom senso e de senso de ridículo produzem estigmas e justificam a exclusão escolar de quase todos os examinados, reduzidos a coisas portadoras de defeitos de funcionamento em algum componente da máquina psíquica (PATTO, 2000, p. 67).
}

As críticas desse período aos discursos da psicologia que produziam a desqualificação dos alunos atingiram também os professores. Passou-se a denunciar a precariedade da formação docente, em especial a ausência de uma perspectiva crítica nas disciplinas dos cursos de pedagogia e licenciatura, que levasse os professores em formação a compreender as condições históricas, sociais e políticas associadas às dificuldades enfrentadas pelas crianças em seu processo de escolarização. De acordo com uma série de pesquisas sobre o fracasso escolar 
realizadas em escolas públicas primárias, o problema se evidenciava na incapacidade das professoras de propor aulas e atividades adequadas à compreensão e ao interesse dos alunos; na sua indisponibilidade para considerar as individualidades, nos seus preconceitos em relação às crianças cuja aparência e comportamento se afastava da criança típica de classe média, especialmente as pobres e negras, e também no autoritarismo com que procuravam impor a disciplina na sala de aula, desconsiderando as necessidades de movimentação e expressão verbal própria das crianças. Constatou-se que

\begin{abstract}
Frequentemente são encaminhadas crianças cuja queixa é imaturidade, indisciplina, desobediência. Elas não correspondem à expectativa da instituição escolar, não apresentam os comportamentos esperados pela professora, como ficar sentado, quieto, fazendo as lições e obedecendo ordens. São geralmente crianças normais, apresentando uma gama diversa de comportamentos esperados para a idade e outras vezes reativo a situações de ensino aborrecidas e/ou desrespeitosas. Cabe à escola entender esses comportamentos e educar, no sentido de permitir seu acesso à cultura e não no sentido de moralizar e domesticar (FRELLER, 2004, p. 74).
\end{abstract}

Os estudos sobre o fracasso escolar no Brasil passaram a incluir como objeto central de investigação a "queixa escolar", entendida como "pedido de ajuda" da escola dirigido aos psicólogos. Pesquisas levadas a efeito em escolas e serviços de psicologia dedicados ao atendimento de crianças procuraram esclarecer questões como "quais são os chamados problemas de aprendizagem? Quais são as atitudes da criança em sala de aula que são motivos de encaminhamento psicológico? Como são qualificados pelos educadores? " (SOUZA, 2000, p. 137). Análises críticas das descrições das crianças-problemas feitas por suas professoras foram contrapostas à percepção de psicólogas que, em suas pesquisas, dedicaram-se a conhecer as crianças individualmente, sem submetê-las às avaliações e às normas estabelecidas pela escola. E o que essas pesquisas constatavam era que quase sempre as crianças caracterizadas na escola como apáticas, indisciplinadas ou deficientes mostravam-se curiosas, inteligentes, sensíveis e criativas nas suas interações com as psicólogas (SOUZA et al, 1989; MOYSÉS \& COLLARES, 1995; MACHADO \& SOUZA, 2004; PATTO, 2015). Na mesma direção, as pesquisas empreendidas por Cecília Collares e Maria Aparecida Moysés acerca dos discursos de professores, médicos, psicólogos e outros especialistas sobre as crianças com baixo desempenho escolar dedicaram-se a evidenciar que elas eram avaliadas exclusivamente por suas "faltas", por aquilo que não sabiam e não conseguiam fazer na escola, enquanto sistematicamente se desconsiderava o que elas sabiam fazer e os conhecimentos que possuíam, como expressão de seu potencial cognitivo (MOYSÉS \& COLLARES, 1997). 
Outras críticas à psicologia educacional se fizeram a partir do recurso à psicanálise, endereçadas principalmente à sua pretensão de assegurar cientificamente a eficácia do ato pedagógico adequado ao desenvolvimento do aluno e ao processo de desautorização dos professores em face dos alunos. Como se procurou argumentar, o processo de "psicologização da pedagoga" produziu nos pais e professores uma tendência à renúncia ao exercício da autoridade e à própria educação, uma vez que eles passaram a temer afrontar a natureza da criança e, assim, prejudicar o seu desenvolvimento. Passaram então a evitar tomar qualquer decisão sem recorrer aos especialistas psi, de quem se esperavam todas as respostas e garantias sobre "como funciona" o aluno e "como ensinar". Para Lajonquière (1998, p. 126-127),

\begin{abstract}
A pedagogia moderna nas suas diversas versões está sempre centrada no aluno. Assim como Rogers inventou a psicologia ou terapia centrada no cliente, a pedagogia hoje condena o cotidiano escolar a girar em falso quando de seu centramento nas capacidades psicomaturacionais. Por sinal, a crítica a esse suposto centramento no aluno não significa endossarmos o furor pedagógico de outrora, mas apenas assinalar que o interesse em ajustar a intervenção a um suposto estado natural das capacidades dos escolares implica a renúncia ao ato. Isto é, implica a demissão do adulto da posição do educador.
\end{abstract}

No início do século XXI, reflexões como as precedentes levaram diversos pesquisadores a defenderem a transformação dos modos de intervenção dos psicólogos na escola. No âmbito das investigações dedicadas à análise crítica das relações entre psicologia e educação escolar surgiram recomendações para que esses profissionais, em vez de se dedicarem ao diagnóstico e à remediação de problemas localizados no aluno, deveriam criar espaços de escuta para os integrantes da equipe escolar. Os psicólogos passariam então a mediar rodas de conversa nas quais os profissionais pudessem se ouvir e refletir sobre as situações vividas no cotidiano e sobre as relações institucionais, de modo a favorecer a realização de mudanças por iniciativa dos próprios sujeitos envolvidos. (BARBOSA; MARINHO-ARAÚJO, 2010, p. 398; SOUZA et al., 2014).

Paralelamente, outro conjunto de trabalhos, ao qual se acrescenta esta pesquisa, dedicou-se ao exame de vários investimentos da psicologia sobre a educação escolar e seus efeitos nos discursos e práticas pedagógicas contemporâneas a partir da perspectiva de uma história crítica. Alguns desses estudos, valendo-se também da perspectiva foucaultiana, evidenciaram os modos de produção discursiva e institucional do aluno como um indivíduo dotado de (in)capacidades determinadas pela biologia e/ou pelo ambiente em que vive, um indivíduo em desenvolvimento, cujo futuro é possível prever e governar por meio de intervenções educativas e/ou terapêuticas. Analisaram ainda os processos de normalização dos 
comportamentos, cuja contraface foi a patologização das manifestações não conformes às suas exigências. ${ }^{4}$ Mostraram tais processos em funcionamento não apenas nas escolas tradicionais, mas também nas alternativas e renovadas sob a influência das teorias psicológicas, nas quais o controle, em vez de suprimir as liberdades, procura empregá-las para promover o desenvolvimento desejado, de modo que esse desenvolvimento é menos "natural" do que artificialmente produzido pelas práticas pedagógicas postas em funcionamento na escola ativa. Como sustenta Valerie Walkerdine (1998, p. 155), “a Psicologia do Desenvolvimento e a pedagogia centrada-na-criança formam um par: os aparatos da pedagogia não são uma mera aplicação mas um local de produção de direito próprio”.

Nem mesmo os discursos que se propuseram a formular a renovação da psicologia escolar a partir da perspectiva da crítica social foram poupados por essas análises, que encontraram nessas propostas outras tentativas de colonização da escola tendo em vista objetivos alheios à sua especificidade. Exemplo disso encontra-se no texto "O controverso lugar da psicologia na educação: aportes para a crítica da noção de sujeito psico-pedagógico", em que se constata:

E dois são os modos dominantes como tal investida habitualmente se perfaz: de um lado, a psicologia educacional, munida de um arsenal de conceitos alegadamente científicos, os quais pretendem descrever os processos de aquisição cognitiva e, assim, qualificar a ação do docente, auxiliando-o a se aperfeiçoar/atualizar tecnicamente; de outro lado, a psicologia escolar, mormente de orientação crítica, munida de um arsenal de conceitos sensivelmente distintos daqueles da vertente anterior, mas ainda disposta a auxiliar o educador a ampliar suas competências, agora por meio do esclarecimento acerca dos processos políticos subjacentes aos procedimentos pedagógicos tradicionais (AQUINO, 2014, p. 6).

Ao tornar-se professora de Psicologia no Instituto Caetano de Campos, Noemy da Silveira Rudolfer, sucessora de Lourenço Filho na cátedra, sentiu-se desorientada diante da dispersão dos pontos de vista na psicologia e da diversidade de escolas que a caracterizava. Dedicou-se então a compreender a evolução histórica da disciplina. Seu livro Introdução à

\footnotetext{
${ }^{4}$ Entre muitas outras referências, pode-se citar: Moysés \&Collares, 1997; Silva, 1998; Walkerdine, 1998; Varella, 1999; Ó, 2003; Aquino, 2009, 2014; Popkewitz, 2015; Bautheney, 2018; Lima, 2018.
} 
psicologia educacional, publicado pela primeira vez em 1938, é resultado de seus investimentos nessa direção e, no período em que foi publicado, constituiu uma proposta original para o estudo da psicologia e suas contribuições para a educação. A autora concluiu que a melhor alternativa para o ensino da matéria era a adoção de um "ponto de vista eclético" e afirmou que fora o método científico e seu aperfeiçoamento ao longo do tempo que promovera os maiores avanços da psicologia educacional.

Este trabalho tem como ponto de partida uma motivação análoga, relativa às minhas próprias indagações como professora da disciplina e responsável por seu ensino a professores em formação. Afirmei anteriormente que, no decorrer do século XX, a psicologia tornou-se uma disciplina especialmente valorizada entre as ciências da educação, depositária de grandes expectativas quanto à sua contribuição, assim como passou a ser objeto de duras críticas ao final desse período. Contudo, em vez de ensejar a extinção da matéria nos cursos de formação docente, o que ocorreu em certos casos foi que o ensino da disciplina passou a ser realizado a partir de diferentes perspectivas críticas, com as quais tomei contato pela primeira vez no curso de pedagogia da Universidade de São Paulo, onde realizei meus estudos de graduação. Em várias disciplinas os temas das dificuldades de aprendizagem e da indisciplina do aluno eram problematizados, referidos a um contexto social e aos modos de funcionamento da escola, desafiando-se assim a concepção do senso comum de que se tratava de problemas individuais dos alunos. Ao ingressar na iniciação científica e posteriormente no mestrado, dediquei-me ao estudo do tema da indisciplina escolar e tomei contato com a obra de Foucault, que se tornou uma referência fundamental nas investigações posteriores sobre surgimento da expressão "criança-problema" no discurso educacional e sobre a educação científica das mães, tal como configurada nos manuais de puericultura. As considerações sobre a análise de discurso formuladas pelo autor constituíram uma fonte de inspiração desde a realização desses trabalhos anteriores.

Da perspectiva teórica a partir da qual me pronuncio, ao tomar como objeto de investigação os discursos da psicologia divulgado no campo da educação, não caberia propor uma atualização ou retificação da evolução histórica da psicologia educacional, nem apresentar suas novas ou melhores aplicações possíveis. Em vez disso, procurei caracterizar alguns aspectos relevantes dos discursos da psicologia educacional transmitidos aos professores no decorrer do século $\mathrm{XX}$, buscando identificar as recorrências e as transformações em suas verdades e prescrições para a educação escolar. Cuidei de explicitar o modo como foram enunciadas as expectativas sobre suas contribuições para a educação escolar; as verdades 
produzidas sobre os alunos, suas capacidades, seu desenvolvimento, suas dificuldades e ainda as orientações derivadas dessas verdades para a prática docente e a organização do trabalho na escola. Em termos foucaultianos, pretendi verificar os modos de articulação entre saber e poder na interface entre a psicologia e a educação.

Mais do que as considerações que pude tecer sobre os discursos da psicologia educacional nas práticas institucionalizadas e nas recomendações ofertadas aos professores, espero que os textos que compõem este trabalho interessem pelos exemplos de análises que apresentam. Sem a intenção de propor uma alternativa para a psicologia educacional, enfim livre de perigos e coerções, como se fosse possível viver fora do discurso, talvez essas análises permitam abrir algumas fendas em nosso regime de verdades psicológicas sobre os alunos e a sua escolarização e contribuir para a identificação de certos perigos, quiçá evitáveis, e certas coerções, quem sabe desnecessárias. 


\title{
1. A "VONTADE DE PSICOLOGIA" COMO VONTADE DE VERDADE E DE PODER NA FORMAÇÃO DOS PROFESSORES
}

\begin{abstract}
Separação historicamente constituída, com certeza. Porque, ainda nos poetas gregos do século VI, o discurso verdadeiro - no sentido forte e valorizado do termo -, o discurso verdadeiro pelo qual se tinha respeito e terror, aquele ao qual era preciso submeter-se, porque ele reinava, era o discurso pronunciado por quem de direito e conforme o ritual requerido; era o discurso que pronunciava a justiça e atribuía a cada qual sua parte; era o discurso que, profetizando o futuro, não somente anunciava o que se ia passar, mas contribuía para sua realização, suscitava a adesão dos homens e se tramava assim com o destino. Ora, eis que um século mais tarde, a verdade a mais elevada já não residia mais no que era o discurso, ou no que ele fazia, mas residia no que ele dizia: chegou um dia em que a verdade se deslocou do ato ritualizado, eficaz e justo, de enunciação, para o próprio enunciado: para seu sentido, sua forma, seu objeto, sua relação a sua referência (FOUCAULT, 2010, p. 15, destaques do autor).
\end{abstract}

Como se articularam vontade de verdade e vontade de poder nos discursos que se situam na interface entre a psicologia e a educação? Este capítulo investiga a questão a partir do exame de textos escritos por e para professores nas décadas de 1930 e 1940, período de grande difusão do ideário da Escola Nova no Brasil. A fonte nuclear da análise corresponde a um conjunto de manuais de psicologia educacional que permitem evidenciar a articulação entre os conhecimentos da psicologia sobre a criança e as recomendações sobre como favorecer o aprendizado dos alunos.

Busca-se evidenciar que, ao lado da valorização da psicologia, considerada no período como a fundamentação científica da educação escolar, encontram-se nesses mesmos textos dúvidas e críticas relativas aos seus saberes, seus modos de elaboração e sua capacidade de solucionar as dificuldades e superar os problemas vividos nas escolas. A psicologia transmitida aos professores não constituiu um discurso coeso e coerente, mas caracterizou-se pela heterogeneidade e dispersão dos temas, teorias, autores de referência e modos de apresentação da matéria. As mesmas questões que se procurou responder por meio do recurso aos métodos de estudo e aos conhecimentos científicos então disponíveis - por exemplo, a investigação do mau rendimento do aluno na escola por meio do recurso aos testes de inteligência, seguida da constatação de sua deficiência mental - levaram em seguida à formulação de outras perguntas, 
hipóteses explicativas e recomendações, bem como à elaboração de críticas dirigidas tanto aos procedimentos empregados nas pesquisas quanto à interpretação dos seus resultados. Os testes foram celebrados como recurso privilegiado para a descoberta da verdade sobre as aptidões individuais, mas também foram alvo de desconfiança e de crítica por parte dos psicólogos dedicados ao estudo dos problemas relativos à educação escolar. Em meio à série monótona de enunciados recorrentes que fizeram a defesa da psicologia como fundamento científico imprescindível à pedagogia, apareceram enunciados esparsos que evidenciam a presença, ainda que mais discreta, da dúvida e da crítica no interior da disciplina. Assim, além da caracterização da psicologia e suas implicações para a escolarização das crianças, importa tornar visíveis também os questionamentos produzidos no interior do próprio discurso, os quais, muitas vezes puseram em dúvida seus pressupostos e aplicações mais perversos, como aqueles decorrentes do determinismo biológico, pelo qual se afirmava a incapacidade mental dos alunos que não se saíam bem na escola e se recomendava a sua exclusão das classes regulares, sem considerar suas condições de vida e as da escola que frequentavam.

Inicialmente, recorre-se a textos de Foucault e outros autores contemporâneos sobre a análise do discurso, concentrando-se sobre o tema da vontade de verdade e sua importância na cultura ocidental. Adiante, procura-se caracterizar a presença da psicologia do domínio da educação. O primeiro texto examinado é o Manifesto dos Pioneiros da Educação Nova, publicado em 1932. Nesse documento, que é considerado um divisor de águas no campo educacional, vê-se com clareza como a vontade de poder transformar as escolas com vistas à modernização do país vinculava-se à vontade de verdade sobre as crianças, suas necessidades e seus interesses. Em seguida, analisam-se livros e artigos de professores das escolas normais e cursos superiores de formação docente de São Paulo, Rio de Janeiro e Minas Gerais que se dedicaram à divulgação da psicologia entre os professores.

A análise mostra que a aproximação entre a psicologia e a educação produziu um deslocamento fundamental na articulação entre verdade e poder na educação. Tradicionalmente, a verdade e o poder em sala de aula estavam vinculados à autoridade do professor, a qual se sustentava em seus conhecimentos e sua experiência de vida, que faltavam ao aluno. Sua palavra era reconhecida como verdadeira e eficaz, cabia a ele distinguir o certo e o errado e determinar o que deveria acontecer. Com a disseminação da psicologia no campo educacional, a verdade deslocou-se do discurso do professor para os discursos da psicologia da criança, que ele então foi instado a aprender e a obedecer, para que o seu ensino atingisse seus 
objetivos. Desde então a verdade deixou de se sustentar na autoridade do mestre. Em vez disso, a autoridade do mestre precisou se apoiar na verdade da psicologia para ter legitimidade e eficácia.

Em suas investigações, Foucault não tomou o sujeito como origem ou fonte da verdade, mas interessou-se pelas condições históricas associadas à produção da verdade. Podese dizer que se dedicou a uma história crítica da verdade, pois buscou explicitar como se formaram em diferentes períodos, os discursos que se disseminaram como sendo verdadeiros, procurando identificar as regras de sua formação. Para o autor, o sujeito e o objeto não são preexistentes, mas efeitos de práticas históricas raras, uma vez que formadas a partir de uma combinação irrepetível de circunstâncias. A própria relação do sujeito com a verdade é mutável:

Para Michel Foucault, aquilo que denominamos 'verdade' não possui um significado unívoco sendo, antes, um jogo histórico, uma enunciação dramática: ela pode ser o mecanismo do qual dispomos para preencher o vazio que constitui nosso pensamento finito, ou a justificação racional que elaboramos para compreender nossas práticas cotidianas, ou ainda o escudo protetor que adquirimos diante das vicissitudes que nos ameaçam. Contudo, o que entendemos por 'verdade' pode estar associado também a riscos que assumimos, a resistências que sustentamos, ao êthos filosófico que incorporamos mediante a crítica de nosso ser histórico (CANDIOTTO, 2006, p. 73).

$\mathrm{Na}$ aula inaugural que proferiu no Collège de France, Foucault examinou a forma da vontade de verdade que caracteriza a ordem do discurso em que estamos inseridos e observou que ela tem a sua própria história e apoia-se em suportes institucionais. Chamou atenção para o modo como a produção do conhecimento científico está ligada à organização das universidades, das bibliotecas e dos laboratórios e seus procedimentos específicos - planos de estudos, práticas de leitura, modos de se aproximar dos objetos, de os ver, ordenar, medir e classificar etc. Argumentou que a compreensão das transformações nos modos de produção da verdade exige levar em conta essas organizações, bem como considerar os modos pelos quais se pretende aplicar os saberes aí produzidos nas instituições sociais e as formas de valorização e divulgação desses conhecimentos na sociedade. Acrescentou que importa verificar ainda as formas de atribuição do saber, ou seja, os modos pelos quais certas pessoas, pela sua posição social ou institucional são autorizadas a formular o discurso verdadeiro, enquanto outras estão apenas em condição de se apropriar de suas verdades ou de submeter-se a elas.

Segundo o autor, quando se examina uma proposição no interior de um discurso, "a separação entre o verdadeiro e o falso não é nem arbitrária, nem modificável, nem institucional, 
nem violenta" (FOUCAULT, 2010, p. 14). No entanto, se nos situamos em outro nível e procuramos esclarecer como se formou a vontade de verdade que caracteriza esse discurso, vemos então delinear-se um sistema histórico de exclusão. O discurso que não tem uma base de verdade (científica), que não pode ser comprovado por meio da observação controlada, da experiência, do recurso a testemunhas ou dados estatísticos é excluído do verdadeiro. Ele observa que para ser considerado verdadeiro, para estar de acordo com a nossa vontade de verdade, o discurso precisa dissociar-se do desejo e do poder. No entanto, apenas o que consegue é mascará-los, pois é devido à vontade de verdade, que o discurso verdadeiro adquire primazia. E seu privilégio decorre da exclusão, num ato de poder, dos discursos não conformes ao modo reconhecido de produção da verdade.

Foucault considerou ainda que, embora a vontade de verdade tenha se intensificado, tornando-se a forma mais importante de controle dos discursos na nossa sociedade, quase não se fala dela, como se ela não existisse, como se fosse uma evidência indiscutível que nossos discursos e práticas devessem estar submetidos à verdade. Como se fosse evidente que tudo o que falamos e fazemos devesse ser justificado por um discurso verdadeiro, uma vez que até mesmo a escrita dos romances e o sistema penal passaram a se apoiar no discurso científico, para atender à nossa particular vontade de verdade, "como se a própria palavra da lei não pudesse mais ser autorizada, em nossa sociedade, senão por um discurso de verdade" (FOUCAULT, 2010, p. 19). O autor dedicou-se especialmente ao estudo das relações que se estabeleceram nas sociedades ocidentais "entre a individualidade, o discurso, a verdade e a coerção". Em uma conferência intitulada "Verdade e subjetividade", proferida em Berkeley no ano de 1980, ele afirmou que o estudo dos conhecimentos produzidos no âmbito das ciências humanas foi estratégico para o seu projeto de realizar uma genealogia do sujeito moderno:

Todas as práticas pelas quais o sujeito é definido e transformado são acompanhadas pela formação de certos tipos de conhecimento e, no Ocidente, por uma variedade de razões, o conhecimento tende a ser organizado em torno de formas científicas. Há também uma outra razão talvez mais fundamental e mais específica das nossas sociedades. Reside no fato de que uma das mais importantes obrigações morais ser, para qualquer sujeito, o conhecer-se a si próprio. A obrigação dos indivíduos à verdade e uma organização científica do conhecimento são as duas razões pelas quais a história do conhecimento constitui um ponto de vista privilegiado para a genealogia do sujeito (FOUCAULT, 1993, p. 205)

Analogamente, pode-se considerar que uma história do conhecimento da psicologia produzido e difundido no domínio educacional pode proporcionar uma perspectiva fértil para a genealogia do aluno. $\mathrm{O}$ exame dos textos pedagógicos que tratam de suas contribuições para 
a educação escolar permite identificar um deslocamento da verdade do discurso do professor para os discursos da psicologia da criança. No domínio pedagógico, a verdade mais valorizada passou a ser a verdade da psicologia sobre o aluno que os professores deveriam conhecer. A exigência fundamental não era que os professores conhecessem as verdades relativas ao conteúdo que deveriam lecionar ou a verdade sobre si próprios, mas que conhecessem a verdade sobre a criança e o seu desenvolvimento. Esse deslocamento evidenciou-se mais claramente no âmbito do movimento da Escola Nova. Segundo seus representantes, o discurso do professor, que na escola tradicional era sustentado por sua autoridade e admitido como verdadeiro pelos alunos, esse discurso que era preciso aprender e às vezes decorar deveria, na escola moderna, subordinar-se aos saberes da psicologia. Daí em diante, as verdades mais valiosas e às quais o professor precisava submeter-se passavam a ser as que a psicologia descobria sobre a criança. Parafraseando Foucault, poder-se-ia dizer que a verdade primordial deslocou-se dos saberes transmitidos pelo mestre à natureza psicológica da infância, como se o seu saber não pudesse mais ser autorizado na escola se não estivesse conforme ao discurso verdadeiro sobre a criança, suas aptidões, seus interesses, seu aprendizado.

Um aspecto importante da análise empreendida por Foucault consiste em sua opção por privilegiar o caráter de acontecimento dos discursos. Para ele não importava tanto saber se um determinado enunciado correspondia ou não à verdade, mas, a partir da constatação de que foi formulado, compreender como pôde aparecer, a partir de que outros enunciados precedentes e obedecendo a que regras de formulação. Suas análises renunciaram também à investigação das motivações não declaradas dos autores, mas atinham-se ao conteúdo expresso nos discursos e seus efeitos na proliferação dos enunciados e sua articulação com conjuntos de práticas. Aproximando-se dessa perspectiva, esta análise dedica-se a evidenciar as regularidades no modo como diferentes autores se pronunciaram acerca do tema, sem desconsiderar as diferenças dignas de nota e as formulações discordantes, de modo a caracterizar a dispersão dos enunciados no âmbito dessa formação discursiva. 


\title{
1.1 Vontade de verdade e de poder no ensino da psicologia aos professores brasileiros
}

\begin{abstract}
(...) se os problemas de educação devem ser resolvidos de maneira científica, e se a ciência não tem pátria, nem varia, nos seus princípios, com os climas e as latitudes, a obra de educação deve ter, em toda a parte, uma 'unidade fundamental', dentro da variedade de sistemas resultantes da adaptação a novos ambientes dessas ideias e aspirações que, sendo estruturalmente científicas e humanas, têm um caráter universal (MANIFESTO DOS PIONEIROS DA EDUCAÇÃO NOVA, 1932/ 2010, p. 63).
\end{abstract}

Em 1932 foi divulgado o Manifesto dos Pioneiros da Educação Nova, dirigido ao povo e ao governo com o objetivo de apresentar um diagnóstico e um plano para a educação nacional. O Manifesto constitui um marco no discurso educacional brasileiro e expressa tanto as expectativas depositadas pelos intelectuais da época na educação como recurso para o desenvolvimento do país, quanto suas preocupações relativas às condições de funcionamento do sistema de ensino no Brasil. Resulta do conjunto de iniciativas levadas a efeito na década de 1920, quando a educação deixou de ser discutida por grupos restritos e passou a ser mais amplamente percebida como um problema nacional. Entre os acontecimentos marcantes para a educação nacional ocorridos nesse período e que culminaram na produção do Manifesto dos Pioneiros deve-se considerar a criação da Associação Brasileira de Educação (ABE) no ano de 1924, instituição na qual se reuniram os educadores mais influentes da época e que promoveu uma série de conferências nacionais de educação. De acordo com Paschoal Lemme (2005), a iniciativa de redigir um documento que sistematizasse um conjunto de diretrizes para a educação nacional a partir de uma análise dos seus principais problemas surgiu na quarta conferência, que contou com o apoio de Getúlio Vargas, então chefe do governo revolucionário provisório, e pretendeu guiar a atuação do recém-criado Ministério da Educação e da Saúde. Os signatários do Manifesto parecem ter visto na mudança de governo a oportunidade de inauguração oficial da Escola Nova brasileira. Trataram então de marcar sua diferença em relação à escola tradicional do Império, cujo funcionamento não fora superado na Primeira República. Estabeleceram como princípios norteadores da renovação do sistema de ensino a escola única, pública, laica, gratuita e obrigatória para ambos os sexos. Ao pretender implementá-los nos sistemas públicos de ensino, precisaram travar uma disputa com os educadores católicos, para os quais o privilégio de financiamento concedido pelo governo à escola pública e laica consistia em uma restrição à liberdade das famílias de escolher para os seus filhos outras modalidades de ensino, inclusive o confessional (VIDAL, 2013). 
Na introdução ao Manifesto, Fernando de Azevedo, então professor de sociologia no Curso de Aperfeiçoamento do Instituto Pedagógico de São Paulo, apresentava um conjunto de reflexões sobre as rápidas mudanças sociais associadas ao progresso da ciência e da técnica, que pareciam ultrapassar a capacidade dos homens de acompanhá-las. Entendia que essa sensação era ainda mais intensa no Brasil, devido à falta de disciplina mental e social que caracterizava a população, agravada pela ausência de uma cultura universitária. A produção intelectual brasileira, sobretudo relativa aos temas políticos e sociais caracterizava-se, segundo o autor, por sua "incoerência", "superficialidade" e "flutuação", efeitos da "indisciplina mental" (AZEVEDO, 1932, p. 18) . Havia ainda a considerar a dispersão do povo pelo território e sua composição heterogênea, que dificultava ainda mais a formação de modos de vida e valores comuns. Participava na determinação do atraso cultural do país a formação escolar de seus intelectuais, que era tradicional, estritamente literária e individualista, alheia à realidade e aos problemas sociais. Urgia, pois, uma verdadeira renovação da cultura nacional por meio da escola, tendo em vista adaptá-la às transformações sociais determinadas pelos avanços da ciência e da técnica e pela necessidade de promover os ideais de solidariedade e cooperação entre os grupos sociais, em oposição à defesa dos interesses individuais e de classe.

A ênfase conferida às ciências na determinação das transformações sociais que se verificavam era importante, e seus efeitos se faziam sentir no domínio da educação escolar, que deveria ter orientação científica, uma vez que "o homem, criando e desenvolvendo 'o meio artificial', consegue dominar com ele, 'o mundo natural', que lhe é hostil, subordinando-o às suas necessidades e aspirações” (MANIFESTO, 1932/2010, p. 27-28). Mas a influência da ciência estendia-se a outras áreas, à filosofia, à política. Conforme o texto "a própria filosofia que nos inspirar deve ser científica, isto é, uma filosofia que buscar as verdades, com o espírito e os métodos da ciência" (MANIFESTO, 1932/ 2010, p. 15). Ressaltava-se ainda que se vivia "numa época em que se acentua por toda a parte a intervenção da ciência na direção dos negócios públicos, entregues até então ao instinto dos povos e ao capricho dos governos" (MANIFESTO, 1932/2010, p. 17).

O texto do Manifesto acusava a desorganização do sistema de ensino no país, que se caracterizava pela dispersão e a descontinuidade das iniciativas. Essa situação era relacionada à falta de clareza quanto aos fins da educação, o que indicava a carência de espírito filosófico e ausência da aplicação do método científico no enfrentamento dos problemas. 
Quanto à finalidade, partia-se da constatação de que a tarefa educativa jamais se destinara ao desenvolvimento de todas ou quaisquer faculdades nos indivíduos. Em vez disso, os educadores sempre haviam buscado promover nas crianças as qualidades que correspondiam a um ideal de homem, variável em função do tempo e do espaço, de modo que os objetivos pedagógicos eram definidos pelo espírito da época e do lugar. Segundo o Manifesto a finalidade da educação nova não deveria ser a manutenção da velha ordem social e econômica por meio das práticas de ensino tradicionais, artificiais e verbalistas, mas devia assumir uma feição "biológica", o que significava reconhecer "a todo indivíduo o direito a ser educado até onde o permitam suas aptidões naturais, independente de razões de ordem econômica e social" (MANIFESTO, 1932/ 2010, p. 40).

Afirmava-se que, graças ao desenvolvimento das ciências pedagógicas, tornara-se possível perseguir os fins da educação a partir de meios adequados. A Escola Nova, onde se praticava a "verdadeira educação funcional” já não se concebia como acréscimo de conteúdos à mente do aluno, como antes, mas como crescimento do espírito do aluno de dentro para fora, motivado pelos seus próprios interesses e atividade espontânea, que passavam a ser os eixos em torno dos quais se organizava o trabalho escolar. Em vez das "tendências exclusivamente passivas, intelectualistas e verbalistas da escola tradicional", a Escola Nova apostava na "atividade espontânea, alegre e fecunda, dirigida à satisfação das necessidades do próprio indivíduo" (MANIFESTO, 1932/ 2010, p. 49). A novos fins deveriam corresponder novos meios, o que implicava na modificação dos currículos em função dos saberes da psicologia sobre o desenvolvimento da criança:

É certo que, deslocando-se, por esta forma, para a criança e para seus interesses, móveis e transitórios, a fonte de inspiração das atividades escolares, quebra-se a ordem que apresentavam os programas tradicionais do ponto de vista da lógica formal dos adultos, para os pôr de acordo com a 'lógica psicológica', isto é, com a lógica que se baseia na natureza e no funcionamento do espírito infantil (MANIFESTO, 1932/ 2010, p. 50-51).

$\mathrm{Na}$ Escola Nova, as atividades orientavam-se no sentido dos interesses da criança, da realidade do trabalho e da vida social. Tratava-se de respeitar as individualidades, de desenvolver ao máximo as aptidões naturais de cada um, de modo que todos viessem oferecer suas melhores contribuições à sociedade. Substituía-se a organização "formal e rígida" da escola tradicional pela organização natural e conforme à vida em sociedade. Em suma, visavase ao ajustamento científico do indivíduo em desenvolvimento ao meio social. 
Entre os signatários do Manifesto estavam Sampaio Dória (1883-1964), Lourenço Filho (1897-1970) e Noemy Rudolfer (1902-1988), professores que se sucederam no ensino da psicologia educacional na Escola Normal da Praça, inaugurada em São Paulo em 1894, no âmbito da reforma do ensino empreendida por Caetano de Campos. Os três escreveram livros para o ensino da matéria a partir de suas experiências. Lourenço Filho foi aluno de Sampaio Dória, a quem dedicou Introdução ao Estudo da Escola Nova (1930) e professor de Noemy Rudolfer que, por sua vez, dedicou-lhe sua obra Introdução à Psicologia Educacional (1961).

Sampaio Dória formou-se na Faculdade de Direito de São Paulo na primeira década do século XX, quando também começou a lecionar Psicologia e Lógica no antigo Ginásio Macedo Soares. Ingressou na Escola Normal de São Paulo em 1914, quando se instalou ali o Gabinete de Antropologia Pedagógica e Psicologia Experimental (TAVARES, 1996; MONARCHA, 1999). Os livros Psychologia (1926) e Educação (1933) são frutos do trabalho realizado pelo autor como professor da disciplina Psicologia, Pedagogia e Educação Cívica na Escola Normal, função em que permaneceu até 1925, quando foi sucedido na instituição por Lourenço Filho (ANTUNES, 2001).

$\mathrm{Na}$ ocasião de seu ingresso como professor da cátedra de psicologia, pedagogia e educação cívica na Escola Normal de São Paulo, Sampaio Dória apresentara a tese Princípios de Pedagogia (1914). Defendera aí que os dois principais problemas da educação diziam respeito à determinação das matérias que comporiam os programas e, em seguida, ao esclarecimento do modo como os conteúdos estabelecidos seriam ensinados. Mencionava rapidamente diversas questões relacionadas aos programas para depois passar a uma discussão mais extensa acerca dos métodos de ensino. Iniciava pela afirmação de que eram necessárias algumas qualidades psicológicas inatas ao bom professor, como a tendência a compreender os alunos e suas dificuldades. Em suas palavras: "pela convergência de certos pendores hereditários, o homem pode ter, em grau acentuado, esse dom natural de ensinar, todo feito de paciência, de simpatia persuasiva, de generosidade, de piedade para os com retardios, os humildes das aulas, os obtusos, inconstantes, deslocados" (DÓRIA apud CARVALHO, 2010, p. 125). Mas, à vocação natural era preciso acrescentar o estudo, o preparo científico, especialmente em matéria de psicologia infantil.

Psychologia (1926), do mesmo autor, é um tratado de psicologia geral cujo conteúdo inclui uma apresentação da disciplina, sua definição e métodos e contempla os seguintes temas gerais: estados da consciência, sensações, atividade do cérebro, hábito, estados afetivos e 
representativos, linguagem, percepção, imaginação, raciocínio, conhecimento e verdade, atenção, memória, vontade, caráter. Embora destinado à formação de professores na Escola Normal, o livro não faz qualquer referência aos problemas de aprendizagem, nem sequer à escola. Não se trata aí da criança ou do aluno, nem do anormal. Trata-se do sujeito psicológico, o homem genérico e sua consciência. Segundo a definição apresentada pelo professor: "A psicologia é um sistema de verdades sobre os estados de consciência” (DÓRIA, 1926, p. 5). De acordo com o discurso vigente nas obras do gênero à época, o professor explicava:

\begin{abstract}
A psychologia, como sciencia autônoma, é de organização relativamente recente. Sem dúvida os problemas psicológicos mais sérios já foram ventilados pelos filósofos antigos, e pelos curiosos de todos os tempos. Nas obras dos moralistas, dos oradores, dos romancistas, dos historiadores, há observações psicológicas, numerosas e valiosas, de verdades inequívocas. Sempre o homem conheceu, embora empiricamente, verdades incontestáveis sobre os seus estados de consciência. Mas, como estudo sistemático, e como disciplina autônoma, a psicologia começa a se precisar no século XVIII. Nestas últimas décadas, o seu desenvolvimento vem sendo espantoso. Revistas eruditas, obras de tomo e laboratórios complexos, se têm multiplicado, no intuito de desprender a psicologia da filosofia, de não a confundir com a fisiologia, de desgarrá-la da sociologia, de constituí-la, em suma, ciência própria e desenvolvida, como hoje a física (DÓRIA, 1926, p. 5).
\end{abstract}

Do mesmo autor, o livro Educação, de 1933, também registra as lições proferidas pelo autor na Escola Normal de São Paulo. De acordo com o texto desse compêndio, era imperativo que o professor conhecesse as leis do desenvolvimento infantil. Advertia-se que "Em todos os fenômenos naturais, a intervenção do homem só é eficiente, quando respeita as leis que regem tais fenômenos" (DÓRIA, 1933, p. 20). Trata-se de uma variação de um enunciado recorrente nos livros de psicologia da época, possivelmente referido a partir de Claparède, que o adaptou ao campo educacional a partir da obra de Bacon:

O filósofo Bacon pronunciou outrora uma frase muito profunda, que deveria ser inscrita em letras de ouro no frontão dos nossos estabelecimentos de instrução pública ou privada: 'Não se obriga a natureza, a não ser obedecendo-lhe'. Sim, é preciso obedecer à natureza da criança, se dela queremos fazer alguma coisa; é a condição sine qua non (CLAPARÈDE, 1951, p. 118).

Esse enunciado foi retomado por outros autores (AZEVEDO, 1936; MENDES, 1943) e participou no deslocamento da verdade do discurso de autoridade dos professores para o discurso verdadeiro, "conforme a natureza" da psicologia, que se tornou um dos aspectos centrais da renovação escolar pretendida pelo movimento da Escola Nova. Explicita que o apelo para que os professores submetessem o seu próprio discurso à psicologia não pretendeu 
levá-los a renunciar ao seu poder. Ao contrário, associou-se à promessa de um poder ainda maior, mais eficaz e legítimo (ROSE, 2011). Obedecer a natureza da criança era o segredo para poder transformá-la sem dispêndio excessivo de energia, evitando-se a resistência e o ressentimento que poderia ser provocado no aluno caso o professor decidisse impor a sua autoridade.

No último capítulo desse livro, Sampaio Dória defendia a autonomia didática do professor, argumentando que sem liberdade de decisão os professores não se responsabilizariam pelos resultados de seu ensino. $\mathrm{Na}$ avaliação do autor, a pedagogia era uma ciência atrasada, que contava com poucas verdades gerais bem estabelecidas em meio a muitas hipóteses. Uma vez que não era possível assegurar que uma determinada maneira de ensinar era a única correta, não fazia sentido pretender instituir a uniformização dos métodos. Apesar disso, a autonomia didática não dispensava o professor de obedecer às "leis" do desenvolvimento infantil, que contraindicava, por exemplo, o "escolasticismo oco" ou o aprendizado pela simples memorização, sem a compreensão do conteúdo decorado:

\footnotetext{
Dentro do respeito à mentalidade infantil, o professor pode ensinar à vontade, exerce a soberania do sim e do não. Contra as leis do espírito evolutivo dos educandos, não tem o professor nenhum poder justo. Não pode, por exemplo, admitir as tarefas de cor, porque violam as leis da linguagem, segundo as quais a palavra sem a sua significação é fenômeno mutilado. Contra a natureza humana, contra as leis da fisiologia e da psicologia, a autonomia didática seria, repitamos, crime ou inconsciência (DÓRIA, 1933, p. 424).
}

Em Educação, o problema que se apresentava como o mais desafiador para a escola não eram as dificuldades de aprendizagem do aluno, mas sim o mau ensino, cujas causas eram múltiplas, mas estavam sempre ligadas à ignorância das leis pedagógicas ou à falta de vocação do professor. Para Sampaio Dória, a melhoria do ensino e a superação das dificuldades vividas nas escolas dependiam do progresso do conhecimento das ciências pedagógica e psicológica.

Lourenço Filho, seu sucessor, realizou sua formação na Escola Normal de Pirassununga, com complementação na Escola Normal de São Paulo, e na Faculdade de Direito do Largo São Francisco. Entre 1922 e 1923 empreendeu a Reforma do Ensino do Ceará e instalou o laboratório de psicologia na Escola Normal de Fortaleza, para a realização de pesquisas que subsidiassem a formação dos professores. Em 1925 passou a ocupar o lugar de seu mestre Sampaio Dória na cátedra de Psicologia na Escola Normal Caetano de Campos e na condução do laboratório de psicologia experimental dessa instituição, onde passou a realizar diversos estudos, dedicando-se especialmente ao desenvolvimento dos testes ABC para a 
avaliação da maturidade dos alunos para o aprendizado da leitura e da escrita. Em 1930 tornouse Diretor Geral do Ensino do Estado de São Paulo e, buscando uma solução para o problema do elevado índice de reprovações na primeira série do ensino primário, empreendeu a reorganização das classes escolares a partir dos resultados da aplicação dos testes ABC, que serão analisados no terceiro capítulo. No mesmo ano, veio a lume o livro Introdução ao Estudo da Escola Nova, o qual se tornou uma das principais referências sobre os princípios do movimento escolanovista no Brasil, tendo sido reeditado 17 vezes até 2002 (CAMPOS et al., 2004, p. 165).

Introdução ao Estudo da Escola Nova (1930) é, entre os textos aqui examinados, aquele que mais se aproxima do Manifesto, tendo provavelmente servido como uma de suas referências fundamentais. Apresentava a psicologia como a ciência que havia tornado possível o movimento renovador da educação escolar. $\mathrm{O}$ autor mostrava-se admirado com os seus progressos e suas inestimáveis contribuições, ao mesmo tempo em que afirmava tratar-se de uma ciência que estava ainda em sua infância. Estabelecia a mesma demarcação entre os contributos da psicologia e da filosofia para a educação que se apresentaria em seguida no Manifesto e que se tornou recorrente nos discursos do período: a filosofia estabelecia os fins da educação, ao oferecer respostas à pergunta "Que deve ser o homem?", enquanto os conhecimentos científicos da biologia e da psicologia, em especial da psicologia genética, buscavam responder a outra indagação, decorrente da anterior: "Como obter esse tipo de homem?" (LOURENÇO FILHO, 1930, p. 19).

Quanto à primeira questão, afirmava que, na perspectiva da Escola Nova, a finalidade da educação era promover a adaptação de todos os indivíduos à sociedade e não, como outrora, favorecer a formação intelectual de uma aristocracia. Outra finalidade da escola era promover a solidariedade, a cooperação entre os indivíduos e os grupos sociais e a paz. Para atingir esse propósito, era preciso substituir o trabalho individual característico da escola tradicional pelo trabalho em grupo. Adiante no texto, o autor ponderava que, embora coubesse à filosofia estabelecer os fins da educação e proporcionar à pedagogia "uma concepção do universo e do destino humano", ao refletir sobre o "problema do espírito", já não se admitia uma filosofia que desprezasse as contribuições da ciência, de modo que a psicologia influía duplamente na pedagogia, "indiretamente, esclarecendo seus problemas teleológicos, através da filosofia; diretamente, fornecendo os princípios da ciência pura, para aplicação prática, para a técnica educativa, propriamente dita" (idem). Dessa maneira, a própria filosofia, no seio da qual surgira 
a psicologia, antes de se destacar como disciplina autônoma, devia adaptar-se à ciência psicológica:

\begin{abstract}
A ciência diz o que é, não o que deve ser. A filosofia pretende indicar ao homem justamente o que deve ser, não o que é. Aperfeiçoe-se embora a ciência, a filosofia não desaparecerá. Ela se modifica, porém, ao influxo das novas conquistas da ciência. Filosofia absolutamente a priori parece hoje cogitação demasiado cândida... (LOURENÇO FILHO, 1930, p. 34).
\end{abstract}

Feita essa ponderação, Lourenço Filho discorria sobre quatro "princípios gerais da filosofia atual do conhecimento, com base na psicologia científica”. Em primeiro lugar, a compreensão genética dos fenômenos, que levava a explicar o superior pelo inferior, ou seja, a criança pelo animal e o selvagem, e o adulto pela criança, conforme a teoria da recapitulação (LOURENÇO FILHO, 1930, p. 41); em seguida, a substituição de uma concepção antropocêntrica por uma concepção naturalista do conhecimento, segundo a qual o pensamento pode ser melhor explicado não por conceitos metafísicos, mas pelas exigências da vida social; em terceiro lugar, a substituição da perspectiva analítica pela perspectiva sintética, ou seja, a preferência, nos estudos psicológicos modernos, pela explicação do comportamento total em uma situação total, em vez da investigação dos efeitos de excitantes isolados e, por último, a associação entre a psicologia e a explicação sociológica na compreensão da atividade mental, uma vez que "a psicologia humana, desde que a criança adquire a linguagem, é toda ela uma inter-psicologia, e só se pode explicar pelas influências coletivas" (LOURENÇO FILHO, 1930, p. 43).

Desses princípios psicológicos derivavam-se as consequências pedagógicas assumidas pela Escola Nova. O autor afirmava que a ciência psicológica tinha duas contribuições a oferecer à educação escolar, as quais se referiam à sua organização estática e à sua organização dinâmica. Quanto à organização estática, tratava-se fundamentalmente do diagnóstico das aptidões individuais, tendo em vista a formação de turmas homogêneas quanto à inteligência e a separação dos anormais de inteligência e dos super-normais para programas de educação especial.

Quanto à organização dinâmica do ensino, tratava-se da arte de ensinar. A concepção genética do conhecimento determinava a necessidade de transformação nos programas, tal como anunciada no Manifesto. "Dantes se imaginaram programas que as crianças devessem aprender. Hoje se imaginam programas que as crianças possam aprender, de acordo com as suas condições de desenvolvimento" (LOURENÇO FILHO, 1930, p. 44). A concepção 
vitalista alterou por sua vez o alvo da aprendizagem. Já não se tratava de dirigir o ensino à consciência e à inteligência do aluno, mas de orientá-lo de acordo com o interesse da criança, concebido como expressão de uma necessidade bio-psicológica do desenvolvimento. "Só se aprende realmente aquilo que interessa". A compreensão sintética do conhecimento, por sua vez, também impunha a revisão dos programas organizados por disciplinas:

\begin{abstract}
Dantes se ensinava por matérias, por séries de conhecimentos, entre si relacionados pela lógica do adulto. E tudo isso, separadamente. A psicologia vem demonstrando que tal ensino atenta contra as leis gerais da atividade psicológica, contra a evolução genética, contra a ação coordenadora dos interesses naturais da criança. Ao envez de matérias, assim separadas, propõe a psicologia que se ensine por séries de problemas, que globalizem os conhecimentos que se querem ver produzidos (LOURENÇO FILHO, 1930, p. 46).
\end{abstract}

Finalmente, a crítica social dos fins da escola demandava o trabalho em comunidade em substituição ao trabalho individual, de maneira a formar o "sentimento de cooperação, a solidariedade social, a disciplina bem compreendida dos que comandam e dos que são comandados" e, em sua expressão mais elevada, a busca do "ideal da paz pela escola" (LOURENÇO FILHO, 1930 p. 47). Embora não seja o propósito deste texto deter-se na crítica das concepções pedagógicas veiculadas nos discursos examinados, cabe aqui chamar atenção para a flagrante incoerência entre propor a homogeneização das classes mediante o recurso aos testes de inteligência e, logo em seguida, afirmar que na Escola Nova o ensino não se dirige à inteligência, mas orienta-se para o interesse da criança. Essa incoerência parece ser uma manifestação típica do que Maria Helena Patto (1988) designou como o discurso fraturado da Escola Nova, no qual as explicações para o fracasso escolar ora denunciam a inadequação do ensino oferecido nas escolas, ora atribuem a causa do fracasso à incapacidade intelectual dos alunos. O discurso que se está examinando afirmava que é preciso recorrer à psicologia porque uma parte das crianças era incapaz ou apresentava pouca capacidade de aprender, que era preciso identificá-las por meio de testes que tornassem possível a sua separação; em seguida sustentava que era preciso transformar o ensino porque, tal como se realizava, era inadequado à psicologia da criança.

Uma característica marcante dos discursos examinados, já bastante explorada pelas produções da história da educação no Brasil que incidem sobre a primeira metade do século XX, é a oposição que aqueles estabelecem entre a escola tradicional e a Escola Nova. Insistiase na substituição do ensino tradicional, caracterizado pela autoridade inconteste do professor, pela obrigação de cumprir um programa enciclopédico e decorar a matéria, por um ensino 
centrado no aluno, em seus interesses e sua atividade espontânea, no trabalho colaborativo em grupos. Contudo, um aspecto dessa oposição que parece não ter sido suficientemente realçado diz respeito à subordinação do discurso verdadeiro do professor ao discurso verdadeiro da ciência psicológica e suas implicações para o sentido da educação. No início deste texto afirmou-se que a vontade de verdade deslocou-se do discurso professoral (a cultura) à verdade da psicologia do aluno (a natureza). Observou-se adiante que nem por isso o professor foi destituído do seu poder sobre o aluno. Ao contrário, a expectativa era a da ampliação do seu poder, uma vez que, como tantas vezes se enunciou, era "preciso conhecer a natureza para poder dominá-la”. O professor já não podia apoiar a sua autoridade na tradição, no seu domínio de uma área do saber, mas passaria a sustentá-la no seu conhecimento da verdade sobre o aluno. Esse deslocamento não significou apenas a transformação dos métodos do ensino ou no modo de compreender o exercício da autoridade docente. Era o propósito mesmo da educação que se via assim transformado. Já não se tratava de transmitir saber, mas de favorecer o desenvolvimento dos indivíduos para o mundo moderno, para o futuro, de tornar os indivíduos capazes de produzir novos conhecimentos a partir de seus próprios interesses, de sua atividade espontânea, em um trabalho colaborativo.

Esse deslocamento da verdade do discurso do professor para os discursos da psicologia também não significou que a transformação do aluno por meio da educação tivesse se tornado mais aberta e indeterminada. Ao contrário, a identificação das aptidões individuais era requerida para subsidiar o governo de cada um e de todos no presente, tendo-se em vista o futuro. Os indivíduos passavam a ser orientados para o destino mais conforme a sua suposta natureza, correspondente à posição em que poderiam oferecer sua melhor contribuição para o progresso da sociedade. Se é possível falar em aumento de liberdade para o aluno, é preciso circunscrever o sentido dessa liberdade, a qual consistiu na valorização da atividade espontânea em um espaço previamente preparado pelo professor e continuamente observado por ele. Era necessário proporcionar liberdade ao aluno para que se tornasse possível surpreender a sua "verdadeira" natureza.

Pode-se ponderar que, se a produção de cultura é o que em tese permite libertar o homem do estado de natureza, a educação nova pretendeu invertê-la, ao defender a libertação da criança das imposições artificiais da cultura letrada, para que ela pudesse seguir/obedecer a sua própria natureza. Ao se identificarem as aptidões, a personalidade e o caráter da criança, promovia-se mais precisamente a sua adaptação ao meio social e a própria sociedade, por sua 
vez, se tornaria mais conforme à natureza humana, como queriam os pioneiros da Educação Nova.

Noemy da Silveira Rudolfer foi aluna e depois colega de Lourenço Filho na Escola Normal Padre Anchieta, em São Paulo. Em 1927 tornou-se sua assistente nas cadeiras de Psicologia Geral e Educacional na Escola Normal Caetano de Campos. Em 1929 foi aos Estados Unidos estudar no Teacher's College da Universidade de Colúmbia, onde tomou contato com as obras de Dewey, Kilpatrick, Thorndike, Gesell e outros autores ligados à psicologia educacional, cujas obras ajudou a divulgar no Brasil. De volta ao país, em 1931 assumiu o cargo de coordenação do Serviço de Psicologia Aplicada da Diretoria Geral do Ensino de São Paulo, também a convite de Lourenço Filho. No ano seguinte, substituiu o professor na Cátedra de Psicologia Educacional e no laboratório da Escola Normal Caetano de Campos. Em 1935 foi nomeada professora de Psicologia do Instituto Caetano de Campos, incorporado à Universidade de São Paulo, cargo que exerceu até o ano de 1954 (BAPTISTA, 2001, p. 337-340). Para o concurso de ingresso na instituição escreveu a monografia A evolução da psicologia educacional através de um histórico da psicologia moderna (1936) que posteriormente foi publicada como o livro Introdução à Psicologia Educacional (1938/1961).

Assim como Lourenço Filho, Noemy Rudolfer, examinava em seu livro as relações entre filosofia, psicologia e educação referindo-se às mesmas questões fundamentais: a primeira consistia em saber que transformações a educação deveria realizar nos indivíduos; a segunda dizia respeito aos "fatores mais propícios à produção dessas mudanças". A autora acrescentava ainda outros dois problemas, que remetiam a contribuição de outras disciplinas para a educação: "Ocupa-se, o terceiro, da maneira de ser dos indivíduos nos quais se vão operar as mudanças. E o quarto, diz respeito aos meios melhores e mais econômicos a empregar, a fim de assegurá-las” (RUDOLFER, 1938/1961, p. 2). Ampliava a análise acerca dos fins e dos meios da educação, detalhando a parte que cabia a cada disciplina no currículo de formação de professores. Entendia que à filosofia cabia determinar os fins gerais da educação e à sociologia os seus fins específicos, considerando-se as necessidades do meio social. Quanto ao segundo problema, o de saber que fatores eram mais propícios às mudanças desejadas, a pedagogia recorria à biologia educacional, à sociologia educacional e à psicologia educacional. A biologia e a psicologia também contribuíam para o esclarecimento das maneiras de ser dos indivíduos a serem transformados pela ação educativa, e a psicologia participaria ainda nas decisões relativas aos melhores métodos de ensino a empregar. 
No livro Introdução à Psicologia Educacional (1961), Rudolfer apresentava uma história evolutiva da psicologia e de suas contribuições à psicologia educacional, orientada para a busca da verdade e caracterizada pelo aperfeiçoamento dos procedimentos científicos. Descrevia a história da criação dos testes de inteligência e concluía afirmando que, graças à sua formulação, a psicologia educacional passou a "contar com dados objetivos para formulação de princípios de organização de agrupamentos homogêneos de alunos e para conhecimento dos mesmos" e ainda que "Em virtude desses princípios decorrentes da mensuração da inteligência, há maior possibilidade de adequação do ensino às diferenças individuais; logo, de maior rendimento escolar" (RUDOLFER, 1938/1961, p. 201). Considerava que os conhecimentos acerca dos problemas de aprendizagem, assim como a própria disciplina, vinham progredindo, mas deveriam avançar ainda mais no futuro.

Para Noemy Rudolfer, o problema que se apresentava, relativamente ao discurso verdadeiro da psicologia, era a multiplicidade de teorias. Sentindo-se desnorteada diante da dispersão dos pontos de vista da psicologia e da diversidade de escolas que a caracterizava, a autora decidira dedicar-se à investigação histórica da disciplina, a partir da qual concluíra que a adequada compreensão das psicologias modernas dependia do estudo de sua evolução histórica e que, nessa matéria, a melhor alternativa era a adoção de um "ponto de vista eclético". Seu livro Introdução à psicologia educacional, publicado pela primeira vez em 1938, é produto de seus investimentos nessa direção. Anos mais tarde, seu mestre Lourenço Filho expressaria ponto de vista semelhante no prefácio que escreveu para o livro Problemas da meninice, de Ofélia Boisson Cardoso, ao elogiar o ecletismo que caracterizava o trabalho da psicóloga: “(...) não se deixa a autora prender por nenhuma tendência exclusiva de estudo, ou 'sistema' psicológico, particular, assumindo, ao contrário, uma posição eclética de vigilante espírito crítico" (1964, p. 10).

Em meados da década de 1950, Noemy Rudolfer dedicou a conferência que pronunciou na sessão de posse da Diretoria da Sociedade de Psicologia de São Paulo a uma reflexão sobre os "Critérios em uso na moderna psicologia", examinando suas transformações na história da psicologia. Iniciava sua fala contrapondo-se à concepção recorrente nos manuais de psicologia, segundo a qual a investigação das questões psicológicas iniciara-se no campo da filosofia, antes que a psicologia se tornasse uma disciplina científica e autônoma. Ponderava que, por mais empíricos que fossem os resultados dos estudos psicológicos, esses derivavam de pesquisas e classificações realizadas a partir de categorias estabelecidas à priori e que a 
psicologia, "Nesse sentido, nunca se libertará da Filosofia" assim como todas as outras ciências. Ao encerrar sua conferência, retomava esse aspecto, referindo-se ainda à multiplicidade de critérios que era característica da disciplina e aos seus limites:

\begin{abstract}
À guisa de conclusão, pois: não nos afastemos da Filosofia se quisermos aproximarnos do bom critério. E, em Psicologia, não permitamos que anteparos resultantes de exclusividade de critérios - empírico, racionalista, gestaltista, psicanalista, topologista, behaviorista, matemático, estatístico, clínico, individualista, antropologista, ecológico, ou qualquer outro que falte nesta enumeração - nos fechem os olhos para a multiplicidade dos fenômenos psíquicos, para a interdependência dos objetos, para o imperativo das interrelações - 'pesquisador e seu mundo psíquicocampo-objeto-método', para as necessárias limitações de nossa tarefa. Ignoramos muito. Quase tudo está por descobrir. 'This nasty little science', na expressão de James. Sejamos humildes, inquietos, modestos e insatisfeitos. Não nos deixemos escravizar por métodos, critérios, sistemas, objetos. Só uma atitude sem compromissos apriorísticos pode levar avante a ciência psicológica (RUDOLFER, 1956, p. 53).
\end{abstract}

Esse texto de Noemy Rudolfer é, entre os que aqui se examinou, o que melhor evidencia a coexistência nos discursos da época entre a vontade de verdade, a confiança no conhecimento científico da psicologia e a percepção de que essa era uma ciência em desenvolvimento, caracterizada por poucas certezas, concepções distintas e muitas dúvidas. Avaliação semelhante aparece estampada no Manual de Psicologia Educacional (1955) redigido por Guerino Casassanta (1955, p. 15) "para as cadeiras de curso pedagógico dos Institutos de Educação do Brasil":

\footnotetext{
As investigações e pesquisas tendentes a desvendar a vida da alma são de remotos tempos e, neste momento, ainda se debatem os sábios em dúvidas e hipóteses. A bibliografia psicológica aumenta dia a dia, novos métodos e novas teorias surgem, procurando captar a vida da alma e explicá-la.
}

Enquanto na Escola Normal de São Paulo o ensino de psicologia era conduzido por professores formados em Direito e por normalistas unidos por relações mestre-discípulo e pela participação conjunta no Manifesto dos Pioneiros, no Rio de Janeiro era realizado por médicos que não se envolveram na elaboração do documento. Manoel Bomfim ingressou na Escola Normal do Rio de Janeiro em 1898 como professor de Educação Moral e Cívica, assumindo posteriormente o ensino da disciplina Pedagogia e Psicologia. Em 1902 realizou um estágio em Paris, sob a supervisão de Georges Dumas e Alfred Binet, tendo este último contribuído para a instalação do Laboratório de Psicologia Experimental do Pedagogium, em 1906. Bomfim foi diretor do laboratório e do próprio Pedagogium por quinze anos e teve atuação destacada no campo da educação. Criou os periódicos Educação e Ensino e Revista 
Pedagógica e exerceu os cargos de Diretor da Instrução Pública e da própria Escola Normal. A partir dos cursos realizados na instituição, escreveu os livros Lições de pedagogia (1920) e Noções de psicologia (1917), entre diversas outras obras no domínio da psicologia e da educação, mas também em outras áreas: História, Medicina, Sociologia e Biologia (ANTUNES, 2001, p. 92).

Manoel Bomfim considerava que o propósito da educação era promover a adaptação do indivíduo ao meio. Para ter êxito nesse mister, o professor precisava conhecer a psicologia da criança e compreender o meio físico, moral e social no qual ela iria viver. A pedagogia devia recorrer às ciências, que eram "físicas, naturais, históricas e sociais". Dentre todas, a que lhe oferecia mais subsídios era a psicologia, por meio da qual se podia conhecer tanto a natureza do aluno quanto compreender o meio moral e social, "que é constituído pelo conjunto de relações entre as consciências individuais, e resulta diretamente da vida psíquica". "Então, sem hesitação, podemos chegar à conclusão de que o estudo sistemático da pedagogia deve ser precedido do estudo também sistemático e científico da vida psíquica ou das atividades conscientes" (BOMFIM, 1920, p. 9-14.)

Bomfim foi discípulo de Binet e, como ele, recomendava a aplicação dos testes psicológicos para a identificação da debilidade mental, mas não chegava a defender o seu uso generalizado para a criação de classes selecionadas nas escolas. No apêndice do livro Noções de psicologia (1917), intitulado "Caracterização dos anormais escolares", o autor expressava uma compreensão da debilidade mental e das providências a tomar em face do problema bem de acordo com o discurso corrente no período. Assim como Binet, compreendia a deficiência mental em termos de um retardamento na "evolução das atividades intelectuais". Tal retardamento não se manifestava de maneira uniforme, mas, mais frequentemente, afetava sobretudo as atividades intelectuais superiores, o que significava que os retardados apresentavam percepção normal, mas mostravam-se incapazes de aproveitar essas percepções de maneira inteligente, de modo que o retardamento produzia um desequilíbrio que levava, na maior parte dos casos, à instabilidade. Entendia que a deficiência mental estava associada à imoralidade, de modo que punha em risco a organização escolar e social:

O anormal escolar, abandonado à vida comum, torna-se geralmente um tipo insocial. Os processos ordinários de instrução não chegam a dar-lhe o preparo e $\mathrm{o}$ desenvolvimento preciso para que ele possa tirar da inteligência os recursos que a vida exige de cada um. Sendo criaturas mais incapazes para se conformar com as regras da moral do que as crianças normais, dada a insuficiência do preparo mental, facilmente descambam para a desmoralização, o parasitismo e o crime (BOMFIM, 1917, p. 356). 
Embora as causas fossem "geralmente hereditárias", o autor considerava que um regime educativo especial, adequado a cada caso específico, podia favorecer a adaptação social, no caso dos considerados anormais escolares, cuja deficiência não era tão pronunciada quanto a dos idiotas, que eram ineducáveis e demandavam assistência e vigilância contínuas em asilos ou no interior da família. A própria definição de anormal escolar apresentada pelo autor estabelecia sua educabilidade, sendo a educação compreendida como adaptação ao meio social:

\begin{abstract}
Consideram-se como anormais escolares as crianças que apresentam anomalias psíquicas, de desenvolvimento, ou de coordenação e equilíbrio das respectivas atividades, e que, todavia, convenientemente educadas, podem corrigir-se e melhorar tanto que poderão viver, depois, a vida comum e livre, como personalidades úteis e moralizadas (BOMFIM, 1917, p. 355).
\end{abstract}

Ao tratar do desenvolvimento psicológico da criança, Bomfim valia-se da teoria da recapitulação, mas apresentava uma perspectiva original a propósito do tema. Atribuía grande importância à adaptação pessoal do indivíduo ao seu ambiente, num processo muito mais aberto e indeterminado do que o descrito nas interpretações usuais daquela teoria. Sua concepção implicava na valorização da experiência e dos conhecimentos dos adultos na educação da criança, distanciando-se quanto a esse aspecto da perspectiva dos educadores escolanovistas que se difundiria nas décadas seguintes:

\begin{abstract}
O homem deve completar a sua formação com uma adaptação nimiamente pessoal, consciente e inteligente. Daí a superioridade que lhe é dada na natureza: os seus recursos adaptativos, sendo pessoais, são por isso mesmo reformáveis e relativamente inesgotáveis. Mas, em compensação, para cada ser humano, essa adaptação consciente é uma verdadeira aquisição individual, em que ele condensa a experiência geral da espécie, e que equivale a uma gestação psíquica (período de educação). Daí resulta que nos primeiros tempos de vida livre a criança é relativamente um inválido - tem que ser amparada, assistida, guiada... Mais tarde, porém, a insuficiência do recém-nascido é fartamente resgatada no adulto, pela eficiência da ação que ele chega a desenvolver, graças a essa forma de adaptação consciente, reformável, ao mesmo tempo individual e socializada (BOMFIM, 1917, p, 321-322).
\end{abstract}

Plínio Olinto também era médico e, em 1916, ingressou por concurso na Escola Normal do Rio de Janeiro, onde tornou-se professor de Psicologia ao lado de Manoel Bomfim até 1930. Realizou no laboratório do Pedagogium uma pesquisa que deu origem ao artigo "A fadiga intelectual dos escolares", o qual foi mencionado por Claparède em seu livro Psicologia da Infância. Assim como Noemy Rudolfer, de São Paulo, Olinto interessou-se pelo estudo da história da psicologia, motivação que o levou a escrever um pequeno trabalho intitulado "A Psicologia experimental no Brasil”" (PENNA, 2001, p. 258). Como resultado de sua experiência 
docente, escreveu o compêndio Psicologia, publicado em 1934. Apresentava a disciplina como um campo de conhecimentos cujo objeto e estatuto não estavam ainda bem delimitados e constituíam motivos de discussões:

\begin{abstract}
Atualmente, quando dia a dia se estreitam as relações entre a vida orgânica e a vida mental, é mais fácil dizer o que não é psicologia do que propriamente defini-la. Não é ciência da alma, nem da consciência, nem da matéria. Segundo alguns, nem mesmo ciência ainda não é (OLINTO, 1934, p. 11).
\end{abstract}

Apesar disso, tal como se afirmava no Manifesto dos Pioneiros e em vários manuais, o estudo da psicologia era apresentado como condição indispensável para a renovação do ensino, que deveria se orientar pelo estudo científico da natureza infantil. Em Psicologia, esse enunciado aparecia na forma das seguintes interrogações: “Quem poderá ensinar crianças sem lhes conhecer a mentalidade?" e "Quantos erros cometeu a pedagogia por falta de psicologia?" A despeito da controvérsia em torno da sua definição, o autor apresentava sua própria concepção de psicologia, ligada, como em Bomfim, ao tema da adaptação ao meio:

A psicologia estuda as condutas que se definem no comportamento, interpreta as adaptações do indivíduo ao meio, as modificações do meio face ao indivíduo, num ajustamento que é a socialização.

Os estudos psicológicos tanto dependem da biologia como da sociologia e permanecem como uma ponte de passagem ligando as duas (OLINTO, 1934, p. 11).

Plínio Olinto apresentava os testes de inteligência como um recurso poderoso para a escola, que permitia homogeneizar as classes e identificar as crianças retardadas (1934, p.234). Por outro lado, ponderava que não era apenas a inteligência inata que os testes tratavam de medir, ao afirmar que "todas as provas e experiências destinadas a aquilatar a inteligência julgam igualmente do aprendizado". (OLINTO, 1934, p. 232), invalidando assim o emprego dos testes para a legitimação do determinismo biológico. Além disso, havia diversos graus de retardamento, de modo que a classificação era difícil de realizar, sendo imprecisos os limites entre as diversas categorias. O autor observava que, mesmo na divisão entre "anormais de asilo" e "anormais de escola" havia, às vezes, troca de elementos (OLINTO, 1934, p. 259). Ele também tornava problemática a relação entre os resultados obtidos nos testes de Q.I. e a determinação da normalidade, ao se perguntar: "Os quocientes de inteligência são de grande valor na prática psico-pedagógica. Contudo, o problema da normalidade, do chamado equilíbrio mental, continua. Pois se a normalidade fisiológica é impossível de obter, o que não será da normalidade psicológica?” (OLINTO, 1934, p. 235). Adiante, o autor questionava uma concepção corrente acerca da normalidade, ao ponderar que o "conceito popular de que em 
certos indivíduos tal ou qual bossa mais se desenvolve em prejuízo de outras, parece fundado na convicção de que, para a normalidade seria necessário uma equivalência de todas as funções da mentalidade" (OLINTO, 1934, p. 235). Ele considerava que os testes psicológicos eram importantes para a orientação profissional, como recursos auxiliares no estudo fisiológico e psicológico dos estudantes para a identificação das suas aptidões naturais, tendo em vista o seu encaminhamento para os trabalhos mais adequados às suas capacidades individuais. Mesmo assim, recomendava sua associação com outros critérios e procedimentos de avaliação, tais como o desempenho escolar, provas de laboratório e anamneses, possivelmente porque não considerava os testes suficientes para uma identificação segura das vocações profissionais.

Na Escola Normal do Rio de Janeiro, os médicos-professores Plínio Olinto e Manoel Bomfim afirmavam, como em São Paulo, o valor e a necessidade do estudo da psicologia pelo professorado para que as práticas escolares adquirissem respaldo científico. Mas, enquanto os professores paulistas costumavam iniciar o estudo da disciplina a partir da distinção entre as contribuições da filosofia e da psicologia para a educação, os discursos examinados de Olinto e Bomfim pareciam favorecer uma compreensão da psicologia mais aproximada da biologia, ao enfatizarem o estudo dos processos de adaptação do indivíduo ao meio.

No mesmo período, em Minas Gerais, Helena Antipoff, psicóloga russa recémchegada ao Brasil, fazia uma série de investigações sobre as crianças brasileiras recorrendo ao método dos testes e tecia suas próprias ressalvas ao emprego desses instrumentos de mensuração das inteligências. Helena Antipoff chegou ao país em 1929 para atuar como professora de psicologia na Escola de Aperfeiçoamento para professores de Belo Horizonte. Tratava-se da primeira instituição de ensino superior para a formação de professores no Brasil, instituída como parte das realizações da reforma do ensino empreendida por Francisco Campos em Minas Gerais, que tinha como um de seus objetivos principais a renovação da formação docente e do ensino por meio do estudo da psicologia.

Ao chegar ao porto de Santos, a psicóloga foi recebida por seu colega Léon Walther, que se preparava para voltar à Europa. Com ele estavam Lourenço Filho e Noemy Rudolfer, que a levaram para conhecer a Escola Normal Caetano de Campos e outras escolas e institutos onde se desenvolvia a psicologia educacional em São Paulo. De lá, a psicóloga seguiu para a Escola de Aperfeiçoamento de Professores, onde encarregou-se do ensino de psicologia, da direção do laboratório destinado às investigações na área e da assessoria às escolas para aplicação de testes de inteligência, tendo em vista a organização das classes homogêneas e das 
classes especiais para os alunos avaliados como deficientes. A partir da experiência que tivera no Instituto Jean Jacques Rousseau, na Suíça, Antipoff procurou associar teoria e prática no ensino da matéria, incluindo a realização de demonstrações no Laboratório, atividades de autoobservação feitas pelas futuras professorandas e a elaboração de trabalhos práticos nos grupos escolares da cidade (CAMPOS; LOURENÇO; ANTONINI, 2002).

Assim como Claparède, Helena Antipoff manifestou em seus trabalhos tanto interesse quanto críticas e questionamentos aos testes de inteligência desenvolvidos por Binet e Simon e os outros que se seguiram. Em texto autobiográfico publicado no livro A escola sob medida, Claparède assim se pronunciava:

\begin{abstract}
Ora, o método dos testes põe, ele mesmo, numerosos problemas, e preocupei-me justamente com alguns destes, principalmente com o problema da constância dos sujeitos. A aptidão de um sujeito varia de dia para dia. Qual será o 'verdadeiro valor' da aptidão de um indivíduo? Dediquei, juntamente com minhas assistentes Mme. Fejgin e Antipoff, algumas pesquisas sobre tão importante questão (CLAPARÈDE, 1951, p. 52).
\end{abstract}

Em artigo redigido no ano de 1931, Helena Antipoff relatava uma pesquisa que realizara com as crianças de Belo Horizonte, com o objetivo de avaliar o seu desenvolvimento mental, a partir da aplicação de três testes para a medida da inteligência geral, os de Goodenough; Dearborn e Ballard. Nesse trabalho, discutia o conceito de inteligência e expressava a sua convicção de que aquilo que os testes mediam não correspondia a um atributo puramente natural, mas à "inteligência civilizada”. Em suas pesquisas anteriores realizadas na Rússia no período pós-revolucionário, quando trabalhou no diagnóstico de crianças que haviam sido distanciadas de suas famílias e estavam abrigadas, observou que a maior parte delas evidenciava grande inteligência para enfrentar as condições adversas em que viviam e buscar meios de satisfazer suas necessidades imediatas. Apesar disso, quando submetidas aos testes de inteligência, seus resultados eram inferiores aos apresentados pelas crianças que viviam com suas famílias e frequentavam a escola. Essa experiência levara a autora a observar que

À margem da família, da escola e da sociedade com suas leis e suas regras, essas crianças se formavam, em uma palavra, à margem da vida civilizada. Não sendo destituídas de inteligência natural, não possuíam precisamente essa inteligência que se tributa e se disciplina ao contato do exemplo no seio do regime regrado e das exigências impostas pela vida convencional da família ou da escola, essa inteligência civilizada, que perscrutamos por meio dos nossos testes chamados de inteligência geral (ANTIPOFF, 1931, p. 86). 
Suas considerações acerca dos efeitos das oportunidades sociais sobre os resultados desiguais obtidos nos testes de inteligência por indivíduos pertencentes a grupos distintos também punham em questão a diferença de desempenho intelectual entre brancos e negros, afirmada por pesquisadores norte-americanos:

\begin{abstract}
Quando os americanos do norte se dispunham em publicar as normas comparativas de inteligência do homem de cor e do branco, essas normas, do ponto de vista psicológico puro, do ponto de vista das disposições mentais das raças, ainda não esclarecem satisfatoriamente. As vicissitudes econômicas e sociais do branco e do negro são como o dia e a noite. O branco teve, e tem ainda nos Estados Unidos, vantagens de ordem social que o negro não tem. Dai a uns e a outros, e isso durante séculos inteiros, as mesmas condições, e só então o resultado dos exames de inteligência poderá ter um interesse científico sobre o intelecto de uns e de outros (ANTIPOFF, 1931, p. 102).
\end{abstract}

A autora também expressava dúvidas quanto à própria objetividade dos testes, dadas as condições em que eram aplicados. Fazia essa advertência acerca da pesquisa que ela mesma havia conduzido, ao dizer que embora as experimentadoras tivessem sido bem orientadas e tivessem recebido instruções impressas sobre como proceder, essas providências não bastavam para eliminar as diferenças individuais entre elas, as quais interferiam nos resultados obtidos pelos sujeitos examinados, produzindo distorções:

\begin{abstract}
Grande parte delas, sem dúvida, corre por conta das diferenças individuais do temperamento, de caráter, que apresenta cada uma das trinta experimentadoras que aplicaram o teste. Uma sabe melhor disciplinar a classe; outra só o faz mediocremente; uma é consideravelmente clara na sua exposição, tem boa dicção, voz penetrante, sugestiva; outra tem voz dura, sem flexão; uma tem um desembaraço que desperta imediatamente nas crianças o desejo de se saírem o melhor possível; ao passo que outra, mais fria, menos viva, conseguirá das crianças apenas um trabalho sem interesse e sem entusiasmo. Aplicando a mesma técnica, umas apresentavam sempre melhores resultados do que outras, que não tinham precisamente este poder estimulante, embora obedecessem à técnica tão rigorosamente como as primeiras (ANTIPOFF, 1931, p. 98).
\end{abstract}

A psicóloga discutia os testes de inteligência de maneira mais complexa do que muitos de seus contemporâneos, levando em conta diversos elementos que podiam intervir em seus resultados. Apesar de todas as ressalvas que fazia aos testes psicológicos, ela era favorável ao seu emprego para a formação das classes selecionadas nos grupos escolares, considerando-as uma solução racional para o problema da organização do ensino. A propósito das turmas homogêneas, retomava um enunciado frequente nos discursos do período, segundo o qual era preciso pôr o homem certo no lugar certo e ainda observava que a classificação das crianças deveria ser periodicamente revista: 
Se a esse grupamento de crianças acrescentarmos ainda a preocupação da escolha de professores adequados a cada tipo de classe, poderemos esperar que o fato de haver colocado o 'right man on the right place' assegurará ainda mais o êxito de tal organização (ANTIPOFF,1935, p. 213).

Pois a classificação psicológica é coisa completamente diferente de uma classificação de botânica, por exemplo. Em botânica, tendo sido reconhecido o espécime, o naturalista o coloca em um dos escaninhos do herbário, e a planta aí permanecerá imóvel, esperando que um outro Linneu venha rever as bases de uma nova classificação, que vai removê-la de seu lugar. Em nossas classificações, o critério permanecendo o mesmo, o espécime, que é o indivíduo, pode mudar e evolver a tal ponto que o escaninho onde há tempos foi colocado, no fim de certo prazo, lhe será demasiadamente estreito ou largo (ANTIPOFF, 1935, p. 214).

Em sua tentativa de compreender as causas do atraso escolar de grande parte das crianças mineiras, a autora não apresentava uma resposta simples ou definitiva para a questão, mas entendia que uma compreensão adequada do problema exigia um estudo minucioso do caso de cada criança, que levasse em consideração seu ambiente social, a sua frequência à escola, a assiduidade e a competência profissional de seu professor e "enfim, a capacidade da criança ela própria” (ANTIPOFF, 1931, p. 99).

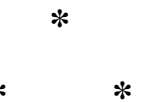

Até aqui, procurou-se descrever como se estabeleceu e difundiu a vontade de psicologia que caracteriza o campo educacional atualmente, recorrendo-se à análise de discursos produzidos na interface entre a educação e a psicologia na primeira metade do século XX no Brasil. Argumentou-se que na primeira metade do século XX operou-se um deslocamento da verdade do discurso do professor para o discurso da ciência psicológica. No entanto, não se tratou de reduzir o poder do mestre em face do aluno. Se o professor passou a ser advertido a conhecer e obedecer a natureza da criança, era para poder transformá-la. A mudança na vontade de verdade não implicou em destituição do poder do professor, como às vezes se tem dito em críticas contemporâneas à psicologização do ensino, mas na expectativa do exercício de um poder menos violento, mais eficaz e legítimo, porque fundamentado nos interesses e necessidades daqueles sobre os quais se exerce (ROSE, 2011). Por um lado, os professores passaram a demandar orientação especializada dos psicólogos para saber como agir em certas situações, por outro lado tornaram-se reconhecidos como especialistas em crianças por parte das famílias, sendo frequentemente consultados pelos pais em busca de orientações sobre como proceder para superar problemas de comportamento dos próprios filhos. 
Como evidencia o texto do Manifesto dos Pioneiros, a psicologia representou para os educadores escolanovistas um recurso para o questionamento da estratificação social, ao proporcionar um fundamento científico para a instituição de um sistema educacional em que o avanço no sistema de ensino fosse baseado no mérito e não na condição social. Uma escola única na qual cada indivíduo pudesse avançar tanto quanto permitissem suas aptidões supostamente naturais, identificadas pelos testes psicológicos, que prometiam captar de modo objetivo o potencial das crianças e, por essa razão, tornaram-se objeto de entusiasmo. Mas, como evidenciam os discursos examinados, na mesma época em que foram exaltados, os testes também foram alvo de uma série de questionamentos e objeções quanto ao seu emprego e seus resultados. Vários autores discutiram a crença de que eles mediam a capacidade intelectual inata e que essa fosse estável ao longo da vida. Observaram que os testes também mediam necessariamente o aprendizado e, portanto, seus resultados eram influenciados pelas condições favoráveis ou desfavoráveis de vida do examinado. Recomendaram ainda que seu emprego fosse associado a outros instrumentos psicológicos, tais como a observação da criança em suas atividades diárias, a entrevista com a sua professora e a sua mãe, que permitiriam reunir outros elementos para a compreensão da sua atitude geral.

Passados quase cem anos desde as primeiras manifestações mais entusiásticas acerca das contribuições da psicologia para o conhecimento do aluno e a organização do trabalho nas escolas, talvez não estejamos muito mais próximos das soluções para as dificuldades vividas nas escolas do que se estava então. Apesar disso, a vontade de psicologia nas escolas não diminuiu, mas, ao contrário, ampliou-se. A divulgação dos conhecimentos especializados sobre as crianças, seu desenvolvimento e suas necessidades não parece ter cumprido a promessa de aumentar o poder dos professores sobre a "natureza" dos alunos. Em vez disso, intensificou suas expectativas, ansiedades e dúvidas em relação às crianças que não se comportam ou não aprendem conforme o esperado. Esse efeito inesperado da produção e difusão do conhecimento científico sobre as crianças foi observado anteriormente por outros autores (COSTA, 2004; ELIAS, 2010). Deve-se em parte, às transformações nos modos como se criam e reformulam os problemas e as prescrições para superá-los, o que significa que não há um conjunto estável de problemas aos quais a psicologia se dedica, aproximando-se cada vez mais de soluções satisfatórias para cada um deles. Os próprios problemas se renovam, assim como os modos de investigá-los e as recomendações para ultrapassá-los. Relaciona-se ainda às mudanças vividas nas próprias escolas e nas sociedades em que se inserem, as quais produzem novas demandas 
para os estudos acadêmicos que, por sua vez, engendram novas recomendações para o enfrentamento dos problemas identificados. 


\title{
2. AUTORES E MODOS DE ENTRADA NO DISCURSO: A PSICOLOGIA ENSINADA AOS PROFESSORES.
}

\begin{abstract}
Seria absurdo negar, é claro, a existência do indivíduo que escreve e inventa. Mas penso que - ao menos desde uma certa época - o indivíduo que se põe a escrever um texto no horizonte do qual paira uma obra possível retoma por sua conta a função do autor: aquilo que ele escreve e o que não escreve, aquilo que desenha, mesmo a título de rascunho provisório, como esboço da obra, e o que deixa, vai cair como conversas cotidianas. Todo este jogo de diferenças é prescrito pela função do autor, tal como a recebe de sua época ou tal como ele, por sua vez, a modifica (FOUCAULT, 2010, p. 28-29).
\end{abstract}

A quem esteja familiarizado com os livros A ordem do discurso (2010) e A arqueologia do saber (2004), poderá parecer estranha a proposta de refletir sobre o ofício do intelectual a partir deles, pois nesses trabalhos Foucault propõe uma modalidade de análise do discurso que não privilegia a figura do autor. Em vez disso, detém-se no exame das relações que se pode caracterizar entre os próprios discursos como práticas, as quais permitem identificar um conjunto de regras a que os intelectuais encontram-se submetidos ao escreverem seus textos, ao pronunciarem as suas falas, ao delinearem a sua própria obra. A partir da perspectiva aberta pela análise arqueológica, o autor não é considerado como a origem do conhecimento e da verdade, mas como ocupante circunstancial de uma posição em um sistema de formação de enunciados. Foucault propõe-se a liberar os discursos daquilo a que se refere como "a sujeição antropológica" e que consiste em fazer do sujeito - sua consciência, seu pensamento, sua psicologia - a origem e o princípio de explicação dos enunciados. Em vez disso, toma como núcleo de análise os discursos das ciências humanas para verificar como se constituiu o homem como duplo empírico-transcendental, simultaneamente sujeito e objeto do conhecimento.

Considerar a atuação dos intelectuais recorrendo à arqueologia do saber requer uma mudança de foco nas análises: em vez de partir dos indivíduos, sua biografia, sua consciência, seu contexto social e histórico para compreender o sentido de sua obra, inicia-se a partir de um conjunto de discursos e procura-se caracterizar, a partir das regularidades manifestas no nível dos textos, as práticas discursivas em que se envolveram os seus signatários. Uma vez que todo intelectual encontra-se engajado nessas práticas, a possibilidade de examinar e descrever as regras subjacentes a diferentes formações discursivas permite analisar uma dimensão central 
das suas atividades. Segundo Alfredo Veiga-Neto, a propósito dessa modalidade de análise, "aquele que enuncia um discurso é que traz, em si, uma instituição e manifesta, por si, uma ordem que lhe é anterior e na qual ele está imerso" (VEIGA-NETO, 2011, p. 99). A propósito, vale lembrar a Resposta a uma questão ${ }^{5}$, reação de Foucault a uma questão que lhe foi dirigida antes mesmo da publicação de A arqueologia do saber. Conforme Thiago Ribas (2017, p.44),

Contra a objeção de aprisionar o Homem em um sistema de pensamento fechado que só 'um apelo ao acontecimento selvagem' seria capaz de transformar, Foucault começa sua resposta mostrando que para ele não se trata de uma oposição simples entre o sistema ou a liberdade humana, mas sim de um estudo do funcionamento de diferentes sistemas discursivos que, por fazer aparecer a multiplicidade dos enunciados, permitirá um diagnóstico sobre o nosso pensamento atual.

Atualmente, proliferam no campo educacional "pesquisas que se propõem a analisar discursos - de professores e professoras, de alunos de diferentes níveis, de instituições ligadas à educação, de textos oficiais sobre políticas educacionais, entre outros" (FISCHER, 2012, p. 73). A perspectiva foucaultiana de análise do discurso, além de oferecer ricas possibilidades para a reflexão sobre o que se diz, o ça parle no domínio da educação, como afirma Rosa Maria Bueno Fischer (FISCHER, 2001, p. 205), pode contribuir para pensar de outro modo as próprias práticas discursivas dos intelectuais na área.

Este capítulo recorre a escritos de Foucault sobre a análise do discurso com o objetivo de caracterizar a prática partilhada por um grupo específico de intelectuais, aqueles que se dedicaram à escrita de manuais de ensino destinados a professores em formação. Incide especificamente sobre os discursos da psicologia, disciplina que se tornou central nos currículos, apresentando-se como fundamentação científica do ensino, ao dar acesso às verdades sobre a criança e o seu desenvolvimento, seu aprendizado e suas necessidades. A análise toma como fontes primárias 51 manuais publicados no Brasil no decorrer do século XX e orienta-se por questões como as seguintes: Que condições precisaram ser atendidas por um intelectual para ocupar a posição de autor desse tipo de livro? Como se caracteriza a prática discursiva partilhada por esses autores? Que objetos, conceitos e escolhas teóricas constituíram a partir de sua escrita? Muitos autores participaram nessa formação discursiva, mas certamente não qualquer pessoa. No decorrer do século XX variaram as condições requeridas para a escrita de um manual de psicologia educacional, as quais incluíram a posse de um diploma, a ocupação de certos cargos institucionais e a experiência docente. A escrita dos manuais associou-se

\footnotetext{
${ }^{5}$ FOUCAULT, M. Dits et écrits I, p. 674 apud RIBAS, Thiago Fortes. Foucault: saber, verdade e política. São Paulo: Intermeios, 2017.
} 
frequentemente ao estudo dos autores estrangeiros para a preparação de aulas e, às vezes, à realização de pesquisas e eventos acadêmicos. A criança em desenvolvimento constituiu um objeto central do discurso, e a sua descrição esteve estreitamente associada a considerações sobre as influências relativas dos fatores associados a nature x nurture no desenvolvimento.

A seguir, apresentam-se considerações teórico-metodológicas sobre a posição de sujeito do enunciado e a função-autor a partir dos escritos de Foucault e suas implicações para a compreensão do trabalho do intelectual. Depois disso, a partir do exame dos manuais, buscase caracterizar mais detidamente as práticas discursivas partilhadas pelos autores envolvidos em sua produção, bem como as transformações que se pôde observar no período considerado.

\subsection{Considerações teórico-metodológicas sobre as modalidades enunciativas e a função autor}

Em A arqueologia do saber, Foucault se propõe a operar com a noção de descontinuidade na história do pensamento. Observa que embora essa noção já estivesse incorporada há décadas no trabalho dos historiadores, demorava a ser assimilada nesse domínio em particular, porque, segundo ele, “A história contínua é o correlato indispensável à função fundadora do sujeito" (2004, p. 14) e serve de abrigo para a soberania da consciência. O propósito de evidenciar a descontinuidade na história do pensamento, que já se delineava em A história da loucura (2000), constitui uma tentativa de pensar um método que permita liberar a história do tema antropológico, do pressuposto de que o homem encontra-se na origem do conhecimento. As ciências humanas, ou, mais precisamente, os saberes sobre o homem são o seu objeto. $\mathrm{O}$ autor procura formular uma descrição histórica dessas disciplinas que não seja evolutiva ou progressista e que além disso, renuncie a toda forma de antropologismo, ou seja, a fundamentar os discursos e suas transformações seja no homem como objeto estável, desde sempre aí, seja na consciência transcendental do sujeito. Quer, ao contrário, verificar justamente como pôde se formar discursivamente esse duplo empírico-transcendental.

O autor começa por questionar as noções de tradição, influência, desenvolvimento e evolução, mentalidade e espírito, por constatar a dificuldade de demonstrar as relações de continuidade entre os discursos a partir dessas noções, geralmente aceitas antes de qualquer exame. E desconfia dos agrupamentos familiares realizados a partir das categorias ciência, literatura, filosofia, religião, que são relativamente recentes e cujas fronteiras não são muito 
bem definidas. Indaga se unidades discursivas como " $a$ medicina, $a$ gramática, $a$ economia política" não são apenas reagrupamentos retrospectivos, que nos enganam sobre o passado das ciências, fazendo-as coincidir com o progresso da razão e do entendimento acerca dos mesmos objetos ou das mesmas questões desde sempre colocadas, concepção que ele pretende desafiar.

Depois de esclarecer que a modalidade de história dos sistemas de pensamento que se propõe a fazer renuncia à continuidade, à perspectiva evolutiva e teleológica e, além disso, pretende afastar-se do antropologismo, ou seja do pressuposto do homem como duplo empírico-transcendental, o autor se propõe a analisar o próprio discurso e suas regularidades. Após pôr em questão as principais unidades discursivas às quais estamos habituados - o livro, a obra - propõe-se a tomar como ponto de partida as "disciplinas". Entende que essas unidades também são duvidosas e decide verificar se elas se sustentam como "formações discursivas". Em busca de critérios para a delimitação das formações discursivas, formula então quatro hipóteses, as de que a unidade do discurso se apoia no objeto, ou na modalidade enunciativa, ou na estrutura conceitual ou nos temas e teorias identificáveis em um conjunto de textos. Todas elas são examinadas e recusadas, pois em todos os casos, o que se verifica não é a unidade, mas a dispersão, seja dos objetos, seja dos modos de enunciar ou dos conceitos ou dos temas e teorias. Cada um desses aspectos é detalhado nos capítulos seguintes de A arqueologia do saber (2004).

No que diz respeito aos objetos, o autor observa que no interior de uma mesma disciplina, por exemplo a psicopatologia, os objetos são diversos e instáveis. Alguns deixaram de existir, alguns novos surgiram, outros se transformaram. Mas pode-se identificar as regras que permitiram a formação desses objetos dispersos, que se constituíram a partir das interações entre superfícies de emergência, instâncias de delimitação e grades de especificação. A loucura surge nas famílias, no trabalho, na comunidade religiosa e posteriormente na arte, no regime penal, que são suas superfícies de emergência. Suas instâncias de delimitação são a medicina, a justiça, a autoridade religiosa e enfim a crítica literária e artística. As grades de especificação aplicadas à loucura foram a distinção corpo/ alma, a vida e a história do indivíduo. Portanto, o discurso não descreve objetos exteriores, mas forma os objetos de que fala, visto que os objetos resultam das relações entre esses diferentes planos de diferenciação. Sendo assim, o objetivo da análise não é atravessar o discurso para alcançar as coisas além dele, mas analisar o discurso como instância de formação de objetos:

As condições para que apareça um objeto de discurso, as condições históricas para que dele se possa dizer 'alguma coisa' e para que dele várias pessoas possam dizer 
coisas diferentes, as condições para que ele se inscreva em um domínio de parentesco com outros objetos, para que possa estabelecer com eles relações de semelhança, de vizinhança, de afastamento, de diferença, de transformação - essas condições, como se vê, são numerosas e importantes. Isto significa que não se pode falar qualquer coisa em qualquer época; não é fácil dizer alguma coisa nova; não basta abrir os olhos, prestar atenção, ou tomar consciência, para que novos objetos logo se iluminem e, na superfície do solo lancem sua primeira claridade. Mas esta dificuldade não é apenas negativa; não se deve associá-la a um obstáculo cujo poder seria, exclusivamente, de cegar, perturbar, impedir a descoberta, mascarar a pureza da evidência ou a obstinação muda das próprias coisas; o objeto não espera nos limbos a ordem que vai liberá-lo e permitir-lhe que se encarne em uma visível e loquaz objetividade; ele não preexiste a si mesmo, retido por algum obstáculo aos primeiros contornos da luz, mas existe sob as condições positivas de um feixe complexo de relações (FOUCAULT, 2004, p. 50).

A arqueologia dirige-se à formação discursiva dos objetos. Embora possa estar relacionado a algo que existe fora do discurso, o objeto não apresenta uma correspondência simples com o que está no mundo e, em todo caso, não é essa relação que se trata de examinar. Não se busca descrever o discurso como representação fiel ou infiel de algo exterior, mas de identificar a partir de que regras específicas se formam os objetos de um dado discurso.

A análise incide ainda sobre as modalidades enunciativas. Quanto a esse aspecto, busca identificar quem pode participar de um discurso em particular, em que lugares institucionais pode tomar a palavra e qual a posição do sujeito em relação aos objetos sobre os quais se pronuncia. A propósito do discurso médico, Foucault $(2004$, p. 58) observa que

\footnotetext{
As posições do sujeito se definem igualmente pela situação que lhe é possível ocupar em relação aos diversos domínios ou grupos de objetos: ele é sujeito que questiona, segundo uma certa grade de interrogações explícitas ou não, e que ouve, segundo um certo programa de informação; é sujeito que observa, segundo um quadro de traços característicos, e que anota, segundo um tipo descritivo; está situado a uma distância perceptiva ótica cujos limites demarcam a parcela de informação pertinente; utiliza intermediários instrumentais que modificam a escala da informação, deslocam o sujeito em relação ao nível perceptivo médio ou imediato, asseguram sua passagem de um nível superficial a um nível profundo, o fazem circular no espaço interior do corpo - dos sintomas manifestos aos órgãos, dos órgãos aos tecidos e dos tecidos, finalmente, às células. A essas situações perceptivas é preciso somar as posições que o sujeito pode ocupar na rede de informações (no ensino teórico ou na pedagogia hospitalar; no sistema da comunicação oral ou da documentação escrita: como emissor e receptor de observações, de relatórios, de dados estatísticos, de proposições teóricas gerais, de projetos ou de decisões).
}

As diferentes situações do médico, que dão oportunidade para os diferentes tipos de enunciados, são estabelecidas por um feixe de relações entre os espaços, as técnicas, os saberes disponíveis e as funções exercidas pelo médico. O discurso médico encontrou espaço propício para a sua elaboração e difusão no hospital, mas também no laboratório e no consultório particular. Recorreu à sua própria "biblioteca", formada não apenas pelos livros, mas também por um campo documentário constituído por relatórios, registros de observação, estatísticas 
etc. Os discursos da psicologia para professores em formação constituíram-se inicialmente nas faculdades de medicina e de direito, antes de se transferir para as escolas normais, seus laboratórios de psicologia experimental e as clínicas de higiene mental associadas às redes de ensino público e, posteriormente, para os cursos de graduação e pós-graduação das faculdades de educação e de psicologia. Para a psicologia educacional, o fato do discurso ser resultado de estudos realizados predominantemente na biblioteca ou no laboratório, em uma universidade estrangeira, em uma clínica de atendimento à crianças consideradas "problemas" ou em um grupo de pesquisas associado a um programa de pós-graduação é relevante na caracterização do seu sistema de formação e deve ser levado em conta.

É necessário, portanto, caracterizar a situação em que se encontra aquele que se pronuncia. As práticas em que está envolvido demanda um discurso do tipo diagnóstico, explicativo, pedagógico, combativo? Independentemente de ter mudado de ideia, o mesmo indivíduo pode formular discursos de tipos diferentes em razão da posição que ocupa ao tomar a palavra. Seu discurso não será o mesmo e não obedecerá às mesmas regras caso se pronuncie como professor em sala de aula, como pesquisador no laboratório ou em um congresso, como militante em uma manifestação. Em cada uma dessas situações há uma ordem do discurso, um conjunto de regras a serem observadas, mesmo que na maioria dos casos elas não se encontrem explicitamente formuladas e mesmo que o sujeito não esteja consciente de estar envolvido em uma prática regulada. Há modos previstos de iniciar a fala ou o texto, procedimentos para ligar os enunciados e para se referir a outros discursos, modos reconhecidos de associar um argumento ao nome de uma autoridade reconhecida no campo; de estabelecer a verdade das afirmações; de derivar consequências práticas ou recomendações para a ação das verdades estabelecidas; de formular exemplos. $\mathrm{Na}$ análise arqueológica, não se procura extrair o que pode haver de verdadeiro no discurso, desconsiderando-se todo o resto - as descrições de casos, as prescrições - nem se procura alcançar o pensamento ou a racionalidade do sujeito. Em vez disso, caracteriza-se o discurso tal como foi enunciado e identifica-se suas condições de possibilidade, os tipos de instituições, materiais e práticas que o tornaram possível. O próprio sujeito não é pensado como unidade de sentido ou como sujeito unificado, visto que o mesmo sujeito pode exercer práticas discursivas distintas, cada qual com as suas próprias regras.

O discurso, assim concebido, não é a manifestação, majestosamente desenvolvida, de um sujeito que pensa, que conhece e que o diz: é, ao contrário, um conjunto em que podem ser determinadas a dispersão do sujeito e sua descontinuidade em relação a si mesmo (FOUCAULT, 2004, p. 61). 
Além da formação dos objetos e das modalidades enunciativas, a arqueologia se volta ainda para a formação dos conceitos e dos temas e teorias, as quais são consideradas como estratégias ou modos de entrada possíveis em uma prática discursiva. Apesar da dispersão dos conceitos em um discurso, o exame dos enunciados pode permitir identificar regularidades no modo como os conceitos são articulados. Essa modalidade de análise não se interessa pela definição ideal dos conceitos, nem pretende fazer a história do conceito ou investigar seu desenvolvimento gradual na mente do autor, mas considera o discurso como espaço de emergência dos conceitos:

$\mathrm{Na}$ análise que aqui se propõe, as regras de formação têm seu lugar não na 'mentalidade' ou na consciência dos indivíduos, mas no próprio discurso; elas se impõem, por conseguinte, segundo um tipo de anonimato uniforme, a todos os indivíduos que tentam falar nesse campo discursivo (FOUCAULT, 2004, p. 69).

Cada formação discursiva permite identificar também certos temas ou teorias, a depender do seu nível de formalização, os quais correspondem a estratégias para a formação de enunciados. Para a arqueologia, a formação dessas estratégias não deve ser considerada como resultado de um processo evolutivo e nem do acaso das circunstâncias, mas da própria prática regulada do discurso, que abre um campo de opções possíveis. Quanto a essa dimensão, a análise pode direcionar-se à caracterização das alternativas que se encontram em um discurso e repartem enunciados formados a partir das mesmas regras em dois conjuntos, segundo a forma "ou bem isso... ou bem aquilo" (FOUCAULT, 2004, p. 73), assim como à caracterização da "economia da constelação discursiva" à qual o discurso pertence, ou seja, "o papel desempenhado pelo discurso estudado em relação aos que lhe são contemporâneos e vizinhos" (FOUCAULT, 2004, p. 74) e ainda às relações que se pode estabelecer entre o discurso e outras práticas. Assim como para os elementos precedentes - os objetos, as modalidades enunciativas e os conceitos - também no que diz respeito às estratégias, um discurso poderá ser individualizado sempre que se identificar o mesmo conjunto de regras de formação das estratégias. As escolhas estratégicas não são consideradas como a expressão de interesses individuais ou de grupos formados em outro lugar, mas como "maneiras reguladas (e descritíveis como tais) de utilizar possibilidades de discursos" (FOUCAULT, 2004, p. 77). Não se deve supor ainda que, sob as escolhas estratégicas divergentes na superfície do discurso haja o discurso ideal, que evolui lentamente até que as confusões na superfície se dissipem:

$\mathrm{E}$, assim como não seria preciso relacionar a formação dos objetos nem às palavras nem às coisas, a das enunciações, nem à forma pura do conhecimento nem ao sujeito psicológico, a dos conceitos, nem à estrutura da idealidade nem à sucessão das ideias, 
não é preciso relacionar a formação das escolhas teóricas nem a um projeto fundamental nem ao jogo secundário das opiniões (FOUCAULT, 2004, p. 78).

A arqueologia consiste numa análise histórica dos discursos tomados como "acontecimentos" e como "monumentos", ou seja, como modos de existência que apresentam uma espessura própria e não são meros reflexos ou representações de objetos exteriores. Além de caracterizar as relações entre seus elementos constituintes - objetos, modalidades enunciativas, conceitos, temas e teorias - considera ainda as relações entre os discursos e outros acontecimentos discursivos e não discursivos. Tais relações, no entanto, não são supostas $a$ priori, a análise recusa qualquer pressuposição de causalidade ou determinação entre os níveis discursivo e não discursivo, tem como princípio que "só a pesquisa concreta pode descobrir as formas específicas dessa articulação" (MACHADO, 1981, p. 179). Considerar os discursos como acontecimentos e monumentos implica ainda levar em conta um "efeito de raridade", ou seja, reconhecer que "os enunciados (por numerosos que sejam) estão sempre em déficit" em relação a tudo o que a língua permitiria formular (FOUCAULT, 2004, p. 135). Como observou Candiotto (2013, p. 40),

\begin{abstract}
Foucault precisa que a arqueologia quer ser a história 'não do ponto de vista dos indivíduos que falam' e sim da perspectiva das 'coisas ditas'. Ela opera na consistência do discurso, ao prescindir daquilo que se quis dizer, do fundo que permanece mudo detrás das frases; sua constituição é estabelecida pela 'diferença entre o que se poderia dizer corretamente numa época (segundo as regras da gramática e da lógica) e o que é efetivamente dito. O campo discursivo é a 'lei dessa diferença'.
\end{abstract}

Em sua aula inaugural proferida no Collège de France, ao discorrer sobre as modalidades de controle que incidem sobre o discurso, Foucault observava que no interior de cada cultura nem tudo pode ser dito, não se pode dizer qualquer coisa de qualquer modo e nem todo mundo está autorizado a falar de certas coisas. Dentre os modos de controle que incidem sobre o discurso, ele se referia à função do autor, que se manifesta como um princípio de agrupamento dos discursos e faz com que certos discursos, aqueles que têm autoria, sejam associados a uma identidade, uma biografia, uma formação, um pensamento, que então constituem o "foco da sua coerência" e indicam o modo como devem ser lidos. Anteriormente, no texto $O$ que é um autor? assinalara que

para um discurso, ter um nome de autor, o fato de que se pode dizer 'isto foi escrito por fulano' ou 'tal indivíduo é o autor', indica que esse discurso não é um discurso cotidiano, indiferente, um discurso flutuante e passageiro, imediatamente consumível, mas que se trata de um discurso que deve ser recebido de certa maneira 
e que deve, numa determinada cultura, receber um certo estatuto (FOUCAULT, 1992, p. 45).

Considerou que o princípio de autoria funciona também como um modo de classificação, e é preciso decidir, entre tudo o que foi pronunciado por um autor, o que faz parte de sua obra e o que deve ser deixado de fora. Para o intelectual que escreveu um compêndio para uma disciplina, que reúne as suas aulas, pode ser difícil distinguir a sua "obra" do seu ensino e de outras obras. Se, no livro publicado, ele reproduz em seus próprios termos um exemplo consagrado de um autor estrangeiro ou se, em uma aula, improvisa um exemplo que depois não publica, como decidir da autoria em cada caso? Quando se trata da produção intelectual dos professores, poder-se-ia levar em conta ainda: as entrevistas que eventualmente concedeu para o jornal da escola ou em outra situação, os discursos que preparou para eventos como formaturas ou datas comemorativas da escola, os planos de aulas, os textos traduzidos ou adaptados para uso dos alunos. Seria o caso de considerar ainda a elaboração de exercícios e questões de prova? As anotações sobre o mau comportamento dos alunos registradas no livro de ocorrências? Seu modo próprio de fazer anotações nos trabalhos dos alunos ou em seus boletins? Longe de ser exaustiva, essa relação é suficiente para evidenciar que não basta considerar como parte de sua obra tudo o que ficou registrado do que disse e escreveu, mas é preciso tomar uma série de decisões que podem se tornar difíceis de justificar.

\subsection{Os discursos da psicologia educacional destinados à formação de professores}

A opção por privilegiar nesta análise os manuais destinados à formação dos professores em vez das obras dos grandes psicólogos justifica-se em função do objetivo de compreender as relações que se pode estabelecer entre o discurso veiculado nesses livros e as condições específicas em que se encontravam os intelectuais brasileiros que atuaram nas escolas normais e posteriormente nos cursos de pedagogia e licenciatura, exercendo paralelamente ou alternadamente as funções professor, autor e pesquisador. Para tanto, é importante considerar a função e o tipo de reconhecimento conferido a esse tipo de texto, que não equivale ao que foi conferido aos discursos teóricos reconhecidos como grandes obras.

Quando se trata do discurso dos manuais de ensino, a questão da autoria apresenta especificidades que é preciso considerar, uma vez que frequentemente esses textos foram produzidos por professores, cuja atividade docente se sobrepunha à da escrita. Quase sempre foi nessa condição que se decidiram a sistematizar seus estudos das obras dos autores de 
referência, em sua grande maioria estrangeiros, ou se propuseram a reunir e publicar as suas aulas, de modo que frequentemente negaram a originalidade de seus trabalhos, praticamente renunciando à autoria. Como observou Vivian Batista da Silva, em extensa investigação sobre os manuais de Didática, "os manuais puderam ser chamados de obras de lectores, pois selecionaram ideias contidas nas obras de auctores" (2018, p. 60). Esse foi também o caso de muitos dos manuais de psicologia produzidos no Brasil, cujos autores eram responsáveis pelo ensino da matéria nas escolas normais ou cursos superiores de formação docente. A partir da leitura da introdução dos manuais, constata-se a recorrência com que se afirmava que o objetivo do livro não era trazer dados novos ou teorias inéditas, mas apenas apresentar em língua portuguesa uma introdução à matéria para os iniciantes, a partir da síntese do conteúdo da bibliografia, em grande parte disponível apenas em língua estrangeira. Com essa preocupação, alguns autores evitaram inclusive a exposição de seus próprios pontos de vista, entendendo que os alunos deveriam ser apresentados às diferentes perspectivas para formar seu próprio juízo sobre a matéria. Um exemplo interessante de como se pensou a distinção entre a posição de professor e a posição de autor foi encontrado no livro Compêndio de Psychologia (1925), de Henrique Geenen, para quem "Ao lente cabe dirigir a mente do aluno, não ao compêndio clássico que deve expor o mais claramente possível as várias opiniões sobre as questões debatidas, para que o aluno conheça o estado da questão" (Prefácio à $1^{\mathrm{a}}$. edição). É curioso observar como Geenen inverte as posições, tal como usualmente compreendidas, conferindo autoria ao professor, que expressava suas convicções para "dirigir a mente do aluno", mas não ao autor, que deveria se restringir a transmitir o conhecimento disponível. Compreensão análoga aparece décadas mais tarde, no livro Psicologia evolutiva: problemática do desenvolvimento (1983), em que Merval Rosa (1983, p. 9-10) atribui inventividade ao professor e ao aluno, mas não ao autor que, no caso do livro didático, deveria circunscrever-se à apresentação de um roteiro para o estudo da matéria:

Trata-se evidentemente de um trabalho didático a nível expositivo e destinado a principiantes no campo da psicologia. $\mathrm{O}$ autor não se propõe a apresentar teorias pessoais sobre os assuntos aqui tratados. Não há, portanto, no presente trabalho nenhuma pretensão de originalidade. $\mathrm{O}$ autor entende que o livro didático é produzido no contexto daquilo que Kuhn chama de 'ciência normal', em seu famoso ensaio sobre a estrutura das revoluções científicas. O livro didático é apenas um roteiro numa área de estudos. O valor econômico e a melhor utilização de um livro-texto dependem em grande parte da criatividade do professor e do próprio aluno que dele fizer uso.

Entre os procedimentos de controle que incidem sobre o discurso, Foucault se refere ao comentário. Em um nível se situam os discursos originários ou principais e em outro os 
discursos que os comentam, os quais tendem a ser menos importantes e duradouros. Essa distinção, contudo, não é estável, uma vez que um texto pode surgir como comentário para em seguida tornar-se principal em relação a outros textos que o comentam. Além disso, não se deve supor que os discursos originários não se referem a outros discursos, mas consistem na pura representação do mundo ou na transcrição do pensamento de seu autor. Para Foucault, também os discursos primordiais são recomposições inesperadas de outros discursos e assim sucessivamente. Quanto ao comentário, sua função é dupla, pois consiste tanto em fazer proliferar os discursos quanto em "dizer enfim o que estava articulado no texto primeiro" (FOUCAULT, 2010, p. 25). Se o comentário é um procedimento de controle dos discursos, é porque busca cerceá-lo, coibir a multiplicidade aberta pelo discurso principal. Foucault afirma, a propósito do comentário, que "o novo não está no que é dito, mas no acontecimento de sua volta" (FOUCAULT, 2010, p. 26), evidenciando que o comentário retém ou faz retornar o discurso principal, fixando-o e tentando impedi-lo de se transformar, em um esforço de impedir que outras coisas sejam ditas.

Quando se trata do livro didático, o comentário também apresenta especificidades, já que frequentemente corresponde à seleção dos pontos mais importantes dos textos principais e à sua tradução em linguagem acessível, para adequá-lo aos leitores principiantes. Dentre os livros de psicologia educacional, diversos foram aqueles cujos autores expressaram a preocupação em evitar estender a discussão teórica e preferiram, em vez disso, aproximar o conteúdo científico da vida prática, por meio de exemplos e ilustrações, para favorecer a compreensão dos professores em formação e serem úteis:

[...] pôs o autor mãos à obra com a determinação de produzir um livrinho que, não sendo absolutamente novidade, constituísse, entretanto, uma contribuição aos alunos das Escolas Normais e dos Institutos de Educação. Para isso, foram as lições ilustradas, tanto quanto possível, com exemplos e problemas da vida prática, eliminada a preocupação de debater teorias que complicam os estudos preliminares de tão importante matéria (CASASSANTA, 1955, s.p.).

Todos esses cuidados, se por um lado podem ter contribuído para despertar o interesse e facilitar o entendimento dos textos principais, por outro intensificaram o controle da apropriação das teorias psicológicas feita pelos normalistas, inclusive por meio de sua redução e simplificação. Muitos professores-autores foram principalmente comentadores das obras dos grandes psicólogos, cujas teorias procuraram traduzir e adaptar para uso dos estudantes brasileiros. Nessa condição, alguns entre eles escreveram manuais de outras disciplinas do curso normal, além da psicologia, como foi o caso de Afro do Amaral Fontoura, autor dos 
diversos livros que compuseram a Biblioteca Didática Brasileira, da Editora Aurora, e Theobaldo Miranda Santos, que escreveu os numerosos volumes da coleção Curso de Psicologia e Pedagogia, da Companhia Editora Nacional, e Ruy de Ayres Bello ${ }^{6}$. Tendo escrito tantos livros sobre matérias distintas, compreende-se que não poderiam mais do que sintetizar e expor didaticamente o conteúdo da bibliografia disponível em cada uma das áreas. Como observou Foucault (1992, p. 51), 'Não se constrói um 'autor filosófico' como um 'poeta'; e no século XVIII não se construía o autor de uma obra romanesca como hoje. No entanto, podemos encontrar através dos tempos uma certa invariável nas regras de construção do autor".

Os manuais de psicologia foram escritos no decorrer do século XX por professores que lecionavam inicialmente nas escolas normais, a partir da década de 1970, nos cursos de magistério e no período mais recente nos cursos de pedagogia e licenciaturas das universidades. Até a década de 1930, a formação dos autores era predominantemente em medicina, direito e filosofia; nas décadas de 1940 e 1960 realizara-se, na maioria dos casos, nas escolas normais e da década de 1970 em diante nas faculdades de Psicologia, Pedagogia, História ou Filosofia, às vezes em dois cursos superiores. Desde então os autores apresentam títulos de pós-graduação e exercem a docência em cursos superiores. Já no início do século XX diversos autores de manuais realizaram estudos no exterior para ampliar e aprofundar seus conhecimentos na área, tais como Manoel Bomfim que em 1902 foi a Paris estudar psicologia e tornou-se discípulo de Alfred Binet, com quem planejou a criação do primeiro laboratório de psicologia do país, no Pedagogium; Lourenço Filho, que esteve nos Estados Unidos, Argentina e Itália, e Noemy da Silveira Rudolfer, que também realizou estágio nos Estados Unidos. Uma análise das bibliografias indicadas nos manuais evidencia a presença expressiva de referências a obras de autores estrangeiros, muitas das quais citadas nos idiomas originais, principalmente inglês,

\footnotetext{
${ }^{6}$ Fontoura escreveu, entre outros, os seguintes livros: "Fundamentos da Educação (1 ${ }^{\mathrm{a}}$. ed.em 1949 e $8^{\mathrm{a}}$. ed. em

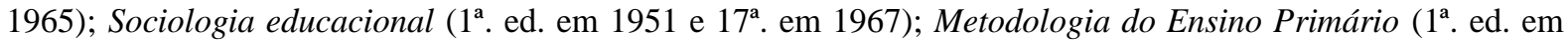
1955 e 16a . ed. em 1966); Psicologia Geral (1 ${ }^{\mathrm{a}}$. ed. em 1957 e $15^{\mathrm{a}}$ ed. em 1967)" (SILVA, 2018 p. 310). Theobaldo Miranda Santos, além de ter escrito Noções de psicologia educacional, foi autor de Metodologia do ensino primário (1955); Noções de prática de ensino (1958), Manual do professor primário (1962); Noções de pedagogia científica (1963) e ainda de "Noções de filosofia da educação; Noções de história da educação; Noções de sociologia educacional, Noções de didática especial, Noções de administração escolar, Manual do professor secundário, Orientação psicológica da criança, Noções de psicologia experimental, Noções de psicologia da criança, Noções de psicologia ado adolescente, Noções de psicologia da aprendizagem, Noções de psicologia aplicada, Grandes mestres da pedagogia moderna, Grandes mestres da psicologia moderna, Dicionário de pedagogia moderna (informações constantes em Manual do professor primário (6a . ed., 1962)" (SILVA, 2018, p. 310). Ruy de Ayres Bello escreveu Introdução à Psicologia Educacional, cuja segunda edição é de 1964, e também é autor de Finalidade em Educação (1939); Introdução à Pedagogia (1941); Esboço de História da Educação (1945); Notícia Histórica da Educação no Brasil (1946); Filosofia Pedagógica (1946); Grandes Educadores (em colaboração com Cruz Costa; Antônio D’Ávila e Damasco Pena, 1949); Pequena História da Educação (1962) e Princípios e normas da educação escolar (1962)(BELLO, 1962).
} 
francês, espanhol e alemão, o que evidencia que os autores eram conhecedores da produção científica internacional no campo da psicologia, a qual se empenharam em traduzir, sistematizar e adaptar para uso dos futuros professores. A propósito, nas páginas iniciais da terceira edição do Compêndio de Psychologia, Henrique Geenen (1925, Prefácio, s.p.) declarava:

Fui obrigado a ler sobre o assunto livros em alemão, em francês, inglês, espanhol, italiano, em holandês, até em grego e latim, pois a literatura psicológica portuguesa é paupérrima; Franco da Rocha, Julio de Mattos, Alves dos Santos, Farias de Vasconcelos, Farias de Brito, o nebuloso Coimbra, Medeiros e Albuquerque, enfim, algumas traduções e, ponto final.

Já se disse que muitos autores foram principalmente comentadores das obras dos psicólogos consagrados e estavam distantes da criança, objeto privilegiado da ciência psicológica que professavam. Mas houve também aqueles que, além de professores, eram pesquisadores em atividade nos laboratórios de psicologia experimental associados às escolas normais, em clínicas de orientação infantil ou, mais recentemente, pós-graduados que realizaram suas pesquisas na universidade. Nesses casos, sua posição não foi principalmente de intermediários entre uma bibliografia mais ou menos vasta sobre a psicologia e os professores em formação. Suas publicações não assumiram a forma estrita de manuais de ensino, embora tenham sido dirigidas aos responsáveis pelos cuidados e a educação das crianças - não apenas os professores, mas também pais e psicólogos. Esse foi o caso de Lourenço Filho, que esteve à frente do Laboratório de Psicologia da Escola Normal de São Paulo, onde formulou os testes $\mathrm{ABC}$ para avaliação da maturidade dos alunos para o aprendizado da leitura e da escrita. Além de professor e pesquisador, Lourenço Filho teve uma trajetória excepcional, tendo percorrido diversos cargos da administração do ensino no país: foi Diretor Geral da Instrução Pública em São Paulo, diretor do Instituto de Educação do Distrito Federal, presidente da Associação Brasileira da Educação, diretor geral do Departamento Nacional de Educação do Ministério da Educação e da Saúde, e ainda organizou e dirigiu o Instituto Nacional de Estudos Pedagógicos, onde criou a Revista Brasileira de Estudos Pedagógicos (CATANI, 2018, p. 102-103).

Além das bibliotecas e das salas de aula, esses autores frequentavam laboratórios, clínicas ou escolas da rede pública, espaços onde estavam as crianças que tomavam como objetos de suas observações e de seus experimentos. Eles tornaram acessíveis aos futuros professores um tipo de livro que não correspondia ao programa oficial a ser seguido nas escolas normais, mas traziam estudos de casos por meio dos quais pretendiam apresentar aos leitores a 
"realidade" das crianças brasileiras. Mesmo nesses casos, houve quem relativizasse a autoria própria, pretendendo apenas descrever a experiência de uma clínica, de um serviço etc., como é o caso de Isabel Adrados, que atuou como coordenadora e supervisora do Serviço de Psicologia Aplicada do Instituto de Psicologia da U.F.R.J., para quem

\begin{abstract}
Existem numerosos e excelentes livros sobre Psicologia Infantil, mas falta ao psicólogo bibliografia sobre a complexa dinâmica do estudo de casos. Escrevemos sobre esse assunto sem nenhuma pretensão a não ser a de ajudar, com nossa experiência de vinte anos de trabalho em Psicologia Aplicada, àqueles que se iniciam nesse campo (ADRADOS, 1983, p. 12).
\end{abstract}

Os discursos da psicologia transmitidos aos professores em formação proliferaram atendendo a dois conjuntos de exigências, um constituído pelas normas dos programas dos cursos de formação docente, outro pelo sistema de formação do discurso da própria psicologia. Sendo assim, apesar da diversidade dos livros e das transformações observadas no decorrer do século XX, identificam-se regularidades nos manuais, quanto à formação dos objetos, das modalidades enunciativas, dos conceitos e dos temas e teorias que indicam o seu pertencimento à mesma formação discursiva.

Segundo Foucault, a disciplina constitui um dos princípios de controle dos discursos, ao lado do autor e do comentário. No âmbito de uma disciplina, a validade das definições, das técnicas, dos procedimentos não está, em princípio, associada ao nome de um autor, mas à observância de suas próprias regras. O discurso da disciplina pretende ser "anônimo" e, ao contrário do comentário, sua função não é repetir e fixar o que já foi dito, mas abrir caminho para proposições novas. Contudo, conforme Foucault, "há mais; e há mais, sem dúvida, para que haja menos" (2010, p. 25), porque nem toda proposição verdadeira sobre um objeto será admitida como pertencente ao discurso da disciplina. As regras de uma disciplina, as quais são continuamente reatualizadas, exercem também um controle estrito sobre a produção dos discursos. Nas palavras de Foucault, "É sempre possível dizer o verdadeiro no espaço de uma exterioridade selvagem; mas não nos encontramos no verdadeiro senão obedecendo às regras de uma 'polícia' discursiva que devemos reativar em cada um de nossos discursos" (FOUCAULT, 2010, p. 35). A propósito, deve-se considerar que são complexas e mutáveis as relações entre autoria e verdade. O autor observou que

Houve um tempo em que textos que hoje chamaríamos 'literários' (narrativas, contos, epopeias, tragédias, comédias) eram recebidos, postos em circulação e valorizados sem que se pusesse a questão da autoria; o seu anonimato não levantava dificuldades, a sua antiguidade, verdadeira ou suposta, era uma garantia suficiente. Pelo contrário, os textos que hoje chamaríamos científicos, versando a cosmologia e o céu, a medicina e as doenças, as ciências naturais ou a geografia, eram recebidos na Idade 


\begin{abstract}
Média como portadores do valor de verdade apenas na condição de serem assinalados com o nome do autor. 'Hipócrates disse', 'Plínio conta' não eram, em rigor, fórmulas de um argumento de autoridade; eram indícios que assinalavam os discursos destinados a serem recebidos como provados. No século XVII ou no XVIII produziuse um quiasma; começou-se a receber os discursos científicos por si mesmos, no anonimato de uma verdade estabelecida ou constantemente demonstrável; é a sua pertença a um conjunto sistemático que lhes confere garantias e não a referência ao indivíduo que os produziu. Apaga-se a função autor, o nome do inventor serve para pouco mais do que para batizar um teorema, uma proposição, um efeito notável, uma propriedade, um corpo, um conjunto de elementos, uma síndrome patológica. Mas os discursos 'literários' já não podem ser recebidos se não forem dotados da função autor: perguntar-se-á a qualquer texto de poesia ou de ficção de onde é que veio, quem o escreveu, em que data, em que circunstâncias ou a partir de que projeto (FOUCAULT, 1992, p. 48-49).
\end{abstract}

Ele reconhece que entre esses dois polos há uma série de situações intermediárias, como é o caso da biologia, da medicina e também da psicologia, regiões do discurso em que a referência ao autor e à data do texto não se destinam meramente a informar a fonte, mas proporcionam fiabilidade ao discurso. A psicologia educacional é certamente um caso intermediário e, no que se refere ao discurso dos manuais, como já foi dito, é importante o fato de que seus autores escreveram muitas vezes como comentadores, como intermediários entre os autores de referência e os seus leitores. Nesses casos, a garantia de verdade dos enunciados não estava principalmente no autor do livro, mas era dada por Dewey, Claparède, Binet, Piaget e os outros autores reconhecidos como referências na psicologia. Contudo, isso não significa que o nome do autor fosse irrelevante, porque, em função de sua inserção institucional, um professor-autor pode ter sido ou não reconhecido como alguém em condição de se pronunciar sobre a obra dos especialistas consagrados.

Nas primeiras décadas do século XX, predominava entre os livros a estrutura correspondente a de um curso, cada capítulo correspondendo aproximadamente ao conteúdo de uma aula. Até a década de 1930, pode-se identificar uma estrutura típica dos manuais, com diversos deles seguindo aproximadamente o mesmo roteiro: a introdução, dedicada à apresentação da psicologia, sua história e seus métodos de investigação; um capítulo dedicado à base orgânica dos fenômenos psíquicos ou ao estudo das sensações; uma quantidade variável de capítulos para a descrição dos fenômenos psicológicos da afetividade, inteligência e vontade, incluindo-se, em alguns casos, um capítulo dedicado à linguagem e outro à criança anormal e um capítulo final para a explanação do caráter e da personalidade, entendidos como síntese dos elementos anteriores. A partir dos anos 1930, surgiram capítulos dedicados ao desenvolvimento e à influência da hereditariedade e do meio em seu curso. A psicologia era considerada uma ciência nova, recém separada da filosofia e que se situava entre a biologia e a sociologia, "como uma ponte de passagem ligando as duas" (OLINTO, 1934, p. 11). Nesse 
período tornaram-se mais frequentes as referências às aplicações pedagógicas dos conhecimentos psicológicos, que passaram a ocupar mais espaço nesses livros. A psicologia era a disciplina que forneceria bases científicas para as práticas educacionais:

\begin{abstract}
Estudando os diversos fatores da personalidade, acompanhando-a, principalmente através da evolução física e mental do indivíduo, nos primeiros anos de sua vida, especulando as causas capazes de alterá-la, a psicologia representa, neste caso, o mais sólido apoio da pedagogia hodierna, pois oferece a esta última o ensejo de propor-se dirigir a formação da personalidade infantil, segundo princípios baseados no rigor de leis científicas (PIMENTEL, s.d., p. 11).
\end{abstract}

Examinando-se os capítulos dos manuais dedicados à descrição do desenvolvimento infantil, verifica-se que o tema da hereditariedade versus meio foi central na formulação dos enunciados. Até a década de 1960, esse tema frequentemente foi tratado a partir da perspectiva da teoria da recapitulação, cuja afirmação fundamental, formulada inicialmente no campo da biologia, expressa-se no enunciado segundo o qual "A ontogênese reproduz a filogênese", o que quer dizer que cada indivíduo atravessa uma série de estágios, que correspondem à forma adulta de seus antepassados na sequência evolutiva. No manual Psicologia (1934), por exemplo, lê-se: "E cada um repete, nos limites de suas possibilidades, o esforço que empregou a humanidade na sua socialização, pois é sabido que o indivíduo refaz, abreviadamente, a marcha geral da evolução da espécie" (OLINTO, 1934, p. 254). Esse princípio foi empregado para explicar diversos aspectos do desenvolvimento, desde a forma e o tamanho do cérebro até a evolução da linguagem e da moral, e levou os autores a aproximarem o comportamento da criança ao do homem primitivo e do deficiente mental. Afirmava-se o paralelismo entre o desenvolvimento da criança e a história da humanidade, ambos pensados a partir da perspectiva moderna, evolutiva e progressista, como se verá de maneira mais detida no capítulo cinco. A possibilidade de conhecer as leis do desenvolvimento infantil associava-se no discurso dos educadores escolanovistas à afirmação de que uma educação cientificamente fundamentada permitiria orientar o futuro da humanidade. Como consequência, recomendava-se que a educação da criança acompanhasse de perto a história da civilização, conduzindo-a do estágio da inteligência selvagem ou primitiva à condição de adulto racional e civilizado:

Entre os termos do mesmo processo de evolução - experiência infantil e conhecimento da humanidade - não deverá haver oposição. O que será preciso é que a criança vá sentindo a necessidade do conhecimento organizado, e que ele signifique, ao ser aprendido, alguma coisa de sua própria experiência real. Em consequência, o programa deverá obedecer a um plano de evolução dos interesses, a um plano genético, não a um plano lógico abstrato (LOURENÇO FILHO, 1930, p. 15). 
Na década de 1960, alcançou grande sucesso o manual Psicologia educacional (1969), de Afro do Amaral Fontoura, obra em dois volumes, o primeiro dos quais era dedicado à exposição do desenvolvimento infantil nas diferentes etapas, organização que se tornaria recorrente em manuais posteriores. Dessa época em diante, as publicações se diversificam e começam a aparecer obras que consistem em coletâneas dos trabalhos realizados por pesquisadores em psicologia educacional no país, evidenciando a consolidação institucional da disciplina. Esse é o caso de Psicologia educacional e desenvolvimento humano (1972), de Iva Waisberg Bonow, que reúne contribuições de um grupo de professores da disciplina formados no Instituto de Educação do Rio de Janeiro no decorrer dos anos 1940 a 1960. É também o caso de Psicologia educacional: contribuições e desafios (1979), idealizado pela professora Juracy Marques, da Universidade Federal do Rio Grande do Sul. Para compô-lo, a autora convidou professores doutores com produção expressiva em psicologia educacional de diferentes centros de pesquisa do país.

Nos anos 1980 observa-se uma diversificação ainda maior de formato e conteúdo dos livros de psicologia dados a ler nos cursos de formação de professores, muitos dos quais se afastam da forma manual de ensino. Enquanto alguns livros dão continuidade ao modo tradicional de exposição da matéria, com uma tendência a privilegiar os temas da aprendizagem e do desenvolvimento, outros se afastam da forma de manual e organizam-se de outras maneiras. Surgem livros que correspondem à publicação de teses e dissertações, parte das quais realizadas a partir de uma perspectiva crítica em relação aos discursos dominantes na área, como por exemplo Psicologia educacional: análise crítica (FERREIRA, 1987), que se fundamenta no materialismo histórico. Entre esses destaca-se a coletânea Introdução à psicologia escolar (1997), organizada por Maria Helena Souza Patto. Embora tenha sido elaborada a partir da experiência da autora no ensino da disciplina Psicologia Escolar e Problemas de Aprendizagem, para o curso de graduação do Instituto de Psicologia da Universidade de São Paulo, o livro tornou-se referência recorrente na bibliografia das disciplinas de psicologia ensinadas nos cursos de pedagogia, ao menos nas universidades paulistas. Da mesma autora, cabe mencionar ainda A produção do fracasso escolar: histórias de submissão e rebeldia (1990), pelo seu impacto no discurso educacional e sua repercussão na formação dos professores. Em artigo publicado em 2011 sobre a trajetória dessa obra, José Sérgio Carvalho observou que a obra se tornou "referência permanente em concursos públicos para o magistério; tornou-se bibliografia recorrente de cursos de graduação e pós-graduação e 
tem sido um constante elemento desencadeador de novos estudos e pesquisas" (CARVALHO, 1989, p. 570).

$\mathrm{Na}$ produção de livros destinados à formação docente no campo da psicologia educacional a partir da década de 1990, identifica-se um conjunto significativo de livros autorais e coletâneas que tratam de temas do cotidiano escolar. Em vez de se dedicar à divulgação das teorias psicológicas, esses trabalhos incidem diretamente sobre questões enfrentadas no dia a dia da escola, frequentemente privilegiando o exame das relações de poder no interior da instituição. No âmbito dessa produção destaca-se a coleção Na escola, da editora Summus, que reúne coletâneas organizadas por Julio Groppa Aquino, professor da Faculdade de Educação da Universidade de São Paulo, sobre os seguintes temas: indisciplina, erro e fracasso, sexualidade, diferenças e preconceitos, drogas, transtornos emocionais, autoridade e autonomia. O mesmo autor escreveu Confrontos na sala de aula (1996) e Do cotidiano escolar: ensaios sobre a ética e seus avessos (2000). Outros exemplos de livros que têm como objeto o cotidiano escolar são Relações de poder no cotidiano escolar (1995), de Lúcia Maria Gonçalves de Resende, professora da Faculdade de Educação da Universidade Federal do Paraná; O cognitivo, o social e o afetivo no cotidiano escolar (1999), de Fermino Fernandes Sisto, professor da Faculdade de Educação da Universidade Estadual de Campinas; Afetos manifestos na sala de aula (2005), de Maria de Lourdes Soares Ornellas, professora do Departamento de Educação da Universidade do Estado da Bahia e Cenas do cotidiano escolar: conflito sim, violência não (2008), de Izabel Galvão, que foi professora da Faculdade de Educação da Universidade de São Paulo.

Mesmo considerando-se a diversificação dos livros nas últimas décadas do século XX, pode-se identificar um outro conjunto expressivo de livros, seja pela quantidade de títulos publicados, seja pelo número de edições alcançadas por boa parte deles, seja pela frequência com que aparecem nos programas de psicologia da educação nos cursos universitários de pedagogia e licenciaturas. Constitui-se de trabalhos dedicados à exposição de uma ou mais teorias psicológicas ou psicogenéticas e suas implicações para a educação escolar. Alguns deles tiveram muitas edições, como Psicologia da Educação, de Iris Barbosa Goulart, professora da Faculdade de Educação da Universidade Federal de Minas Gerais, com 21 edições. Destacamse nesse conjunto títulos que apresentam entre 90 e 140 páginas apenas, os quais não pretendem cobrir todo o conteúdo de um curso universitário de psicologia da educação, mas apresentar uma introdução a um ou mais autores de referência para as teorias do desenvolvimento. Esse é o caso de Piaget-Vygotsky-Wallon: teorias psicogenéticas em discussão, que já conta com 26 
edições e foi escrito em colaboração pelos professores Yves de la Taille, do Instituto de Psicologia (IPUSP), Marta Kohl de Oliveira e Heloysa Dantas, da Faculdade de Educação da Universidade de São Paulo (FEUSP). Escritos também por professoras da área de psicologia da FEUSP, Vygotsky: uma perspectiva histórico-cultural da educação, de Teresa Cristina Rego, teve 25 edições e Henri Wallon: uma concepção dialética do desenvolvimento infantil, de Izabel Galvão, 23 edições. Nesses livros identifica-se um novo modo de ser do discurso dado a ler nos cursos de formação docente, no qual a psicologia deixa de ser considerada como fundamento científico da educação e passa a ser apresentada como um conjunto de "teorias", "perspectivas" ou "concepções" sobre o desenvolvimento, que podem contribuir para formar o pensamento dos professores sobre as questões educacionais, mas já não pretendem revelar a verdade sobre o desenvolvimento e a aprendizagem da criança. No livro Psicologia da Educação (2000) escrito por Marcus Vinícius da Cunha, professor do curso de pedagogia da USP em Ribeirão Preto, afirma-se que as teorias psicológicas correspondem cada uma a um paradigma a orientar o pensamento e a conduta científica:

Cada área científica tem seus paradigmas, cada qual aceito por uma parcela da comunidade de pesquisadores. Em nosso caso, consideramos que o campo da psicologia é formado por vários paradigmas, entre os quais se destacam a psicanálise, criada por Freud, o comportamentalismo, elaborado por Pavlov, Watson e Skinner, e a psicologia genética de Piaget. Essas teorias são paradigmas porque introduziram concepções inovadoras a respeito do ser humano e conseguiram a adesão de significativas parcelas da comunidade de cientistas (CUNHA, 2000, p.8).

Passou-se a considerar que a psicologia consiste em uma dispersão de teorias, cuja contribuição para os professores era "ajudar a pensar" sobre a educação e as situações vividas na escola, mas não um conjunto de regras exaustivas capazes de assegurar o sucesso do ensino. Nos textos introdutórios desses livros, é recorrente o enunciado segundo o qual não se pretende fornecer "receitas" para o trabalho do professor. Nos discursos mais recentes encontra-se ainda a ideia de que o conhecimento não se apresenta nunca acabado, mas está sempre em processo de elaboração e reformulação. Como decorrência, o professor é encorajado a se tornar um investigador da própria prática, a assumir uma atitude reflexiva sobre o seu cotidiano e o contexto em que atua. 
Procurou-se neste capítulo caracterizar a escrita dos manuais de psicologia educacional como uma prática regulada, recorrendo-se à perspectiva de análise do discurso de Michel Foucault delineada em A arqueologia do saber e outros textos. Buscou-se evidenciar que as regras observadas pelos autores que se dedicaram à escrita desses livros não se restringiram àquelas relativas ao uso da língua, mas incluíram outras, atinentes à formação dos objetos, às modalidades enunciativas, ao uso dos conceitos e às escolhas teóricas. Afirmá-lo não significa dizer que o discurso examinado constituiu uma tessitura homogênea e rígida a cercear a escrita e impedir qualquer transformação. A propósito, vale retomar a ponderação de Foucault (2004, p. 234) a seguir, sobre a relação entre os discursos e a iniciativa dos sujeitos:

\begin{abstract}
As positividades que tentei estabelecer não devem ser compreendidas como um conjunto de determinações que se impõem do exterior ao pensamento dos indivíduos ou que moram em seu interior como que antecipadamente; elas constituem o conjunto das condições segundo as quais se exerce uma prática, segundo as quais essa prática dá lugar a enunciados parcial ou totalmente novos, segundo as quais, enfim, ela pode ser modificada. Trata-se menos dos limites colocados à iniciativa dos sujeitos que do campo em que ela se articula (sem constituir seu centro), das regras que emprega (sem que as tenha inventado ou formulado), das relações que lhe servem de suporte (sem que ela seja seu resultado último, ou seu ponto de convergência).
\end{abstract}

Os manuais de psicologia destinados aos professores foram escritos em sua maioria por professores envolvidos com a formação docente. No início do século XX, tratava-se em geral de médicos ou advogados que haviam estudado psicologia como parte de sua formação e posteriormente lecionaram a matéria nas escolas normais. Mais tarde, ex-alunos dessas escolas tornaram-se professores da disciplina e, após a criação dos cursos superiores e de pósgraduação em psicologia no Brasil, também os psicólogos passaram a ocupar essa posição, dedicando-se ao ensino e à escrita de manuais.

Grande parte do conteúdo dos livros examinados consiste em sínteses e comentários das obras de psicólogos estrangeiros reconhecidos, embora alguns autores brasileiros, inclusive de manuais, também tenham se tornado referências frequentes em obras congêneres. Pode-se dizer, portanto, que esses intelectuais foram sobretudo lectores, alguns dos quais alcançaram também o status de auctores. Mas vários deles também atuaram como pesquisadores, tendo se envolvido diretamente com a observação e a realização de experiências com crianças, notadamente a aplicação de testes psicológicos. ${ }^{7}$

\footnotetext{
${ }^{7}$ Esse texto foi submetido à revista Educação e Filosofia, da Universidade Federal de Uberlândia, para integrar o dossiê "Intelectuais entre a educação, a ciência e a política: abordagens múltiplas".
} 


\title{
3. A EXPERTISE E A TECHNE DA PSICOLOGIA APLICADAS À INVESTIGAÇÃO DO ALUNO NA ESCOLA
}

\begin{abstract}
A técnica do teste foi a contribuição mais importante das ciências psicológicas para as tecnologias humanas na primeira metade do século XX. O teste transforma o complexo conjunto de julgamentos sociais sobre a variabilidade individual em um recurso automático e rotineiro, que faz a diferença visível e registrável. Torna-se desnecessário observar as crianças por um longo período de tempo ou comparar grandes números um com o outro nas salas de aula ou abrigos para revelar suas semelhanças e diferenças. O teste codifica, matematiza e normaliza a diferença. É um recurso técnico simples, mas que pode ser usado para realizar quase qualquer esquema psicológico de diferenciação dos indivíduos em um curto intervalo de tempo, em um espaço controlado, conforme a vontade do especialista. Ele tornou-se uma parte indispensável de qualquer programa moderno de governo das diferenças individuais (ROSE, 1999, p. 143, tradução minha) ${ }^{8}$.
\end{abstract}

Nos programas de higiene mental, a clínica de orientação infantil se tornaria o centro de uma rede preventiva e terapêutica de assistência à infância, incluindo a creche, o lar, a escola, os parques e as cortes. As crianças perturbadas ou perturbadoras dos diversos quadrantes da sociedade seriam encaminhadas à clínica: crianças atrasadas na escola, crianças nervosas, gagas, mentirosas, crianças que fugiam da escola, indisciplinadas, negligenciadas e delinquentes. Na clínica os problemas da infância seriam diagnosticados, normas de ajustamento e desajustamento seriam produzidas e refinadas, e se procederia à sua normalização. Normas de ajustamento, práticas associadas ao bom ajustamento e visões do desajustamento seriam disseminadas a partir das clínicas de volta à vida institucional e familiar (ROSE, 1999, p. 158, tradução minha) $)^{9}$.

\footnotetext{
8 "The technique of the test was the most important contribution of the psychological sciences to the human technologies of the first half of the twentieth century. The test routinizes the complex ensemble of social judgement on individual variability into an automatic device that makes difference visible and notable. One no longer has to observe children for long periods of time or compare large numbers one with another in the classroom and the asylum in order to reveal their similarities and differences. The test codifies, mathematizes, and normalizes difference. It is a simple technical device, but one that can be used to realize almost any psychological schema for differentiating individuals in a brief time span, in a manageable space, at the will of the expert. It has become an indispensable part of any modern programme for the government of individual differences" (ROSE, 1999, p. 143). 9 "The child guidance clinic provided a second institutional location for this new way of thinking about and acting upon the child and the family. In the programmes of mental hygiene, the child guidance clinic was to become a centre of a web of preventive and therapeutic child welfare embracing the nursery, the home, the school, the playground, and the courts. The disturbed and disturbing children from the various quarters of the social field would be directed to the clinic: backward children, nervous children, stammers, liars, truants, the unmanageable, the neglected, and the delinquent. In the clinic the troubles of childhood would be diagnosed, norms of adjustment, practices likely to produce adjustment, and visions of maladjustment would be disseminated from the clinics back into institutional and family life" (ROSE, 1999, p. 158).
} 
A escola faz uma série de exigências aos alunos: estudo dos conteúdos curriculares, realização das atividades propostas, pontualidade, obediência às regras estabelecidas para a ocupação dos espaços, para a expressão dos próprios desejos e pensamentos e para os modos de se relacionar com os colegas e os professores. Quando um aluno falha em atender a essas exigências e expectativas de autocontrole e desempenho, apresenta-se um problema para os educadores. Nessas circunstâncias, costuma-se recorrer aos conhecimentos da psicologia e ao auxílio dos psicólogos ou psiquiatras da infância em busca da elucidação das causas do que se considera problema e de providências para superá-lo.

No decorrer do século XX, a psicologia se tornou uma disciplina central para auxiliar os professores a administrar a conduta dos alunos em sala de aula, ao permitir fundamentar as práticas escolares em um conhecimento positivo sobre o aluno. De diferentes maneiras, a psicologia procurou auxiliar os professores a enfrentar um conjunto variado de problemas do cotidiano escolar, do mau comportamento às dificuldades de aprendizagem, do sentimento de inferioridade à falta de motivação. Neste capítulo procura-se caracterizar modos distintos de intervenção da psicologia na educação escolar, por meio da descrição dos tipos de problemas que se procurou resolver em cada caso, dos conhecimentos que se formularam para compreender suas causas e das providências imaginadas para a sua superação. Examinam-se exemplos da associação entre conhecimentos e técnicas psi destinados a investigar características psicológicas dos alunos e solucionar suas dificuldades na escola nas décadas de 1930 e 1940 no Brasil. Os dois primeiros correspondem a testes psicológicos destinados à identificação dos atributos de inteligência e personalidade dos alunos, tendo em vista a adequação do ensino às necessidades individuais. Entre os representantes internacionais ilustres da psicologia experimental que produziram testes psicológicos, deve-se mencionar Alfred Binet e Théodore Simon, criadores da escala métrica da inteligência, e Edouard Claparède, autor do livro A escola sob medida. No Brasil, destacaram-se Lourenço Filho, inventor dos Testes $A B C$, para avaliação da maturidade das crianças para o início da alfabetização, e a psicóloga russa Helena Antipoff, que se estabeleceu no país em 1929 e criou o teste As Minhas Mãos, de análise da personalidade.

Os outros exemplos correspondem às clínicas de higiene mental para o atendimento das "crianças-problema". Nesses serviços, recorria-se aos conhecimentos da psicanálise nos estudos de caso. Além da aplicação dos testes psicológicos, realizavam-se exames médicos e investigavam-se as condições de vida do aluno, por meio de visitas para a realização de observações e entrevistas com os pais e a professora. Nesses estudos pormenorizados da 
criança em seu ambiente, priorizava-se a descrição das relações afetivas familiares. No Brasil, esse modelo foi empregado, entre outros, por dois médicos que estiveram à frente dos serviços de higiene mental escolar criados no Distrito Federal e em São Paulo na década de 1930: Arthur Ramos, chefe do Serviço de Higiene Mental da Seção de Ortofrenia e Higiene Mental do Instituto de Pesquisas Educacionais do Rio de Janeiro e Durval Marcondes, chefe da Seção de Higiene Mental Escolar, subordinada à Diretoria do Serviço de Saúde Escolar do Departamento de Educação de São Paulo.

No texto "A expertise e a techne da psicologia", a partir do qual foi nomeado este capítulo, Nikolas Rose procura distinguir sua própria perspectiva de análise de três outras recorrentes na história da psicologia, às quais ele se refere como histórias das aplicações, histórias das ideias e histórias das profissões. Em vez de pensar a psicologia em termos da aplicação de uma teoria, da evolução de um conjunto de ideias ou do exercício de uma profissão, Rose (2011, p. 123) a entende como expertise e como techne e esclarece: "Uso o termo expertise para referir-me a um tipo particular de autoridade social, caracteristicamente desenvolvida em torno de problemas, exercendo um certo olhar diagnóstico, fundada sobre uma reivindicação de verdade, afirmando eficácia técnica e reconhecendo virtudes éticas humanas". Em seguida, chama atenção para três características importantes da psicologia como expertise: 1. é heterogênea, pois recorre a conhecimentos e técnicas de origens distintas, aos quais procura posteriormente conferir uma unidade na forma de um discurso coerente; 2. é generosa, no sentido de que adquire penetração social por meio da oferta de seus conhecimentos para uso de outros profissionais e atores sociais, como médicos, professores, pais, assistentes sociais etc. 3. proporciona a diversos tipos de autoridades uma simplificação das práticas relativas à gestão das individualidades e uma justificação ética para o exercício do poder, que passa a ser fundamentado no conhecimento verdadeiro sobre as características e as necessidades daqueles sobre os quais se exerce.

Ao se referir à psicologia também como techne, Rose (2011, p. 125) chama atenção para o fato de que a psicologia é mais do que um modo específico de pensar e falar sobre os indivíduos e suas relações e explica: "Uso o termo 'tecnologia' para encaminhar nossa análise em direção às formas características pelas quais as práticas se organizam de modo a produzir certos resultados em termos de conduta humana: reforma, eficiência, educação, cura ou virtude". Dentre essas práticas, o autor destaca os testes psicológicos, que tornam calculáveis aspectos da individualidade humana invisíveis na superfície do corpo, tais como a inteligência, o caráter, as aptidões naturais. Também sublinha a importância da confissão, técnica na qual 
frequentemente uma pessoa estabelece um vínculo com uma autoridade em torno da tarefa de expressar a verdade sobre si mesma, engajando-se dessa maneira num trabalho orientado para a descoberta de sua própria dimensão psicológica. Essas duas técnicas, o teste e a confissão, foram introduzidos nas escolas tendo em vista a superação de problemas de aprendizagem e comportamento dos alunos, como se procura mostrar a seguir, a partir de experiências realizadas no Brasil.

\subsection{Os testes psicológicos para a avaliação das capacidades e da personalidade dos alunos}

Já na primeira metade do século XX, o elevado índice de reprovações na primeira série do ensino primário mostrava ser um sério entrave para os sistemas públicos de ensino. Na França, em 1904, o Ministério da Educação requisitou a Alfred Binet, que ocupava o cargo de diretor do Laboratório de Psicologia da Sorbonne, que criasse um método para a identificação de crianças deficientes mentais. Pretendia-se desse modo segregá-las das crianças normais, destinando-as a programas de educação especial. Diante da solicitação, Binet elaborou um conjunto de provas que exigiam capacidades mentais distintas, tais como ordenar, compreender, inventar e criticar. Pretendeu criar um instrumento capaz de avaliar a capacidade geral do examinado para a aprendizagem. Surgia assim a primeira versão dos testes de inteligência, que nos anos seguintes passaram por uma série de adaptações e se difundiram internacionalmente.

O livro Testes para a medida do desenvolvimento da inteligência nas crianças, de Binet e Simon, foi traduzido para o português por Lourenço Filho, professor de Psicologia da Escola Normal Caetano de Campos em 1929. Além de promover a adaptação e a divulgação dos testes de inteligência no Brasil, ele formulou um conjunto original de testes psicológicos. A apresentação desse novo recurso foi feita no livro Testes ABC para verificação da maturidade necessária à aprendizagem da leitura e escrita, publicado pela primeira vez em 1933. O trabalho teve grande repercussão no Brasil e em outros países da América Latina, tendo sido traduzido e divulgado também nos Estados Unidos e na França.

Conforme Lourenço Filho, nos anos de 1928 a 1930 a taxa de reprovações no primeiro ano primário aproximava-se dos $40 \%$ na cidade de São Paulo. Esses resultados eram preocupantes para a administração escolar, porque evidenciavam o fracasso da escola em 
realizar sua função precípua de promover a alfabetização do povo. Para ultrapassar esse obstáculo, o educador formulou os Testes $A B C$, como um recurso para a classificação da população heterogênea de crianças que anualmente ingressava no sistema escolar. Elaborou oito testes para calcular a "maturidade" das crianças para o aprendizado da leitura e da escrita, cujos resultados produziam uma curva normal e criavam a possibilidade de separar os alunos em três classes homogêneas, para alunos fortes, médios e fracos. Esses testes apareciam como um recurso para uma classificação inicial que permitia prever o tempo necessário para a alfabetização de cada um dos grupos. A classe forte poderia aprender a ler e a escrever no intervalo de um semestre, o grupo médio levaria um ano para conquistar a mesma habilidade e as crianças identificadas como fracas só conseguiriam atingir esse objetivo no prazo de um ano letivo se fossem atendidas em grupos menores, onde pudessem contar com a atenção individualizada do professor. Os testes surgiam como uma tecnologia de governo que permitia criar condições mais adequadas ao ensino e evitar o desperdício de recursos públicos causado pelo excesso de reprovações na primeira série.

Os testes eram aplicados individualmente de modo que, além do cálculo do nível de maturidade, fosse possível realizar um estudo mais pormenorizado da criança, observando-se e registrando-se sua atitude geral. As oito provas destinavam-se a verificar a presença das seguintes habilidades, tidas como necessárias para o aprendizado da leitura e da escrita: 1. coordenação visual-motora; 2. resistência à inversão na cópia de figuras; 3. memorização visual; 4. coordenação auditivo motora; 5. capacidade de prolação; 6. resistência à ecolalia; 7 . memorização auditiva; 8. índice de fatigabilidade; 9. índice de atenção dirigida; 10 . vocabulário e compreensão geral (LOURENÇO FILHO, 2008, p. 57). Os testes podiam ser realizados em apenas oito minutos e prometiam simplificar a organização das turmas, tornando-a mais racional, econômica e eficiente. Sua aplicação dispensava a presença de um psicólogo, "qualquer pessoa, de satisfatório cultivo" poderia dedicar-se à tarefa, contanto que seguisse estritamente as orientações indicadas:

O que é preciso é ler atentamente este Guia de Exame e dispor-se ao trabalho com boa vontade, compreendendo o alcance das provas. O Examinador deve mostrar-se afável, acolhedor, mas sem excessos de afagos e pieguices, que também perturbam a criança. Iniciado o exame, deve cingir-se rigorosamente às fórmulas adiante indicadas. No caso de a criança não ter entendido, repetirá a fórmula, nada mais. Qualquer que seja a reação do aluno, encorajá-lo, dizendo: "Muito bem!" Não deve falar muito alto nem muito baixo, mas em tom sempre igual, clara e pausadamente. Deve evitar qualquer gesto de impaciência ou expressão fisionômica que denuncie a má impressão que, porventura, possa ir tendo da criança submetida ao exame. A regra fundamental é a de que a criança esteja à vontade, calma, interessada no trabalho, e confiante no examinador (LOURENÇO FILHO, 2008, p. 125). 
Conforme seu criador, os Testes $A B C$ destinavam-se a atacar três problemas enfrentados nas classes de alfabetização. Em primeiro lugar, permitiam classificar os alunos. Destinavam-se a identificar os alunos imaturos que, antes de serem submetidos ao ensino da leitura e da escrita, requeriam inicialmente um programa pré-escolar a ser desenvolvido nos primeiros meses do ano letivo. Serviam ainda como um diagnóstico preliminar de outros obstáculos ao aprendizado, tais como retardamento mental, problemas de visão ou audição e instabilidade emocional, os quais, uma vez identificados, sugeriam a necessidade de uma investigação mais detida do caso. O educador recomendava que se recusasse a matrícula nas escolas regulares às crianças retardadas mentais, as quais deveriam ser encaminhadas para instituições especializadas.

O segundo problema, relacionado ao primeiro, que os Testes $A B C$ permitiam solucionar era o do ajustamento do ensino às possibilidades dos alunos. Uma vez selecionadas as turmas a partir do critério da maturidade para a alfabetização, os professores estavam em condições de ajustar as atividades e as exigências ao nível da turma, de modo que cada grupo pudesse avançar tanto quanto possível, de acordo com seu próprio potencial. Tal adaptação contribuiria ainda para a manutenção da disciplina escolar, uma vez que nenhuma criança se sentiria desmotivada ao defrontar-se com dificuldades além das suas forças, nem se sentiria desinteressada pela falta de desafios. Para Lourenço Filho, os grupos homogêneos evitavam a frustração e a formação do sentimento de inferioridade entre as crianças imaturas, quando reunidas com as crianças mais precoces. Esse era um aspecto fundamental na defesa das classes selecionadas, pois os sentimentos de segurança, autoestima e confiança nos professores eram considerados pré-requisitos para o bom desempenho escolar.

Finalmente, os testes criavam condições para uma avaliação mais justa do trabalho docente. As classes homogêneas adequavam as expectativas de rendimento de cada turma ao seu nível de maturidade e, assim, tornavam possível apreciar o resultado do trabalho dos professores de maneira mais precisa. Evidenciavam as diferenças de rendimento entre classes com níveis equivalentes de maturidade, permitindo identificar as falhas dos mestres cujos alunos apresentassem rendimento aquém do esperado para suas turmas. Tratava-se, portanto, de uma tecnologia de governo destinada a melhorar o desempenho tanto dos professores como dos alunos. Como bem observou Nikolas Rose, a determinação objetiva dos atributos humanos confere à verdade uma forma técnica que legitima o tratamento diferenciado dos indivíduos no interior das instituições. Assim, a distribuição desigual dos lugares, das tarefas, das exigências, 
das punições e das recompensas pode ser justificada por sua alegada eficácia e humanidade, já que visa atender às diferenças percebidas como naturais (ROSE, 2011, p. 128).

A divulgação de conhecimentos e técnicas da Psicologia aos professores fez com que passassem a exercer sua autoridade tendo em vista a dimensão psicológica dos alunos, procurando compreender suas manifestações a partir de uma grade de classificação psicológica e avaliá-los a partir de cálculos psicológicos. Cada uma das diversas decisões que os professores deveriam tomar ao exercer sua autoridade - da quantidade de lição de casa ao tempo de recreio e à intensidade do castigo - passou a ser orientada por critérios psicológicos, simplificando o exercício da autoridade por meio da adoção de um conjunto padronizado de modos de compreender os problemas e providências para solucioná-los. E, como observou Nikolas Rose, a psicologia oferece às autoridades algo mais do que a simplificação de suas tarefas. Ao fazer com que o exercício do poder seja fundamentado nos conhecimentos verdadeiros sobre a natureza dos governados, a psicologia transforma a autoridade em uma "atividade quase terapêutica":

Com a infusão do conhecimento psi no treinamento e no credenciamento dos profissionais da conduta, emerge a possibilidade de que as decisões a serem tomadas por tais autoridades possam ser empreendidas de forma que pareçam estar de acordo com os interesses daqueles cujas vidas serão afetadas - sejam eles trabalhadores, prisioneiros, pacientes ou crianças. Essa transformação ético-terapêutica é um aspecto da força que liga as diversas autoridades à expertise psicológica e que a faz tão poderosa (ROSE, 2011, p. 132).

Ao incidir sobre os problemas sociais ou institucionais, a psicologia também os transforma. Os problemas passam a ser entendidos em novos termos. Com a difusão dos saberes psicológicos no campo educacional desde a passagem do século XIX para o século $\mathrm{XX}$, as dificuldades de aprendizado passaram a ser compreendidas como decorrentes de uma inadequação das práticas de ensino à psicologia da criança. Sendo assim, a solução não deveria ser pensada em termos da intensificação da prática ou do exercício, mas em termos da adequação das exigências às possibilidades do aluno. O mau comportamento das crianças na escola deixava de ser percebido como falta de educação e passava a ser explicado em função da degeneração moral hereditária ou desajustamento ao ambiente escolar, consequência de conflitos vivenciados no interior da família. Um aspecto importante das transformações operadas pela psicologia nos termos dos problemas diz respeito às noções de risco e prevenção. Os problemas apresentados pelas crianças na escola deixavam de ser percebidos como acidentes para ser vistos como resultados de um conjunto de circunstâncias evitáveis, de modo que se podia calcular os riscos e agir de maneira preventiva, oferecendo-se orientação aos pais 
e professores sobre como organizar a rotina e preparar a adaptação da criança à escola ou como realizar procedimentos diagnósticos para a identificação das aptidões naturais e formação de classes homogêneas, antes mesmo de qualquer ensino. A preocupação preventiva evidenciavase nitidamente na seguinte passagem de Testes $A B C$ : para verificação da maturidade necessária à aprendizagem da leitura e escrita:

A aplicação de maior alcance - do ponto de vista da organização escolar -, é a que nos leva não já à consideração do diagnóstico, mas, sim, do prognóstico. Os testes indicam a probabilidade de as crianças aprenderem a ler, mais ou menos rapidamente. Convém, assim, separá-las em grupos ou classes tão homogêneas quanto possível (LOURENÇO FILHO, 2008, p. 83).

Finalmente, é importante realçar o fato de que as transformações operadas pela psicologia nos termos dos problemas produzem alterações nas relações que as pessoas estabelecem consigo próprias e com os outros ou, como diz Nikolas Rose (2011, p. 135), a psicologia infiltra-se nas "práticas éticas dos indivíduos":

As técnicas psicológicas introduziram, dominaram e substituíram aqueles regimes teológicos, morais e corporais de dietas - entre outros - que visavam conduzir o self à virtude ou à felicidade, e também aqueles direcionados a reconciliar o self com a tragédia e a decepção.

Entre essas técnicas, sobressai a da confissão, que se tornou central para a psicologia. Com a difusão dos conhecimentos da psicologia na formação dos professores e na organização do trabalho escolar, ouvir o aluno, conhecer seus desejos, medos e interesses, bem como entrevistar a família para conhecer a história da criança e as condições do ambiente em que vive tornaram-se tão ou mais importante do que ensinar-lhe os conteúdos escolares. É preciso ter em vista, contudo, que ouvir o aluno e a família não é simplesmente levá-los a expressar a sua individualidade, mas ensiná-los a falar de uma determinada maneira, empregando um certo vocabulário, manifestando seus anseios em termos compreensíveis para os especialistas, sempre prontos a oferecer um modo mais preciso de traduzir os seus pensamentos e sentimentos mal articulados. Assim, as técnicas de confissão não criam apenas uma ligação entre um indivíduo e uma autoridade baseada num vínculo de respeito ou confiança, mas estabelecem uma relação a partir da qual o sujeito constitui a si próprio, tomando-se como alguém dotado de um "interior psicológico" a ser conhecido, a partir das categorias ofertadas pela psicologia, por meio da interlocução com uma figura de autoridade. Para Nikolas Rose (2011, p. 137):

Na minha perspectiva, não se trata de descobrir o que as pessoas são, mas de diagnosticar o que elas consideram que são, os critérios e padrões pelos quais se 
julgam, as maneiras pelas quais interpretam seus problemas e problematizam sua existência, as autoridades sob cuja égide tais problematizações são conduzidas - e suas consequências. Se nós nos tornamos seres profundamente psicológicos, isso teria se dado, então, não por termos sido equipados com uma Psicologia, mas porque passamos a pensar, julgar, consolar e reformar a nós mesmos de acordo com normas psicológicas de verdade.

No início da década de 1940, a psicóloga Helena Antipoff, professora da Escola de Aperfeiçoamento Pedagógico de Belo Horizonte, desenvolveu o teste psicológico As Minhas Mãos, criado a partir do recurso pedagógico das redações, atividade tipicamente escolar. A autora considerava que as redações poderiam ser aproveitadas como um "método natural", de acordo com a designação do psicólogo russo Lazursky, para o estudo da personalidade dos alunos. O valor das redações como meio de acesso ao "fond d'esprit" fora reconhecido inclusive por Alfred Binet, que recorrera às redações realizadas por suas duas filhas para comparar suas personalidades. Para Helena Antipoff as redações podiam ser empregadas como instrumento de avaliação psicológica dos escolares, desde que realizadas de maneira controlada, de modo a permitir um julgamento objetivo:

O método da experimentação natural, aplicado à redação, repousa num estudo preliminar de condutas individuais, que leva à descoberta de elementos característicos para a análise da prova. O cômputo numérico de seus elementos permite o levantamento de quadros padronizados, relativos a um número suficiente de pessoas. O confronto dos resultados individuais, com as normas obtidas, oferece ao psicólogo meios mais objetivos para o julgamento da redação e, portanto, de seu autor (ANTIPOFF, 1948, p. 319)

Uma vantagem do estudo da personalidade dos alunos por meio do método "natural" das redações escolares era a facilidade de repeti-lo de tempos em tempos, o que permitia ao educador "melhor conhecer o aluno e acompanhar a sua formação espiritual", a partir da verificação das características que se manifestavam repetidamente. A redação escolar também era conveniente no modo de aplicação, que era rápido e podia ser realizado simultaneamente com um grande número de alunos.

Ao descrever o surgimento do teste, a autora relatava que, a partir de uma série de experiências realizadas com temas distintos, optara-se pela "descrição de objetos". E que "entre os objetos estudados, nada nos pareceu mais sugestivo que as mãos" (ANTIPOFF, 1948, p. 320). A partir desse tema, outras experiências haviam sido realizadas; até que se chegasse à formulação definitiva:

Esse tema, por sua vez, foi objeto de estudos detalhados em suas diversas variantes a saber: "minha mão esquerda", "meus polegares". "As mãos". "As minhas mãos". Cada um dos temas refletindo de preferência um ou outro caráter individual, foi 
finalmente adotado este último tema, por serem mais ricas e mais variadas as “condutas" individuais por ele suscitadas (ANTIPOFF, 1948, p. 320).

A primeira divulgação do teste ocorreu em 1943 nas "Jornadas Psicológicas” de Belo Horizonte. Em 1948 foi apresentado no artigo "Teste de redação", publicado na Revista Brasileira de Estudos Pedagógicos. Nesse texto, apresentavam-se as instruções para a realização do teste, destinado a indivíduos que contavam com pelo menos 6 ou 7 anos de escolaridade e já escreviam com fluência. Em seguida, apresentava-se a forma de apuração dos resultados, listando-se doze procedimentos que incluíam a contagem do número de palavras, para medir a extensão do texto; a divisão do número total de palavras por minutos, que indicava a fluência da redação e a contagem das porções de sentido, atribuindo-se "a cada uma equivalência psicológica" (ANTIPOFF, 1948, p. 321). A análise incluía ainda a "determinação de caráter pessoal ou extrapessoal, de cada porção de sentido" (ANTIPOFF, 1948, p. 321). Finalmente, o artigo apresentava exemplos de redações realizadas e os resultados correspondentes. A partir da redação realizada por um menino de 13 anos, produzira-se a seguinte análise:

\footnotetext{
O autor da redação revela nível escolar relativamente comum para sua idade e meio social. Redige com certa facilidade, pois em 10 minutos escreve 90 palavras, o que lhe dá uma fluência alcançando o percentil 80.

Possui certa vivacidade intelectual e procura ordenar seu pensamento, o que se pode inferir da divisão dos parágrafos que faz questão de por bem em evidência, iniciandoos a boa distância da margem esquerda.

Respeita a margem direita, dada pela instrução do teste, não transgredindo uma vez sequer a linha divisória (obediência à regra).

A estrutura mental não é rígida, equilibrando-se bem a parte pessoal e a geral. Entretanto faltam elementos perceptivos, imaginativos e afetivos. Predominam os elementos de memória e de julgamento subjetivos. Os gerais revelariam uma tendência ao pedantismo escolar, enquanto os pessoais denotam espontaneidade. Os elementos lógicos são poucos, apenas 3, ou seja percentil 35, e são de caráter explicativo e de inferência (um pouco de pedantismo)

O egocentrismo da redação é normal para a idade (percentil 45) mas a tendência seria maior se consultássemos o grafismo do escritor: o nome próprio escrito com letras muito maiores que o resto do texto.

Notaremos também tendência narcisística da maneira com que se refere às suas próprias mãos ("limpinhas"), suas unhas ("bem tratadinhas"). Este emprego dos diminutivos relativos à própria pessoa, assim como a menção de usar anel na hora de sair, revelaria talvez (para menino de 13 anos) um caráter afeminado. Deveria ser observado mais perto para receber uma orientação oportuna (ANTIPOFF, 1948, p. $332)$.
}

$\mathrm{O}$ teste As Minhas Mãos, assim como os Testes $A B C$ evidenciam que a escola constituiu campo fértil para o desenvolvimento da psicologia. Criou tanto um conjunto de problemas relativos à administração da diversidade humana, quanto condições para a 
realização de experiências controladas com populações de alunos, funcionando como laboratório para a formulação e a aplicação de seus conhecimentos, procedimentos e técnicas.

A transformação da redação escolar em teste psicológico exigiu o controle mais estrito da atividade, especialmente no que diz respeito às instruções fornecidas aos alunos para a sua realização e ao limite de tempo estabelecido para completá-la, de modo a tornar os resultados obtidos em cada aplicação comparáveis aos parâmetros estabelecidos. A redação como modo de expressão da personalidade passou a ser avaliada a partir de novos critérios quantitativos e qualitativos, estabelecidos de antemão. Uma análise minuciosa de sua forma e conteúdo tornou possível identificar capacidades e aspectos da personalidade tão diversos quanto obediência às regras, lógica, imaginação, narcisismo, equilíbrio entre elementos objetivos e subjetivos na descrição de objetos e até mesmo levantar uma suposição acerca da orientação sexual do autor. Avaliada desse modo, a redação escolar tornava-se para o psicólogo e o professor uma via de acesso à personalidade do aluno e um meio de identificar eventuais problemas.

\subsection{A "observação poligonal" e " em profundidade" ou o estudo "múltiplo" dos casos de desajustamento à escola}

Exemplos do emprego da tecnologia da confissão pela psicologia dedicada à investigação dos problemas vividos na escola encontram-se nas obras A criança problema: a higiene mental na escola primária (1939), de Arthur Ramos, e Noções gerais de higiene mental da criança (1946), de Durval Marcondes. Os livros foram escritos a partir da experiência acumulada nos serviços de higiene mental escolar do Rio de Janeiro e São Paulo.

A criança problema constituiu, segundo Dante Moreira Leite, o primeiro trabalho publicado no país a oferecer um estudo empírico sobre os problemas de aprendizagem escolar (MOREIRA LEITE, 1976 Apud PATTO, 1990, p. 80). Na introdução do livro, Arthur Ramos explicava que a expressão criança-problema fora criada para distinguir as crianças anormais, portadoras de deficiências físicas, hereditárias ou não, daquelas cujas dificuldades enfrentadas na escola eram associadas à inadequação do ambiente familiar, em especial às relações conflituosas com os pais, que não as compreendiam:

Logo se verificou que uma enorme percentagem de crianças classificadas como 'anormais', não eram portadoras de nenhuma anomalia mental, mas sofriam a ação das causas extrínsecas. Para que então continuar chamando de 'anormais' a essas pobres crianças vítimas da incompreensão dos adultos, do seu meio, da sua família, da escola? Como veremos nas páginas deste livro, muitos casos classificados mesmo 
como de atraso mental, são realmente falsos atrasos, como os "atrasados afetivos" a que tanto se refere Gilbert-Robin. As crianças "caudas de classe" nas escolas, insubordinadas, desobedientes, instáveis, mentirosas, fujonas... na sua grande maioria não são portadoras de nenhuma "anomalia" moral, no sentido constitucional do termo. Elas foram "anormalizadas” pelo meio (RAMOS, 1939, p. XVII).

Ao assumir o comando do Serviço de Higiene Mental e Ortofrenia da Secretaria da Educação do Rio de Janeiro, o especialista criara um conjunto de clínicas destinadas à investigação dos escolares, dentre as quais clínicas de hábitos nos jardins de infância dedicadas ao estudo das crianças normais e à orientação das famílias de modo a prevenir os desajustamentos; clínicas ortofrênicas vinculadas às escolas municipais para o estudo, a prevenção e a correção dos desajustamentos. Expandiam-se as instituições e, simultaneamente, os saberes sobre os desvios de conduta e personalidade. Ao privilegiar a dimensão preventiva em relação à corretiva, a psicologia alargou o seu campo de investigação, que passou a abranger não apenas o indivíduo desviante, mas também a personalidade normal, em busca de sinais de desajustamento antes que o problema chegasse a se instalar. O privilégio concedido pela higiene mental à criança explicava-se também pela sua missão precípua de prevenção. Nas palavras de Arthur Ramos (1939, p. XX):

Desde cedo se verificou que estava na infância o principal campo de ação da higiene mental. Se esta visa a prevenção das doenças mentais e o ajustamento da personalidade humana, é para a criança que deve voltar suas vistas, pois aí estão os núcleos de caráter da vida adulta.

Na introdução do livro A criança problema, o autor criticava a "extrema atividade 'testologizante' que vinha atravancando a pedagogia da época” (RAMOS, 1939, p. XV). Ponderava que as dificuldades apresentadas pelos alunos na escola eram fenômenos complexos, que não podiam ser adequadamente explicados por testes e cálculos estatísticos. Em outro livro de sua autoria, Educação e Psicanálise (1934), Ramos (1934, p. 82-83) manifestava a convicção de que a identificação das aptidões intelectuais era insuficiente para a compreensão dos problemas de adaptação da criança à escola:

Os pedagogos - e é a crítica de Jones em seu estudo sobre o inconsciente da criança - são levados geralmente a classificar os escolares em duas categorias: os que possuem aptidões intelectuais e os que não as possuem. Esquecem o dinamismo emocional subjacente. Esquecem o papel formidável do inconsciente, verdadeiramente o motor das ações humanas. As inibições intelectuais estão aí patentes, todos os dias, até na compreensão do mais simples silogismo quando há uma causa emocional atual ou remota. Todos os testes de inteligência fracassarão aqui redondamente. Nos casos pedagógicos mais complexos, nesta multidão de "difíceis" escolares, e principalmente quando há defeitos mais graves de caráter, então a psicanálise, só ela, poderá resolver a situação, mostrando a decisiva influência que têm os acontecimentos da vida infantil, principalmente no domínio da sexualidade, em todos os atos da vida humana, na família, na escola e na sociedade. 
Se os problemas de aprendizagem não eram necessariamente decorrentes da falta de capacidade, mas podiam estar relacionados a uma trama complexa de fatores relativos às condições de vida da criança e à sua história pregressa, da perspectiva da higiene mental o recurso da seleção de classes nas escolas primárias não deveria ser generalizado, mas adotado com bastante cautela e apenas nos casos de verdadeira anormalidade:

[...] a higiene mental da criança-problema reage à instalação sumária e aligeirada de "classes de anormais", ou de "classes de difíceis", para a educação "especial" destas crianças. Isto deve ser reservado para o caso dos escolares diagnosticados realmente "atrasados constitucionais" (RAMOS, 1939, p. 417).

No Serviço de Ortofrenia e Higiene Mental procedia-se a diversas avaliações pormenorizadas, tendo em vista a produção de um estudo de caso completo de cada criança, incluindo a descrição das condições físicas e emocionais do ambiente onde vivia e os resultados de exames médico-orgânicos e neuropsicológicos, que permitissem avaliar a saúde do aluno. Recorria-se a um método de observação poligonal, caracterizado nos seguintes termos:

Em nosso serviço, não damos preferência exclusiva a qualquer método. Recorremos a métodos combinados, ou a métodos especiais, conforme o caso: observação incidental, fragmentos biográficos, observação sistemática, questionário, história de casos, testes e medidas, experimentação etc. É, porém, o método clínico, que reúne a maior soma de processos de investigação da personalidade, o mais comumente empregado por nós. Poderemos chamá-lo de método de observação "poligonal", pois ele se utiliza de todos os dados de observação da criança fornecidos pelo professor de classe, pelos pais etc., tudo isso devidamente controlado pelo pessoal técnico do Serviço (RAMOS, 1939, p. 23-24)

Depois da Introdução, a obra A criança problema está organizada em três partes: a primeira parte é dedicada à investigação das "causas"; a segunda à caracterização dos "problemas" e, finalmente, à conclusão. Capítulo a capítulo o autor se dedica a examinar as causas dos desajustamentos escolares, iniciando por considerações gerais sobre os fatores "herança e ambiente" e passando em seguida à caracterização das relações que se estabelecem entre a criança e os seus familiares. Um capítulo é dedicado ao estudo da "criança mimada" e, em seguida, quatro capítulos são destinados à "criança escorraçada". Os temas "As constelações familiares", "O filho único" e "Avós e outros parentes" são abordados em capítulos específicos. Na segunda parte do livro, relativa à descrição dos problemas, dedicamse três capítulos aos "problemas sexuais"; dois à "criança turbulenta" e ao tema do "medo e angústia" e um capítulo a "tics e ritmias"; "as fugas escolares"; "a pré-delinquência infantil: a mentira" e "a pré-delinquência infantil: os furtos". 
O método de investigação dos casos de desajustamento no Serviço de Higiene Mental chefiado por Ramos caracterizava-se pela "observação poligonal" e "em profundidade" da criança, e ainda por recorrer aos métodos "derivados do movimento psicanalítico: escola de Freud, de Adler etc.” (RAMOS, 1939, p. XXIV). Múltiplos saberes e procedimentos, assim como o recurso a diversos informantes que viviam em torno do aluno - a mãe, a professora, eventualmente o pai ou a avó - integravam-se na produção do dossiê de cada criança-problema atendida pelo Serviço, a partir do qual se realizava o diagnóstico e se formulava uma proposta de tratamento que, na maioria dos casos, dirigia-se antes à correção do meio desajustado do que à própria criança. Nas fichas que reuniam os dados sobre cada criança, registrava-se, geralmente, o seguinte: sexo, idade e cor da criança. Nacionalidade, ocupação e características físicas e psicológicas dos pais; condições em que ocorreu a gestação da mãe; doenças ou distúrbios do crescimento, da fala, da marcha; número de irmãos, assim como a idade e o sexo de cada um; o tipo de domicílio, se próprio ou alugado, disponibilidade de aposento e cama para a criança; rotina da criança em casa (brincadeiras, tarefas, passeios, visitas habituais), horário de dormir e acordar, facilidade ou dificuldade de conciliar o sono, presença ou não de medo da escuridão ou do isolamento, eventual enurese noturna; resultado do exame para lues congênita; atitude em casa e na escola: gostos e preferências, comportamento em relação aos pais, irmãos, professores e colegas, qualidade da memória, concentração e aprendizagem. $\mathrm{O}$ exemplo a seguir ilustra o modo como se registravam essas informações:

obs. 12 (Escola 'Argentina', ficha no. 269 do S.O.H.M.).

A.R. é um menino de 9 anos, cor parda. O pai, eletricista, é alto, alegre, com tendências a cóleras frequentes: "ele bate na gente, ele dá na gente", diz o menino. A mãe é costureira, alegre, "sofre do coração". Frequenta sessões espíritas, "para endireitar a vida da família'. Informação da criança: "uma vez botaram macumba lá em casa, botaram farofa amarela". Dois irmãos, um de 20, outro de 16 anos. A.R. é o caçula e preferido da mãe.

Moram em casa alugada, em "avenida", sem acomodação para a criança, que dorme no mesmo quarto dos pais. Diversões preferidas: cinema, circo; "fita, só de avião..." Vida matrimonial: conflitos frequentes, poucas visitas em casa. "Os vizinhos da vila brigam muito por causa da água, são brigões...” Deita-se às 20 horas, levanta-se às 6; tem medo de ladrão. Brinca em casa e na escola; brinca só; quando há companheiro, tendência a dominar. Atormenta os colegas com pancadas; é fanfarrão e tagarela, embirrante, mente às vezes, vive piscando os olhos. É insociável, agitado, agressivo, irascível, desconfiado. Aprendizagem difícil. Da sua ficha: "Irrequieto, brigão, vive a provocar os colegas. Desatento, grita em classe e quando contrariado, põe-se a choramingar. Desobediente, não atende à ordem de ninguém. Canta em classe, arrasta as cadeiras, faz uma algazarra medonha. O menino é muito mimado pela mãe, que sempre lhe perdoa as travessuras, fazendo-lhe todas as vontades". O Serviço esclareceu a situação, orientando os pais na maneira de agir com a criança (RAMOS, 1939, p. 36). 
A “observação poligonal” interpretada à luz da teoria psicanalítica levava o serviço a atribuir o comportamento desajustado do menino às condutas inadequadas do pai, dado a crises de cólera, e da mãe, que lhe fazia todas as vontades. Assim, em vez de corrigir a criança, o serviço procurava "esclarecer" e "orientar" os pais, na expectativa de que a readequação das relações familiares produzisse a mudança desejada no aluno. A intervenção junto às famílias, contudo, precisava ser cuidadosa para não suscitar resistências. O autor lamentava o fracasso das tentativas realizadas no Brasil de se criar "círculos de pais", que atribuía ao narcisismo dos familiares, os quais se sentiam felizes em participar dessas reuniões apenas para ouvir elogios aos seus filhos, mas recusavam-se a reconhecer sua parcela de responsabilidade quando se tratava de discutir seus problemas de comportamento e caráter. Em outras palavras, os pais resistiam à confissão. Para contornar as resistências dos pais e a sua desconfiança em relação aos visitadores sociais, o Serviço de Ortofrenia e Higiene Mental desenvolvera sua própria estratégia de modo a conseguir exercer a sua influência:

\footnotetext{
Em nosso serviço, esta ação tem sido lenta e cautelosa. Quase sempre convidamos os paes a discutir questões de ordem puramente medico-organica dos filhos, e por ahi, insensivelmente, eles recebem os influxos benéficos do Serviço. Os resultados tem sido excelentes. A visita social, em muitos casos, completa a obra. Não essa visita, com aspectos muitas vezes antipático, interpretada pela família como uma intromissão indébita, principalmente nos lares pobres que a tomam como uma "afronta", mas uma visita cordial, aceita e muitas vezes solicitada pela própria família (RAMOS, 1939, p. 412).
}

A última parte do livro é dedicada ao tratamento e à assistência à criança-problema. Arthur Ramos considerava que o melhor era conservá-la na escola regular e realizar o seu acompanhamento pelo higienista mental e demais especialistas que pudessem contribuir para a sua recuperação: médico, psicólogo, assistente social. Em primeiro lugar, era necessário proceder ao exame físico para identificar e tratar doenças ou desvios de natureza médicoorgânica. O auxílio necessário à superação desses problemas podia ser obtido em uma série de instituições peri-escolares: os pelotões de saúde, as cooperativas e caixas escolares, as merendas e sopas escolares, as organizações de amigos da escola, os círculos de pais e professores etc. (RAMOS, 1939, p. 406). Uma vez atendidas e tratadas essas necessidades físicas imediatas, passava-se a tratar a dimensão psicológica, mais sutil. Nessa segunda etapa, era preciso procurar esclarecer e corrigir a família, o que se revelava extremamente difícil, pelas resistências já mencionadas dos pais em confessar sua participação nos problemas de comportamento apresentados por seus filhos na escola. Finalmente, procurava-se intervir no ambiente escolar. $\mathrm{O}$ autor considerava que a professora podia desempenhar um papel fundamental, por exemplo na recuperação da criança escorraçada, pois podia proporcionar-lhe 
a compreensão que a mãe não podia oferecer-lhe em seu lar desajustado. O higienista vislumbrava para a criança-problema uma educação escolar terapêutica, fundamentada na psicanálise:

\begin{abstract}
A escola completará a obra, procurando compreender a criança, não como uma entidade isolada, portadora de "vícios hereditários", de "constituições delinquenciais" e outras coisas cerebrinas, mas como um ser vacilante, afetivo, em formação, no meio de constelações afetivas dos adultos. O papel fundamental da professora, como temos de repetir tantas vezes neste trabalho, será o de se superpor aos pais sádicos, principalmente à mãe madrasta que não compreende os problemas do seu filho. A professora conseguirá da criança a "transferência afetiva" e dará assim uma compensação a uma alma órfã de afeto. A compensação afetiva dos problemas da criança é o primeiro passo para a sua correção educativa (RAMOS, 1939, p. 125).
\end{abstract}

Em A criança problema, as dificuldades do aluno são consideradas em termos de desajustamento à escola e atribuídas a conflitos vividos pela criança em suas relações familiares. A criança deixa de ser percebida como a origem do problema e passa a ser vista como a expressão da desordem em seu ambiente familiar. Nessas condições, altera-se o alvo e o sentido das providências. Já não é o caso de procurar testar e classificar crianças para a formação de grupos homogêneos, mas de investigar, a partir da observação "poligonal” e "em profundidade", as causas específicas das dificuldades vividas pelo aluno e intervir na origem do problema, invariavelmente encontrada na família.

O livro Noções gerais de higiene mental da criança (1946) tem uma organização diferente da obra A criança problema, mas apresenta um modo semelhante de investigar e de propor o tratamento das crianças consideradas problemas. Consiste em uma coletânea organizada por Durval Marcondes, chefe do Serviço de Higiene Mental Escolar de São Paulo, que reúne os textos de 15 palestras proferidas para professores paulistas pelo pessoal do serviço. Além de Durval Marcondes, autor de dois trabalhos, os colaboradores que assinavam os demais capítulos eram médicos, visitadoras psiquiátricas e psicologistas que atuavam na clínica $^{10}$. Na apresentação dos autores, evidencia-se a vinculação entre esse serviço de higiene mental escolar e a Universidade de São Paulo. As colaboradoras eram, em sua maioria, normalistas formadas pelo Instituto de Educação e/ou educadoras sanitárias pelo Instituto de Higiene da USP, com a exceção de Maria de Lourdes Verderese, normalista e diplomada em Educação pela Faculdade de Filosofia de São Bento.

\footnotetext{
${ }^{10}$ São autores os médicos Armando de Arruda Sampaio (médico internista), Joy Arruda (médico psiquiatra) e Mário Vélez, (médico psiquiatra); as visitadoras psiquiátricas Diná Mascarenhas do Amaral; Lígia Alcântara do Amaral, Oraíde de Toledo Piza, e Virgínia Leone Bicudo e as psicologistas Margarida Lisboa Vieira Cunha, Maria José de Morais Barros, Maria de Lourdes Verderese e Maria Rita Garcez Lobo.
} 
Os textos apresentam os diversos aspectos do tratamento da criança-problema, evidenciando o caráter interdisciplinar do serviço: referem-se ao "desenvolvimento psíquico do indivíduo normal”, aos "distúrbios psíquicos da criança” e ao funcionamento da clínica. Em seguida, quatro capítulos são dedicados à explicitação da função específica dos diferentes profissionais que atuavam no serviço: o médico internista, a psicologista, a visitadora psiquiátrica e o médico psiquiatra. Adiante, três capítulos destinam-se ao estudo do "papel do lar" e outros dois ao papel do "lar substituto" e ao "papel da escola e da professora" na higiene mental da criança. Há ainda um capítulo que discute o "nível de inteligência da criança e sua importância como fator de desenvolvimento psíquico" e outro que trata do papel da recreação na higiene mental da criança. Finalmente, o último, assinado por Durval Marcondes, trata do tema "A criança e a guerra".

Em vez da expressão "observação poligonal e em profundidade", empregada por Arthur Ramos, Durval Marcondes (1946, p. 44) recorria ao termo "múltiplo" para qualificar o tipo de estudo da criança realizado em seu serviço, mas o caracterizava de maneira muito semelhante ao que era descrito em A criança problema:

O fundamento da clínica de orientação infantil é o estudo "múltiplo" do casoproblema. Cada caso é nela abordado através de várias técnicas, de modo a abranger a complexidade dos fatores que participam de sua determinação. A causa de desajustamento pode residir no plano anátomo-fisiológico, no plano psicológico ou no plano social, ou ainda em todos eles ao mesmo tempo. A clínica não parte do pressuposto de que a gênese do problema está nesta ou naquela categoria de fatores. Admite a possibilidade da existência de agentes causais os mais diversos e procura determinar o papel relativo que cada um desempenha na trama etiológica.

Tratava-se também no caso desse serviço, de uma proposta que se orientava para o tratamento total: considerava-se a criança em suas dimensões física e psicológica, ao longo do seu desenvolvimento, e tanto a investigação do caso quanto o seu tratamento incidiam não apenas sobre a criança, mas também sobre o meio em que ela estava inserida: a família, a escola. Assim como em A criança-problema, de Arthur Ramos, no trabalho da equipe dirigida por Durval Marcondes privilegiava-se a prevenção dos desajustamentos em relação à sua correção, por meio de iniciativas como palestras, cursos e produção de materiais de divulgação dos princípios de higiene mental destinados aos professores. Classificavam-se os tipos de problemas de maneira análoga, como se pode verificar na listagem de Durval Marcondes (1946, p. 45), organizada em ordem decrescente de ocorrências:

1) Conduta irregular na escola (abrangendo a desobediência, a rebeldia e a indisciplina em geral); 2) furto; 3) dificuldades da aprendizagem; 4) instabilidade psico-motora; 5) mentira; 6) enurese; 7) fugas (da escola e do lar; incluindo a gazeta); 
8) problemas sexuais; 9) timidez; 10) tics; 11) sintomas histéricos; 12) fobias; 13) fantasia excessiva; 14) agressividade.

Na clínica de São Paulo, prevalecia a mesma percepção de que, na grande maioria dos casos, o problema do aluno não era devido à causa física e a mesma tendência a encontrar nas relações afetivas entre os pais e a criança a causa do desajustamento, o que redundava em um modo semelhante de retratar a criança, como se pode observar no exemplo a seguir, em que se descreve inicialmente a aluna e o seu comportamento e depois se busca explicá-lo pela rejeição dos pais em relação a ela:

\begin{abstract}
Celeste, uma escolar de 8 anos de idade, aluna do $1^{\circ}$ grau, apresenta-se na escola muito indisciplinada e agressiva, bate nas companheiras, furta objetos escolares das colegas, responde mal à professora, não para um só instante na sua carteira. Em casa, é também excessivamente agressiva, bate nas irmãs que são menores que ela, desobedece a mãe e timbra em executar ao contrário as ordens que lhe são dadas. Quando se vê obrigada a obedecer à mãe, foge para o quintal e dá gritos tão estridentes que a vizinhança fica alarmada. Vive trepada em árvores, desafiando a mãe lá de cima. Nossa primeira impressão foi a de que estávamos diante de uma criatura selvagem. Seu olhar era desconfiado e rancoroso. Ao exame psicológico, revelou dificuldade de compreensão.

A investigação social apurou, nesse caso, intensa rejeição afetiva por parte de ambos os pais. O pai não fala com a filha, não se conformando com esta ser menina, pois desejava ardentemente um filho. Contava Celeste dois meses de idade, quando o pai, importunado com o choro da menina, fê-la calar com uma vigorosa palmada. A mãe vivia em sobressaltos contínuos, pois o marido ameaçava atirar a criança pela janela. Ambos os pais infligem à filha violentos castigos físicos. À medida que Celeste cresce, a rejeição paterna toma a feição de indiferentismo, enquanto a materna aumenta. A mãe maltrata-a muito, fecha-a no galinheiro em companhia de uma cabra que lhe causa medo, manda-a à noite sozinha ao quintal, mesmo sabendo que Celeste é medrosa (AMARAL, 1946, p. 123-124).
\end{abstract}

No texto "Clínica de orientação infantil; suas finalidades, e linhas gerais de organização", Durval Marcondes expunha o procedimento de investigação do caso seguido na clínica do serviço que dirigia. O passo inicial era a "investigação social", responsabilidade da visitadora, que partia em busca da identificação das "diversas ocorrências prejudiciais" ao desenvolvimento da criança e da caracterização das condições do ambiente familiar e escolar em que ela vivia, por meio do "interrogatório sistemático dos que têm contato com a criança". Essa investigação abrangia “o estudo individual das pessoas da família (pai, mãe, irmãos etc.), em tudo que diga respeito à sua atitude para com a criança e se relacione com a formação da atmosfera psíquica do lar", assim como a descrição da rotina e das condições higiênicas em que ela vivia (MARCONDES, 1946, p. 46). Reunidas essas informações, encaminhava-se a criança para a sede da clínica, onde ela era submetida a uma série de testes psicológicos e exames médicos realizados pelos técnicos do serviço. O momento crucial dessa etapa era a 
entrevista com o médico psiquiatra, cujos objetivos e procedimentos eram descritos no livro por Mário Vélez (1946, p. 94):

\begin{abstract}
No estudo da criança-problema, o "élan" capital está na entrevista psiquiátrica. Não existem métodos estandartizados ou técnicas consagradas no exame psiquiátrico. As técnicas variam com a criança e com o psiquiatra. Algumas podem ser, por assim dizer, previamente elaboradas, ao passo que outras são improvisadas e empíricas. Além disso, o psiquiatra adquire métodos especiais que animam a criança a falar, de maneira que são realmente significativos e então aumenta a cópia de material útil para fazer suas deduções e induções. Outro valor da entrevista psiquiátrica está em deslocar a criança de seu ambiente e encorajá-la a julgar por si só suas atividades, motivos, impulsões, e outros estados d'alma. Isto traz oportunidade de observar suas maneiras, respostas, tons, tensões, ao lado do conteúdo da linguagem, que fornece indicações sobre suas ideias e emoções. Finalmente, a entrevista psiquiátrica tem seu propósito em preparar o caminho para ulteriores entrevistas, se isso for necessário.
\end{abstract}

$\mathrm{Na}$ etapa seguinte o pessoal do serviço se reunia e cada um dos especialistas apresentava as suas conclusões sobre o caso, tendo em vista propor uma "diretriz harmônica" para o tratamento. Cabia à visitadora, "peça móvel da clínica" a tarefa de levar as orientações aos pais e professores e "zelar pela sua exata observação". O caso seria ainda acompanhado em reuniões posteriores da equipe, que seguia avaliando os resultados das ações realizadas. A atuação da clínica incidia, portanto, diretamente sobre a criança, por meio do "tratamento médico e psicoterápico" e indiretamente, por meio da intervenção nas "condições ambientais que oneram o seu ajustamento" (MARCONDES, 1946, p. 47).

No capítulo "Papel da escola e da professora na higiene mental”, a psicologista Maria de Lourdes Verderese, afirmava que a professora tinha necessidade de conhecer a psicologia da criança normal e anormal e defendia a inclusão da disciplina de higiene mental na formação docente. Era preciso que ela compreendesse que cada aluno era único e demandava um tratamento individualizado. Considerava que parte das práticas realizadas na clínica poderiam ser empregadas também pela professora na escola. Recomendava que, assim como se fazia na cínica, a professora procurasse conquistar a confiança da criança; que se dedicasse a observála em suas atividades recreativas; observasse os seus desenhos espontâneos; desse atenção à sua opinião sobre outras pessoas; observasse as suas relações com a professora, tendo em vista a questão da transferência, ou seja, o fato de que o aluno tendia a reproduzir na relação com a professora as relações afetivas vivenciadas com os pais. Finalmente, aconselhava que a professora tivesse em vista a própria atitude, que muitas vezes era causa do problema de comportamento do aluno. Era preciso, em primeiro lugar, "evitar currículos e programas inadequados à etapa da evolução normal do psiquismo". Em seguida, convinha criar oportunidades de "expansões adequadas" à sublimação: "competições atléticas e outras 
atividades recreativas constituem um dos mais importantes recursos para uma derivação satisfatória de sentimentos indesejáveis" (VERDERESE, 1946, p. 138). A autora concluía defendendo o ensino em separado para os oligofrênicos bem como o encaminhamento da criança-problema à clínica de higiene mental.

Por meio da descrição de alguns exemplos do caso brasileiro, procurou-se evidenciar a dimensão técnica da produção da verdade sobre o aluno no âmbito da psicologia experimental e das clínicas de higiene mental, privilegiando-se a descrição do teste psicológico e dos procedimentos de confissão. Em cada caso, buscou-se apresentar os procedimentos de controle da coleta de informações, dos modos de descrição e quantificação dos dados, num esforço para realizar um estudo quase laboratorial da criança. As verdades produzidas a partir dos dados obtidos de maneira controlada fundamentavam as decisões dos especialistas sobre a organização do ambiente e da rotina da criança. No período considerado, em vez de corrigir a criança, defendia-se o ajustamento do ambiente familiar e escolas às possibilidades e necessidades individuais. E parte fundamental desse ajustamento dependia da orientação dada aos pais e professores sobre o razoável exercício da autoridade - nem mimar nem castigar em excesso - e sobre a adequada expressão dos afetos na relação com a criança.

A psicologia experimental baseada nos testes, ao se aproximar dos métodos das ciências naturais, privilegiou a descrição e a mensuração das capacidades do aluno, tendo em vista estabelecer sua posição em um quadro classificatório. Conforme esse modelo, o estudante poderia ser normal ou anormal e, dentro da normalidade, poderia ser forte, médio ou fraco. Essas categorias podiam ser ainda desdobradas em muitas outras, mas o objetivo era sempre o mesmo: descobrir as aptidões individuais para encontrar a posição certa para um na escola. Sob a psicanálise, o estudo do aluno tornou-se mais abrangente e aprofundado. Passou-se a considerar insuficiente classificá-lo por meio da aplicação de testes padronizados. Já não bastava medir a inteligência e outras aptidões, mas era preciso realizar uma investigação tão completa quanto possível da psicologia da criança, incluindo sua história e suas condições de vida na família, seus desejos e medos inconscientes. Daí em diante, a contribuição da psicologia para a educação deixou de ser pensada apenas em termos de discriminação e correção da 
criança anormal, mas passou a incluir uma dimensão preventiva, voltada para toda a população escolar.

Atualmente, na investigação dos problemas apresentados pelos alunos nas escolas, acrescentam-se aos (ou concorrem com os) testes psicológicos e estudos de caso, as tecnologias de ressonância magnética e tomografia computadorizada, que produzem imagens do cérebro em funcionamento. A suposição de que se tornou possível "ver a mente" no cérebro vivo, fez surgirem novos modos de pensar a superação dos problemas de aprendizagem e de conduta. De acordo com Nikolas Rose e Joelle Abi-Rached (2013), a possibilidade de alterar o funcionamento do cérebro por meio da experiência, de estímulos ambientais ou de medicamentos, tornou o cérebro um território governável. Os efeitos dessas novas tecnologias na produção de verdades sobre o aluno e suas consequências para a educação apenas começam a ser estudados e ainda não podem ser inteiramente previstos. 


\title{
4. O IMPERATIVO DO “DESENVOLVIMENTO” NOS DISCURSOS DA PSICOLOGIA DIRIGIDOS AOS PROFESSORES
}

\begin{abstract}
Parece perverso sugerir que antes do início do século $\mathrm{XX}$ as crianças não se desenvolviam. Evidentemente, seu crescimento da infância à idade adulta sempre foi óbvio para qualquer um com olhos para ver. Ainda assim, não era de maneira nenhuma evidente que um conhecimento sistemático da infância deveria basear-se na noção de que seus atributos devem ser ligados ao longo da dimensão do tempo em uma sequência unificada. Crianças pequenas foram objeto do interesse filosófico nos séculos XVIII e XIX, proporcionando 'experimentos cruciais' que poderiam revelar a presença ou ausência de qualidades e ideias inatas, ou mostrar a extensão em que os atributos humanos derivavam das sensações obtidas pelos órgãos do sentido. Mas no final do século XIX e no início do século XX um novo olhar científico focalizou as crianças pequenas a partir da perspectiva da evolução (ROSE, 1999, p. 144).
\end{abstract}

No decorrer do século XX, a promoção do desenvolvimento humano se tornou quase a própria razão de ser da educação escolar. A observação dos processos da evolução psicológica do aluno, ano a ano, série a série, e a avaliação de cada criança, tornaram-se atribuições fundamentais dos professores. Este capítulo caracteriza os discursos da psicologia sobre o tema, tomando novamente os manuais da disciplina destinados à formação docente como fontes. Mais especificamente, focaliza a presença de variações do enunciado "A ontogênese reproduz a filogênese", afirmação fundamental da chamada "teoria da recapitulação", elaborada pelo médico Ernst Haeckel no campo da embriologia em 1866 e amplamente apropriada no campo das ciências humanas nas décadas seguintes (GOUVÊA; GERKEN, 2010, p. 49).

De acordo com essa teoria, o indivíduo atravessa diversos estágios, que correspondem à forma adulta de seus antepassados na sequência evolutiva. Trazida para o domínio da psicologia, essa formulação serviu como modelo explicativo para diversos aspectos do desenvolvimento, desde a forma e o tamanho do cérebro até a evolução da linguagem e da moral etc. e levou os pesquisadores a aproximarem o comportamento da criança ao do homem primitivo e do deficiente mental. Conforme Stephen Jay Gould, “A recapitulação serviu como teoria geral do determinismo biológico. Todos os grupos 'inferiores' - raças, sexos e classes foram comparados às crianças brancas do sexo masculino" (GOULD, 2003, p. 113). A teoria da recapitulação associou-se às teorias raciais do século XIX que pretenderam explicar as 
desigualdades entre os grupos humanos a partir do critério controverso da raça (GOUVÊA; GERKEN, 2010; SCHWARCZ, 1995).

A análise toma como fontes obras redigidas por autores que lecionaram psicologia na Escola Normal Caetano de Campos e posteriormente na Universidade de São Paulo, bem como na Escola Normal e posteriormente no Instituto de Educação do Rio de Janeiro, entre 1914 e 1972. Orienta-se pelas considerações de Foucault em A arqueologia do saber (2004), em que o autor considera as escolhas teóricas como um modo de entrada em um discurso específico e ponto de partida para a formulação de enunciados. A teoria evolucionista foi empregada nos discursos da psicologia educacional como uma escolha estratégica que, ao permitir a aproximação das ciências naturais, ensejou a formulação de enunciados tidos como verdadeiros sobre o sentido das transformações observadas nas crianças ao longo do tempo. Tornou possível ainda a enunciação das leis do desenvolvimento infantil, a serem obedecidas na educação. Constituiu-se em argumento científico empregado na crítica ao ensino tradicional, fundamentado na chamada "lógica do adulto" e na defesa da sua substituição por um programa adaptado aos interesses e possibilidades de compreensão dos alunos em cada etapa da sua evolução, como se verá adiante. Segundo Foucault,

Uma formação discursiva não ocupa, assim, todo o volume possível que lhe abrem por direito os sistemas de formação de seus objetos, de suas enunciações, de seus conceitos; ela é essencialmente lacunar, em virtude do sistema de formação de suas escolhas estratégicas (FOUCAULT, 2004, p. 74).

Nos discursos da psicologia educacional, nem tudo o que poderia ter sido enunciado sobre as transformações observáveis nas crianças no decorrer do tempo o foi. O recurso à teoria evolucionista fez com que o enunciado "As crianças, assim como os povos primitivos, têm um pensamento mágico, diferente do pensamento racional do adulto civilizado" fosse várias vezes repetido, enquanto esse outro, por exemplo: “A crença em Deus não é inata, mas resultado de um processo de socialização que ocorre em diversas sociedades, tanto tradicionais como modernas e industrializadas", embora possivelmente válido, não tenha sido encontrado. O recurso à teoria evolucionista nos discursos da psicologia educacional afirmou a superioridade das modernas sociedades ocidentais sobre as tradicionais por meio da oposição entre pensamento "mágico" e infantil e pensamento "científico" adulto, mas não foi mobilizada para desqualificar a fé religiosa como menos evoluída do que a confiança na ciência. Essas repetições e lacunas no discurso evidenciam que as escolhas teóricas que se manifestam em uma formação discursiva não estão dissociadas do desejo daqueles que se encontram em posição de enunciá-la. De acordo com Foucault, o desejo, longe de ser um elemento 
perturbador, extrínseco ao discurso, faz parte de seus "elementos formadores" (FOUCAULT, 2004 , p. 75). Se se pretende realizar uma análise do discurso tal como a sugerida por Foucault em $A$ arqueologia do saber, opta-se por descrever as teorias tal como formuladas, em seus próprios termos. Não se busca, para além do que foi pronunciado, uma verdade oculta, deturpada, à espera de ser desvendada:

\begin{abstract}
Não há (ou pelo menos não se pode admitir para a descrição histórica cuja possibilidade aqui traçamos) uma espécie de discurso ideal, ao mesmo tempo último e intemporal, que escolhas de origem extrínseca teriam pervertido, desordenado, reprimido, lançado para um futuro talvez muito longínquo; não se deve supor, por exemplo, que existam sobre a natureza ou sobre a economia, dois discursos superpostos e misturados: um que prossegue lentamente, que acumula suas aquisições e, pouco a pouco, se completa (discurso verdadeiro, mas que só existe em sua pureza nos confins teleológicos da história); o outro, sempre arruinado, sempre recomeçado em contínua ruptura consigo mesmo, composto de fragmentos heterogêneos (discurso de opinião, que a história, ao longo do tempo, lança para o passado) (FOUCAULT, 2004, p. 77).
\end{abstract}

Não se pretende medir a distância que separa os discursos da psicologia educacional pronunciado nos livros selecionados do discurso contemporâneo sobre o desenvolvimento da criança, para explicitar suas ingenuidades, ignorâncias e preconceitos que o afastam do que se admite atualmente como sendo a verdade. Os enunciados foram examinados em seus próprios termos, do modo como se apresentam nos textos analisados, o que quer dizer que não se procurou avaliar o grau de correção e rigor, ou, ao contrário, de simplificação ou distorção desses enunciados em relação à teoria "original" atribuída a Haeckel e posteriormente apropriada por Spencer no campo da sociologia e da psicologia nascentes. Em vez disso, tratouse de mostrá-los tal como se apresentam nas páginas dos livros destinados aos professores.

\title{
3.1 O desenvolvimento humano como objeto para a ciência
}

A preocupação em dividir a vida humana em etapas é anterior ao surgimento da psicologia e foi tema de interesse especializado ao menos desde o Renascimento, quando as crianças se tornaram objeto de atenção especial, passando a ser percebidas como um grupo distinto de pessoas, com necessidades próprias (ARIÈS, 1981). António Ferreira observou que, embora a psicologia do desenvolvimento tenha se estabelecido apenas no decorrer do século XX, a ordenação das fases da vida já ocupava bastante espaço em discursos médicos e pedagógicos nos séculos XVII, XVIII e XIX. Exemplo disso é a obra Didática Magna (1632) 
que propõe uma organização escolar em etapas correspondentes às fases da vida (FERREIRA, 2010, p. 218).

No decorrer do século XIX, o estudo do desenvolvimento humano tomou um novo impulso, quando passou a ser feito no âmbito da biologia, associado à teoria da evolução das espécies. O conceito de evolução tornou-se central nas tentativas de explicar as transformações vividas pelas sociedades desde o homem "primitivo" até o homem dito civilizado das sociedades ocidentais, assim como as mudanças no indivíduo desde a primeira infância até a idade adulta. Também foi empregado para comparar os indivíduos considerados deficientes mentais aos indivíduos tidos como normais. Influenciou ainda a filosofia política, dando origem ao chamado darwinismo social.

Nos estudos sobre o desenvolvimento humano realizados sob a égide da biologia, o conceito de "adaptação" foi fundamental. Compreendia-se que "os processos de desenvolvimento individual seriam definidos por transformações evolutivas desde a precariedade dos mecanismos adaptativos da criança pequena ao ápice das formas de interação com o ambiente característico da idade adulta" (GOUVÊA, GERKEN, 2010, p. 34). Além dos conceitos de "adaptação" e de "evolução", a ideia de raça também foi determinante para esses estudos. As teorias raciais e as teorias embriológicas forneceram os modelos para se pensar sobre os processos de desenvolvimento do indivíduo.

Estava instituída na Biologia do século XIX uma controvérsia a respeito das diferenças entre os povos. A perspectiva monogenista afirmava a igualdade entre as raças e atribuía o grau diferenciado de desenvolvimento entre elas a fatores históricos. Por sua vez, "Os poligenistas, representados principalmente por Taine, Gobineau e Renan, afirmavam que os homens tinham origens distintas, tendo partido de diferentes centros de criação, os quais teriam originado humanidades plurais e cindidas" (op. cit., p. 40). Com a publicação de $A$ origem das espécies, acabou prevalecendo a perspectiva monogenista, mas que, na prática, equivalia ao poligenismo, ao considerar as diferenças entre as raças muito antigas e, portanto, irreversíveis. Para esse resultado, concorreu a publicação da obra Desigualdade das raças humanas (1856), de Gobineau, que alcançou grande divulgação à época e teve ampla aceitação no meio científico (SCHWARCZ, 1995; GOUVÊA, GERKEN, 2010).

Os estudos biológicos da embriologia também influenciaram os estudos sobre o desenvolvimento do indivíduo ao estabelecerem uma analogia entre os processos evolutivos 
intrauterinos e os posteriores, do nascimento à idade adulta. Ernst Haeckel (1834-1919) formulou a lei biogenética ou teoria da recapitulação já mencionada:

\begin{abstract}
A perspectiva monista de Haeckel, que estabelecia uma "homologia entre os processos evolutivos naturais, psíquicos e sociais" era também poligenista, ao afirmar que embora houvesse um único gênero humano, esse englobava espécies distintas e hierarquicamente ordenadas. No que dizia respeito ao desenvolvimento psicológico, comparava-se os traços intelectuais e emocionais do selvagem, do primitivo, às características da criança branca. Para a nascente psicogenia, "as possibilidades do desenvolvimento individual estariam definidas por seu pertencimento sociorracial" (GOUVÊA, GERKEN, 2010, p. 56).
\end{abstract}

Herbert Spencer (1820-1930) foi o principal divulgador da concepção segundo a qual todos os fenômenos físicos, sociais e naturais se processam de acordo com um modelo evolutivo universal. Acreditava que havia "uma homologia nos processos de desenvolvimento individual e social em que as crianças manifestariam os mesmos traços caracterológicos, psíquicos e morais das raças ditas primitivas" (GOUVÊA; GERKEN, 2010, p. 63). Adepto de uma perspectiva lamarkiana, rejeitou a lei universal do progresso, substituindo-a pela hipótese segundo a qual os processos de adaptação dos grupos humanos podiam orientar-se tanto para o progresso quanto para a degeneração. Spencer "inverteu a perspectiva de determinação biológica tradicional, entendendo que o tamanho do cérebro seria função do desenvolvimento social. Para ele, a evolução social não seria função da evolução biológica, mas sua determinante" (GOUVÊA; GERKEN, 2010, p. 67).

A partir de 1870, realizaram-se estudos monográficos sobre o desenvolvimento a partir da observação de crianças, frequentemente os próprios filhos dos pesquisadores. Esses estudos resultavam em diários, cada vez mais comuns no final do século XIX, cuja elaboração era motivada pela expectativa de que a observação do desenvolvimento da criança permitiria compreender a evolução da humanidade, bem como as características que distinguem os humanos dos animais e ainda identificar até que ponto o comportamento era herdado ou aprendido (ROSE, 1999).

Nesse conjunto, destacou-se o trabalho Tieldmanns Record of infant life, escrito por um professor alemão de filosofia, interessado em investigar o surgimento da inteligência na criança a partir da observação de seu filho. Darwin também se dedicou ao registro sistemático das ações de seu primeiro filho, nascido em 1839. Em 1881, Wiliam Preyer publicou The Mind of the Child: observations concerning the mental development of the human being in the first year, considerado o trabalho inaugural da ciência psicogenética. Preyer era fisiologista e colega de Haeckel na Universidade de Jena, cujo trabalho conhecia. Interessava-se também pelo 
estudo do desenvolvimento embrionário mas, “Ao contrário de Taine e Darwin, Preyer recusava o estudo comparativo com outras espécies, por considerá-lo inútil para a compreensão dos processos de desenvolvimento humanos" (GOUVÊA; GERKEN, 2010, p. 85).

Cumpre destacar ainda o trabalho de James Baldwin (1861-1934), psicólogo norteamericano considerado precursor de Piaget. Formado em Filosofia em 1884, ganhou uma bolsa de estudos para estudar com o eminente psicólogo William Wundt. Seguindo a tradição dos estudos monográficos a partir da observação de crianças, realizou registros sobre o desenvolvimento de suas duas filhas. Seu interesse pela origem das funções psíquicas afastouo da perspectiva estrutural de Wundt e da psicologia experimental e aproximou-o da psicologia funcional de William James (1842-1910), que privilegiava a adaptação do organismo ao meio. Baldwin formulou dois princípios fundamentais para os estudos dos processos genéticos: “Todas as séries verdadeiramente genéticas são irreversíveis e cada novo estágio, ou termo, nas séries verdadeiramente genéticas, são sui generis, um novo modo de presença naquilo que é chamado realidade" (GOUVÊA; GERKEN, 2010, p. 112). Considerou que o desenvolvimento da mente pode ser visto de qualquer um desses três pontos principais: A perspectiva filogenética (estabelecimento de relações entre o desenvolvimento humano e o de outras espécies); A perspectiva antropológica (comparação entre diferentes grupos sociais, do homem primitivo ao civilizado); a perspectiva psicogenética (estudo do desenvolvimento psicológico do indivíduo 'normal'). No diálogo entre a Biologia, a Antropologia e a Psicologia, procurou formular as bases para uma ciência psicogenética (GOUVÊA; GERKEN, 2010; FERREIRA, 2010).

Esses primeiros estudos de crianças foram importantes no início para a psicologia do desenvolvimento, mas foram principalmente as investigações realizadas em clínicas e escolas que permitiram a ampliação dos seus conhecimentos. As instituições de saúde e educação infantil forneceram aos especialistas ambiente mais propício à observação, ao reunirem no mesmo espaço uma grande quantidade de crianças de diversas faixas etárias. Nas escolas criaram-se condições ótimas para a observação dos comportamentos, a realização de comparações e o estudo das diferenças individuais. Os psicólogos passaram a identificar padrões de comportamento para cada idade, alinhados num eixo temporal dividido em etapas. Esse modo de sistematização das observações tornou possível a comparação entre as capacidades de qualquer indivíduo e a norma para a sua faixa etária. Diversas manifestações relativas à postura, locomoção, aquisição de vocabulário, destreza manual, modos de interação com os objetos e com outras pessoas, interesse sexual etc. passaram a ser apreciadas como indícios de desenvolvimento normal, adiantado ou atrasado. As escalas de desenvolvimento 
multiplicaram-se e tornaram-se parte do saber considerado imprescindível para os professores. Por meio de sua divulgação, mães, pediatras, professores e outros profissionais encarregados dos cuidados e da educação das crianças e adolescentes foram convocados a atuar como vigilantes do desenvolvimento, sempre atentos às manifestações atípicas do comportamento que pudessem sugerir a necessidade de intervenções especializadas (ROSE, 1999).

Em solo brasileiro, a psicologia do desenvolvimento difundiu-se a partir da perspectiva funcionalista, especialmente por meio da divulgação das obras de William James, Édouard Claparède e John Dewey, recorrentes na bibliografia dos manuais. (CAMPOS et al, 2004a). Em estudo histórico sobre a importação das ideias estrangeiras das perspectivas genética e funcional na produção da psicologia brasileira do século XX, Regina Helena de Freitas Campos e colaboradores propuseram uma divisão do período em cinco fases. A primeira vai até 1930 e coincide com a fase heroica da Psicologia brasileira, na designação de Lourenço Filho, caracterizada pela iniciativa de um pequeno grupo de educadores interessados em divulgar a produção estrangeira no país. Nesse período estabeleceram-se duas tendências da psicologia funcional no Brasil:

\begin{abstract}
a primeira delas, iniciada por Manuel Bomfim, dialoga sobretudo com a tradição europeia, especialmente nas vertentes desenvolvidas por Alfred Binet, no Laboratório de Psicologia Experimental da Sorbonne, em Paris, e por Édouard Claparède, na Suíça; A segunda presente na obra de Medeiros e Albuquerque, Sampaio Dória e Anísio Teixeira, sofre uma maior influência da perspectiva funcionalista norteamericana, especialmente daquela desenvolvida nas obras de William James e John Dewey. O próprio Lourenço Filho faz parte desse pequeno grupo de estudiosos que iniciaram o trabalho em Psicologia no Brasil na perspectiva funcionalista, e sua obra caracteriza-se pelo amplo conhecimento tanto da vertente europeia quanto da norteamericana (CAMPOS et al., 2004a, p. 162).
\end{abstract}

Nas décadas de 1930 e 1940, segunda fase, buscou-se aproximar a psicologia da realidade brasileira, por meio de investigações conduzidas no país. Surgiram então os serviços de psicologia associados ao sistema escolar, que criaram a oportunidade para a realização de estudos sobre os escolares brasileiros, de que são exemplos o Laboratório de Psicologia da Escola de Aperfeiçoamento de Professores de Minas Gerais, criado por Léon Walther em 1928 e posteriormente dirigido por Helena Antipoff; o Serviço de Psicologia Aplicada anexo à Diretoria Geral do Ensino de São Paulo, organizado em 1931, a cargo de Noemy da Silveira Rudolfer e a Seção de Ortofrenia e Higiene Mental do Instituto de Pesquisas Educacionais do Rio de Janeiro, criada em 1934 e dirigida por Arthur Ramos. Na fase seguinte, de 1940 a 1960 , expandiu-se a pesquisa em psicologia no Brasil, com ênfase nos estudos sobre os efeitos da cultura na formação da personalidade, de que são exemplos os trabalhos realizados por Anitta 
Cabral na Faculdade de Filosofia da Universidade de São Paulo, e o canadense Otto Klineberg, que atuou como professor de psicologia visitante na instituição. Na Faculdade de Filosofia da Universidade Federal do Rio de Janeiro, difundiu-se a partir desse período a teoria de Piaget, por iniciativa de Antônio Gomes Penna. Na quarta fase, que se estende de 1960 a 1990, foram criados os cursos superiores de psicologia no Brasil e posteriormente os cursos de pósgraduação associados à formação de novos grupos de pesquisa, muitos dos quais dedicados aos estudos piagetianos e suas implicações para a educação (CAMPOS et al., 2004b, p. 196). Essa fase se caracterizou pela intensificação do debate em torno das relações entre cultura e desenvolvimento psicológico e pela centralidade do fracasso escolar como tema de investigação, fosse a partir da teoria da carência cultural ou outras perspectivas, que se empenharam em fazer a sua crítica, como foi o caso dos trabalhos realizados a partir do materialismo histórico. Na última fase, iniciada em 1990, a perspectiva genético-funcional, especialmente referida às obras de Piaget e Vygotsky, ampliou-se a partir da criação e expansão dos grupos de pesquisa e programas de pós-graduação em psicologia.

\subsection{A teoria evolucionista ensinada aos professores em São Paulo e no Rio de Janeiro}

Em São Paulo, o período inicial do ensino de psicologia aos normalistas pode ser melhor compreendido no âmbito da reforma do ensino empreendida por Caetano de Campos em 1890, emblemática da nova ordem republicana. Para o reformador, o novo regime político, ao entregar ao povo a direção de si mesmo, requeria a instrução para formar suas escolhas e convicções em bases científicas. Com esse propósito construiu-se na Praça da República o edifício majestoso da nova Escola Normal e a Escola Modelo anexa, onde os normalistas deveriam aprender na prática o moderno método intuitivo, adequado à psicologia infantil. Para

implantá-lo apropriadamente, contrataram-se professoras formadas nos Estados Unidos e importaram-se materiais didáticos (CARVALHO, 1989).

A psicologia já estava prevista no currículo da instituição desde 1892, no âmbito da disciplina Psicologia, Moral e Educação Cívica, a qual, no entanto, foi suprimida antes mesmo de chegar a ser ministrada. Mais tarde, na reforma curricular realizada pelo novo diretor Oscar Thompson, em 1911, a psicologia foi restituída, na disciplina Psicologia, Pedagogia e Educação Cívica e tornou-se símbolo da modernização do ensino, capaz de proporcionar bases científicas às práticas escolares. Em 1914 foi criou-se na Escola Normal de São Paulo o 
Gabinete de Antropologia Pedagógica e Psicologia Experimental, com o objetivo de favorecer a realização de investigações sobre os alunos que permitissem formar classes homogêneas e ajustar o ensino às diferenças individuais (TAVARES, 1995; CARVALHO, 1997). De 1920 em diante, por iniciativa de Sampaio Dória, a matéria que ele próprio lecionava desde 1914 foi desmembrada e a psicologia se tornou uma matéria independente (TAVARES, 1995; MONARCHA, 1999).

Em 1931, a Escola Normal Caetano de Campos foi transformada em Instituto Pedagógico e dois anos mais tarde em Instituto de Educação de formação em nível superior. Esse foi incorporado à Faculdade de Filosofia, Ciências e Letras (FFCL) em 1934, quando foi fundada a Universidade de São Paulo. Em 1938, o Governo do Estado extinguiu o instituto e criou uma Seção de Educação na FFCL - USP, posteriormente designada como Seção de Pedagogia, para a qual se transferiram os professores do antigo instituto. Essa transição, que impôs a coexistência dos professores da Faculdade de Filosofia com os novos professores, antigos normalistas, não foi bem aceita pelos primeiros, que viam com despeito e desconfiança os docentes da Seção de Educação. Criou-se um espaço universitário cindido, em que o curso de Didática e seus professores eram desprestigiados. Em 1946, André Dreyfus, diretor da Faculdade, solicitou ao ministro da educação uma mudança no currículo, que resultou em decreto que autorizou a redução da parte pedagógica da formação dos professores secundários às disciplinas de Psicologia Educacional, Didática Geral e Didática Especial (BONTEMPI, 2011). Essa providência evidenciava a desvalorização da formação pedagógica, mas também o reconhecimento da importância do estudo da psicologia pelos futuros professores.

Na década seguinte, criou-se na FFCL-USP o curso de Psicologia, iniciado em 1958 e formado pela reunião da Cadeira de Psicologia Educacional, do curso de Pedagogia e da Cadeira de Psicologia do curso de Filosofia, a qual se desdobrou em outras duas: Psicologia Clínica e Psicologia Experimental e Social. A partir de 1968, com a Reforma Universitária e a elaboração dos novos Estatutos da Universidade de São Paulo, foi criada a Faculdade de Educação, que passou a funcionar em janeiro de 1970, no mesmo ano em que foi instalado na USP o Instituto de Psicologia, criado pelo decreto n. 52.326 do Governador do Estado, de 1969. Desde então, o ensino e a pesquisa em psicologia voltado às questões relativas à educação tiveram continuidade tanto na Faculdade de Educação quanto no Instituto de Psicologia ${ }^{11}$.

\footnotetext{
${ }^{11}$ Informações disponíveis nos sites do Instituto de Psicologia e da Faculdade de Educação da Universidade de São Paulo: http://www4.fe.usp.br/ e http://www.ip.usp.br/site/
} 
Sampaio Dória (1883-1964) e Lourenço Filho (1897-1970) eram formados em Direito e sucederam-se no ensino de psicologia para os alunos da Escola Normal Caetano de Campos, além de terem desempenhado funções importantes na administração do ensino e na política do país. Sampaio Dória participou na criação da Liga Nacionalista de São Paulo e, em 1920, tornou-se Diretor Geral da Instrução Pública do Estado de São Paulo. Lecionou na Faculdade de Direito de São Paulo, tendo sido exonerado do cargo por Getúlio Vargas. Com o fim do Estado Novo, foi nomeado Ministro da Justiça (BOTO, 2018, p. 54). Em seu concurso de ingresso na Escola Normal Caetano de Campos Sampaio Dória apresentou a tese Princípios de pedagogia (1914), de que se tratará adiante. Lourenço Filho foi seu aluno e dedicou-lhe sua Introdução ao Estudo da Escola Nova (1930). Educador atuante, foi Diretor Geral da Instrução Pública no Ceará e em São Paulo, diretor do Instituto de Educação do Distrito Federal e presidente da Associação Brasileira de Educação, dentre outras posições de destaque no campo educacional. Atuou também na divulgação do conhecimento especializado da psicologia, tendo traduzido Psicologia Experimental, de Henri Piéron; A Escola e a Psicologia Experimental, de Édouard Claparède e Testes para a Medida da Inteligência, de Binet e Simon, e dirigido a Biblioteca de Educação da Companhia Melhoramentos de São Paulo (CATANI, 2018, p, 102103). Na Escola Normal, Lourenço Filho foi sucedido por Noemy da Silveira Rudolfer (19021988), que havia sido sua aluna na Escola Normal Padre Anchieta. Na ocasião de seu ingresso na USP, ela apresentou a tese A evolução da Psicologia Educacional através de um histórico da Psicologia moderna (1936), posteriormente publicada na forma de livro, com o título de Introdução à Psicologia Educacional, dedicada a Lourenço Filho. Os três professores da Escola Normal paulista foram signatários do Manifesto dos Pioneiros da Educação Nova, de 1932.

Onofre de Arruda Penteado Junior trabalhou ao lado de Noemy Rudolfer como catedrático de Didática Geral e Especial na seção de Pedagogia da FFCL-USP. Escreveu o Compêndio de Psicologia: problemas de psicologia educacional para o uso das escolas normais (1949). Dante Moreira Leite, autor de $O$ desenvolvimento da criança, publicado pela primeira vez em 1971, cursou Filosofia na mesma instituição. Sob a orientação de Annita Cabral, tornouse doutor e posteriormente professor livre-docente em psicologia educacional no recém-criado Instituto de Psicologia da USP.

Em sua história da psicologia educacional, Noemy Rudolfer considerava que 
(...) dois grandes fatos emprestam ao século XIX especial significação para a psicologia educacional: o nascimento da psicologia experimental e o advento da teoria evolucionista. Os dois pontos de vista resultantes, o experimental e o genético, proporcionam novo estímulo e nova direção às cogitações da psicologia. E, conquanto o laboratório devesse, numa certa extensão, substituir o estudo pela investigação em alguns problemas, por outro lado cresciam de vulto as considerações relativas ao desenvolvimento da consciência e do comportamento devido ao fato de estar, o homem, em relação íntima com os seus semelhantes e com os outros animais. Além disso, a teoria evolucionista contribuiu com suas concepções capitais para a mudança da psicologia geral e para a organização definitiva da psicologia educacional: a da herança mental que nos é legada e a da adaptação do indivíduo ao meio (RUDOLFER, 1936, p. 135).

$\mathrm{O}$ recurso à teoria evolucionista favoreceu a legitimação científica da psicologia educacional, ao aproximá-la das ciências naturais. A partir do seu estudo, esperava-se desvendar as leis do desenvolvimento. A psicologia educacional tomava como ponto de partida o enunciado segundo o qual "a criança não é um homem em ponto pequeno, tem sua psicologia própria” (DÓRIA, 1914, p.11), a qual precisava ser levada em consideração pelos adultos encarregados de ensiná-la. Associava-se a essa ideia a afirmação de que "a criança é o pai do homem" (LEITE, 1971/2010, p. 41-42), considerando-se que o comportamento do adulto se explicava pela história da sua criação, de modo que as consequências dos erros cometidos na educação da criança se fariam sentir por toda a vida. Essas afirmativas eram associadas à hipótese da recapitulação na recomendação de Herbert Spencer de "que a educação seja em ponto pequeno uma reprodução da cultura humana" (apud DÓRIA, 1914, p. 18).

Os livros de Sampaio Dória, Lourenço Filho, Noemy Rudolfer e Onofre Penteado Junior endossavam a ideia principal da recapitulação, de que a criança se aproximava do homem primitivo por seu comportamento e modo de pensar. Parte expressiva de Princípios de pedagogia é dedicada à exposição desse princípio e suas implicações educacionais. Conforme Sampaio Dória, o desenvolvimento humano era determinado por dois conjuntos de fatores, os de ordem social e os de ordem individual. Os de ordem social eram explicados pela teoria da recapitulação: "Na opinião quase unânime dos pedagogistas, dignos desse nome, a criança se desenvolve como se desenvolveu a espécie." (DÓRIA, 1914, p. 13, destaque do autor). Referiase a Comte para estabelecer o paralelismo entre a história da civilização e a educação da criança. Em sua aplicação pedagógica, suprimia-se a idade metafísica da humanidade e os anos de formação eram divididos em duas fases: a fase da educação "espontânea ou materna", que reproduzia "a fase feitícica (sic) da cultura" e a educação pública, que tornaria "os indivíduos capazes das sociedades superiores, unificadas no gênero humano" (DÓRIA, 1914, P. 14-15). Para Spencer, o governo das crianças devia seguir a história política: 
Por fim, uma passagem última, onde a lei da recapitulação abreviada s’impõe ao espírito de Spencer: 'Que a história da legislação doméstica seja um resumo da história da legislação política: a princípio, a autoridade despótica, quando essa autoridade for de fato necessária; logo depois um constitucionalismo nascente, em que a liberdade do indivíduo é reconhecida nalguns pontos; e, afinal, aumentos sucessivos da liberdade do vassalo até a completa abdicação do senhor' (apud DÓRIA, 1914, p. 19).

Em Introdução ao Estudo da Escola Nova (1930), Lourenço Filho considerava que os estudos sobre a infância haviam alcançado o limiar da cientificidade graças à teoria evolucionista. Desde então a criança já não era comparada ao adulto civilizado, mas compreendida a partir da aproximação entre o seu comportamento e o dos animais, povos primitivos e alienados. Seguindo Sampaio Dória, Lourenço Filho afirmava que a perspectiva evolutiva fornecera o modelo para a compreensão das bases sociais do comportamento humano:

\begin{abstract}
Ao mesmo passo, a psicologia dos primitivos vinha demonstrar a importância da interpsicologia, ou da influência do meio social na formação do comportamento humano. O pensamento não seria mais produto individual, mas necessidade social, fabricada pela sociedade. Uma velha ideia de Comte, renovada por Durkheim e Tarde. E, desde então, as reações verbais, ou seja, a linguagem (como outros produtos sociais: arte, religião, direito) passaram a ser objetivamente estudados na criança e no selvagem, da mesma forma por que, neles, se estudavam antes as reações simplesmente motrizes. Estavam assentados os primeiros fundamentos da psicologia realmente científica (LOURENÇO FILHO, 1930, p. 46-47).
\end{abstract}

Noemy da Silveira Rudolfer, em sua Introdução à psicologia educacional, dedicava um capítulo à "Psicologia da criança e suas contribuições à psicologia educacional", em que dividia os estudos sobre o desenvolvimento infantil em três fases: período filosófico, período pré-científico e período científico. Eram representantes do primeiro período Rousseau, Pestalozzi e Froebel que, embora já manifestassem interesse pela criança e defendessem a adaptação da educação às suas características e necessidades, pretendiam conhecer a criança através "de experiências ocasionais, de apriorismos e inferências filosóficas" (RUDOLFER, 1961, p. 136). O segundo período, pré-científico, era apresentado como aquele em que começaram a ser produzidos relatos baseados na observação de crianças na forma de diários, porém sem a preocupação de coletar informações sobre um grande número de indivíduos ou controlar as condições de observação. A autora referia-se a Darwin, que escreveu Biographical Sketch of an Infant ${ }^{12}$, como o principal representante dessa fase. Mencionava também Preyer,

\footnotetext{
12 DARWIN, Charles. A Biographical Sketch of an Infant. Primeira publicação em Mind, n.2, p. 285-294, 1877. Disponível em: http://psychclassics.yorku.ca/Darwin/infant.htm Acesso em setembro 2019.
} 
autor de The Mind of the Child ${ }^{13}$, como precursor do período seguinte, que realizara observações sistemáticas de uma criança nos seus primeiros três anos de vida. Afirmava que a psicologia da criança alcançara o status de conhecimento científico com Stanley Hall que, em lugar de basear-se apenas em registros de observação do comportamento infantil, empregou questionários em suas investigações:

\begin{abstract}
Nos primeiros dias do darwinismo, Haeckel mostrara que o embrião humano passa por estádios que se assemelham àqueles pelos quais a raça passou; formula, assim, em 1866, a lei biogenética - a embriogênese repete a filogênese (p. 114) (...) Sobre esses fundamentos, Hall expõe no seguinte princípio essa herança: a criança passa por uma série de estádios semelhantes aos da vida da espécie. Passa, como a espécie, por um período de caça, de construção, de coleção, de pastoreio. Igualmente, interpreta os jogos da criança como sendo o exercício daquelas atividades próprias do estádio cultural a que corresponde seu próprio estádio. A educação, portanto, deve, no seu entender, consistir em oferecer-se à criança as oportunidades para expansão desses impulsos característicos de cada época de desenvolvimento, com o seu ciclo inevitável de instintos e interesses. Foi da psicologia comparativa que ele tirou a noção da evolução dos instintos, assim como colheu, da biologia, a teoria da recapitulação (RUDOLFER, 1961, p. 114-115).
\end{abstract}

Apesar disso, considerava criticáveis os seus procedimentos, pois entendia que o psicólogo "empregou métodos quantitativos rudes" ao interpretar os dados dos seus questionários, cuja construção, além disso, afastava-se da "técnica moderna" (RUDOLFER, 1961, p. 137). Depois de apresentar o pioneirismo de Stanley Hall, a autora referia-se aos seus seguidores Terman, Gesell, Goddard, Sully e Baldwin. Esse último era autor da obra Mental Development in the Child and the Race ${ }^{14}$, que abrira "o caminho para o estudo da correlação entre os dados da psicologia da criança e os da biologia”. Noemy Rudolfer afirmava que "Coube a Baldwin ver o inverso da ideia do desenvolvimento racial, aplicando o plano do desenvolvimento racial ao estudo da mente individual", sem se deter, contudo, na explicação da teoria do autor (1961, p. 145). Ao final do capítulo intitulado "A psicologia da criança e suas contribuições à psicologia educacional", a autora informava que a teoria da recapitulação já não era aceita para explicar a evolução dos instintos e interesses na criança. Dizia: "A moderna psicologia educacional não crê, porém, que a evolução das tendências instintivas obedeça à filogênese: o papel do meio é preponderante na determinação do objeto sobre o qual se exercerão os instintos e interesses” (RUDOLFER, 1961, p. 153).

\footnotetext{
${ }^{13}$ PREYER, William. The mind of the Child: observations concerning the mental development of the human being in the first year. New York: Appleton, 1881.

${ }^{14}$ BALDWIN, James Mark. Mental Development in Child and Race. Edição inicial 1895. Disponível em http://psyclassics.yorku.ca/Baldwin.htm Acesso em setembro 2019.
} 
No Compêndio de psicologia (1949), de Onofre de Arruda Penteado Junior, não há um capítulo especialmente dedicado ao tema do desenvolvimento da criança, mas a teoria da recapitulação está presente em várias passagens do livro, cujas referências fundamentais são as obras de Piaget e Claparède. Em todos os casos buscava-se evidenciar as semelhanças entre a criança e o "homem primitivo". É significativo que esse "homem primitivo" era abstraído de qualquer contexto, não se referia a qualquer comunidade em particular. No máximo era o aborígene ou o índio de certa tribo não especificada:

A criança, segundo a explicação de Piaget, 'sobredetermina' suas ideias. Em vez de as definir de maneira unívoca, as define por muitos caracteres ao mesmo tempo. Assim, vivente, para ela é o que está em movimento, o que se move. Generaliza por confusão, mistura os gêneros, aproveita as analogias acidentais, as aproximações fortuitas. O mesmo fenômeno se verifica nos primitivos: as árvores, os rochedos podem possuir sentimentos humanos. (PENTEADO JUNIOR, 1949, p. 126).

No livro O desenvolvimento da criança (1971) de Dante Moreira Leite, a teoria da recapitulação já não aparece como modelo para a compreensão do desenvolvimento, sendo referida como teoria ultrapassada, pertencente ao passado da psicologia:

\begin{abstract}
O paralelismo entre a ontogênese e a filogênese - isto é, o paralelismo entre o desenvolvimento do indivíduo e o da espécie - foi princípio aceito praticamente sem discussão. Em alguns autores do século XIX e mesmo do século XX, levou à ideia de que haveria raças 'infantis', onde seria possível encontrar o desenvolvimento da criança, mas não do adulto; em outros casos, esperava-se que a criança manifestasse as várias fases de evolução da humanidade. Hoje, dificilmente se aceitaria esse princípio, pois não é fácil dizer o que é infantil no comportamento, a não ser que se tenha um critério social de definição. Como se observa no texto de Baldus (capítulo 3), a criança no grupo primitivo pode parecer mais adulta do que nos povos industrializados; além disso, mesmo o adulto não perde o gosto pelo jogo e pelo brinquedo, supostamente infantis (LEITE, 1971/2010, p. 119).
\end{abstract}

Nos compêndios examinados anteriores a 1971, a teoria da recapitulação como lei do desenvolvimento associava-se à constatação do problema da inadequação dos programas de ensino. Segundo os autores, na escola tradicional, os programas eram elaborados segundo a lógica dos adultos e não respeitavam o desenvolvimento das crianças. Assim como para Spencer o governo das crianças devia reproduzir a história política, de acordo com Sampaio Dória a educação deveria reproduzir a história da humanidade. Noemy Rudolfer ensinava que, de acordo com Stanley Hall os professores deveriam transformar-se em investigadores dos interesses típicos de cada fase do desenvolvimento. A Escola Nova, que levava em conta o conhecimento da psicologia da infância aparecia como solução pedagógica progressista: 
Em virtude dessa concepção, o educador se torna um investigador desses instintos e interesses para a eles adaptar o programa e a organização escolar. Assim, diz ele que, dos oito ou nove anos à puberdade, há diminuição do grau de crescimento, de modo a haver um relativo repouso do corpo, aumentando a vitalidade, a atividade e o poder de resistir às moléstias. É um período que corresponde ao período humano acima do símio e antes da era histórica, quando os nossos ancestrais já estavam bem ajustados ao seu ambiente. Não é época propícia para acentuar o raciocínio, o pensamento criador, apelar para o julgamento ou a originalidade. Mas é a ocasião para o exercício, formação de hábitos e mecanismos. É então que o professor deve lançar os fundamentos da educação pela leitura, escrita e aritmética (RUDOLFER, 1936, p. 115)

Entre São Paulo e Rio de Janeiro verifica-se uma correspondência quanto à sucessão dos professores de psicologia na Escola Normal e Instituto de Educação. Como foi dito, em São Paulo, os primeiros professores de psicologia foram Sampaio Dória e Lourenço Filho, que exerceram o cargo de Diretor Geral da Instrução Pública e outras posições de destaque na política educacional. Depois deles, a disciplina foi ensinada por Noemy Rudolfer, professora normalista. No Rio de Janeiro, os pioneiros foram Manoel Bomfim, que exerceu também a função de Diretor da Instrução Pública, Plínio Olinto e Maurício de Medeiros. No Rio, a disciplina ficou posteriormente sob o encargo de Iva Waisberg Bonow, formada em 1934 no mesmo Instituto de Educação onde veio a lecionar. A trajetória dos docentes nessas instituições evidencia uma tendência mais geral do ensino da psicologia para professores em formação no Brasil, o qual foi inicialmente realizado nas escolas normais por advogados e médicos que exerceram cargos importantes na administração do ensino e posteriormente por professoras formadas nas próprias Escolas Normais e Institutos de Educação.

Manuel Bomfim, Plínio Olinto e Maurício de Medeiros estudaram na Faculdade de Medicina do Rio de Janeiro e lecionaram na Escola Normal. Bomfim viajou a Paris em 1902 para estudar psicologia. Foi discípulo de Alfred Binet, que o ajudou a planejar a instalação do primeiro laboratório de psicologia aplicada do país, ocorrida em 1906, no Pedagogium. Exerceu também os cargos de diretor da Escola Normal e Diretor da Instrução Pública do Rio de Janeiro. É autor dos livros Lições de pedagogia (1915) e Noções de psicologia (1ª .ed.1916), entre outros. Pelo conjunto de sua obra, Bomfim é atualmente considerado um autor cujas ideias foram contra-hegemônicas, uma vez que ele se opôs às teorias raciais difundidas no Brasil nas primeiras décadas do século XX e explicou as condições sociais vividas no país em função da exploração colonial. Pesquisadores dedicados ao estudo de suas produções constataram que já nas primeiras décadas do século XX o autor fez a crítica da psicologia experimental que se restringia aos dados coletados em laboratório para explicar a "vida do espírito" (ANTUNES \& RONCA, 2018; CAMPOS, 2004a). 
Em Noções de psicologia, o autor afirmava que "A formação da personalidade se realiza como resultante das tendências herdadas e da influência do meio" (BOMFIM, 1917, p. 302). A perspectiva evolucionista está presente de uma maneira em que se equilibram as forças da natureza e da sociedade na determinação do desenvolvimento. Ao descrever a condição inicial da criança, o autor contestava o enunciado segundo o qual a mentalidade da criança a aproxima dos animais e dos adultos anormais. Dizia:

\begin{abstract}
De fato, ainda não existe, na criança de tenra idade, unidade subjetiva; mas deve haver uma consciência fragmentada - repercussão de excitações de origem interna e dos sentidos, influxos de tendências suscitadas, de apetites despertados, esboços de emoções, correspondendo à atividade de centros inferiores, sub-corticais, ainda não contidos pela atividade organizada do córtex. Disto resulta que a consciência da criança não tem análogo, nem nos estados anormais do adulto, nem na série animal (BOMFIM, 1917, p. 303).
\end{abstract}

Contudo, poucas páginas adiante, validava o enunciado central da teoria da recapitulação, ao afirmar que "cada indivíduo refaz abreviadamente a marcha geral da evolução da espécie” (BOMFIM, 1917, p. 309) e comparava o egoísmo da criança ao do homem primitivo, explicando-o como "deficiência mental”, nos seguintes termos:

\footnotetext{
Nos primeiros tempos de vida consciente e inteligente, a criança tudo refere a si mesma, e, realmente, só sente os próprios interesses. Dizemos, então, que ela é egoísta. Sim; é egoísta, não por defeito moral, essencial, mas por deficiência mental - por não compreender os interesses dos outros; falta-lhe o elemento representativo para despertar os instintos sociais e morais. Esses instintos, mais modernos que os propriamente egoístas, só mais tarde se revelam. A criança é egoísta por ser egocêntrica; o homem primitivo é também egocêntrico, por insuficiência mental (BOMFIM, 1917, p. 311).
}

Bomfim recorria ao psicólogo norte-americano James Baldwin (1861-1934) para explicar o desenvolvimento infantil e afirmava que "O desenvolvimento psíquico é uma verdadeira formação evolutiva, relativamente rápida, e onde não se encontram, nos momentos que se sucedem dois perfeitamente iguais, nem absolutamente diversos" (BOMFIM, 1917, p. 316-317). Destacava dois períodos cruciais do desenvolvimento, o primeiro dos quais correspondia ao momento em que a criança "com seu aparelho cerebral completo, começa a conhecer, e acode, com os poucos elementos fonéticos que possui, a indicar e a nomear os seres que vai distinguindo em conhecimentos diretos" (BOMFIM, 1917, p. 317). No segundo período crítico, a criança tomava consciência da insuficiência de sua compreensão e de seus conhecimentos, passava a requisitar as explicações e os conhecimentos dos adultos e começava assim a "empregar a experiência acumulada da espécie” (BOMFIM, 1917, p. 317). 
Seu colega e sucessor na Escola Normal do Rio de Janeiro, Plínio Olinto era psiquiatra e atuara no Laboratório do Hospital Nacional de Psicopatas do Rio de Janeiro antes de ingressar, em 1916, na Escola Normal onde lecionou psicologia até 1930. Seu manual da disciplina foi dedicado a Bomfim e a Juliano Moreira, ele também médico formado na Faculdade de Medicina da Bahia e precursor da psicanálise no Brasil.

Tal como Bomfim, Plínio Olinto afirmava que as influências do meio cósmico, social e do ensino intencional eram os três fatores determinantes do desenvolvimento infantil. No seu texto, a perspectiva do evolucionismo aparece em enunciados como: "Indiscutivelmente é o homem o animal que maior e melhor capacidade de adaptação ao meio revela como manifestação de sua inteligência" (OLINTO, s.d., p. 37) e "cada um repete, nos limites de suas possibilidades, o esforço que empregou a humanidade na sua socialização, pois é sabido que o indivíduo refaz, abreviadamente, a marcha geral da evolução da espécie" (OLINTO, S.D., p. 254). Comparece ainda na aproximação entre o comportamento da criança e do animal:

O animal e a criança traduzem seu comportamento através dos instintos. No homem adulto a conduta, modificada pela experiência vae-se tornando inteligente. Os puros instintos são substituídos por instintos modificados, as tendências instintivas intervêm, os instintos adaptativos tomam o lugar dos primeiros (OLINTO, s.d., p. 41).

Maurício de Medeiros também era médico formado pela Faculdade de Medicina do Rio de Janeiro, com especialização na Europa, sob orientação de George Dumas, assim como Manoel Bomfim. Em 1907 defendeu sua tese de doutorado, Os métodos da Psicologia. Atuou no Pedagogium e tornou-se professor de psicologia na Escola Normal. É de sua autoria o livro Aspectos da Psicologia Infantil (1952). O livro não apresenta a estrutura de manual de ensino, reúne textos independentes, dentre os quais "Neuroses e psicoses do climatério feminino" e "Psiquiatria e Direito". A teoria da recapitulação é apresentada no segundo capítulo, "O mundo imaginário das crianças", nos seguintes termos:

Há uma lei em biologia que sintetiza o resultado de longas observações. Segundo essa lei, a evolução do indivíduo reproduz abreviadamente a evolução da espécie. Em termos mais bombásticos, porque científicos, se diz: “a ontogênese reproduz a filogênese" (MEDEIROS, 1952, p. 39).

O autor explicava o sentido da recapitulação no desenvolvimento físico do período embrionário e depois no desenvolvimento psicológico, quando afirmava que "A espécie humana recapitula no indivíduo o lento progresso da espécie" e ainda que "A observação dos povos primitivos neles assinala uma tendência ao raciocínio por analogia, tal como na criança 
civilizada. Essa tendência os leva a animar o mundo material que os cerca, isto é, a emprestar vida e sentimento às coisas" (MEDEIROS, 1952, p. 43).

O livro Psicologia educacional e desenvolvimento humano: manual de trabalhos práticos, cuja 5a . edição é de 1972, foi escrito por Iva Waisberg Bonow, professora formada em 1934 no Instituto de Educação do Rio de Janeiro, onde mais tarde passou a lecionar a matéria. Criado em 1932, no mesmo dia em que veio a público o Manifesto dos Pioneiros da Educação Nova, o Instituto foi constituído a partir da "integração do Jardim de Infância, Escola Primária, Secundária e de Professores" por meio de decreto assinado por Anísio Teixeira. Sua criação foi norteada pelos princípios da profissionalização docente e do avanço da ciência pedagógica, associados à valorização da escola ativa (VIDAL, 2005).

O livro apresentava-se como repositório da experiência de ensino acumulada pelo grupo de professores que atuava no "Gabinete de Psicologia" do Instituto de Educação. É inovador ao reunir textos redigidos por diversos integrantes da equipe coordenada por Iva Waisberg Bonow e também por sua organização, a qual evidencia orientação para a pesquisa e para a prática profissional no ensino da matéria. O compêndio divide-se em duas partes, um "guia do aluno" e um "guia do professor". A parte dedicada ao aluno tem 10 capítulos, dentre os quais "Como estudar psicologia"; "Como utilizar o teste sociométrico"; "Como fazer entrevistas" e "Estudo de um aluno no seu grupo escolar". A parte do mestre é constituída de 12 capítulos, tais como "Estudo dirigido: principais técnicas"; "Material didático ilustrativo"; “O professor e os testes psicológicos" e "Mapa censitário da turma". O livro traz ainda, como apêndices, um exemplo de programa de psicologia educacional, formulado pela comissão de professores do Instituto de Educação do Rio de Janeiro, uma filmografia comentada e uma listagem de referências bibliográficas para o professor dividida por temas. Assim como seus antecessores, esse livro descreve o desenvolvimento humano como processo de adaptação do indivíduo ao meio e faz a defesa do respeito tanto à individualidade do aluno quanto da consideração das características gerais de cada estágio do desenvolvimento, com suas "reações biológicas e psico-sociais" próprias. Afirmava-se que "Cada aluno é um ser humano em desenvolvimento, com formas pessoais de ajustamento, e condicionado à influência da família e de grupos sociais específicos" (BONOW, 1972, p. 12). Mas o enunciado evolucionista que associava o comportamento da criança ao do homem primitivo está ausente. Em vez disso, o que se encontra é a afirmação das diferenças culturais, sem que o adulto ocidental seja considerado mais evoluído do que outros grupos humanos: 
A observação sistemática dos antropólogos sobre grupos que vivem bastante isolados da nossa cultura (nativos de Nova Guiné - os Manus; ou de povos dos mares do sul - Arapesh, Mundugumor, Tchambuli, etc.) garante esta nova perspectiva. Comportamentos muito diferentes e até opostos aos nossos foram registrados. O que pode parecer anormal ou simplesmente errado na nossa cultura, não o é em outras. Em Samoa, ilha do Pacífico Sul, a criança participa de certos acontecimentos que a nossa educação não permite (assiste ao nascimento de uma criança, por exemplo). E, do nosso ponto de vista, em Samoa não há praticamente neuróticos (BONOW, 1972, p. 10).

O excerto é significativo porque marca a diferença entre este livro e os anteriormente examinados também no nível dos enunciados, ao considerar outras culturas não como atrasadas ou inferiores, mas tão só "diferentes". Mostra os discursos da psicologia educacional começando a tomar distância da biologia ao aproximar-se da antropologia. Nas décadas seguintes, uma parte desses discursos aproximaram-se das ciências humanas, da filosofia, da história e mesmo da literatura, ao mesmo tempo em que fez a crítica da naturalização da ciência psicológica. Contudo, não se tratou de um movimento linear, uniforme ou generalizado. Sua caracterização exigiria um estudo detido, que ultrapassa os objetivos deste capítulo.

$\begin{array}{ll} & * \\ & *\end{array}$

O conjunto dos livros examinados evidencia que a teoria evolucionista constituiu uma referência central para os discursos da psicologia na primeira metade do século XX, tendo perdido legitimidade e força explicativa no interior desses discursos desde então. Ao mesmo tempo permite perceber a heterogeneidade das apropriações feitas pelos autores, pois a hipótese da recapitulação não foi sempre aceita sem restrições, tendo sido ora referendada, ora parcialmente questionada, ora desacreditada nas páginas dos manuais. Parte dos professores afirmaram o paralelismo entre o desenvolvimento da criança e a história da humanidade, ambos pensados a partir da perspectiva moderna, evolutiva e progressista. Como consequência, recomendaram que a educação da criança acompanhasse de perto a história da civilização, conduzindo-a do estágio da inteligência selvagem ou primitiva à condição de adulto racional e civilizado.

Ao se apropriar da teoria evolucionista, a psicologia do desenvolvimento adquiriu legitimidade científica, ao mesmo tempo em que serviu à disseminação da tese do determinismo biológico, principalmente a partir da divulgação dos trabalhos de Spencer, segundo o qual os diferentes grupos humanos apresentavam capacidades desiguais, de acordo 
com a herança recebida de seus antepassados. Embora nos textos examinados não tenham sido encontradas afirmações expressas da inferioridade dos negros, das mulheres e dos pobres, grupos tradicionalmente dominados na sociedade brasileira, são recorrentes os enunciados que estabelecem a distinção entre povos "primitivos" e civilizados nos escritos da primeira metade do século $\mathrm{XX}^{15}$.

Atualmente, como se apresenta a questão do desenvolvimento da criança para a professora e o professor encarregados de sua educação escolar? De alguma maneira, cabe-lhes ajustar o desenvolvimento "natural" ou "individual" da criança ao desenvolvimento "artificial" ou "social” estabelecido pelo currículo escolar. Essa é, afinal, a questão. A propósito, pode-se indagar: Como uma ciência do desenvolvimento pode ajudar? Os discursos da psicologia do desenvolvimento sãos híbridos, neles as verdades sobre as transformações vividas na infância e na adolescência não se separam da intenção de orientar as práticas educacionais, tendo em vista as expectativas sociais relativas à saúde, aprendizado, responsabilidade, sucesso. Esses discursos não dão acesso a qualquer verdade essencial ou universal sobre a natureza humana, antes oferecem um retrato da infância socialmente desejada. Poder-se-ia, contudo, indagar se deveria haver ajuste entre o desenvolvimento individual e o desenvolvimento social. Evidentemente, a resposta a essa questão depende do quanto se valoriza o conjunto de expectativas sociais vigentes.

Mesmo que se reconheça a sua legitimidade, seria preferível, talvez, um ajuste frouxo, não muito apertado, preciso ou científico. Porque, se é fato que a escola deve inserir o indivíduo em um meio social que lhe antecede, é também o espaço propício à renovação da sociedade, ao promover o encontro entre gerações. Seguindo Winnicott, "digamos que um homem ou uma mulher saudáveis sejam capazes de alcançar uma certa identificação com a sociedade sem perder muito de seus impulsos individuais ou pessoais" (WINNICOTT, 2005, p. 9). Um ajuste frouxo corresponderia à ideia de uma certa identificação do aluno com a sociedade, numa medida que não impedisse o surgimento de movimentos espontâneos da criança no espaço compartilhado da escola ${ }^{16}$.

\footnotetext{
${ }^{15}$ Uma análise das manifestações de racismo nos manuais de psicologia educacional foi realizada por Aline Gama Vieira em sua pesquisa de iniciação científica orientada por mim, intitulada $\mathbf{O}$ preconceito racial contido nos manuais de psicologia educacional publicados no Brasil: uma análise dos discursos no período de 1930 a 1960 (VIEIRA, 2018).

${ }^{16}$ Este texto foi aceito para publicação na revista História, Ciências, Saúde -Manguinhos, da Fundação Oswaldo Cruz, Rio de Janeiro.
} 


\section{OS TEMAS DA EVOLUÇÃO E DO PROGRESSO NOS DISCURSOS DA PSICOLOGIA EDUCACIONAL E DA HISTÓRIA DA EDUCAÇÃO}

\subsection{Modernização e progresso da escola republicana}

O processo de difusão mundial da escola de massas, na passagem do século XIX para o século XX, caracterizou-se pela criação e progressiva expansão das escolas seriadas onde se praticava o ensino simultâneo, modalidade na qual um professor levava uma turma de alunos da mesma faixa etária a percorrer o currículo oficial, que deveria ser seguido pelo conjunto das escolas. Caracterizou-se ainda pela tentativa dos governantes de estruturar a formação docente no âmbito das Escolas Normais, por meio da instituição de programas de ensino e da construção de prédios adequados, associados a Escolas Modelo para o aprendizado da prática. Como instituição pública encarregada de transmitir conhecimentos e formar as novas gerações, a escola passou a representar a modernidade e o progresso.

No Brasil, esse processo coincidiu com a Primeira República e teve como modelo a reforma do ensino realizada em São Paulo por Caetano de Campos, que não poupou esforços para promover a modernização da formação docente. Em 1894 inaugurou a nova Escola Normal da Praça, acompanhada da Escola Modelo para o aprendizado das práticas de ensino, importou materiais didáticos e trouxe professores estrangeiros para ensinar às normalistas os novos métodos. Como observou a propósito Marta Carvalho, "Educar era a aspiração uníssona que se levantava em todos os países. Não bastava, contudo, ensinar: era preciso saber ensinar" (1989, p. 26).

Contudo, as primeiras iniciativas republicanas no campo educacional não chegaram a alcançar as expectativas de seus idealizadores. Na década de 1920, os intelectuais que se dedicaram ao exame da questão constatavam a situação de atraso em que o país permanecia, o problema do analfabetismo e da falta de organização do trabalho, cuja expressão mais evidente era a população que migrava da zona rural para a urbana, transformando-se numa massa de analfabetos, pobres e doentes que vagavam pelas cidades, sem trabalho fixo, vivendo em 
condições miseráveis. Para a superação desse quadro desolador, mais uma vez a difusão da escola aparecia como solução à vista. Nos discursos da Associação Brasileira de Educação $(\mathrm{ABE})$, que reunia a elite intelectual interessada na superação dos problemas nacionais,

\begin{abstract}
O presente é reiteradamente condenado e lastimado, sendo caracterizado de modo a fundamentar temores de catástrofes iminentes, que atingirão o país se a campanha educacional não obtiver os resultados desejados. Ao futuro insistentemente se alude como dependente de uma política educacional: futuro de glórias ou de pesadelos, na dependência da ação diretora de uma elite que direcione, pela educação, o processo de transformação do país. (CARVALHO, 1989, p. 55).
\end{abstract}

No início dos anos 1930, com a criação do Ministério da Educação e Saúde, os debates se intensificaram, transformando-se em disputas pelo controle dos fins e dos meios da educação no país. No interior da $\mathrm{ABE}$ as discussões tornaram-se polarizadas, opondo o grupo dos educadores católicos ao dos autointitulados pioneiros da educação nova. Em 1931, realizou-se a IV Conferência Nacional de Educação, aberta por Getúlio Vargas e o recém empossado ministro Francisco Campos, que convocaram os educadores a propor o conceito de educação e as ações que deveriam orientar a nova política educacional. O evento culminou com uma cisão que levou à saída dos católicos da ABE para fundar uma nova organização, a Confederação Católica Brasileira de Educação e, do outro lado, à elaboração do Manifesto dos Pioneiros da Educação Nova, redigido por Fernando de Azevedo (VIDAL, 2013, p. 582-583).

O Manifesto, dirigido ao povo e ao governo, apresentava um caráter simultaneamente diagnóstico e programático. Efeito das discussões dos anos 1920 sobre a dívida republicana (CARVALHO, 1989), acusava a "inorganização" do sistema educacional, consequência da dispersão das iniciativas e da falta de clareza acerca dos fins e dos meios da educação. Defendia a renovação da escola, com vistas a acompanhar o progresso científico e técnico da civilização e recomendava a reorganização do sistema de ensino e a atualização, cientificamente fundamentada, das práticas escolares. No texto do Manifesto, o desenvolvimento do aluno associava-se ao progresso social, e ambos dependiam da adequada reorganização do sistema de ensino. Recaía sobre a escola, instituição encarregada da formação das novas gerações de trabalhadores e cidadãos, a responsabilidade pelo destino da pátria, como expressam as palavras finais do Manifesto:

(...) de todos os deveres que se incumbe ao Estado, o que exige maior capacidade de dedicação e justifica maior soma de sacrifícios; aquele com que não é possível transigir sem a perda irreparável de algumas gerações; aquele em cujo cumprimento os erros praticados se projetam mais longe nas suas consequências, agravando-se à medida que recuam no tempo; o dever mais alto, mais penoso e mais grave é, decerto, 
o da educação que, dando ao povo a consciência de si mesmo e de seus destinos e a força para afirmar-se e realizá-los, entretém, cultiva e perpetua a identidade da consciência nacional, na sua comunhão íntima com a consciência humana (MANIFESTO, 1932, p. 65).

Este capítulo busca caracterizar essa associação entre desenvolvimento do indivíduo e progresso social em duas disciplinas do currículo de formação dos professores, a história da educação e a psicologia educacional. Pretende identificar as aproximações e os distanciamentos entre essas disciplinas no que se refere à presença dos temas da evolução e do progresso. Consiste em uma análise de um conjunto de cinco manuais de psicologia educacional e cinco manuais de história da educação publicados no Brasil entre 1934 e 1972, período em que se intensificou a difusão dos princípios da Escola Nova no país e os discursos em defesa da renovação do ensino cientificamente fundamentada. Recorre à produção acadêmica contemporânea sobre a história da educação aproximada da história cultural, que descreve as circunstâncias históricas nas quais se formaram os objetos, as práticas e os discursos que se tornaram tão familiares em um certo período e em um dado contexto a ponto de serem tomados como naturais ou universais. Tal perspectiva renuncia ao pressuposto de uma história linear e aos princípios de totalidade e de continuidade e desafia as ideias de evolução e progresso que caracterizaram o discurso pedagógico no período considerado. Reconhece ainda as especificidades da cultura escolar, considerada como um conjunto de objetos, discursos e práticas que apresenta configuração e objetivos próprios, embora se relacione com outras configurações. O exame dos manuais inspira-se na análise do discurso, tal como sugerida nos escritos de Foucault, para quem as formações discursivas correspondem a conjuntos de enunciados a propósito dos quais se pode dizer que se caracterizam por seguirem as mesmas regras no que diz respeito à formação dos objetos, dos modos de enunciação, dos conceitos e dos temas e teorias de que tratam. O discurso é assim considerado como uma prática regulada, a qual, ao mesmo tempo em que abre um conjunto de possibilidades, estabelece limites ao que pode ser dito.

Conforme se procurou evidenciar no capítulo anterior, nos discursos da psicologia educacional, o desenvolvimento da criança foi frequentemente descrito à luz da teoria biológica da recapitulação, formulada pelo embriologista Ernest Haeckel na segunda metade do século XIX e difundida nas décadas seguintes no campo das ciências humanas, principalmente por intermédio das obras de Herbert Spencer. De acordo com essa teoria, "a ontogênese reproduz a filogênese", ou seja, cada indivíduo percorre em seu desenvolvimento as etapas de evolução da humanidade. A teoria da recapitulação constituiu um modo de entrada no discurso, ou, nas 
palavras de Foucault, uma estratégia para a formação de enunciados que associavam as mudanças vividas pelas crianças em seu crescimento às transformações históricas ocorridas nas sociedades, aproximando-se a criança pequena do dito "homem primitivo" e fazendo coincidir o termo do desenvolvimento, na idade adulta, com o estágio de civilização do adulto das sociedades industrializadas. Nos manuais de história da educação também se encontram referências a essa teoria, as quais costumam aparecer no capítulo inicial, dedicado à educação do "homem primitivo". Também no âmbito da história da educação a teoria da recapitulação foi apresentada ora como verdadeira, ora questionada e mesmo contestada, apresentando-se como objeto de controvérsia, como se verá adiante a partir do exame conjunto dos manuais de ambas as disciplinas.

\subsection{Considerações teórico-metodológicas}

Os temas da evolução e do progresso marcaram presença na história da educação e na psicologia educacional ensinadas aos professores no decorrer do século XX, e constituíram também o horizonte a partir do qual se instituíram as ciências humanas no século XIX. A psicologia, a sociologia e a antropologia se estabeleceram nesse período e adotaram a física e principalmente a biologia como modelos de ciência para a formulação de suas teorias e procedimentos de estudo. A biologia era então uma ciência transversal, cujo modelo explicativo foi adotado para explicar não apenas a natureza, mas também as sociedades e os indivíduos. O conceito de evolução tornou-se central para a descrição das transformações vividas pelas sociedades desde o dito homem primitivo até o homem civilizado das sociedades ocidentais, assim como das transformações vividas pelo indivíduo da primeira infância à idade adulta, tendo sido empregado também para comparar os indivíduos considerados deficientes mentais aos indivíduos tidos como normais. Como observou Stephen Jay Gould,

\footnotetext{
A recapitulação também proporcionou um critério irresistível a todos os cientistas interessados em estabelecer diferenças hierárquicas entre os grupos humanos. Assim, os adultos dos grupos inferiores devem ser como as crianças dos grupos superiores, pois a criança representa um ancestral adulto primitivo. Uma vez que são como os meninos brancos, os negros adultos e as mulheres são também representantes vivos de um estágio primitivo da evolução dos homens brancos (GOULD, 2003, p. 113).
}

No âmbito da formação de professores, a psicologia se apresentava, desde o início do século XX, como a disciplina em condições de proporcionar fundamentação científica às 
práticas pedagógicas, ao desvendar o processo de desenvolvimento do indivíduo, ao explicitar as necessidades e os interesses das crianças de diferentes faixas etárias e ao permitir acessar as diferenças individuais por meio dos testes. A história, por sua vez, foi valorizada como a matéria que tornava possível aprender com a experiência do passado, de modo a evitar os erros já cometidos e tomar decisões acertadas no presente, tendo em vista preparar um futuro mais auspicioso.

Os temas da evolução e do progresso não constituíram tópicos dos programas de história da educação e de psicologia educacional, não foram objetos de um capítulo específico dos manuais, mas correspondem a uma perspectiva que atravessa os conteúdos dessas disciplinas, aproximando-as, mas também as distinguindo, como veremos a seguir. Embora esta análise não se situe propriamente no campo da história das disciplinas escolares, beneficiase dos trabalhos aí realizados, especialmente das reflexões presentes no texto seminal de André Chervel (1990), na medida que se interessa pelas finalidades do ensino dessas disciplinas nos cursos de formação dos professores. A história permitia aprender com a experiência do passado para construir um futuro melhor; a psicologia consistia no estudo do aluno que proporcionava bases científicas às práticas de ensino. Ambas as disciplinas prometiam um conjunto de verdades cujo domínio conferia maior controle sobre o futuro. Tratava-se de aproveitar as experiências do passado e os conhecimentos científicos sobre a criança para favorecer o pleno desenvolvimento dos alunos do presente, os cidadãos do futuro.

A psicologia revestia-se de um interesse especial, na medida em que, como bem observou Chervel, sendo os alunos de idades diferentes, uma preocupação com a psicologia do desenvolvimento deveria estar presente no ensino de todas as matérias, tendo em vista sua adaptação às idades das crianças. Se, como diz o autor, a psicologia atravessa as disciplinas escolares e diz respeito ao como ensinar alunos de determinada faixa etária, pode-se acrescentar que a história também se faz presente no conteúdo de diversas disciplinas, frequentemente merecendo um capítulo introdutório dos manuais dos cursos de formação docente, e diz respeito ao como tudo começou, ao surgimento da disciplina e às iniciativas dos seus primeiros protagonistas.

A análise dos manuais empregados na formação dos professores permite uma aproximação à cultura escolar que, como bem observou Dominique Julia, não se confunde com outras culturas que lhe são contemporâneas e com as quais se relaciona - religiosa, política, popular - mas guarda a sua especificidade. Na definição já consagrada pelo autor, a cultura 
escolar se refere a "um conjunto de normas que definem conhecimentos a ensinar e condutas a inculcar, e um conjunto de práticas que permitem a transmissão desses conhecimentos e a incorporação desses comportamentos" (JULIA, 2001, p. 10). Os manuais de ensino, frequentemente escritos a partir da experiência dos professores em sala de aula e destinados ao uso escolar, constituem uma fonte privilegiada para o estudo dessa cultura, na medida em que ocupam uma posição intermediária entre as normas para o ensino de uma disciplina, expressas nos programas oficiais, e aquilo que os professores fazem e dizem em sala de aula e que raramente deixou registros, sobretudo quando se considera os períodos mais recuados da história da educação. Mesmo levando-se em conta a advertência do autor de que "o manual escolar não é nada sem o uso que dele for realmente feito, tanto pelo aluno como pelo professor" (JULIA, 2001, p. 34), pode-se admitir que o manual é um indutor de práticas, pois sugere uma sequência dos conteúdos para o ensino da matéria - ainda que essa possa não ser seguida, ainda que o professor possa pular capítulos ou não concluir o livro - e oferece orientações, exemplos, sugestões de atividades etc.

Como observou Décio Gatti, a produção acadêmica brasileira contemporânea sobre a história das disciplinas ministradas nos cursos de formação docente tem se avolumado nos últimos anos, mas as investigações têm incidido principalmente sobre as finalidades ideais do ensino, identificadas a partir da legislação, programas de ensino, periódicos educacionais e manuais. Por outro lado, ainda há relativamente poucos trabalhos voltados à apreensão das finalidades reais do ensino, que se aproximam das práticas em sala de aula, o que se justifica pela dificuldade de se ter acesso aos registros do que se passava no dia-a-dia da escola em cadernos escolares, exercícios, avaliações e livros de ocorrências disciplinares, os quais raramente foram preservados. (GATTI JÚNIOR, 2017). Pode-se considerar, contudo, que os periódicos educacionais, assim como os manuais de ensino, são fontes que permitem uma aproximação maior ao cotidiano escolar do que a legislação ou a obra dos grandes teóricos, o que permite considerá-los como discursos que se situam entre a cultura escolar, a produção científica e as expectativas e demandas sociais feitas à escola. Segundo Catani e Bastos, a imprensa periódica educacional pode contribuir como

(...) um guia prático do cotidiano educacional e escolar, permitindo ao pesquisador estudar o pensamento pedagógico de um determinado setor ou grupo social a partir da análise do discurso veiculado e da ressonância dos temas debatidos, dentro e fora do universo escolar (CATANI; BASTOS, 1997, p. 5).

E, conforme Vivian Batista da Silva, em sua pioneira pesquisa sobre os manuais pedagógicos, 
Poderíamos, então, destacar a hierarquia construída na literatura educacional dividindo os textos em dois níveis, um mais legítimo - ligado à produção de saberes teóricos - e outro mais relacionado às práticas docentes. Essa divisão estruturou os conteúdos dos manuais pedagógicos e foi reconhecida em afirmações como a de Rafael Grisi (1956), ele mesmo escritor de um manual, segundo as quais existiu uma 'pedagogia dos céus', feita pelos teóricos, em academias e bibliotecas, e uma 'pedagogia da terra', realizada pelos professores no dia a dia de suas atividades (SILVA, 2018, p. 44-45).

Nesta análise dos manuais de psicologia educacional e história da educação, segue-se a sugestão de Foucault de ater-se a um exame de superfície do discurso, o que quer dizer que se renuncia a procurar a verdade ou o sentido oculto dos enunciados ou, atrás deles, as intenções não declaradas dos autores. Em vez disso, a partir da identificação das referências à evolução e ao progresso, busca-se estabelecer relações entre os textos no nível dos enunciados, por meio da identificação de aproximações e recorrências, ao mesmo tempo em que se busca descrevêlos em sua dispersão, reconhecendo as diferenças e divergências manifestas entre enunciados (FOUCAULT, 2004).

A análise orienta-se pelas seguintes questões: que aproximações e diferenças se pode identificar entre a história da educação e a psicologia educacional, no que diz respeito aos temas da evolução e do progresso? Esses temas foram referidos a que objetos do discurso em cada caso: tratou-se da evolução dos animais, da criança, do homem, das sociedades? Quem pôde tomar a palavra e assumir a posição de autor em uma e outra disciplina? Em dois casos apresentados adiante, os mesmos autores escreveram manuais de ambas as disciplinas: Theobaldo Miranda Santos, catedrático da Faculdade Católica de Filosofia de Santa Úrsula e do Instituto de Educação do Rio de Janeiro, e Ruy de Ayres Bello, professor catedrático da Universidade do Recife, da Universidade Católica de Pernambuco e do Instituto de Educação de Pernambuco. Que conceitos e considerações teóricas se apresentam nos seus enunciados da história da educação e da psicologia educacional quando se trata desses temas?

Tais questões foram exploradas a partir do exame dos seguintes manuais escritos por professores de história da educação e psicologia educacional, destinados à formação docente: 


\begin{tabular}{|c|c|}
\hline Psicologia Educacional & História da Educação \\
\hline $\begin{array}{l}\text { BELLO, Ruy de Ayres. Introdução à } \\
\text { psicologia educacional. } 2^{\text {a }} \text {. ed., Editora do } \\
\text { Brasil, } 1964 \text {. }\end{array}$ & $\begin{array}{l}\text { BELLO, Ruy de Ayres. Pequena História } \\
\text { da Educação. Editora do Brasil, } 1962 \\
\text { (Coleção Didática do Brasil, v. 19). }\end{array}$ \\
\hline $\begin{array}{l}\text { MEDEIROS, Maurício de. Aspectos da } \\
\text { psicologia infantil. Rio de Janeiro, José } \\
\text { Olímpio, } 1952 \text {. }\end{array}$ & $\begin{array}{l}\text { BRIQUET, Raul. História da Educação: } \\
\text { evolução do pensamento educacional. São } \\
\text { Paulo: Renascença, } 1946 \text {. }\end{array}$ \\
\hline $\begin{array}{l}\text { OLINTO, Plínio. } \\
\text { Guanabara, } 1934 .\end{array}$ & $\begin{array}{l}\text { CAMPOS, Zaira de Moura. História da } \\
\text { Educação. Ribeirão Preto: Ellos, } 1972 \text {. }\end{array}$ \\
\hline $\begin{array}{l}\text { RUDOLFER, Noemy da Silveira. } \\
\text { Introdução à Psicologia Educacional. } 2^{\text {a }} \text {. } \\
\text { ed., São Paulo: Companhia Editora Nacional, } \\
\text { 1961. }\end{array}$ & $\begin{array}{l}\text { PEIXOTO, Afrânio. Noções de História da } \\
\text { Educação. } 3^{\text {a }} . \text { ed., Companhia Editora } \\
\text { Nacional, } 1942 .\end{array}$ \\
\hline $\begin{array}{l}\text { SANTOS, Theobaldo Miranda. Noções de } \\
\text { Psicologia Educacional. Companhia } \\
\text { Editora Nacional, } 1945 \text {. }\end{array}$ & $\begin{array}{l}\text { SANTOS, Theobaldo Miranda. Noções de } \\
\text { História da Educação. Companhia Editora } \\
\text { Nacional, } 3^{\text {a }} \text {. ed., } 1951 \text {. }\end{array}$ \\
\hline
\end{tabular}

Tabela elaborada pela autora.

\subsection{A psicologia nos manuais de história e a história nos manuais de psicologia}

A história da educação e a psicologia educacional como disciplinas independentes foram introduzidas nos currículos de formação docente ao mesmo tempo, ao lado de didática, sociologia, higiene e puericultura, na década de 1920 (ANTUNES, 2007, p. 76), período em que começava a se intensificar a divulgação dos princípios da Escola Nova no país. Na justificativa da reforma do ensino normal de Minas Gerais de 1928, Francisco Campos, então Secretário do Interior, afirmava que a psicologia era matéria indispensável nos currículos de formação dos professores por dar acesso aos conhecimentos sobre a criança (GUIMARÃES; GATTI JÚNIOR, 2012). Ponderava: "Si o destino da escola é a criança, o conhecimento da criança quanto mais completo mais facilitará à escola o exercício da sua missão" (MINAS GERAIS, 1928, p. 75). O autor acrescentava que era principalmente ao desenvolvimento da psicologia que se devia o processo em curso de renovação da escola e dos métodos de ensino: 
Si quisermos encontrar a origem de todo esse movimento, que se assemelha a um ato de despejo das velhas escolas adormecidas na sua prática e na sua rotina, deveremos nos dirigir, não aos práticos do ensino, mas aos Institutos Jean-Jacques, em Genebra, à Universidade de Bruxelas, às Universidades americanas, às Universidades e Seminários da Áustria e da Alemanha, aos psychologos, aos Kofka, aos Stern, aos Spranger, aos Claparède, aos Decroly, aos Dewey (MINAS GERAIS, 1928, p. 79).

A psicologia era associada assim à evolução dos conhecimentos e das técnicas pedagógicas, sem os quais a escola se via estagnada. Também o estudo da história da educação deveria ser feito tendo em vista a preparação do futuro por meio do bom aproveitamento da experiência do passado:

A história da educação terá, ainda, a vantagem de incutir na inteligência dos professores a verdade, que nunca é demais repetir, de que somente a educação tornou possível a civilização do homem, que dela depende o seu presente, como dependerá o seu futuro, e que os povos que não cuidam da educação se acham, por isso mesmo, condenados a essas regressões históricas, de que não conservam a memória porque não deixaram testemunhos (MINAS GERAIS, 1928, p. 80-81).

Essa perspectiva evolutiva e progressista se reproduz nos textos dos manuais, quando se trata de apresentar as contribuições dessas disciplinas para a educação escolar. À história caberia estabelecer a verdade sobre os fatos passados, trazer a experiência acumulada no tempo para ser aproveitada na produção do futuro. A psicologia tinha a oferecer a verdade científica sobre a evolução da criança, permitindo adequar as práticas escolares à sua natureza, tornando o ensino mais eficiente e evitando o desperdício de tempo. Em Noções de História da Educação (1942), Afrânio Peixoto, professor da Universidade do Rio de Janeiro, defendia o estudo da disciplina nos seguintes termos:

\footnotetext{
A educação olha o futuro, nossa preocupação, tentando o aperfeiçoamento dos órgãos desse imenso e imortal organismo, que é a sociedade. Se é problema a resolver na escola ativa da vida o futuro humano, ele só pode ser resolvido com a experiência anterior do passado humano. É a justificação, educativa, pedagógica, do estudo dessa história da educação (PEIXOTO, 1942, p. 10).

A uma educação perfeita corresponderá uma vida feliz, dos homens e da humanidade: é o futuro, o ideal. Como se vem preparando - do passado ao presente, é a história da educação (PEIXOTO, 1942, p. 15).
}

Em Psicologia (1934), Plínio Olinto, psiquiatra da Assistência a Psicopatas e professor da disciplina no Instituto de Educação, assim se pronunciava sobre a sua contribuição para a educação:

(...) é principalmente sobre os princípios de educação que ela vem influindo progressivamente. É sobre as bases da pedagogia que ela concentra as suas conclusões, pois toda a moderna organização da escola do trabalho repousa sobre as observações da psicologia. 
Quantos erros cometeu a pedagogia por falta de psicologia?

Quem poderá ensinar crianças sem lhes conhecer a mentalidade? (OLINTO, 1934, p. $15)$.

No programa para as Escolas Normais formulado a partir da Reforma do Ensino Normal de Minas Gerais em 1928, o programa de história da educação apresenta 25 pontos e há referência à psicologia no ponto XVIII, que trata do início dos cursos normais. Na íntegra, esse ponto do programa que se refere à psicologia é o seguinte:

XVIII - Os começos da instrução normal. A contribuição de Pestalozzi. Desenvolvimento do ensino oral e objetivo. O moderno ensino normal. O Ensino normal da França, na Alemanha, na Bélgica, nos Estados Unidos, na Áustria, no Brasil e, particularmente, no Estado de Minas Gerais. A expansão do ensino normal. A psicologia torna-se uma ciência fundamental. A graduação da instrução primária e a divisão dos alunos em classes (MINAS GERAIS, 1928, p. 282).

Segue-se ao programa de história da educação o de psicologia educacional. Nele não há um capítulo dedicado à história, mas uma atenção privilegiada às mudanças ocorridas ao longo do tempo, em perspectiva evolutiva, a qual atravessa a matéria. O segundo ponto do programa para o primeiro ano, dedicado ao estudo do tema "A psicologia e a educação" consiste em "A evolução biológica do homem e a evolução sociológica do homem" e tem o seguinte conteúdo:

O homem como ser vivo e como ser social. Instintos. Caracteres hereditários. Tendências egoístas e tendências sociais. O homem e o meio. Adaptação ao meio. Imitação. Influências do meio sobre o homem e do homem sobre o meio. O meio cósmico e o meio social. A evolução biológica e a evolução sociológica do homem (MINAS GERAIS, 1928, p. 284).

A partir do exame dos manuais de história da educação, observa-se que os capítulos seguem a ordem cronológica da História Geral: Povos primitivos, Antiguidade, Idade Média, Renascimento, Idade Moderna, Idade contemporânea, com um ou mais capítulos finais dedicados à história da educação no Brasil. E o conteúdo se desenvolve a partir da apresentação dos autores, suas ideias e propostas pedagógicas. Trata-se de história da civilização, mas também de "evolução do pensamento educacional", subtítulo do livro de Raul Briquet.

Em alguns deles (Raul Briquet, 1946; Theobaldo Miranda Santos, 1951, Ruy de Ayres Bello, 1962) a "educação psicológica" aparece como um capítulo, que corresponde ao período do final do século XVIII à primeira metade do século XIX e aos autores Froebel, Herbart e Pestalozzi. Nesses livros, o capítulo dedicado à educação psicológica é anterior àquele dedicado à "educação científica”, de que são representantes Spencer, teórico do evolucionismo e Comte, da segunda metade do século XIX. Esse aspecto da estruturação dos manuais 
surpreende, quando se leva em conta que nos compêndios de psicologia educacional, a psicologia é apresentada como a disciplina que pode proporcionar bases científicas para a pedagogia e teve início quando Wundt criou o primeiro laboratório de psicologia na Universidade de Leipzig, Alemanha, em 1879. Assim, o exame conjunto dos manuais das duas disciplinas evidencia diferenças nos modos de se referir às relações entre psicologia e a educação. Os manuais de história da educação dedicam um capítulo à emergência histórica de propostas pedagógicas que trazem uma preocupação com a psicologia da criança a partir de meados do século XVIII, com Pestalozzi, Herbart e Froebel, que são referidos como representantes da "educação psicológica" ou de uma "pedagogia de sentido psicológico" como período específico da história da educação. Já os manuais de psicologia educacional, quando fazem referência à história da disciplina, consideram como seu início não o surgimento de uma pedagogia devotada à psicologia da criança, mas a criação do laboratório de psicologia experimental por Wundt. Esse aspecto chama ainda mais atenção quando se manifesta em manuais das duas disciplinas escritos pelo mesmo autor, como é o caso de Theobaldo Miranda Santos.

Noções de História da Educação contém um capítulo intitulado "A educação psicológica", no qual apresentam-se os "educadores psicológicos" representativos dessa fase, que viveram de meados do século XVIII a meados do século XIX: Pestalozzi (1746-1827); Herbart (1776-1841) e Froebel (1782-1852). Sobre "a tendência psicológica na educação" o autor esclarece que

Com o raiar do século XIX, a influência da psicologia sobre a educação, isto é, a preocupação de fazer o trabalho educativo gravitar em torno do espírito da criança, começa a ganhar terreno. Indubitavelmente a obra de Rousseau muito concorreu para que essa tendência se afirmasse e desenvolvesse. A educação psicológica representou mesmo uma tentativa de dar aos princípios do naturalismo pedagógico do mestre de Genebra uma formulação científica e um caráter de processo escolar prático (SANTOS, 1951, P. 334).

O mesmo se passa na Pequena História da Educação, de Ruy de Ayres Bello. O capítulo intitulado “A Pedagogia de sentido psicológico” inicia-se como segue:

Graças à influência de Rousseau, que havia insistido na necessidade de se basear o processo educativo nas peculiaridades mentais da criança, começaram os pedagogos e educadores a se preocupar com o estudo sistemático da natureza infantil, como ponto de partida para o desenvolvimento de suas teorias e atividades educativas. Essa preocupação aparece em todos os pedagogos de qualquer modo influenciados pelas teorias do Emílio, mas é principalmente em Pestalozzi e em seus discípulos Herbart e Froebel que ela é levada às últimas consequências. (BELLO, 1962, p. 196). 
A partir do exame dos manuais de história da educação e de psicologia educacional identifica-se, portanto, um desnível que corresponde a aproximadamente um século de distância entre a educação psicológica como período da história da educação em que emerge o interesse pela formulação de métodos de ensino adaptados às características e necessidades da criança e a psicologia educacional, como ciência aplicada que passaria a compor o currículo de formação dos professores.

Na introdução de seu manual dedicado à psicologia educacional, Theobaldo Miranda Santos se refere a autores que viveram a partir de meados do século XIX e se dedicaram à psicologia experimental, dentre os quais Wundt, Stanley Hall, Claparède, Betscherew, Pavlov, Binet e Simon etc. como os pioneiros da psicologia. Enquanto em seu manual de história da educação, os capítulos se organizam a partir da apresentação dos autores e suas ideias pedagógicas em sequência cronológica, no manual de psicologia educacional estrutura-se a partir da descrição esquemática da disciplina como ciência: observação, experimentação, aparelhos, métodos. Em sua Introdução à psicologia educacional, Ruy de Ayres Bello, por sua vez, faz os primórdios da psicologia recuarem a Platão e afirma que Aristóteles é “considerado o verdadeiro fundador da Psicologia, indicando o seu objeto e o seu método e usando pela primeira vez esse nome" (1962, p. 23). Para esse autor, os estudos dessa disciplina aplicados à educação atingem o auge no século XX, designado como o século da criança, com a ampliação e a intensificação dos trabalhos levados a efeito por Binet e Simon, Stern, Muller, Lippman, Decroly, De Sanctis, Claparède, Dewey, Thorndike, Ballard e outros.

Já em História da Educação (1972) de Zaíra de Moura Campos, professora de história da educação da Faculdade de Filosofia, Ciências e Letras da Universidade Moura Lacerda, em Ribeirão Preto, há um tópico intitulado "Pedagogia psicológica e experimental", o qual está incluído no penúltimo capítulo da obra "A Pedagogia do século XX”. Trata-se de um tópico sumário, no qual a autora explica o seguinte:

\footnotetext{
A pedagogia psicológica é produto de nosso tempo. Entretanto, bem antes do século, já se fizeram importantes observações psicológicas sobre o desenvolvimento da criança (Rousseau).

Mas, num estudo mais científico da criança e sua aplicação à educação, data do fim do século XIX, começo do século XX (CẢMPOS, 1972, p. 171).
}

Nesses termos, a pedagogia psicológica referida pela autora já não corresponde àquela apresentada nos livros de Raul Briquet (1946); Theobaldo Miranda Santos (1951), Ruy de Ayres Bello (1962), mas à pedagogia associada à psicologia experimental, aproximando-se assim do discurso dos manuais de psicologia educacional considerados, dentre os quais o de 
Plínio Olinto, quase quatro décadas anterior, para quem a psicologia tornou-se moderna ao se separar da filosofia e aproximar-se da biologia:

\begin{abstract}
Os estudos modernos tendem a dar a psicologia uma orientação mais firme, mais concreta, ou, pelo menos, desviá-la do caminho das cogitações abstratas onde ela se debateu por muito tempo, vaga, indecisa, fazendo corpo comum com a filosofia.

Os psicólogos modernos resolveram aproximá-la mais da biologia e os resultados foram animadores. (OLINTO, 1934, p. 14).
\end{abstract}

A propósito do manual de Plínio Olinto, vale observar que, enquanto nos manuais de história de Briquet, Santos e Bello, a educação psicológica correspondia a um intervalo da linha do tempo da história da educação, nesse livro as diferentes épocas históricas se distinguem pela valorização social de um atributo psicológico específico, como segue:

A sociedade também sujeita a seus ritmos põe em destaque, periodicamente, certos tipos como padrões da época.

Quando a força foi a qualidade mais apreciada pelos homens, apareceram os heróis; quando a bondade floresceu, tivemos os tempos dos santos; no período da cultura, vieram os sábios, ultimamente os homens de ação se notabilizam.

Ford passa a ser um símbolo da época.

Lutadores, místicos, pensadores, idealistas, contemplativos, cederam lugar aos utilitaristas.

(OLINTO, 1934, p. 267).

Merece menção especial o livro Introdução à Psicologia Educacional, de Noemy da Silveira Rudolfer, professora de psicologia na Escola Normal Caetano de Campos e posteriormente na Universidade de São Paulo, pois corresponde a uma história da disciplina psicologia educacional. Nesse compêndio, os capítulos referem-se aos diferentes períodos de desenvolvimento da matéria, em vez de se dedicarem à exposição dos diferentes aspectos do funcionamento psicológico - hábito, atenção, afetividade, inteligência, linguagem etc. - como era típico nos manuais do gênero. Esse livro original é resultado de tese elaborada pela autora por ocasião do seu concurso de ingresso na USP e foi motivado pela sua necessidade de se orientar entre as diferentes teorias, conforme ela registrou no prefácio:

No início dos meus estudos, a despeito da orientação firme de meus mestres, foi sempre de perplexidade o estado de espírito com que me aventurei na leitura de qualquer obra no campo da Psicologia, tão grande era o senso das diferenças de pontos de vista e tão intensa a compreensão de que o aceitar uma doutrina ou, melhor, o filiar-se a uma escola seria por em risco a objetividade necessária nos domínios da Psicologia. Foi natural, portanto, que, em resultado, o estudo da história da Psicologia, como indispensável, me atraísse profundamente. Três conclusões tirei desse estudo: em primeiro lugar, a de que, na multiplicidade de orientações psicológicas, só um ponto de vista eclético pode ser de auxílio; em segundo, a de que a compreensão das psicologias modernas depende de uma compreensão da evolução histórica dessa ciência; e finalmente, a de que apenas dois critérios parecem garantir 
a busca do melhor em Psicologia - o emprego do método científico e a fertilidade no decorrer dos tempos (RUDOLFER, 1961, p. XV-XVI). (destaques nossos).

Diversas foram as associações entre a história da educação e a psicologia educacional, assim como as expressões empregadas pelos autores para se referir a essas associações, como se pode observar a partir do exame desse conjunto de livros. Nos manuais de história, é recorrente a apresentação de uma educação psicológica que corresponde ao período em que o estudo da criança adquire centralidade no pensamento educacional. Nos manuais de psicologia educacional, era frequente recorrer-se à história para destacar a própria psicologia como ciência moderna, sob o pano de fundo das especulações filosóficas. Em comum, ambas as disciplinas alinhavam experiência, ciência, evolução e progresso como vetores que indicavam o horizonte da educação.

\subsection{Evolução e progresso nos manuais de história da educação e psicologia educacional}

Três dos seis manuais de história da educação examinados dedicam suas páginas iniciais à apresentação da "educação primitiva" ou "educação dos selvagens e primitivos", enquanto os demais desconsideram esse tema e iniciam pela Grécia Antiga. A leitura conjunta dos capítulos sobre a educação dos primitivos nos manuais evidencia um aspecto da controvérsia entre educadores pioneiros e católicos referida no início deste capítulo, quando se trata do evolucionismo e da teoria da recapitulação. Afrânio Peixoto, signatário do Manifesto dos Pioneiros da Educação Nova, afirmava que pouco se sabia sobre os povos selvagens e primitivos, mas muito se especulava sobre a bondade ou maldade original do homem no âmbito das religiões e da filosofia. Acerca da teoria da recapitulação, o autor ponderava:

\footnotetext{
as crianças não são reduções humanas de adultos, como os selvagens não são homens apenas menos educados de outrora. As crianças têm órgãos que lhes fazem o desenvolvimento, outros que se aperfeiçoam, outros que, já sem função, deperecem mais tarde... O adulto é o que resulta, outro ser, saído do primeiro, como o fruto da flor, sequência, e não múltiplo (PEIXOTO, 1942, p. 10)
}

Apesar disso, aproximava a criança do selvagem ao se referir à sua mentalidade prélógica, assim como aproximava o selvagem dos animais no que dizia respeito à adaptação ao meio ambiente e ao expressivo desenvolvimento dos sentidos que uns e outros apresentavam: 
O selvagem está num período rudimentar de mentalidade em que a relação entre as cousas é mística, é metafísica, é pré-lógica (não “anti-lógica” ou “ilógica”), diz LevyBruhl, cuja filosofia (1910) esclarece estes assuntos. Jean Piaget renova a psicologia infantil, seguindo-lhe as pegadas, estudando o pensamento simbólico, de primitivo infantil, pré-lógico (PEIXOTO, 1942, p. 11).

A educação selvagem é apenas uma adaptação ao ambiente. Como o ambiente não muda, diz Monroe, a educação ficará estacionária, donde, afirmara Spencer, a imprevisão primitiva. A dinâmica educacional cultiva, pela didática psicológica, as faculdades perceptivas: os sentidos têm como em certos animais, acuidade notável (PEIXOTO, 1942, p. 12).

Theobaldo Miranda Santos e Ruy de Ayres Bello, representantes dos educadores católicos, expressavam a sua discordância em relação a esses aspectos, recusando as teses biológicas da recapitulação e do evolucionismo. Bello entendia que Tristão de Athayde (Alceu Amoroso Lima), "tendo considerado todos os modernos ensinamentos científicos sobre a mentalidade primitiva, pôde chegar a uma conclusão que admiravelmente sintetiza tudo o que a ciência moderna realmente estabeleceu a respeito" (1962, p. 10) e em seguida apresentava uma citação desse autor que já aparecia registrada no manual de Santos na década anterior:

\footnotetext{
'Mostraram-se estas, conclui Tristão de Athayde, à luz de uma observação verdadeiramente científica, já não mais modelos de inocência e pureza, nem criaturas ainda animalizadas. E sim raças inferiores, em civilização material e progresso moral, mas perfeitamente humanas, cuja história possui variações muito ricas, cuja evolução é muito complexa, cuja psicologia possui uma relativa riqueza e cujas instituições estão longe de ter sofrido a marcha progressiva, delineada por observações insuficientes e conclusões precipitadas' (apud BELLO, 1962, p.10 e SANTOS, 1951, p. 29).
}

Ruy de Ayres Bello, ao tratar as fontes históricas da educação "primitiva”, explicava que os estudiosos buscavam obter informações sobre as sociedades "primitivas" por meio dos vestígios deixados por elas e a partir da observação dos "selvagens" contemporâneos. Em seguida referia-se às críticas já realizadas a esse método por, entre outros, Robert Lowie, professor da Universidade da Califórnia, segundo o qual "mesmo os grupos culturais mais singelos da atualidade, contam com um longo passado, tendo por isso, progredido muitíssimo desde o seu estádio inicial de civilização" (apud BELLO, 1962, p. 12). Apesar disso, considerava que os estudos sobre a educação do homem "primitivo" a partir da análise das práticas educativas dos "selvagens" contemporâneos tinham "uma significação analógica":

Diz Roger Gal que os selvagens modernos nos oferecem 'uma imagem dos grupos sociais onde nenhuma instituição especializada era designada para a educação dos jovens', o que quer dizer, onde a educação se apresentaria sob a sua forma mais simples, talvez apenas esboçada. Por esse modo, se põe a questão nos seus justos termos que, em síntese, vêm a ser os seguintes: mesmo que os selvagens atuais não sejam mais primitivos, a educação entre eles praticada é, provavelmente a educação primitiva, isto é, a educação na sua forma mais singela, mais rudimentar. Dessa maneira, poderemos, utilizando o processo da analogia, que é sempre hipotético, 
partir da observação do fato educacional, tal como ocorre entre os selvagens contemporâneos, cuja vida social nos oferece, pelo menos, uma 'imagem' dos grupos primitivos, para o estudo das formas mais rudimentares, e, de certo modo, embrionárias, da educação (BELLO, 1962, p. 13).

No livro de Afrânio Peixoto, chama atenção o preconceito em relação aos negros na mesma passagem em que se procura negar as diferenças de capacidades entre crianças negras e brancas. Isso se manifesta no capítulo sobre a educação dos primitivos, quando o autor se refere à aplicação de testes de inteligência em crianças negras na África do Sul e Austrália. Embora afirme não haver diferença "natural" de desempenho, manifesta-se no seu texto a associação entre criança negra e homem "primitivo", assim como a hierarquização entre culturas:

Contudo, um fato a reter: tests de inteligência aplicados na Austrália e na África do Sul às crianças negras mostraram que não são inferiores aos meninos brancos. Todas as crianças, não importa as raças, são bem dotadas, graças a bons olhos e bons ouvidos que captam a vida; depois é que é... a doença em uns, uma sociedade amorfa na generalidade, um ensino, dogmático nos meios educados, fazem o resto - a desigualdade racial do mundo, que é mais humana, que natural (PEIXOTO, 1942, p. 13).

A História da Educação, escrita por Raul Briquet, professor da Faculdade de Medicina da USP e professor de "Educação Nacional" da Escola Livre de Sociologia e Política de São Paulo, não apresenta um capítulo sobre a educação "primitiva”, mas em seu capítulo "A educação científica", refere-se à teoria da recapitulação, ao tratar da proposta pedagógica de Spencer: "A educação da criança deve ajustar-se ao modo e à ordem seguida pela evocação da humanidade, consideradas do ponto de vista histórico" (BRIQUET, 1946, p. 139). Ao tratar da contribuição de Spencer, o autor afirma: "O mérito da educação espenceriana está em ter pregado, já em 1855, nos seus Princípios de Psicologia, a importância dessa ciência indispensável para se edificar a teoria científica da educação" (idem, p. 141), explicitando assim de uma outra maneira a presença da psicologia no discurso da história da educação destinada à formação docente: a descoberta da importância da psicologia para a educação como um acontecimento ou um feito registrado na história da educação.

Em Introdução à psicologia educacional, livro no qual Noemy Silveira Rudolfer discorre sobre a história da disciplina, apresenta-se um enunciado recorrente no discurso dos manuais do gênero, segundo o qual foi no século XIX que a psicologia se tornou científica, ao aproximar-se da biologia, particularmente do evolucionismo. Para Noemy Rudolfer, foi então que a disciplina adotou um método experimental e passou a empreender estudos sobre o psiquismo animal que levaram à formulação de teorias da aprendizagem, bem como às 
investigações sobre o psiquismo inato e as diferenças individuais (RUDOLFER, 1961, p. 74). A autora afirmava que Spencer antecipou-se a Darwin na divulgação do evolucionismo e contribuiu tanto para a sua aceitação na psicologia como para o surgimento da "psicologia genética, comparativa e diferencial", ajudando a tornar evidente a necessidade de levar em conta o fator do desenvolvimento na educação. Acrescentava que a teoria evolucionista de Darwin teve três consequências importantes para a psicologia: uma ênfase na comparação interessada em demonstrar a evolução psíquica; uma atenção às diferenças individuais, tendo em vista a identificação do mais apto e o estudo do desenvolvimento individual com o objetivo de estabelecer suas relações com o desenvolvimento da espécie. Sintetizava afirmando que "A psicologia comparativa, a diferencial e a genética são filhas do evolucionismo" (RUDOLFER, 1961, p. 83).

Deve-se lembrar, porém, que, assim como na história da educação, na psicologia educacional a teoria da recapitulação também foi objeto de controvérsia. Em Psicologia (1934), de Plínio Olinto, aparecia como expressão da verdade: "E cada um repete, nos limites de suas possibilidades, o esforço que empregou a humanidade na sua socialização, pois é sabido que o indivíduo refaz, abreviadamente, a marcha geral da evolução da espécie" (OLINTO, 1934, p. 254). Em Aspectos da psicologia infantil (1952), de Maurício de Medeiros era apresentada como lei: "Há uma lei em biologia que sintetiza o resultado de longas observações. Segundo essa lei a evolução do indivíduo reproduz abreviadamente a evolução da espécie. Em termos mais bombásticos, porque científicos, se diz: 'a ontogênese reproduz a filogênese"'. (MEDEIROS, 1952, p. 39). O autor recorria à teoria da recapitulação para explicar a atividade imaginativa das crianças pequenas, comparando-a à dos povos primitivos: “A observação dos povos primitivos neles assinala uma tendência ao raciocínio por analogia, tal como na criança civilizada. Essa tendência os leva a animar o mundo material que os cerca, isto é, a emprestar vida e sentimento às coisas" (MEDEIROS, 1952, p. 43). Por outro lado, como já foi dito a propósito da história da educação, os educadores Theobaldo Miranda Santos e Ruy de Ayres Bello punham em dúvida a teoria da recapitulação. Em seus manuais dedicados à psicologia educacional, esse questionamento se apresentava quando se referiam à questão do jogo:

Dentre as teorias que pretendem explicar o jogo pelo passado, está a de Stanley Hall, que liga a atividade lúdica à 'lei biogenética' de Haeckel. Segundo essa lei, a evolução do indivíduo recapitularia a evolução da espécie. O jogo seria então, uma revivescência de certas formas de atividade das sociedades primitivas, tornadas caducas, em face da evolução da humanidade. 
Essa explicação do jogo pode, talvez ser aceita por todos aqueles que admitem a teoria da recapitulação, mas essa teoria é apenas, uma hipótese, que tem, aliás, contra si a opinião da maioria dos cientistas (BELLO, 1964, p. 99).

Apesar das restrições formuladas ao evolucionismo e à teoria da recapitulação, Theobaldo Miranda Santos não deixava de apresentar a sua própria versão do desenvolvimento individual associado à evolução, ao dizer:

\begin{abstract}
A criança e o adolescente possuem, em germem, todas as virtualidades do adulto, porém, sob uma forma própria, que poderá variar a cada momento do seu desenvolvimento e modificar-se sob a influência do meio e da educação. A criança e o adolescente devem ser, portanto, considerados como seres em contínua evolução, em lenta mas progressiva ascensão à maturidade psíquica do adulto (SANTOS, 1945, p. 142).
\end{abstract}

Segundo a concepção do autor, a educação tinha o poder de alterar o curso do desenvolvimento das crianças e dos adolescentes, de modo que cabia aos adultos encarregados da sua educação direcioná-los, tendo em vista os fins mais elevados da educação (SANTOS, 1945, p. 143).

A análise conjunta dos manuais evidencia que, embora os temas associados da evolução e do progresso sejam recorrentes, o evolucionismo e a teoria da recapitulação eram objetos de controvérsia. O ponto central do debate era a aproximação que se estabelecia no evolucionismo entre a criança e as culturas ditas "primitivas" e os animais. Enquanto essa aproximação era confirmada em parte dos manuais, foi recusada pelos educadores católicos, que realçavam a essência humana presente na criança e no homem "primitivo" desde o início, por meio da qual estabeleciam a sua separação do reino animal. $\mathrm{O}$ exame deste conjunto de manuais não permite, contudo, estabelecer uma simples oposição entre católicos e escolanovistas quanto às concepções de evolução e progresso. Isso porque houve educadores partidários da educação laica que, embora endossassem o evolucionismo, também fizeram restrições à teoria da recapitulação, como se procurou mostrar a partir da descrição do manual de história da educação de Afrânio Peixoto. Essas restrições diziam respeito sobretudo à continuidade que essa teoria estabelecia entre a criança e o adulto, entre o homem "primitivo" e o homem "civilizado". Questionavam-se essas pressuposições, chamando-se atenção para as particularidades da criança em face do adulto, assim como observando-se que o chamado homem "selvagem" vivendo no mundo contemporâneo não correspondia ao passado do homem “civilizado", já que também o seu modo de existência se alterara com a passagem do tempo. Sendo assim, era apenas por "analogia" que se admitia procurar compreender as formas de 
educação do passado remoto por meio da observação das práticas dos "selvagens" contemporâneos.

A oposição entre católicos e escolanovistas também não foi total, pois, apesar da controvérsia em torno do ponto específico da aproximação entre os seres humanos considerados menos desenvolvidos e os animais, era comum nos discursos de uns e outros a associação entre desenvolvimento, civilização e progresso, assim como era compartilhada a convicção de que a educação cientificamente fundamentada podia promover tanto o desenvolvimento da criança como o progresso da sociedade.

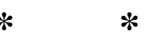

A associação entre educação, ciência e progresso, recorrente no discurso educacional da Primeira República e no Manifesto dos Pioneiros da Educação Nova, manifestou-se também no conteúdo dos manuais da história da educação e da psicologia educacional considerados neste capítulo. Nos manuais de história da educação, a educação psicológica aparecia como um período da história da educação, situado a partir de meados do século XVIII, quando se manifestava na pedagogia a preocupação com a criança e o seu desenvolvimento. Nos manuais de psicologia educacional, costumava-se privilegiar a emergência da psicologia experimental, a partir da segunda metade do século XIX, como período de surgimento da disciplina.

Considerava-se que tanto a psicologia como a história tinham as suas próprias contribuições a oferecer à educação do futuro, ou à preparação do futuro por meio da educação. A história era valorizada porque permitia aprender com a experiência e evitar os erros do passado. A psicologia era necessária para dar respaldo científico às práticas educativas. $\mathrm{Na}$ história, a perspectiva progressista aparecia associada ao evolucionismo quando se tratava da tentativa de reconstituir a experiência educativa dos povos do passado mais remoto, designados como "primitivos". $\mathrm{Na}$ psicologia apresentava-se quando se procurava descrever o desenvolvimento da criança, do início à fase adulta.

Apesar da controvérsia entre católicos e escolanovistas quanto à propriedade de se estabelecer uma aproximação entre a criança, o "selvagem" ou "primitivo" e os animais, e dos 
questionamentos feitos à teoria da recapitulação por representantes das duas vertentes, a perspectiva progressista que levava a hierarquizar indivíduos e sociedades, estabelecendo uma linha evolutiva da criança ao adulto e do "primitivo" ao civilizado caracteriza o conjunto dos livros examinados.

A psicologia educacional evolutiva, se, por um lado, contribuiu para evidenciar a necessidade de adaptar o ensino às idades dos alunos, por outro lado serviu de argumento para a defesa do oferecimento de ensinos desiguais, adaptados às suas (im)possibilidades. Desse modo frequentemente concorreu para o aprofundamento das desvantagens dos grupos socialmente desfavorecidos, cujas crianças foram quase sempre avaliadas como menos desenvolvidas. A história da educação evolutiva, se, por um lado, pretendeu proporcionar aos professores acesso à experiência acumulada, contribuindo para que se evitassem os "erros" do passado, por outro lado procurou estabelecer de antemão a orientação do porvir, eventualmente restringindo as possibilidades de se vislumbrarem outras alternativas de futuro ${ }^{17}$.

\footnotetext{
${ }^{17}$ Este texto foi aceito para publicação e integrará o dossiê "Manuais disciplinares, discursos pedagógicos e formação de professores" da Revista de História da Educação. Porto Alegre: Associação Sul-Rio-Grandense de Pesquisadores em História da Educação (ASPHE).
} 


\section{ESCOLA, PSICOLOGIA E DEMOCRACIA NOS DISCURSOS PEDAGÓGICOS}

Este texto caracteriza as relações que se estabeleceram entre escola, psicologia e democracia nos discursos da educação e da psicologia educacional na Era Vargas, período controverso na história do Brasil, em que as iniciativas de modernização do país e a extensão dos direitos dos trabalhadores coexistiram com o autoritarismo político e a aproximação do governo do fascismo europeu. No plano educacional, foram anos de intensa divulgação do ideário da Escola Nova e de produções intelectuais empenhadas em compreender as especificidades do povo brasileiro, caracterizado pela mestiçagem de raças e a heterogeneidade de culturas. A análise detém-se especificamente sobre os enunciados que manifestavam a expectativa de que a psicologia poderia proporcionar fundamentação científica para a educação e a sociedade democráticas.

Toma-se como fontes nucleares dois textos muito conhecidos e dois textos quase ignorados no campo educacional. Os primeiros correspondem ao livro Introdução ao Estudo da Escola Nova (1930), de Lourenço Filho, professor de psicologia na Escola Normal de São Paulo e ao Manifesto dos Pioneiros da Educação Nova, redigido em 1932 por Fernando de Azevedo, professor de sociologia na mesma instituição e assinado por diversos educadores e intelectuais prestigiados na época. Os outros são os artigos "Como pode a escola contribuir para a formação de atitudes democráticas?" (1944) e "Dos perfis caracterológicos como elemento de educação democrática" (1945), ambos da autoria da psicóloga russa Helena Antipoff, que atuou como professora de psicologia na Escola de Aperfeiçoamento de Professores em Belo Horizonte.

Os quatro textos selecionados para a análise podem ser considerados como pertencentes ao discurso da Escola Nova, o qual, embora já não corresponda ao discurso contemporâneo no campo da educação, permanece como uma referência fundamental para a 
produção atual, o que sugere a existência de certa nostalgia em relação a seus ideais e, por vezes, a tendência em considerar o período atual como a continuação do movimento protagonizado pelos pioneiros da Escola Nova, como observou Natália Gil no texto "Escola democrática, meritocracia e seletividade" (2019). Entre esses ideais, um particularmente importante correspondia à esperança de que as respostas buscadas pelas ciências humanas para os problemas sociais permitiriam superá-los e conduzir-nos em direção ao desenvolvimento e ao progresso, assim como à conquista da igualdade de oportunidades, como fundamento da democracia. Considera-se que os textos selecionados para essa análise podem contribuir para um diagnóstico do presente, na medida em que, para empregar as palavras de Foucault em $A$ arqueologia do saber, esses discursos

\begin{abstract}
começam a deixar justamente de ser os nossos, seu limiar de existência é instaurado pelo corte que nos separa do que não podemos mais dizer e do que fica fora da nossa prática discursiva; começa com o exterior da nossa própria linguagem; seu lugar é o afastamento de nossas próprias práticas discursivas. Nesse sentido, vale para nosso diagnóstico (2004, p. 148).
\end{abstract}

\title{
6.1 Considerações teórico-metodológicas
}

Tendo em vista as considerações de Foucault em A arqueologia do saber (2004), a análise que está sendo proposta renuncia aos pressupostos da continuidade e da evolução, de modo que os discursos atuais sobre educação, psicologia e democracia não são tomados como a continuação ou o desenvolvimento dos discursos do passado. A partir da análise dos textos mencionados, pretende-se caracterizar como a psicologia foi mobilizada no discurso dos educadores escolanovistas em sua defesa de uma educação democrática, tendo em vista estabelecer eventuais aproximações e distanciamentos entre a luta dos educadores de então e a luta tal como se configura para nós atualmente. Sustenta-se que essa diferença pode estar relacionada aos modos de estabelecer conexões entre os termos natureza, verdade e democracia. Para os escolanovistas tratava-se de fazer com que as "verdadeiras aptidões", dadas pela natureza, se sobrepusessem aos privilégios sociais, garantindo oportunidades a todos aqueles que se mostrassem capazes, independentemente de sua condição social. A luta atual, em vez disso, consiste em problematizar a associação entre natureza e verdade, ordem natural e ordem social. Consiste em sustentar que a formação das subjetividades e dos modos de vida em sociedade não corresponde a uma suposta natureza humana ou a quaisquer determinações 
naturais, mas variam conforme contingências históricas e políticas, resultam da inventividade humana e são, portanto, transformáveis.

Foucault propõe-se a considerar a especificidade do nível discursivo, o que quer dizer que toma o discurso como "coisa" dotada de espessura própria, e não como reflexo ou representação, seja das coisas do mundo, seja do pensamento dos autores. Seguindo o autor, esta análise não toma os discursos como documentos que se referem a outras coisas $-a$ psicologia, suas teorias, seus conceitos, suas verdades, seus usos legítimos ou ilegítimos; $a$ democracia, sua definição, seus avanços e retrocessos, nem mesmo os autores, suas concepções, preocupações e interesses. Trata-se de examiná-los como coisas raras, dotadas de uma história e de características próprias, como se fossem monumentos, cujos modos de fabricação e cujas propriedades importa compreender. Isso quer dizer que os discursos não são compreendidos como o resultado esperado do desenvolvimento da consciência dos homens, mas como acontecimentos. A propósito dos enunciados, Foucault escreve:

Um enunciado é sempre um acontecimento que nem a língua nem o sentido podem esgotar inteiramente. Trata-se de um acontecimento estranho, por certo: inicialmente porque está ligado, de um lado, a um gesto de escrita ou à articulação de uma palavra, mas, por outro lado, abre para si mesmo uma existência remanescente no campo de uma memória, ou na materialidade dos manuscritos, dos livros e de qualquer forma de registro; em seguida, porque é único como todo acontecimento, mas está aberto à repetição, à transformação, à reativação; finalmente, porque está ligado não apenas a situações que o provocam, e a consequências por ele ocasionadas, mas, ao mesmo tempo, e segundo uma modalidade inteiramente diferente, a enunciados que o precedem e o seguem (FOUCAULT, 2004, p. 31-32).

Para caracterizar os enunciados, a análise permanece na superfície do discurso, o que significa que renuncia a atravessar o discurso para alcançar as próprias coisas ou à tentativa de compreender as motivações não declaradas ou os pensamentos não formulados do autor, aquém ou além do que foi dito. Também não pretende determinar a veracidade ou falsidade dos enunciados. Em vez disso, busca estabelecer as relações observáveis entre enunciados, assim como entre acontecimentos discursivos e não discursivos.

Em “A Psicologia Social como uma ciência da democracia”, Nikolas Rose, recorrendo à perspectiva de análise do discurso foucaultiana, observa que a palavra democracia é recorrente nos discursos da psicologia nas décadas de 1930 a 1950 e pergunta-se: Como compreender essa presença? Em seguida, sugere algumas alternativas: Corresponderia simplesmente a uma homologia entre o discurso político e o discurso científico, "algo talvez 
pouco surpreendente em décadas marcadas pela contestação, cheias de movimentos, forças e ideologias declaradamente antidemocráticas"? Seria o efeito da biografia dos psicólogos, uma vez que um grupo de judeus em fuga da Alemanha nazista teve um papel importante para o desenvolvimento da disciplina? Tratar-se-ia, em vez disso, da "manifestação da consciência liberal dos psicólogos americanos, de sua fé ingênua em suas próprias instituições de governo e na progressiva e iluminada contribuição que a pesquisa social racional e científica poderia fazer para resolver os problemas do mundo"? (2011, p. 164). Ou essa presença seria melhor compreendida como um mero recurso retórico, uma "questão de prefácios e conclusões", para dar uma tintura de preocupação social a um núcleo de conteúdo constituído pela descrição dos resultados de pesquisa empírica, orientada exclusivamente pelo princípio do rigor científico? O autor rejeita essas hipóteses e propõe uma outra perspectiva de análise para alcançar o cerne da questão. Procura evidenciar que, longe de ser um aspecto menor ou marginal dos discursos psicológicos, as referências à democracia se explicam porque a psicologia se constituiu gradativamente como uma ciência capaz de fornecer respostas para problemas que atormentam a democracia. Esses problemas dizem respeito a como governar respeitando-se os ideais de liberdade, igualdade, respeito ao indivíduo, autonomia, responsabilidade social e autoridade legítima. A psicologia tornou possível traduzir esses "princípios da democracia do domínio da ética para o da esfera das verdades científicas e da expertise racional", possibilitando a criação de programas de governo fundamentados em conhecimentos objetivos sobre os indivíduos e os grupos (ROSE, 2011, p.165-166).

Assim, a associação entre psicologia e democracia nesse período esteve ligada a uma preocupação em substituir, no interior de diversas organizações, o exercício da autoridade arbitrária pelo governo democrático, que não se impusesse sobre as liberdades individuais, mas se baseasse em conhecimentos objetivos sobre os governados. Nessa perspectiva, "para a psicologia social, assim como para a filosofia política, a natureza social do homem deve ser conhecida, se o que se pretende é governá-lo de maneira apropriada" (ROSE, 2011, p. 167). Seguindo Foucault, o autor entende o governo não apenas como o poder exercido pelo Estado, mas o poder num sentido muito mais amplo, que abrange todas as situações nas quais alguém investido de autoridade busca conduzir a ação ou o comportamento de um indivíduo ou de um grupo, tendo em vista um determinado objetivo: aumentar a produção industrial; melhorar o ensino; evitar doenças etc. Nesse sentido, o governo depende do conhecimento. Os conhecimentos são necessários para as autoridades de muitas maneiras: permitem isolar um domínio da realidade que pode então ser visto, descrito em suas características e processos e 
avaliado, de modo que os conhecimentos não apenas representam a realidade, mas participam de sua produção. O próprio indivíduo, como "uma entidade dotada de níveis relativamente fixos de inteligência, personalidade, entre outros, que variam dentro da população de acordo com a curva traçada por uma distribuição normal”, pode ser considerado uma produção da ciência psicológica. (ROSE, 2011, p.168).

Para Rose, “A constituição psicológica do indivíduo e do grupo tornaria possível uma reconciliação entre as doutrinas da liberdade e as exigências de regulamentação através de um conhecimento racional e de uma expertise neutra" (2011, p. 169). Para tanto, um aspecto fundamental da psicologia é constituído por suas técnicas de inscrição das características individuais na forma de gráficos, tabelas e números, os quais permitem a realização de comparações, o estabelecimento de normas e a realização de cálculos com base nos quais se podem tomar decisões bem fundamentadas no interior das instituições. Os testes psicológicos, por exemplo, tornaram-se um recurso valioso para a administração das individualidades ou, nos termos dos próprios psicólogos da primeira metade do século XX, para permitir pôr o homem certo no lugar certo.

O problema que se apresenta para as democracias liberais é que, embora o governo valorize "a saúde, a inteligência, o ajustamento e a virtude dos seus cidadãos como valores vitais para o sucesso da nação" (ROSE, 2011, p. 170), o alcance de sua ação política direta sobre os cidadãos é limitado, pois não se considera possível e nem aceitável que os governantes instruam e supervisionem todas as suas condutas. Deve-se, portanto, criar formas indiretas de conciliar os objetivos do governo e os desejos e aspirações dos cidadãos, não através da imposição da lei e da vigilância policial, mas por meio de estratégias de persuasão, que respeitem as liberdades individuais. O autor argumenta que as teorias, vocabulários, especialistas e técnicas da psicologia tiveram um papel fundamental nas tentativas de promover o alinhamento entre os propósitos dos governos e os dos indivíduos. E foi principalmente no interior de organizações tais como os escritórios, as fábricas, os hospitais e as escolas, cada qual com seus objetivos de governo específicos, que a psicologia se estabeleceu, "reivindicando um conhecimento racional da administração do fator humano em todos os campos da vida organizacional" (ROSE, 2011, p. 171).

Ao adentrar a escola, a psicologia procurou contribuir não apenas para melhorar a eficiência do ensino, mas também para formar nos indivíduos as virtudes consideradas necessárias à sua participação em uma sociedade democrática. Como se verá a seguir, nos 
discursos educacionais que alcançaram maior repercussão a partir da década de 1930, as relações entre Escola Nova, psicologia e democracia se estabeleceram em torno da convicção de que a reorganização dos sistemas de ensino e das práticas escolares deveria fundamentar-se na ciência psicológica. Nesses discursos, alguns enunciados são recorrentes. Um deles aparecia associado à defesa da escola única no Manifesto dos Pioneiros (1932) e estabelecia que as oportunidades educacionais devem ser as mesmas para todos os indivíduos, independentemente do grupo social a que pertencem, de modo a favorecer uma "hierarquia democrática" pela "hierarquia das capacidades" (1932). Outro defendia a organização democrática da vida escolar, por meio do incentivo à autonomia e à cooperação entre os alunos e da revisão dos currículos, de modo que os interesses das crianças se sobrepusessem à lógica do adulto na seleção dos conteúdos. Outro ainda associava virtude democrática e autoconhecimento como objetivos a serem perseguidos pela escola, com a contribuição da psicologia. Afirmava que a formação de atitudes democráticas depende da capacidade de identificar as próprias aptidões individuais e da disposição de aprimorá-las e exercitá-las em prol da coletividade. Em comum, esses enunciados estabeleciam uma correspondência entre desenvolvimento individual e desenvolvimento social, por meio da associação entre educação e psicologia. Simultaneamente, associavam psicologia, verdade e governo dos alunos.

\subsection{Educação, psicologia e democracia nos discursos dos anos 1930 e 1940 no Brasil}

O livro Introdução ao Estudo da Escola Nova, de Lourenço Filho, foi publicado pela primeira vez em 1930 e o Manifesto dos Pioneiros da Educação Nova, redigido por Fernando de Azevedo, no ano de 1932. No que diz respeito às relações entre psicologia, educação e democracia, esses dois textos podem ser lidos como pertencentes ao mesmo discurso. Vinculam-se ao movimento internacional pela renovação dos métodos de ensino que, embora tenha se iniciado no período anterior à Primeira Guerra Mundial, ganhou um novo impulso no pós-guerra, pois, de acordo com Lourenço Filho, “a conflagração mundial veio impor aos educadores a revisão dos fins tentados pela escola pública" tendo em vista a formação de "uma humanidade melhor" (1930, p. 13, p. 18). No plano nacional, esse discurso resulta de um conjunto de iniciativas levadas a efeito na década de 1920, quando foram empreendidas reformas do ensino em diversos estados brasileiros (São Paulo, Ceará, Bahia, Distrito Federal, Pernambuco, Minas Gerais e Paraná), as quais concorreram para a reorganização das escolas e 
seus currículos, a profissionalização do trabalho dos professores e a publicação de livros e revistas especializadas em questões de ensino (Nagle, 1976; Azanha, 1993).

Os dois textos defendiam a renovação dos fins e dos meios da educação. As transformações sociais provocadas pelo avanço das ciências e da tecnologia justificavam a atualização dos objetivos da escola. E a modificação dos métodos se impunha em função do desenvolvimento dos conhecimentos científicos sobre o homem, especialmente da psicologia, cujas descobertas recentes invalidavam as práticas escolares tradicionais.

Introdução ao Estudo da Escola Nova reunia um conjunto de lições proferidas por Lourenço Filho no Instituto de Educação com o objetivo de oferecer uma "simples introdução" ao tema, um "plano de topografia geral" do movimento renovador. Em sua apresentação da Escola Nova, elegia a obra Education for a Changing Civilisation, de Killpatrick, como a melhor reflexão sobre a dimensão moral do movimento e o livro Democracy and Education, de Dewey, como a melhor expressão de seus fundamentos políticos e sociais. Acrescentava que outro aspecto central da proposta era o recurso à psicologia dos testes para a "verificação objetiva dos elementos da educação e de cada passo do aprendizado" (LOURENÇO FILHO, 1930, p. 57).

O Manifesto dos Pioneiros da Educação Nova era dirigido ao povo e ao governo. Como bem observou Diana Vidal, "vinha a público no âmago das disputas pela condução das políticas do recém-criado Ministério da Educação e Saúde no Brasil (1930)” (2013, p.579). Tratava-se, fundamentalmente, da disputa entre educadores católicos e os autointitulados pioneiros, que defendiam a escola pública, laica, gratuita, obrigatória e comum para ambos os sexos. A "carta monumento", como foi designado o Manifesto por Libânia Xavier, foi assinada por 25 educadores e intelectuais brasileiros renomados na época, dentre os quais o próprio Lourenço Filho, e apresentava um caráter simultaneamente diagnóstico e programático para a educação nacional. Constitui um marco no discurso educacional brasileiro, ao expressar simultaneamente as expectativas depositadas pelos intelectuais da época na nova ordem política e na renovação do sistema educacional como recurso para o desenvolvimento do país e suas preocupações relativas ao funcionamento das escolas naquele período. Segundo a autora,

Para além das disputas no campo educacional, é preciso recordar - e isso nem sempre emerge nos debates que fazemos sobre o Manifesto - que, em 1930, a instalação de uma Nova República havia sido cantada com otimismo pela imprensa paulista, capitaneada por Julio de Mesquita Filho, como já dissemos, signatário do Manifesto e proprietário do jornal $O$ Estado de S. Paulo. A revolução significava para os novos 
liberais, aglutinados em torno do Partido Democrático, exorcismo do passado associado ao poder oligárquico, à fraude, à imoralidade, à força, à tirania, ao atraso e à mentalidade bacharelesca - e um momento de inflexão para a mentalidade moderna, caracterizada pelo saber científico, pelo progresso e pela ordem (VIDAL, 2013, p. $583)$.

À esperança seguiu-se, contudo, a insatisfação paulista com os rumos do Governo Vargas pós 1930 e o adiamento da nova constituição, que levou à designada Revolução de 1932, ocorrida quatro meses após divulgação do Manifesto. Na introdução do documento, Fernando de Azevedo, então professor de sociologia no Curso de Aperfeiçoamento do Instituto Pedagógico de São Paulo, referia-se aos desafios que se apresentavam para a cultura de seu tempo em face da aceleração das mudanças sociais, do progresso científico e da tecnologia. Observava que a mentalidade do homem, seu modo de vida e suas relações pareciam não acompanhar as mudanças em curso. Entendia que a situação no Brasil ainda era agravada, em razão de suas peculiaridades - heterogeneidade racial, indisciplina do povo, ausência de um sistema educacional universitário - que faziam do Brasil um ambiente pouco propício ao desenvolvimento da ciência, embora favorável ao florescimento das artes, aí incluída a literatura.

Azevedo enfatizava a importância da ciência na determinação das transformações sociais que se verificavam, inclusive no domínio da política. Em suas palavras, vivia-se "numa época em que se acentua por toda a parte a intervenção da ciência na direção dos negócios públicos, entregues até então ao instinto dos povos e ao capricho dos governos" (Manifesto, 1932/ 2010, p. 17). Na mesma direção, Lourenço Filho afirmava que "A ciência fulmina de ridículo ao reformador que se proponha ideias fantásticas ou pouco seguras... Exigir-se-á, por isso mesmo, que os políticos se tenham por avisados ou menos ignorantes, no imaginar reformas sociais" (1930, p. 15). Nos dois textos a defesa da renovação da escola fundamentavase no conhecimento da realidade brasileira e na ciência psicológica.

No texto de introdução ao Manifesto enunciava-se o seu propósito em termos da importância de se promover a adequação dos sistemas escolares às transformações associadas à aceleração dos processos de industrialização e urbanização e às diferentes necessidades dos grupos sociais. Aparece aí a primeira referência do texto ao ideal democrático, em contraposição aos interesses da chamada "classe dirigente":

Ora, não podia permanecer inalterável um aparelho educacional a cuja base residia uma velha concepção da vida, na sua rigidez clássica, numa época em que a indústria 
mecânica, aumentando a intensidade, transformou as maneiras de produção e as condições de trabalho, e, criando esse fenômeno novo da urbanização precipitada da sociedade, acelerou as modificações nas condições e nas normas da vida social a que correspondem variações nas maneiras de pensar e de sentir e nos sistemas de ideais e de conceitos.

Era preciso, pois, examinar os problemas de educação do ponto de vista não de uma estética social (que não existe senão por abstração), mas de uma sociedade em movimento, não dos interesses da classe dirigente, mas dos interesses gerais (de todos), para poder abraçar, pela escola, que é uma instituição social, um horizonte cada vez mais largo, e atender, nos sistemas escolares, à variedade das necessidades dos grupos sociais (1932, p. 26).

O texto do Manifesto propriamente dito inicia-se pela constatação da "inorganização" do sistema educacional, devida à dispersão das iniciativas e à falta de definição e clareza quanto aos fins e aos meios da educação. Constatava-se a necessidade de promover a renovação da escola para acompanhar o progresso científico e técnico da civilização e defendia-se a reorganização do sistema de ensino e a atualização das práticas escolares em bases científicas. No tópico "finalidades da educação", encontra-se a primeira referência direta à democracia nesse texto:

\footnotetext{
A educação nova, alargando sua finalidade para além dos limites das classes, assume, com uma feição mais humana, sua verdadeira função social, preparando-se para formar a 'hierarquia democrática' pela 'hierarquia das capacidades', recrutadas em todos os grupos sociais a que se abrem as mesmas oportunidades de educação. Ela tem, por objeto, organizar e desenvolver os meios de ação durável, com o fim de 'dirigir o desenvolvimento natural e integral do ser humano em cada uma das etapas de seu crescimento, de acordo com uma certa concepção do mundo (1932, p. 40).
}

A educação democrática dizia respeito, portanto, à criação de oportunidades iguais de escolarização e à criação de uma correspondência entre a "hierarquia democrática" e a “hierarquia das capacidades”. Manifestava-se aí a crença liberal de que a universalização do ensino por si só seria capaz de garantir a igualdade de oportunidades e a democracia, desconsiderando-se o contexto de profundas desigualdades políticas e econômicas vividas no Brasil, que tornava virtualmente impossível às crianças mais pobres alcançar o mesmo desempenho escolar das crianças favorecidas. Dada a precariedade e a dureza das condições vividas pelos ex-escravos e seus descendentes e demais trabalhadores, e o preconceito racial e social que pesava contra os seus modos de vida; os conhecimentos, a linguagem e as atitudes de suas crianças só poderiam ser, como de fato foram, sistematicamente desqualificados pelos educadores e psicólogos encarregados de avaliá-las. Contudo, no discurso do Manifesto tais aspectos não foram levados em conta e era assim que se conectavam o governo democrático e 
a psicologia, disciplina encarregada de identificar, medir e hierarquizar as aptidões, percebidas como naturais.

Nos termos do Manifesto, a educação não deveria atender aos interesses de classe, mas aos interesses do indivíduo. Não se tinha em vista, contudo, o indivíduo em "sua autonomia isolada e estéril", mas o indivíduo socializado por meio da escola e do trabalho. Defendia-se a "escola socializada" para promover as virtudes da disciplina, da solidariedade e da cooperação por meio do trabalho. Buscava-se desenvolver o pleno potencial da natureza humana em cada indivíduo, mas não se tratava de defender o individualismo. Ao contrário, pretendia-se promover a "solidariedade social e a cooperação". A "escola socializada" tinha como propósito favorecer a vivência das "virtudes e verdades morais que contribuem para harmonizar os interesses individuais e os interesses coletivos” (p. 42). No livro Introdução ao Estudo da Escola Nova, o mesmo tema está presente e aparece associado à hierarquia, mas também ao ideal da paz e à psicologia do aluno, como segue:

\begin{abstract}
A crítica social dos fins da escola pede o trabalho em comunidade, visando especialmente a formação, visando especialmente a formação do sentimento de cooperação, a solidariedade social, a disciplina bem compreendida dos que comandam e dos que são comandados. Para os educadores mais avançados, o trabalho assim organizado deve visar mais: o ideal da paz pela escola. A crítica psicológica do trabalho escolar tradicional demonstra que essa transformação não é só necessária para a consecução de tão elevados desígnios, mas para a própria normalidade do trabalho do espírito. Para a psicologia de hoje, como vimos, toda a evolução psicológica (formação lógica, formação sentimental) é efeito do comportamento socializado (LOURENÇO FILHO, 1930, p. 56).
\end{abstract}

A educação era defendida como um "direito biológico" de cada ser humano e uma responsabilidade do Estado, que tinha o dever de garantir o acesso de todos à escola comum, independentemente de sua condição econômica. Também derivavam desse direito biológico, que deveria sobrepor-se aos interesses de classe, grupos ou crenças particulares, os princípios de laicidade, obrigatoriedade e co-educação dos sexos, pois a separação dos indivíduos na escola só se justificava em função de suas “aptidões psicológicas e profissionais". Nos termos do Manifesto,

De fato, se a educação se propõe, antes de tudo, a desenvolver ao máximo a capacidade vital do ser humano, deve ser considerada 'uma só' a função educacional, cujos diferentes graus estão destinados a servir às diferentes fases de seu crescimento, 'que são partes orgânicas de um todo que biologicamente deve ser levado à sua completa formação'. Nenhum outro princípio poderia oferecer ao panorama das instituições escolares perspectivas mais largas, mais salutares e mais fecundas em 
consequências do que esse que decorre logicamente da finalidade biológica da educação (1932, p.46)

A escola socializada almejada pelo Manifesto apresentava-se como Escola Nova, em contraposição à escola tradicional, que era acusada de atender aos interesses de classe da burguesia e de separar o aluno da sociedade, encerrando-o em um mundo à parte, artificial, intelectualista e verbalista. Ao contrário, a escola que se tinha em vista era integrada à vida da comunidade e suas práticas fundamentavam-se no "estudo científico e experimental da educação", para promover a verdadeira educação funcional. Respeitava o desenvolvimento e os interesses da criança, por meio da oferta de um "meio vivo e natural", "favorável ao intercâmbio de reações e experiências" (p. 49). O livro Introdução ao Estudo da Escola Nova, já em seu prefácio apresentava-a em seu contraste com a escola tradicional e justificava a necessidade da renovação do ensino recorrendo à psicologia das aptidões naturais. Para isso, citava o próprio Fernando de Azevedo, autor do Manifesto:

\begin{abstract}
A Escola Nova, em que a criança foi restituída à alegria de viver, passando da imobilidade e do silêncio, para a atividade útil; do trabalho forçado e fastidioso para o trabalho praticado com prazer e interesse; a escola que ama a personalidade da criança... ama também a personalidade do professor, e, compreendendo que é necessário permitir à cada mentalidade desenvolver-se segundo suas leis e tendências próprias e realizar integralmente seu tipo, rejeita os professores vasados num molde único, em que se substituiu, por uma personalidade-padrão, artificial e armada, a individualidade de cada um, na variedade infinita de seus dons e recursos pessoais (FERNANDO DE AZEVEDO apud LOURENÇO FILHO, 1930, p. 8-9).
\end{abstract}

Segundo o texto do Manifesto, para promover o máximo desenvolvimento das aptidões naturais de todos os indivíduos, a escola única abolia a separação do ensino em dois ramos distintos, o primário e profissional oferecido ao povo e o secundário e superior, destinado à elite. Deveria criar-se, em vez disso, um sistema unificado, em que a educação profissional e o ensino intelectual secundário estivessem no mesmo nível. Também aí, o que se buscava era a correspondência entre os níveis de ensino e "o desenvolvimento natural do ser humano", assim, a partir do ensino secundário, o destino educacional do adolescente deveria ser traçado em função das "aptidões que a observação psicológica registra nos adolescentes e que 'representam as únicas forças capazes de arrastar o espírito dos jovens à cultura superior'” e, simultaneamente, "à variedade de formas de atividade social" (p. 55).

Há no Manifesto uma parte curiosamente intitulada "o problema dos melhores" em que se defendia simultaneamente a educação das massas populares e a seleção dos melhores 
para compor "o vértice de uma pirâmide de base imensa". Expressava-se a convicção de que era preciso tornar a elite "inteiramente aberta" às capacidades novas e ao mesmo tempo fechada aos indivíduos que não desempenhassem a contento a função social que lhes fora designada (p. 58). Mais uma vez retornava o princípio da seleção meritocrática pelo critério bio-psicológico das aptidões naturais, em vez da origem socioeconômica.

Os temas da adequação das práticas educativas ao desenvolvimento da criança; da substituição do ensino baseado na memorização de conteúdos pelo aprendizado resultante do trabalho colaborativo realizado pelos alunos; da identificação dos talentos individuais e de sua orientação para as atividades sociais condizentes por meio do recurso à psicologia também estão presentes nos dois artigos sobre psicologia, educação e democracia escritos em meados da década de 1940 pela psicóloga Helena Antipoff: "Como pode a escola contribuir para a formação de atitudes democráticas?" (1944) e "Dos perfis caracterológicos como elemento de educação democrática”(1945).

Nascida na Rússia em 1892, Helena Antipoff fez o Curso Normal em São Petersburgo e em seguida foi estudar em Paris, onde passou a se interessar pela Psicologia. Fez estágio no Laboratório Binet-Simon e familiarizou-se com os testes para a medida da inteligência. Depois disso, foi convidada por Claparède para ir à Suíça e integrou, entre 1912 e 1916, a primeira turma do Instituto Jean Jacques Rousseau, que lhe concedeu o diploma de psicóloga, com especialização em Psicologia Educacional. Voltou à Rússia no contexto da Primeira Guerra Mundial e da Revolução de Outubro de 1917 e trabalhou na Estação Médico-Pedagógica de Petrogrado e de Viatka, onde era responsável pelo diagnóstico psicológico e pelo planejamento da reeducação de crianças separadas de suas famílias nos conflitos militares. Atuou ainda como pesquisadora no Laboratório de Psicologia Experimental de Petrogrado, buscando identificar os efeitos da guerra no desenvolvimento infantil (CAMPOS; LOURENÇO, 2001, p. 53-54). A psicóloga observou que as mesmas crianças que obtinham resultados muito baixos nos testes de inteligência, mostravam-se surpreendentemente hábeis para enfrentar as condições adversas em que viviam no contexto da Revolução e passou a questionar a concepção de que a inteligência medida pelos testes de Binet fosse inata. Em um artigo escrito em 1931 referia-se a essas crianças como "um grupo considerável de indivíduos, menores, sem família, sem domicílio, sem ocupação determinada, vivendo ao léu, de esmola ou de rapina, passando a noite ao abrigo duma casa em ruína, de uma ponte, de um esconderijo qualquer...” e ponderava que 


\begin{abstract}
À margem da família, da escola e da sociedade com suas leis e suas regras, essas crianças se formavam, em uma palavra, à margem da vida civilizada. Não sendo destituídas de inteligência natural, não possuíam precisamente essa inteligência que se tributa e se disciplina ao contato do exemplo no seio do regime regrado e das exigências impostas pela vida convencional da família ou da escola, essa inteligência civilizada, que perscrutamos por meio dos nossos testes chamados de inteligência geral (ANTIPOFF, 1931, p. 86).
\end{abstract}

A convite de Francisco Campos, que realizou a reforma do ensino em Minas Gerais, a psicóloga veio para o Brasil em 1929 para lecionar psicologia na Escola de Aperfeiçoamento para professores de Belo Horizonte, a primeira instituição de ensino superior para a formação de professores no Brasil. Helena Antipoff encarregou-se do ensino de psicologia, da direção do laboratório destinado às investigações na área e da assessoria às escolas para aplicação de testes de inteligência, tendo em vista a organização das classes homogêneas e das classes especiais para os alunos avaliados como deficientes (CAMPOS; LOURENÇO; ANTONINI, 2002). Na década de 1940, no período do Estado Novo, a renovação do seu contrato de trabalho foi recusada pelo governo de Minas Gerais e a psicóloga transferiu-se para o Rio de Janeiro em busca de uma alternativa de atuação profissional. Atuou então na implantação do Departamento Nacional da Criança junto ao Ministério da Saúde e "engajou-se na luta pela redemocratização do país" (CAMPOS et al., 2002, p. 26). Os textos examinados a seguir foram escritos nesse período.

No artigo "Como pode a escola contribuir para a formação de atitudes democráticas?" (1944), a autora observava que a escola pública consistia em um ponto de encontro privilegiado de crianças de diferentes grupos sociais, mas apenas a oportunidade desse encontro não garantia a formação de atitudes democráticas. Entre todos os aspectos do ideal democrático, destacava a lealdade, que correspondia ao amor à verdade, como "virtude a praticar" e a cooperação, como "regime de trabalho a realizar". Para ela, a escola da época falhava em insuflar na criança o respeito à lealdade, ao privilegiar a transmissão verbal de conteúdos distanciados da realidade, numa fase de desenvolvimento em que a criança manifestava interesse pelo concreto. O resultado era que as crianças simplesmente memorizavam, repetiam um discurso esvaziado de significado e de compreensão da realidade. Para exemplificar o problema, a autora referia-se a uma análise de redações de alunos de diferentes idades sobre o tema "As minhas mãos", a qual evidenciava que os alunos menores reproduziam um discurso decorado, enquanto os mais velhos definiam as mãos apenas em termos de suas finalidades, o que sugeria uma compreensão egocêntrica da realidade, típica dos primeiros estágios do desenvolvimento e era indicativo do seu atraso intelectual. 
Outro modo de investigar o problema do "amor à verdade" consistia em examinar como a escola lidava com a mentira na criança, procurava disciplinar a imaginação e levar o aluno a distinguir a realidade da fantasia. Em uma experiência relatada pela autora, pedia-se às crianças do quarto ano primário que relatassem o que ocorrera na sala de aula na ausência da professora, durante um período de 15 minutos. Por um lado, constatara-se que as crianças contavam a verdade. Por outro lado, a experiência revelara que, sem a presença da professora, a classe transformara-se em 'brinquedo anárquico'. Essa observação levava ao tema da cooperação. Era preciso que as crianças aprendessem a agir com responsabilidade e liberdade, como costumavam fazer nos recreios, quando se mostravam capazes de se organizar em torno de um líder e obedeciam às regras estabelecidas para as brincadeiras. A autora se perguntava por que em sala de aula esse modo de organização não funcionava e concluía dizendo que poderia vir a funcionar, desde que a professora concedesse aos alunos oportunidades de se organizarem livremente para a realização das tarefas e deixasse "sobre os ombros infantis uma parte da sua carga de responsabilidade, acostumando-os assim à prática da autonomia e da cooperação" (1944, p. 236).

No outro artigo, "Dos perfis caracterológicos como elemento de educação democrática", Helena Antipoff observava que uma condição importante para que os indivíduos pudessem contribuir para a coletividade de que participavam era o autoconhecimento. Assim como no texto anterior, expressava a convicção de que a escola devia ensinar os alunos a ver as coisas do mundo físico e social com objetividade, inclusive aos outros e, o que era ainda mais difícil, a si próprios. Afirmava que o ensino da psicologia, em especial a observação do comportamento em situações reais, desde os últimos anos da escola primária e com mais ênfase na Escola Normal, poderia oferecer uma contribuição importante na formação do autoconhecimento do aluno.

A autora fazia referência a um exercício prático realizado com suas alunas-professoras na Escola de Aperfeiçoamento de Belo Horizonte. A partir de critérios pré-definidos, as professorandas elaboravam os "perfis caracterológicos" de suas colegas e de si mesmas. O propósito da atividade era avaliar traços da personalidade e favorecer a comparação entre o julgamento próprio e a média do julgamento realizado pelas colegas de classe. A avaliação se fazia a partir de 18 critérios, que eram os seguintes: capacidade intelectual, cultura, iniciativa, confiança em si, poder de organização, pontualidade, capacidade para o trabalho, devotamento ao trabalho, interesse pelo progresso, cooperação, sociabilidade, tato, autocontrole, lealdade, 
resistência física, emotividade, confiança nos outros e constância nos empreendimentos. No exame dos resultados, a autora tecia considerações sobre a importância, para um líder, da objetividade na autopercepção e no julgamento dos outros. Em suas conclusões, voltava a afirmar que o treino da observação objetiva de si e dos outros contribuía para a formação das atitudes democráticas. Acrescentava que o estudo das personalidades no interior de um grupo, quando realizado de modo sereno e objetivo, contribuía para a superação da atitude de desconfiança mútua, geradora de conflitos e vivida como agressão. Por isso mesmo, defendia a criação de uma atmosfera de objetividade e confiança nas escolas e nas salas de aula. Para ela, o estudo objetivo e sereno das personalidades tornava possível identificar e compensar problemas como o excesso ou a falta de autoconfiança, bem como identificar as atitudes “exaltadas", tidas como perigosas e antidemocráticas.

Ao concluir o texto, a autora afirmava que era preciso exercitar as atitudes democráticas na escola para favorecer um "bom regime democrático na sociedade adulta". Para ela, a formação das atitudes democráticas dependia tanto da capacidade de reconhecer os próprios atributos e da disposição de colocá-los a serviço da coletividade quanto da aptidão para reconhecer nos outros os atributos necessários à boa liderança. Em suas palavras,

\footnotetext{
A democracia, psicologicamente falando, é a atmosfera que, na vida de uma coletividade organizada, permite a cada um realizar o máximo de suas capacidades em benefício de todos. É, sem dúvida nenhuma, problema psicológico, que se resolverá com maior possibilidade de êxito, quando, nas escolas de todos os graus, for considerada a formação das atitudes das novas gerações; quando as escolas, desde o jardim de infância até a universidade, compreenderem que a democracia é regime de governo que se realizará com possível êxito; quando a coletividade estiver apta a discriminar nos seus membros as qualidades necessárias aos chefes e dirigentes e praticar as virtudes do regime de responsabilidade e de lealdade autêntica (ANTIPOFF, 1945, p. 236).
}

Nesses dois textos de Helena Antipoff, as relações entre psicologia, educação e democracia se estabeleciam em torno dos princípios da verdade e da cooperação. Era preciso aprender na escola a ver as coisas com objetividade, em especial tornar-se capaz de reconhecer as aptidões próprias e as alheias e de identificar as qualidades de um líder. Também era preciso aprender a trabalhar em regime de cooperação, tornar-se capaz de agir de maneira autônoma e responsável, de exercer o autogoverno em liberdade e decidir-se espontaneamente a pôr as próprias capacidades a serviço do bem comum. A psicologia era necessária à educação e à democracia de duas maneiras fundamentais. Orientava a adequação das práticas escolares às etapas de desenvolvimento infantil, dispensando a imposição da autoridade arbitrária do 
professor. E permitia identificar as aptidões naturais, favorecendo o conhecimento dos outros e o autoconhecimento, indispensáveis à adequação do desenvolvimento individual ao progresso social.

Nos discursos escolanovistas examinados anteriormente, a psicologia educacional aparecia como fundamento científico da Escola Nova, a escola moderna e democrática, que associava o desenvolvimento individual ao desenvolvimento social. Era uma ciência nova, derivada da filosofia e situada entre a sociologia e a biologia, que começava a esclarecer os processos de desenvolvimento da criança e a identificar e mensurar as capacidades individuais. Não cabia à psicologia determinar os fins da escola, mas seus saberes eram imprescindíveis para orientar os professores sobre como adaptar os métodos de ensino às necessidades e às possibilidades dos alunos para atingir suas finalidades. Seu estudo permitia dispensar a imposição de um poder arbitrário em favor de uma autoridade legítima, porque exercida em nome da promoção do desenvolvimento da criança e do respeito às individualidades. De acordo com Lourenço Filho, "Em vez da autoridade externa, a reunião de condições que permitam desenvolver-se, em cada indivíduo, a autoridade interna: toda educação deve ser uma autoeducação" (1930, p. 69).

Se o que se desejava era a formação de indivíduos autônomos e cooperativos, era preciso encorajar as crianças a investigarem por si mesmas o que despertava o seu interesse, habituá-las desde cedo a assumir a responsabilidade por seus comportamentos e a trabalhar em regime de colaboração com os colegas. Se o que se pretendia era preparar cidadãos capazes de tomar decisões racionais sobre seus próprios destinos e o destino da sociedade, dispostos a pôr seus melhores talentos a serviço da coletividade, cumpria levá-los a reconhecerem em si mesmos e nos outros as aptidões individuais que faziam de alguns, líderes natos, e dos outros, liderados "naturais". A psicologia era então a ciência da escola única para todos, destinada a criar a almejada correspondência entre a "hierarquia das capacidades" e a "hierarquia democrática”. 
Pode-se, enfim, esboçar uma resposta à questão inicialmente formulada, sobre a distância que nos separa desses discursos pertencentes ao movimento escolanovista. A partir dos desdobramentos da própria psicologia, em suas aproximações com as Ciências Sociais e a História, assim como das críticas à psicologia formuladas por diversos autores contemporâneos, dentre os quais foram mencionados Nikolas Rose e Foucault, já não se admite que as descrições dos indivíduos elaboradas pela psicologia correspondem a uma pura natureza humana ou que os indivíduos devem ser orientados para ofícios condizentes com as suas aptidões supostamente naturais. Entre outras razões, porque as aptidões socialmente reconhecidas e valorizadas na escola não são puramente naturais, mas aprendidas, e a oportunidade de seu aprendizado, dentro e fora da escola, é desigualmente distribuída na nossa sociedade, em que um verdadeiro abismo separa as condições de vida e de escolarização das crianças ricas e pobres. Mas também porque, se há algo que define uma suposta "natureza humana" é justamente a potência de desafiar a natureza - e criar arte, ciência, tecnologia inclusive desafiar-se a si própria. De modo que é preciso desafiar inicialmente o determinismo biológico, que pretende deduzir o destino dos indivíduos de sua suposta constituição natural ou, para empregar as palavras de Condorcet, fazer "da própria natureza um cúmplice do crime da desigualdade política" (apud GOULD, 2003, p.5).

O desafio, hoje, diz respeito à afirmação de que as verdades sobre quem somos e como devemos viver não estão na natureza, mas são artificialmente produzidas e estão em disputa. Consiste em sustentar, contra aqueles que pretendem submeter pessoas e grupos a uma suposta ordem natural, que a natureza não é cúmplice de quaisquer decisões políticas, o que significa que ela permanece em silêncio acerca de questões relativas a como deve ser feita a divisão social do trabalho ou como devem ser vividas as relações amorosas ou de quem (e quais) são as responsabilidades que os adultos devem assumir em relação à educação e ao cuidado das crianças. Se não há respostas definitivas para essas questões a serem encontradas na natureza ou onde quer que seja, cabe às pessoas o desafio de pensá-las no âmbito da política. Como bem observou Norbert Elias a propósito dos vínculos familiares, as relações humanas estão continuamente se transformando e a necessidade de trabalhar conscientemente sobre essas relações nunca termina (2012, p. 493). 


\section{7. "É PRECISO ADAPTAR O ENSINO ÀS CARACTERÍSTICAS DO ALUNO": ANÁLISE HISTÓRICA DE UM ENUNCIADO}

Nos discursos da psicologia dedicados às questões educacionais é recorrente o enunciado segundo o qual os professores devem adaptar o ensino às características dos alunos. A recomendação costuma ser associada ao respeito pelo aprendiz e a melhores resultados do trabalho docente. Acena aos professores com a possibilidade de exercer uma autoridade simultaneamente legítima e eficaz, porque fundamentada no conhecimento dos próprios sujeitos sobre os quais se exerce, suas motivações e possibilidades. Para promover o desejável ajuste entre a atuação docente e as necessidades daqueles que são os seus alvos, dessa orientação segue-se uma outra: os educadores devem adquirir conhecimentos científicos sobre os educandos. Sendo a psicologia a disciplina que tradicionalmente buscou criar meios de tornar visíveis, mensuráveis e administráveis as capacidades individuais invisíveis na superfície do corpo, justifica-se desse modo a importância do seu estudo na formação dos professores.

A psicologia formulou procedimentos para a quantificação das inteligências e parâmetros para a avaliação do desenvolvimento mental dos indivíduos. Os dados obtidos dessas maneiras permitem distribuir os alunos em diferentes classes, identificar aqueles que, por suas dificuldades ou comportamento atípico, demandam uma atenção especial, um programa de atividades adaptado aos seus casos particulares ou outras formas de tratamento. Em suma, a psicologia promete auxílio aos professores para compreender o que se passa com seus alunos e para tomar decisões informadas em relação a eles. Como observou Nikolas Rose,

\footnotetext{
Ao pretender dar uma sustentação à autoridade por meio de um regime intelectual e prático coerente, a Psicologia oferece tanto uma fundamentação na verdade como algumas fórmulas de eficácia. Mas, além disso, e talvez isto seja o crucial, a Psicologia, ao alegar modular o poder por meio de um conhecimento da subjetividade, pode proporcionar à autoridade social uma base que não é somente técnica e científica, mas 'ética' (ROSE, 2011, p. 124).
}

A autoridade ou o governo fundamentado no conhecimento das subjetividades são reconhecidos como legítimos, pois se exercem em nome da verdade e do respeito pela natureza dos governados. Pretendem orientá-los em direção às suas próprias necessidades, capacidades 
e interesses. Frequentemente, os conhecimentos verdadeiros sobre os indivíduos, que permitem desvendá-los e administrá-los em sua diversidade, são produzidos por procedimentos de cálculo. E, desde que se criaram as técnicas de mensuração das capacidades humanas, a individualidade deixou de ser apenas da ordem do singular e virou objeto de quantificação, mapeamento, previsão e administração. Os testes psicológicos passaram a cumprir de maneira exemplar a função de tornar as diferenças individuais calculáveis e disponíveis às autoridades encarregadas da heterogeneidade humana nas instituições disciplinares, que são a face normalizadora das sociedades liberais e democráticas.

No entanto, há décadas, o recurso aos testes de inteligência como forma de avaliar a capacidade dos indivíduos vem sendo duramente criticado. Muitos autores têm se empenhado em evidenciar o determinismo biológico subjacente aos usos mais frequentes dos testes, que tomam seus resultados como a expressão de um puro potencial hereditário e pretendem medir e hierarquizar as inteligências, como entidades reificadas (BISSERET, 1979; GOULD, 2003). Tem sido observado ainda, especialmente num país tão marcado pela desigualdade social como o Brasil, que as medidas da inteligência nas escolas serviram quase sempre para desqualificar os modos de expressão e as realizações dos alunos mais pobres, pois os submetem a provas que os avaliam a partir de critérios que tomam como normais e desejáveis a linguagem e os comportamentos típicos das crianças pertencentes aos grupos favorecidos e, portanto, só podem perceber as diferenças em relação a esse padrão como faltas ou defeitos. ${ }^{18}$

Tais questionamentos têm sido fundamentais, mas, apesar de sua divulgação, os testes psicológicos seguem sendo aplicados e novos testes continuam a ser formulados, na esperança de que as críticas às versões anteriores permitam aperfeiçoá-los para produzir resultados enfim fidedignos. Nikolas Rose pondera que uma melhor compreensão das razões pelas quais esses instrumentos adquiriram tanta legitimidade e difusão exigiria considerar a questão também pela perspectiva oposta à da crítica que enfatiza a desigualdade subjacente à sua aplicação e à interpretação de seus resultados. Para ele, a explicação do sucesso dos testes relaciona-se ao fato de que foram formulados em nome da defesa da equidade na avaliação das potencialidades humanas:

Uma das dimensões do 'poder da Psicologia' está precisamente na nova legitimidade democrática que a ciência concede aos julgamentos das diferenças humanas. A Psicologia é potente porque parece poder redirecionar tais julgamentos da esfera dos

\footnotetext{
${ }^{18}$ Entre muitas outras referências importantes, pode-se citar: PATTO (1990, 2000); MOYSÉS \& COLLARES (1997).
} 
valores, dos preconceitos e do senso comum para a esfera da verdade humana, da igualdade de padrões, das escolhas consistentemente justificáveis e dos critérios objetivos de eficácia que deveriam prevalecer em uma democracia (ROSE, 2011, p. 128).

Ao tornar o intelecto mensurável, a psicometria atendeu às demandas de autoridades encarregadas de administrar a multiplicidade humana nas instituições das sociedades liberais de democráticas. A distribuição das capacidades individuais na curva normal proporcionou fundamentação científica para a repartição dos indivíduos, de acordo com o que se identificava como sendo suas possibilidades, suas necessidades, seu valor. No âmbito educacional, as técnicas de mensuração das individualidades logo se fizeram acompanhar da perspectiva do "desenvolvimento", a qual era aparentemente mais benigna, mas, por isso mesmo, tornou-se ainda mais insidiosa. Por meio da observação do comportamento infantil em creches e clínicas, os pesquisadores estabeleceram padrões de comportamento para cada idade, alinhados num eixo temporal dividido em etapas. Esse modo de sistematização das observações tornou possível a comparação entre as capacidades de qualquer criança individual e a norma para a sua faixa etária. Diversas manifestações infantis relativas à postura, locomoção, aquisição de vocabulário, destreza manual, modos de interação com os objetos e com outras pessoas etc. passaram a ser apreciadas como indícios de seu desenvolvimento normal, adiantado ou atrasado. As escalas de desenvolvimento multiplicaram-se e tornaram-se parte do saber considerado imprescindível para os professores adaptarem o ensino às características individuais dos alunos. Por meio da sua divulgação, mães, pediatras, professores e outros profissionais encarregados dos cuidados e educação das crianças passaram a atuar como vigilantes do desenvolvimento, sempre atentos às manifestações atípicas do comportamento que pudessem sugerir a necessidade de intervenções corretivas.

No decorrer do século XX, a psicologia tornou-se uma disciplina central nos currículos de formação docente, e foi principalmente no seu estudo que os professores buscaram respostas e orientações para lidar com aqueles que não apresentavam o desempenho escolar esperado. Este capítulo examina os modos de presença do enunciado segundo o qual os professores devem ajustar o ensino às características dos seus alunos e, para tanto, precisam aprender a identificá-las. A partir do exame de manuais de psicologia educacional destinados à formação docente, publicados ao longo do século XX e nas primeiras décadas do século XXI, busca-se verificar como esse enunciado aparece, reproduz-se e se transforma, e com que outros se articula. Que continuidades e rupturas se podem observar ao longo do tempo nos discursos 
da psicologia acerca da importância de se adaptar os modos de ensinar aos modos individuais de aprender?

Tomando-se como centro da análise um enunciado específico, pretende-se verificar, no exame conjunto dos textos selecionados, os seus modos de aparição e repetição, suas variações e transformações, suas relações com as formações discursivas de que fazem parte. Tendo em vista as considerações de Foucault em A arqueologia do saber, deve-se observar, porém, que a sua concepção de enunciado supõe um modo de delimitação próprio. Embora o enunciado possa ser expresso na forma de uma frase, afirmação ou sentença, ele não equivale a essas unidades textuais (FOUCAULT, 2004, p. 138-139). Os enunciados são materialidades repetíveis, mas isso não quer dizer que se deva procurar por suas reproduções literais em fontes diversas, uma vez que um mesmo segmento de texto em superfícies distintas pode produzir diferentes enunciados, dependendo dos outros aos quais se encontra associado em cada caso. Não se busca, assim, encontrar reproduções literais, mas identificar em quantas formulações diversas, associada a que outros enunciados distintos, produzindo que efeitos de verdade e que prescrições o enunciado os professores devem adaptar o ensino às características do aluno compareceu nos discursos dos manuais de psicologia aqui considerados. Conforme Foucault (2004, p.119),

\footnotetext{
Ao invés de ser uma coisa dita de forma definitiva - e perdida no passado, como a decisão de uma batalha, uma catástrofe geológica ou a morte de um rei -, o enunciado, ao mesmo tempo que surge em sua materialidade, aparece com um status, entra em redes, se coloca em campos de utilização, se oferece a transferências e a modificações possíveis, se integra em operações e em estratégias onde sua identidade se mantém ou se apaga. Assim, o enunciado circula, serve, se esquiva, permite ou impede a realização de um desejo, é dócil ou rebelde a interesses, entra na ordem das contestações e das lutas, torna-se tema de apropriação ou de rivalidade.
}

Nos discursos da psicologia educacional disseminados nos manuais de ensino dessa disciplina, nosso enunciado-núcleo encontra-se associado a outros, derivados de estudos científicos sobre a medida e o desenvolvimento da inteligência. Tais pesquisas, realizadas pelo menos desde o século XIX, partiram da aposta na desigualdade das inteligências entre os grupos humanos e entre os indivíduos no interior de um mesmo grupo.

\subsection{Estudos psicológicos sobre a desigualdade das inteligências nos escolares}

Estamos, portanto, em presença de um movimento de extrema importância, pois que tende a nada menos do que revolucionar nossas ideias acerca dos valores humanos, e 
acerca da utilização que deles podemos fazer. Não pediremos assim, a cada um, senão o que se lhe pode pedir, mas pediremos a cada um tudo quanto possa fornecer. Não imagino, absolutamente, que os testes sejam o único instrumento que para isso convenha. Mas foram o modelo e marcaram o início. Foram o primeiro exemplo de medida direta do valor psicológico dos indivíduos. Reafirmaram a ideia da desigualdade dos homens, sobre outra base que não a de vago sentimento. Permitiram demonstrar seu papel universal, e tomaram a si medir essa desigualdade (BINET \& SIMON, 1929, p. 29).

Os indivíduos não se assemelham no referente à inteligência global; uns são mais inteligentes, outros menos (CLAPARÈDE, 1959, p.144).

Existem indivíduos bem dotados, melhor dotados que outros (PIAGET, 1978, p. 223).

Na passagem do século XIX para o século XX, em plena vigência das teorias raciais que expressavam a crença na desigualdade das inteligências entre os grupos populacionais, difundiram-se mundialmente os sistemas nacionais de ensino primário para toda a população em idade escolar. O modelo de escola que então se consagrou foi o dos grupos escolares seriados em que se praticava o ensino simultâneo. As turmas eram formadas por educandos da mesma faixa etária e aproximadamente o mesmo nível de conhecimentos. Todos deviam acompanhar simultaneamente um currículo comum sob as instruções do professor responsável pela classe, de modo a adquirir os conhecimentos designados para a sua série no mesmo intervalo de tempo. Nessas condições, tornavam-se perceptíveis as diferenças individuais entre os alunos quanto à maior ou menor rapidez para aprender. As crianças que não conseguiam aprender como as outras se tornavam alvo da preocupação dos professores e passaram a representar um problema para a administração do ensino. Ao mostrarem-se impermeáveis à instrução e à moralização escolar produziam um temor em relação ao seu próprio futuro, o de que se transformassem em pessoas sem trabalho, dependentes da ajuda social e potencialmente delinquentes (ROSE, 1999; DONZELOT, 2001).

Cabe retomar aqui o que já foi dito em capítulos anteriores sobre o modo como se procurou enfrentar esse problema. No ano de 1904, o Ministério da Educação Pública da França pediu ao pesquisador Alfred Binet (1857-1911), à época o diretor do Laboratório de Psicologia da Sorbonne, que formulasse um recurso prático para a identificação das crianças retardadas, de modo que elas pudessem ser separadas para um programa de educação especial. Binet havia se formado em Direito, mas logo enveredou pelo campo da psicofisiologia e da clínica psiquiátrica (ZAZZO, 2010, p.13). Realizou estudos sobre as diferenças individuais de inteligência recorrendo inicialmente aos antigos métodos da craniometria, por meio da comparação entre as medidas das cabeças dos melhores e piores alunos, conforme a indicação dos professores, em diversas escolas. Seus estudos, porém, não chegaram a resultados convincentes, o que levou o pesquisador a renunciar à medida dos crânios como modo de 
acessar a inteligência. Para atender à solicitação do ministério, Binet criou provas variadas que exigiam capacidades mentais consideradas importantes para a aprendizagem escolar, tais como memória, discriminação auditiva, discriminação visual, ordenação, compreensão, invenção e crítica. No início, os resultados obtidos nos testes eram apenas ordenados; em 1908, Binet passou a associar a cada teste a idade em que a maioria dos indivíduos testados se mostrava capaz de resolvê-lo. Daí em diante, a idade relacionada às tarefas mais difíceis que uma criança se mostrava capaz de realizar passou a ser considerada como a sua idade mental. Assim tornouse possível comparar a idade mental à idade cronológica do educando e determinar se ele era normal, adiantado ou retardado. Podia-se ainda estimar o tamanho de seu atraso ou adiantamento em anos ou meses. Posteriormente, o psicólogo alemão W. Stern propôs que o cálculo da idade mental fosse feito por meio da divisão da idade mental pela idade cronológica, para que se pudesse verificar a diferença relativa entre os dois valores, o que permitiria uma avaliação mais adequada da gravidade do atraso nos indivíduos considerados débeis mentais. A partir de então o resultado dos testes tornaram-se conhecidos como quociente de inteligência ou Q.I. (GOULD, 2003). Inicialmente, a escala métrica da inteligência foi concebida apenas como um meio de identificar débeis mentais, que se pretendia retirar das classes comuns para encaminhá-las a programas de educação especial. Logo a seguir, porém, novas aplicações dos testes foram imaginadas. O próprio Binet considerou que, a partir do estudo evolutivo da inteligência infantil, seria possível e desejável realizar uma avaliação dos programas escolares quanto à sua adequação às diferentes idades:

\footnotetext{
Ocupando-nos em traçar a linha da evolução da inteligência na criança, nós fomos naturalmente levados a dar uma olhada nos programas de ensino, e a constatar que alguns desses ensinos são muito precoces, ou seja, mal adaptados à receptividade mental dos jovens. Em outros termos, as relações de evolução intelectual das crianças com o programa de ensino constituem um novo problema (BINET, 2010/1907, p. 68).
}

Além disso, a possibilidade de identificar o nível de inteligência dos indivíduos a partir da aplicação de um teste que produzia um resultado numérico, portanto ordenável em uma escala hierárquica, levou à idealização de um mundo onde não apenas os deficientes mentais seriam retirados das escolas e dos postos de trabalho reservados às pessoas normais, mas ainda seria possível efetuar uma distribuição científica ou objetiva dos indivíduos pelas diferentes profissões. Bastava efetuar uma correspondência entre os ofícios disponíveis e o nível de inteligência requerido para a realização de cada um. Os criadores da escala métrica da 
inteligência chegaram a vislumbrar essa possibilidade, ao afirmarem "Parece provável, com efeito, que haja, para cada profissão, um grau mínimo de inteligência necessária” (BINET; SIMON, 1929, p. 28-29). Tal compreensão da inteligência foi disseminada em manuais de psicologia educacional publicados no Brasil nas primeiras décadas do século XX.

O tema da desigualdade das inteligências e da importância de se adequar o ensino às capacidades dos alunos também teve destaque na obra de Édouard Claparède (1873-1940), protagonista do movimento pela renovação das práticas escolares, fundadas nos dados objetivos da ciência e defensor entusiasta da escola ativa. Entre seus enunciados reproduzidos nos manuais de psicologia educacional, identifica-se o seguinte, relativo à necessidade de basear a pedagogia no conhecimento da infância: "Que a pedagogia deve fundar-se no conhecimento da criança como a horticultura no das plantas parece ser uma verdade elementar" (CLAPARÈDE, 1916 apud HAMELINE, 2010, p. 20-21). Dizia ainda:

Há que se estudar, portanto, as manifestações naturais da criança e ajustar a elas a ação educativa. Os métodos e os programas gravitando em torno da criança, e não a criança que gira ao redor de um programa imposto, sem poder contar com ele, tal é a revolução copernicana na qual o educador é convidado a adentrar.

Médico, psicólogo e educador, Claparède entendia que as diferenças individuais quantitativas de inteligência já eram levadas em conta nas avaliações escolares. Faltava considerar, porém, as diferenças qualitativas, uma vez que os indivíduos demonstravam aptidões naturais distintas para as diferentes áreas do conhecimento. Para Claparède, as aptidões específicas eram ainda mais importantes do que as diferenças de inteligência global, embora fossem desconsideradas pela escola. Por essa razão, defendia a escola sob medida, em que os talentos inatos fossem logo identificados para que cada criança pudesse ser encorajada a desenvolver ao máximo o potencial que demonstrava possuir desde o início de sua escolarização, em vez de perder tempo tentando adquirir habilidades para as quais não tinha inclinação:

(...) é preciso levar em conta as diferenças de aptidões, porque ir contra o tipo individual é ir contra a natureza. E ir contra a natureza tem duplo inconveniente: em primeiro lugar, como já vimos, não há rendimento, ou só um rendimento não proporcional ao esforço despendido. E, em seguida - é preciso insistir - repugnância. Este fenômeno da repugnância, muito descuidado pela pedagogia corrente, tem imensa importância moral e social. Importa, com efeito, que a ideia do trabalho não esteja associada à da repugnância, mas, ao contrário, à de satisfação (CLAPARÈDE, 1959, p. 149). 
A escola sob medida dedicava-se, portanto, a reforçar as diferenças individuais. A esse respeito, Nöelle Bisseret lembra que Claparède, ao formular a sua proposta pedagógica, estava interessado principalmente em contribuir para a seleção e o encaminhamento profissional dos alunos. Assim como outros psicólogos de seu tempo - Binet, Stern - entendia que era preciso pôr as aptidões naturais identificadas nos indivíduos a serviço da sociedade. E, como seus colegas, tendia a considerar como superiores os atributos próprios dos integrantes de seu próprio grupo social, enquanto classificava como inferiores as habilidades demonstradas pelos outros: "Dessa forma, a hierarquia das aptidões se constitui à imagem da hierarquia social: a inteligência geral (fator G) é o apanágio dos dirigentes; capacidades específicas e limitadas caracterizam os que executam" (BISSERET, 1979, p. 50).

Outro estudioso do tema da inteligência cuja obra tornou-se uma das principais referências no ensino da psicologia para professores em formação é Jean Piaget (1896-1980). Ele realizou sua formação inicial em Biologia, mas logo se aproximou da psicologia, ao procurar compreender o desenvolvimento da inteligência, desde as formas mais primitivas de pensamento na criança pequena, até a conquista do raciocínio lógico e do pensamento científico, que considerava as formas mais sofisticadas de exercício da inteligência. Adepto da teoria da recapitulação, são frequentes em seu trabalho as comparações entre o pensamento da criança e o dos "povos primitivos" ou das civilizações antigas. Leitor de Herbert Spencer e de Edouard Claparède, Piaget considerava que todas as ações humanas, incluindo o pensamento, eram sempre desencadeadas por uma necessidade, um interesse, uma motivação. Para ele, é a necessidade, ao levar o sujeito a agir, que promove o desenvolvimento da inteligência. No artigo "O tempo e o desenvolvimento intelectual da criança", conjecturava que as diferenças observadas entre os indivíduos podiam ser atribuídas ao fator biológico: "Existem pois adiantamentos, mas esses adiantamentos são o resultado de uma maturação biológica mais rápida? Isso é muito possível, porque existem ritmos muito diferentes no crescimento individual" (Piaget, 1978, p. 223). Por outro lado, nos casos em que se observavam diferenças significativas entre grupos de indivíduos, a desigualdade era mais provavelmente explicável pelo fator social. No mesmo texto Piaget manifestava seu entendimento de que o atraso de aproximadamente quatro anos verificado no desenvolvimento das crianças da Martinica, em comparação com as suíças e canadenses, devia-se, não a diferenças biológicas, mas à falta de estímulo do meio social. Ainda nesse artigo, Piaget enunciava a necessidade de ajustar o ensino à etapa de desenvolvimento psicológico em que se encontrava o aluno. Dizia: "do ponto de vista da ação do tempo, é precisamente esse desenvolvimento espontâneo que constitui a 
condição preliminar evidente e necessária para o desenvolvimento escolar, por exemplo" (PIAGET, 1978, p. 212).

\subsection{Psicologia, educação escolar e formação docente no Brasil}

Entre nós, as pesquisas sobre questões psicológicas foram realizadas inicialmente nas faculdades de medicina no Rio de Janeiro e na Bahia, a partir de meados do século XIX (PESSOTTI, 1975). Nas décadas iniciais do século XX, as instituições educacionais passaram a constituir espaços privilegiados para o desenvolvimento e a aplicação da psicologia. Esses trabalhos visavam principalmente à produção de conhecimentos científicos sobre os alunos, como subsídios para a organização do trabalho na escola. A aplicação de testes de inteligência destinava-se a identificar os "deficientes", que se pretendia retirar das escolas comuns e, quando possível encaminhar às raras instituições de educação especial disponíveis. Defendiase a classificação dos alunos segundo o critério da inteligência e a formação de classes homogêneas nas escolas, de modo a ser possível ajustar o ensino às capacidades individuais. $\mathrm{O}$ primeiro Laboratório de Psicologia Experimental criado no país foi instalado no Pedagogium, no Rio de Janeiro, no ano de 1906. Em 1914 criou-se na Escola Normal de São Paulo o Gabinete de Antropologia Pedagógica e Psicologia Experimental. Em Minas Gerais, a coordenação do primeiro Laboratório de Psicologia, criado na Escola de Aperfeiçoamento de Belo Horizonte para subsidiar as ações educativas coube à Helena Antipoff, psicóloga russa que chegou ao Brasil em 1929 e também se dedicou à educação dos deficientes mentais. Outras iniciativas se seguiram em diversos estados brasileiros, de maneira concomitante à inserção da psicologia nos currículos de formação docente (TAVARES, 1995; ANTUNES, 2007).

Gradativamente, a psicologia foi adquirindo maior prestígio como ciência capaz de fundamentar as práticas escolares e favorecer o ajustamento do ensino às características dos alunos. O ensino da disciplina iniciou-se em São Paulo e no Rio de Janeiro em 1912. A partir de 1928, a matéria passou oficialmente a integrar o currículo das escolas normais, assim como a pedagogia, a história da educação, a didática, a sociologia, a higiene e a puericultura (MONARCHA, 1999; ANTUNES, 2007). Nesse período inicial, a psicologia ensinada nas escolas normais não era ministrada por psicólogos, pois não havia curso superior exclusivamente dedicado à disciplina. Seus professores eram oriundos de outras faculdades, especialmente da medicina e do direito. Formados sob a influência de teorias que viam a 
miscigenação do povo brasileiro como um problema, os médicos empenhavam-se na difusão de princípios de higiene, enquanto os advogados procuravam formular leis cujo propósito era melhorar a qualidade da população.

Da década de 1920 em diante, as questões educacionais passaram a ser objeto de estudos especializados. Surgiram publicações especificamente dedicadas aos problemas do ensino, as quais passaram a difundir os preceitos da Escola Nova (Nagle, 1976). No Brasil, foram signatários do Manifesto dos Pioneiros da Educação Nova (1932) Sampaio Dória, Lourenço Filho e Noemy da Silveira Rudolfer, que se sucederam no ensino de psicologia na Escola Normal de São Paulo. O manifesto, que defendia a escola pública, laica, gratuita e obrigatória, recomendava ainda que as práticas escolares fossem fundamentadas nos conhecimentos científicos sobre a psicologia da criança. Em Introdução ao Estudo da Escola Nova, uma das principais obras de divulgação de seus princípios, Lourenço Filho afirmava:

\footnotetext{
O ensino não se pode fazer segundo o plano lógico dos conhecimentos organizados pelo adulto, mas segundo as fases de evolução natural da criança e do adolescente. Os programas não podem ser organizados a priori, nem impostos sob o pretexto de serem julgados úteis pelos adultos. E o mestre, ao invés de ser apenas o ensinante, tem de ser guia precavido, capaz de propor, a cada idade e em cada situação, as condições naturais de desenvolvimento da criança (LOURENÇO FILHO, 1942, p. 79).
}

Nas décadas de 1940 a 1960, os estudos da psicologia encontraram um espaço propício nas faculdades de filosofia que então se criavam no país. Parte importante desses trabalhos dedicava-se a compreender, a partir da perspectiva funcionalista de Dewey e Claparède, e da teoria psicogenética de Piaget, as influências do meio e da cultura na formação dos indivíduos. São desse período as primeiras iniciativas pela criação de um curso superior de psicologia no país. Annita Cabral, formada em filosofia na Universidade de São Paulo, onde mais tarde veio a lecionar psicologia, foi protagonista nesse movimento (CAMPOS ET AL., 2004, p. 178). No Rio de Janeiro, Antônio Gomes Penna, formado em filosofia pela Universidade Federal do Rio de Janeiro, tornou-se professor do Instituto de Psicologia associado à faculdade e dedicou-se a divulgar no Brasil a teoria psicogenética de Piaget:

Os profissionais que nas décadas de 1940 e 1950 estiveram envolvidos com pesquisas, ensino e publicações na área da Psicologia em diferentes cursos universitários, tornaram-se professores dos primeiros cursos de Psicologia que foram criados na época da regulamentação da profissão de psicólogo no Brasil, em 1962. A criação dos cursos universitários de Psicologia no país possibilitou o aumento tanto do acesso aos conteúdos das teorias psicológicas, como dos espaços para a sua 
discussão. Neste contexto, alguns dos temas que haviam marcado a formação da geração anterior - a Psicologia social culturalista, a Psicologia das diferenças individuais e a abordagem psicogenética - passaram a ser discutidos por profissionais e estudantes de graduação com formação e interesses específicos em Psicologia (CAMPOS ET AL., 2004, p. 183).

No período que se seguiu, sobretudo nas décadas de 1980 e 1990, intensificaram-se os estudos sobre a obra de Piaget e as pesquisas dedicadas a investigar suas aplicações e seus desdobramentos. Em 2004, ao concluir uma análise sobre o lugar da perspectiva genéticofuncional na psicologia brasileira contemporânea, Campos et al. identificavam a recente multiplicação de grupos dedicados às pesquisas nessa linha, que implicou na dispersão e diversificação dos temas investigados (CAMPOS ET AL., 2004, p. 196).

Para além da perspectiva genético-funcional, outras modalidades de análise psicológica dos problemas educacionais surgiram nos discursos especializados. Na década de 1970, as pesquisas dedicadas a pensar o fracasso escolar conduzidas no âmbito de programas de pós-graduação em psicologia e do Departamento de Pesquisas Educacionais da Fundação Carlos Chagas apropriaram-se de elementos da teoria da carência cultural, de origem norteamericana. Esses trabalhos dedicaram-se ao estudo do desenvolvimento psicológico das crianças pobres, com o objetivo de identificar suas diferenças em relação às de classe média e a propor modos de adequação do ensino às características e necessidades dos pequenos marginalizados. Afirmava-se que as crianças pobres sofriam um processo de "privação cultural", pois suas famílias eram incapazes de lhes proporcionar condições adequadas para o bom aproveitamento nos estudos e estímulos adequados. Para a superação desse problema, recomendava-se a criação de programas de educação compensatória, destinados a oferecer às crianças pobres a "estimulação" para aprender que supostamente lhes faltava em casa. (PATTO, 1990).

Nas décadas de 1980 e 1990 passaram a ganhar cada vez mais espaço no campo acadêmico as críticas ao papel desempenhado pelos psicólogos escolares e às "práticas discriminatórias e individualizantes no contexto escolar" (BARBOSA; MARINHO-ARAÚJO, 2010, p. 396), bem como à associação entre dificuldades escolares e deficiências biológicas individuais e à desconsideração dos fatores sociais e escolares associados aos problemas vividos pelos alunos nas escolas. Passou-se a questionar as demandas escolares de auxílio da psicologia para o ajustamento dos alunos às exigências da instituição por se considerar que, ao realizar esse tipo de atendimento, "o psicólogo se compromete com a reprodução das relações instituídas e funciona como legitimador da desumanização do homem, quando seu trabalho 
reproduz ou mantém a exclusão" (Guzzo et al., 2010, p. 133). Barbosa e Marinho Araújo afirmam que, no início do século XXI, tais reflexões levaram à defesa da presença do psicólogo escolar no cotidiano das instituições educativas, tendo em vista a substituição das práticas destinadas à remediação de problemas localizados no aluno por uma nova modalidade de atuação desse profissional, orientada para a compreensão das relações institucionais e intervenções nos espaços coletivos (2010, p. 398).

Paralelamente, um outro conjunto de trabalhos, ao qual se acrescenta esta análise, tem se dedicado ao exame histórico e crítico dos vários investimentos da psicologia sobre a educação escolar e seus efeitos nos discursos e práticas pedagógicas contemporâneas. Muitos desses estudos, valendo-se da perspectiva foucaultiana, evidenciaram os modos de produção discursiva e institucional de um sujeito psicológico portador de determinadas características que são tomadas como naturais, essenciais, necessárias. Analisaram ainda os processos de normalização dos comportamentos na escola, cuja contraface é a patologização de todas as manifestações consideradas não conformes às exigências estabelecidas. Alguns observaram, como consequência dos fatores precedentes, o enfraquecimento da autoridade dos professores, cada vez mais esvaziada e subordinada à dos especialistas $p s i$. Uma vez que são reconhecidos como os detentores da ciência da subjetividade, deles se passou a esperar todas as respostas relacionadas a "como funciona" o aluno e a "como ensinar"19 , daí as elevadas expectativas que se depositaram sobre a psicologia e suas aplicações educacionais ao longo do século XX.

Os manuais de psicologia que constituem as fontes deste estudo foram elaborados por professores da disciplina em escolas normais ou cursos universitários destinados à formação de professores no Rio de Janeiro, Minas Gerais, São Paulo e Ceará, entre 1900 e 2014. Dentre os autores cujos compêndios foram publicados até a década de 1930, três eram advogados, três médicos e um era formado em Filosofia. Aqueles que escreveram nas décadas de 1940 a 1960 eram, em sua maioria, oriundos da Escola Normal. Os títulos mais recentes, publicadas a partir de 1970, foram escritos por professores formados em História, Filosofia, Psicologia ou Pedagogia, às vezes em dois cursos superiores e frequentemente pós-graduados.

Os títulos dos compêndios mais antigos, publicados até a primeira metade da década de 1930, embora sejam produtos dos cursos de psicologia ministrados pelos autores em Escolas Normais, trazem apenas a palavra psicologia, sem referência explícita à educação. Os manuais

\footnotetext{
${ }^{19}$ Entre muitas outras referências, pode-se citar: Moysés \& Collares, 1997; Silva, 1998; Walkerdine, 1998; Varela, 1999; Lima, 2004; Aquino, 2009; Bautheney, 2011.
} 
publicados nos anos seguintes referem-se à matéria como psicologia educacional ou psicologia aplicada à educação. Os manuais da década de 1990 em diante tratam a matéria como psicologia “na" educação ou "da" educação.

Considerando-se os manuais mais antigos, publicados até a década de 1930, pode-se identificar a seguinte estrutura típica: introdução dedicada à apresentação da psicologia, sua história e seus métodos de investigação; um capítulo dedicado à base orgânica dos fenômenos psíquicos ou ao estudo das sensações; uma quantidade variável de capítulos para a descrição dos fenômenos psicológicos da afetividade, inteligência e vontade, incluindo-se, em alguns casos, um capítulo dedicado à linguagem e outro à criança anormal; um capítulo final para a explanação do caráter e da personalidade, entendidos como síntese dos elementos anteriores. A partir da década de 1930, surgem capítulos dedicados ao desenvolvimento, bem como à discussão sobre o modo como a hereditariedade e o meio o influenciavam. Nesse período, tornam-se mais frequentes as referências às aplicações pedagógicas dos conhecimentos psicológicos. Com João de Sousa Ferraz, em 1957, a psicologia educacional é apresentada como uma disciplina própria. O tema das diferenças individuais ganha destaque nesse compêndio, em que o enunciado segundo o qual se deve adaptar o ensino às características dos alunos aparece já no sumário: "Princípios de adaptação da educação aos vários níveis do comportamento inteligente". Com Noemy da Silveira Rudolfer, surge pela primeira vez um manual que se estrutura não por meio da exposição dos elementos ou fenômenos psicológicos, mas a partir da história geral da psicologia educacional. Na década de 1960, alcançou grande sucesso o manual de Afro do Amaral Fontoura, obra em dois volumes, o primeiro dos quais era dedicado à exposição do desenvolvimento infantil nas diferentes etapas: primeira infância, segunda infância, terceira infância e adolescência, organização que se tornaria recorrente em manuais posteriores. Nos anos de 1980 observa-se uma diversificação maior dos conteúdos. Enquanto alguns manuais dão continuidade à perspectiva tradicional no tratamento da disciplina, outros apresentam novos modos de tratar a matéria, inclusive introduzindo uma perspectiva crítica em relação aos discursos dominantes na área, ao questionar, por exemplo, o caráter inato das aptidões (Davis; Oliveria, 1994; Goulart, 2014). O livro Repensando a psicologia educacional, de May Guimarães Ferreira efetua uma crítica aos discursos da psicologia educacional a partir da perspectiva marxista. Nesse período, surge ainda um novo modo de organizar a matéria, que se tornou recorrente e que consiste na exposição de algumas teorias psicológicas influentes no campo pedagógico, seguidas da discussão de suas implicações educacionais (Cunha, 2008; Goulart, 2014). 


\subsection{Os professores devem adaptar o ensino às características dos alunos}

No que se segue, não se busca apresentar uma análise exaustiva de todas as ocorrências desse enunciado nos manuais de psicologia. Pretende-se evidenciar aquelas que parecem particularmente representativas de sua presença desde as primeiras décadas do século $\mathrm{XX}$, quando a disciplina começou a figurar no currículo das Escolas Normais, até os dias de hoje, em que se tornou objeto de uma série de questionamentos quanto à sua relevância e legitimidade na formação dos professores.

O enunciado está ausente em Lições de pedagogia. Parte 1: Psychologia, escrito por Valentim Magalhães e publicado em 1900. Sua primeira aparição foi identificada no livro Noções de psychologia (1917), de Manoel Bomfim, no primeiro dos dois apêndices do livro, intitulado "Caracterização dos anormais escolares". Apresentava-se na forma de defesa de um regime educativo especial para os chamados anormaes escolares, com o objetivo de torná-los aptos à vida "comum e livre, como personalidades úteis e moralizadas" (1917, p. 355). Diziase: "Os anormais escolares caracterizam-se pela tríplice circunstância de serem anormaes num grau reduzido, tanto assim que podem ser educados, isto é, são relativamente curáveis, mas precisam de um regime especial" (1917, p. 355, destaques do autor). Acrescentava-se que a desejável adaptação do ensino às necessidades dos alunos anormais, por meio da instituição do regime especial dependia do estudo psicológico de suas incapacidades:

(...) é de toda importância que a anormalidade psíquica seja devidamente reconhecida e classificada desde cedo, afim de ser convenientemente atendida, porque é essa a condição essencial de cura - instituir-se em tempo um regime educativo apropriado. $\mathrm{O}$ anormal escolar, abandonado à vida comum, torna-se geralmente um tipo insocial. Os processos ordinários de instrução não chegam a dar-lhe o preparo e o desenvolvimento preciso para que ele possa tirar da inteligência os recursos que a vida exige de cada um (BOMFIM, 1917, p. 355-356).

Em um compêndio publicado na década seguinte, a adaptação do ensino às características dos alunos não se referia apenas aos anormais, mas a todos. No espírito da Escola Nova, afirmava-se a especificidade da infância e a importância de se conhecer sua psicologia para promover o seu desenvolvimento. E estabelecia-se que a direção a ser dada ao desenvolvimento era a da "adaptação ao meio social". Conhecer e respeitar a natureza infantil não significava contemplar o seu desenvolvimento espontâneo, deixando-se surpreender pelas transformações na criança ao longo do tempo. Bem longe disso, consistia em estudá-la 
cientificamente para descobrir o modo mais eficaz de promover o seu ajustamento às exigências sociais. No prefácio do Compêndio de Psychologia (1925), de Henrique Geenen, o enunciado surge como a expressão de um consenso já bem estabelecido, cuja demonstração parecia desnecessária, porque redundante:

É levar mochos a Atenas querer provar a imprescindível necessidade dos conhecimentos psicológicos para a pedagogia. Os recentíssimos e esplêndidos estudos do psychologo J. Piaget e de Stern sobre as creanças, cuja lógica é bem diferente da lógica do adulto, mostram quão criminosamente procedem os pedagogos, que por desconhecerem os dados psychologicos, atalham em vez de promover o desenvolvimento psychico das creanças para a sua adaptação ao meio social (GEENEN, 1925, p. 8).

Nas décadas de 1930 e 1940, dois compêndios registravam um mesmo enunciado, o qual se associava àquele que se está examinando, para justificá-lo. Trata-se do seguinte: "só se governa a natureza obedecendo-a". Esse havia sido referido anteriormente por Claparède que, por sua vez, reproduzia-o a partir da obra Novum Organum, de Francis Bacon (1561-1626). Bacon asseverava que o homem deveria obedecer a natureza para poder dominá-la. Claparède trazia esse enunciado para o campo da psicologia e afirmava que o professor precisava obedecer a natureza infantil para poder "fazer dela alguma coisa". Em função desse princípio geral, realizava-se a crítica de práticas educativas que desrespeitavam a natureza infantil: “O método, por conseguinte, que tortura a criança, forçando-a, por exemplo, a passar horas vendo se fixa na mente uma lição, excessiva para a sua idade, é um método contrário à natureza, um método reprovável” (MENDES, 1943, p. 29-30). Em Psicologia educacional, de Afro do Amaral Fontoura, publicado décadas mais tarde, a defesa do método intuitivo baseava-se no mesmo princípio segundo o qual era preciso respeitar a natureza infantil:

(...) a criança tem uma grande capacidade de observação, às vezes maior do que a do adulto; em compensação possui reduzida capacidade de raciocínio. Por isso, na escola, o método preferido deve ser o intuitivo, isto é, o baseado nas cousas concretas e na observação dos alunos. Seja em Linguagem, Matemática ou Geografia, o ensino deve partir sempre da observação direta da criança (FONTOURA, 1966, p. 107).

Da década de 1990, Fundamentos de psicologia educacional, de Maria Aparecida Cória-Sabini, recomendava aos professores que respeitassem as características do desenvolvimento infantil adaptando sua maneira de se comunicar ao nível dos alunos:

Essas diferentes formas de aprender devem ser consideradas pelos professores ao tentar ensinar e avaliar o desempenho de seus alunos. A comunicação com as crianças requer que o professor respeite as fantasias e instabilidades do pensamento infantil. Requer, ainda, que ele esteja disposto a falar no nível da criança (CÓRIA-SABINI, 1991, p. 78-79). 
Psicologia educacional, de Nelson Piletti, em sua 17ª edição (2000), na parte relativa à descrição dos estágios de desenvolvimento de Piaget, oferece aos professores uma orientação baseada no mesmo princípio, segundo o qual é preciso adaptar o ensino às características dos alunos para levá-los a aprender. Segundo o autor, aqueles que se encontram no estágio operatório concreto não são capazes de aprender um conceito, por exemplo, o de "democracia", a partir de uma explicação abstrata. Precisam vivenciá-lo na prática. Nesse livro didático a recomendação atualiza o conselho tradicional de evitar conduzir-se segundo a regra "faça o que eu digo, não faça o que eu faço" (2000, p. 240), sedimentando-o no saber científico sobre o desenvolvimento infantil:

Isso é muito importante para os professores de primeiro grau: a capacidade da criança, dos sete aos doze anos, volta-se para o desenvolvimento de operações concretas: trabalhar com coisas, objetos - água, terra, madeira, plantas, animais, tudo o que pode ser visto e manipulado - e não com conceitos abstratos. O conceito de democracia, por exemplo, só pode ser entendido, na prática, se for vivido na sala de aula, concretamente, e não apenas como conceito abstrato. Não adianta definir teoricamente, com palavras; é preciso exercitar na prática (PILETTI, 2000, p. 248).

Ainda mais recentemente, em Psicologia da educação (2008), de Marcus Vinícius da Cunha, no capítulo dedicado à exposição da teoria psicogenética de Piaget e suas implicações para a educação lemos a seguinte consideração sobre a conveniência de se ajustar o ensino ao desenvolvimento intelectual dos alunos:

\footnotetext{
Se o professor tiver em mãos um quadro ainda que meramente indicativo, do desenvolvimento intelectual humano, poderá ajustar a metodologia de ensino e os conteúdos das matérias escolares às características de seus alunos, o que trará grandes benefícios ao processo de aprendizagem e ao próprio funcionamento da escola (CUNHA, 2008, p. 66).
}

Outro enunciado recorrente nos manuais de psicologia, muitas vezes associado àquele que se está considerando, estabelecia a existência de diferenças individuais de capacidade. Até a década de 1960, essas diferenças eram referidas principalmente como desigualdade das inteligências. Os discursos da psicologia educacional estabeleciam ligações entre esses enunciados que produziam aproximadamente o seguinte efeito: Dado que os alunos apresentam inteligências desiguais e tendo em vista que só se governa a natureza obedecendolhe, é preciso difundir nas Escolas Normais os conhecimentos científicos da psicologia sobre as crianças, pois os professores devem conhecer as características dos seus alunos e adaptar o ensino às suas possibilidades, para alcançar os resultados desejados, ou seja, promover o ajustamento social dos indivíduos. Nas décadas de 1950 e 1960, a esses enunciados, associa- 
se mais um, o qual faz a crítica da uniformidade dos programas de ensino, explicitamente baseada nos preceitos da Escola Nova.

Afro do Amaral Fontoura dedicava o segundo volume de seu compêndio Psicologia Educacional ao estudo da psicologia diferencial, em que defendia a escola sob medida, recuperando a mesma analogia formulada por Claparède, como pode ser observado nos trechos a seguir, retirados das obras dos dois autores:

Pensou-se várias vezes que, por escola sob medida, eu entendia uma escola onde se mediam os alunos! Nem se precisa dizer que estas palavras significam apenas uma escola adaptada à mentalidade de cada um, uma escola que se acomode tão perfeitamente aos espíritos, quanto uma roupa ou um calçado sob medida o fazem para o corpo ou para o pé (CLAPARÈDE, 1951, p.128)

Ninguém pretende que a pessoa com pé tamanho 40 use sapatos número 38 . Nem vice-versa. Ora, se procuramos ajustar o sapato ao pé do indivíduo, e ajustar o tamanho da roupa ao corpo do comprador, como poderemos exigir que no caso da formação mental todos os alunos se adaptem ao mesmo figurino único, fornecido pelo programa ou pelo mestre? (FONTOURA, 1966, p. 415).

$\mathrm{O}$ enunciado segundo o qual era preciso identificar e respeitar as diferenças individuais por meio de um ensino sob medida ligava-se, na obra de Claparède, à recomendação de que era preciso investir no aperfeiçoamento de suas aptidões naturais e encaminhá-los para as profissões mais condizentes com as suas características. Psicologia diferencial e psicologia educacional associadas, conduzindo à orientação profissional para favorecer a alocação do homem certo para o lugar certo. Tratava-se da conciliação entre o interesse individual e o interesse social. Dedicando-se ao ofício para o qual revelava inclinação espontânea, o indivíduo encontraria satisfação real em seu trabalho e ótimo rendimento. A escola sob medida, fundamentada no estudo psicológico das aptidões, apresentava-se, portanto, como a instituição em que a sociedade simultaneamente proporcionaria ao indivíduo a formação mais condizente com as suas motivações pessoais e a partir da qual obteria deles a melhor contribuição possível. Em tal escola, o professor encontraria condições ideais para o exercício de uma autoridade legítima, pois a sua atuação fundamentar-se-ia em um saber positivo sobre as verdadeiras necessidades de cada um, identificadas por meio da aplicação dos testes psicológicos. Como exemplo desse discurso, pode-se citar:

Os testes de inteligência são individuais ou coletivos. São constituídos de grupos de testes estalonados (sic) e graduados para cada idade mental, e visam a medida das atividades que entram no complexo fenômeno da inteligência, em maior número possível de suas faces. Os resultados obtidos oferecem indicações úteis ao educador, pondo mais ou menos a claro as possibilidades e as falhas de cada um de seus alunos, podendo o mestre orientar-se no seu trabalho escolar, a fim de oferecer atividades 
adequadas a seus alunos, para que apresentem o máximo de rendimento de que seja capaz cada um. $\mathrm{O}$ trabalho escolar deixa de ser trabalho no escuro, às cegas. Procurase, com isso, respeitar mais as diferenças individuais, exigindo de cada aluno o que lhe é possível dar, de acordo com sua possibilidade biológica (PENTEADO JUNIOR, 1949, p. 150).

Essa perspectiva aplicava-se também àqueles identificados como retardados ou superdotados. Os primeiros, desde que submetidos a um ensino condizente com suas forças, podiam tornar-se socialmente aproveitáveis, realizando ofícios simples de maneira independente e contribuindo para a própria subsistência. E os segundos deveriam merecer uma atenção ainda maior na escola, para que não fosse desperdiçado o seu elevado potencial.

Nos manuais mais recentes, o enunciado sobre a necessidade de adaptar do ensino às características individuais associa-se à afirmação de que os alunos atravessam etapas de desenvolvimento e cada um apresenta seu ritmo próprio, que é preciso respeitar. Conforme esse discurso, cabe aos professores identificar o estágio de desenvolvimento em que seus alunos se encontram para proporcionar-lhes os estímulos adequados para o seu avanço. Afirmase que o bom ensino, adaptado às características do aluno, pode intervir no curso do seu desenvolvimento, impulsionando-o, levando-o a se desenvolver cada vez mais, num processo contínuo e ilimitado de ampliação das próprias capacidades. Os exemplos a seguir mostram variações contemporâneas do enunciado que se tratou de perseguir:

\footnotetext{
Gardner considera o desenvolvimento a partir do nascimento, quando a criança tem em média 400 gramas de cérebro, até chegar à vida adulta, com mais ou menos um quilo e meio. Os estímulos devem ser em quantidade suportável, o excesso é prejudicial ao ser humano. Nenhuma criança absorve passivamente o mundo e o desenvolvimento histórico deve ser considerado. Aceita que as pessoas são diferentes. Que a herança genética é importante, mas não preponderante; que os jogos são bons para o desenvolvimento educacional; que a inteligência não se desenvolve de maneira linear e é um processo dialético que acontece durante a vida toda; que as inteligências vão se estruturando a partir dos primeiros reflexos, tornando-se cada vez mais complexas e completas; que cada estágio do desenvolvimento é diferente e a criança vai se transformando, necessitando de estímulos diferentes em cada fase da vida e que o professor precisa compreender os diferentes estágios de desenvolvimento (FRANCISCO FILHO, 2002, p. 111, destaque nosso).
}

Um minucioso trabalho de seleção e ordenamento dos tópicos das matérias faz-se necessário para que os conhecimentos a serem ensinados não estejam no mesmo nível das aquisições já feitas pelo aluno, o que não despertaria sua motivação. Esses conhecimentos não podem estar, também, em nível tão acima que superem as possibilidades inerentes às estruturas cognitivas já adquiridas. Vem daí a noção de desajustamento ótimo, dada a essa tendência (CUNHA, 2008, p. 82).

Convém observar que, no segundo caso, o "desajustamento ótimo" a que se refere o autor consiste ainda na adaptação do ensino às características do aluno, uma adaptação que se pretende ainda mais sofisticada e precisa, ao recomendar que o ensino se adiante ao desenvolvimento na justa medida para impulsioná-lo. Vale notar que essa concepção foi 
amplamente difundida nos discursos da psicologia da educação a partir do conceito de zona de desenvolvimento proximal, formulado por Vygotsky e difundido a partir da publicação da obra A formação social da mente (1998), que se tornou referência constante nos programas de psicologia destinados à formação docente.

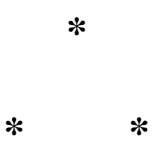

A psicologia educacional desenvolveu-se em torno da pressuposição da desigualdade das inteligências e em função da expectativa de que cada aluno adquirisse, ao final da escolaridade obrigatória, as capacidades e os conhecimentos necessários à sua adaptação à sociedade. Como condição para alcançar esse objetivo, os discursos da disciplina repetidamente enunciaram a necessidade de se adequar o ensino às capacidades das crianças. Atualmente, quando já não se sabe ao certo quais serão as aptidões requeridas no universo cada vez mais instável das profissões do futuro, insiste-se na necessidade de adaptar o ensino às características da etapa de desenvolvimento em que o aluno se encontra, de modo a impulsionar esse mesmo desenvolvimento, num processo sem fim.

De tão insistente, esse enunciado conquistou o status de evidência inquestionável nos discursos pedagógicos. Ao revisitar uma pequena parte da história desse consenso, por meio da análise de um de seus enunciados mais persistentes nos discursos da psicologia oferecidos aos professores em formação, procurou-se criar a possibilidade de discutir o que parece indiscutível. A esta altura, talvez já não pareça tão evidente que os professores devem governar e se deixar governar dessa maneira, ou seja, submetendo-se aos conhecimentos da psicologia sobre as (in)capacidades dos alunos e tomando para si a incumbência de promover o desenvolvimento individual e a adaptação às supostas exigências de um futuro incerto.

Para concluir, pode-se propor um singelo exercício de imaginação: o que poderia acontecer à educação escolar se, alternativamente, se partisse de uma aposta e de uma expectativa contrárias às da posição reinante? Que efeitos (e perigos para a ordem estabelecida) poderia produzir nos discursos e nas práticas pedagógicas a aposta na igualdade das inteligências e a expectativa de que cada educando, sendo único, tende a trilhar relações 
próprias com os conteúdos curriculares comuns a todos, sendo os efeitos da sua passagem pela escola, não completamente controláveis ou previsíveis?

A aposta na desigualdade das inteligências levou, no início do século $\mathrm{XX}$, à criação de instrumentos para a verificação/produção dessas desigualdades, cujo exemplo paradigmático foi a escala métrica da inteligência. Seus principais efeitos nas escolas foram justificar a exclusão dos deficientes mentais das escolas regulares, favorecer a classificação dos alunos normais em "fortes", "médios" e "fracos", tendo em vista a sua separação em classes distintas e sua destinação a posições sociais consideradas adequadas à sua condição de desiguais. Contudo, convém observar que no início do século XIX, um "experimento" levado a efeito por um professor e descrito por Jacques Rancière em $O$ mestre ignorante, ensejou a aposta na igualdade das inteligências, assim como a criação de um modo de verificá-la/produzila. Tratava-se de um método que consistia simplesmente em mostrar ao aluno "o que pode uma inteligência quando ela se considera como igual a qualquer outra e considera qualquer outra como igual à sua". Porque, como observou Rancière, "A igualdade é fundamental e ausente, ela é atual e intempestiva, sempre dependendo da iniciativa de indivíduos e grupos que, contra o curso natural das coisas, assumem o risco de verificá-la, de inventar as formas, individuais ou coletivas, de sua verificação" (RANCIÈRE, 2011, p. 16).

Tal aposta não levaria necessariamente à supressão do enunciado que se tratou de examinar, mas poderia produzir outras associações. Por exemplo, a afirmação de que convém adaptar o ensino às características dos alunos simplesmente para permitir a compreensão mútua. Assim como os pais levam em conta as particularidades de seus filhos ao educá-los e os amigos procuram se adaptar uns aos outros em sua convivência, assim como também os alunos adaptam seu discurso e sua conduta ao dirigir-se a cada um de seus professores. Não porque as inteligências sejam desiguais, mas porque as pessoas são distintas (distantes) ${ }^{20}$.

\footnotetext{
${ }^{20}$ Uma versão anterior desse texto foi publicada em Cadernos de História da Educação. Universidade Federal de Uberlândia: Uberlândia, v. 16, n. 2, mai/ago, 2017, p. 311-333.
} 


\title{
CONCLUSÃO
}

\begin{abstract}
Quem não conhece as "Memórias de um menino de Escola", deste menino do norte brasileiro que Viriato Correia descreve com tanto sentimento no seu "Cazuza"? Que desilusão profunda não experimenta este garoto, ao primeiro contato com a Escola, de que fazia um sonho dourado. "Nada, nada havia lá que me despertasse o interesse ou me tocasse o coração. Ao contrário: como que tudo fora feito para me meter medo. A sala feia, o ar de tristeza, o ar de prisão, a cara feroz do professor... Nunca lhe vi um sorriso no rosto. Vivia sempre zangado, com ar de quem está a ralhar com o mundo, cara amarrada, rugas na testa. Para as criancinhas do meu tamanho representava o papel de lobisomem. Tínhamos-lhe um medo louco. Se estávamos a brincar num terreiro e o percebíamos ao longe, ficávamos silenciosos e quem podia esconder-se - escondia-se; quem podia fugir - fugia. Só depois que ele passava e quando já não lhe víamos mais a sombra, é que o brinquedo recomeçava".
\end{abstract}

Eis o retrato de João Ricardo, professor de primeiras letras, lembrado por Viriato Correia. Não, francamente os João Ricardo não podem ser professores nem de Cazuza nem dos seus pequenos companheiros. Os professores "João Ricardo" não têm o direito de ensinar às crianças desta tenra idade, para não lhes meter medo no coração, para não lhes tirar, às vezes, toda ilusão na vida.

O caráter do professor deve ser ajeitado ao do aluno. E o problema se apresenta de dois modos: ou selecionar o mestre desejado pelos dons inatos que apresenta, ou formar no futuro educador a compreensão, a índole, as atitudes compatíveis com a infância (ANTIPOFF, 2002, 1939, p. 216)

Nas páginas precedentes procurou-se caracterizar alguns aspectos relevantes dos discursos da psicologia difundidos nos cursos de formação de professores, com o propósito de mostrar a articulação entre os saberes psicológicos sobre os alunos e as orientações pedagógicas para o trabalho docente, bem como algumas de suas transformações no decorrer do século XX. A partir de um conjunto de análises que incidiram principalmente sobre discursos da psicologia educacional, evidenciou-se a expectativa de que a psicologia se tornaria o fundamento científico das práticas educativas, contribuindo tanto para a superação dos problemas de aprendizagem e comportamento das crianças que causavam preocupação na escola, quanto para o desenvolvimento e o aprendizado de todos os alunos. Procurou-se apresentar ainda as incertezas e críticas relativas às apropriações da psicologia do campo educacional manifestas nesses mesmos discursos, ainda que de maneira menos recorrente. 
Nem só de confiança na ciência e na técnica se fizeram os discursos da psicologia educacional. Quando a análise se detém sobre os enunciados, observa-se que, embora forte, a confiança na psicologia como ciência capaz de oferecer respostas para os problemas educacionais dividia espaço no discurso com ressalvas, indagações e divergências. Aqui e ali os autores também expressavam dúvidas em relação à relevância, à conveniência ou à eficácia dos dados produzidos pela psicologia para instruir as práticas pedagógicas. Na primeira metade do século XX, a psicologia foi descrita como uma ciência nova, muito promissora, mas ainda em "desenvolvimento". Aparecia mais como uma promessa para o futuro da educação do que como uma fonte de respostas para os problemas enfrentados nas escolas. Observava-se que as teorias psicológicas eram diversas, em certos casos divergentes, o que impedia a formação de respostas consensuais para as questões educativas. Mais tarde, a partir da década de 1970, a psicologia educacional passou a ser desafiada no interior das próprias faculdades de psicologia e pedagogia, a partir da formulação de perspectivas críticas que passaram a questionar os seus procedimentos de investigação, suas aplicações no campo educacional e a legitimidade de suas classificações em uma sociedade como a brasileira, marcada pela profunda desigualdade entre os grupos sociais. Na apresentação do livro Psicologia da educação: fundamentos teóricos, aplicações à prática pedagógica, Iris Barbosa Goulart (2014, p. 7) assim se manifesta:

\footnotetext{
Quando, no final da década de 1970, o posicionamento crítico que derivou da abertura política colocou em questão as contribuições da Psicologia, fui levada a rever não só o papel desta ciência, mas meu próprio papel profissional. A instalação de um discurso sociopolítico, sobre a Educação e a visão da ciência psicológica como instrumento ideológico que mascara a realidade a fim de assegurar a manutenção da estrutura social, fez com que os professores de Psicologia abandonassem o tipo de saber com o qual estavam familiarizados e se sentissem perdidos.
}

Embora continue forte a demanda por saberes psicológicos e pela presença de psicólogos nas escolas, já nas últimas décadas do século XX o ensino da psicologia educacional nos cursos de formação de professores em muitos casos deixou de se apresentar como fundamento científico da educação ou conjunto de verdades sobre a criança, seu aprendizado, seu desenvolvimento. Começou a tomar espaço no discurso da disciplina o enunciado segundo o qual a psicologia corresponde a um agregado de teorias distintas, cada qual com a sua perspectiva própria das questões que interessam à educação. Se nas primeiras décadas do século XX essa condição aparecia como limitação a ser superada com o desenvolvimento futuro da disciplina, atualmente a dispersão das teorias é frequentemente assumida como 
característica desse campo conhecimento e está associada à reformulação das promessas da psicologia relativamente à educação escolar. Passou-se a ponderar que seu ensino poderia contribuir para a formação do professor e proporcionar-lhe uma visão crítica do que se passava na escola e na sociedade, mas não prometia "receitas prontas" para o seu trabalho ou soluções para as dificuldades enfrentadas nas escolas.

Nas primeiras décadas do século $\mathrm{XX}$ a psicologia foi ensinada nas escolas normais principalmente por médicos e advogados que haviam tido o primeiro contato com a disciplina nos tempos de faculdade, quando ela começou a ser divulgada no país como matéria dos cursos de medicina e direito. Posteriormente, egressos das escolas normais passaram a lecioná-la antes ainda da criação das faculdades de psicologia no país. Da década de 1970 em diante, os autores brasileiros da psicologia educacional eram em sua maioria oriundos das faculdades de psicologia, pedagogia, história ou filosofia, em alguns casos egressos de dois cursos superiores e frequentemente portadores de títulos de pós-graduação e docentes no ensino superior. Como característica comum a eles e elas, observou-se a sua familiaridade com a bibliografia estrangeira, notadamente a produzida nos países europeus e nos Estados Unidos, embora não se tenha realizado neste trabalho um estudo mais detido da sua circulação internacional ou dos modos de apropriação das obras estrangeiras em suas produções.

As análises realizadas tomaram a psicologia ensinada aos professores em formação como correspondendo a uma vasta formação discursiva, sem se deter nas distinções indicadas pelas diferentes designações que a disciplina apresentou no decorrer do século XX - psicologia, psicologia educacional, psicologia da educação, psicologia escolar, psicologia e educação etc. - as quais não se sucederam numa sequência linear, mas ainda hoje coexistem. Como bem evidenciaram Deborah Rosária Barbosa e Marilene Proença no artigo "Psicologia Educacional ou Escolar? Eis a questão", o surgimento de novas expressões para designar as aproximações entre a psicologia e a educação escolar expressam mudanças de perspectiva e disputas relevantes no interior da disciplina, cuja descrição consiste em uma contribuição importante para a história da educação e da psicologia (2012). A razão pela qual as análises aqui apresentadas não se detiveram sobre essa questão é que essas distinções de nomenclatura, embora sejam indicativas de mudanças nos modos de se conceber as relações entre a psicologia e a educação, não correspondem à delimitação de fronteiras claras entre discursos, como as autoras bem registram no texto mencionado e como se pode verificar a partir da análise dos manuais de psicologia destinados à formação docente. Para os propósitos desta investigação, pareceu mais adequado considerar as diferentes perspectivas e os posicionamentos divergentes 
como parte de uma mesma formação discursiva heterogênea, que tomando o aluno e a educação escolar como objetos de investigação e, dirigindo-se aos professores, pretendeu contribuir para a transformação das práticas pedagógicas.

Observou-se que boa parte dos manuais de psicologia educacional publicados no Brasil até o surgimento dos cursos de psicologia no país constituem-se de sínteses e comentários da produção estrangeira e das primeiras pesquisas realizadas no Brasil. Em alguns casos, esses livros foram escritos por professores das escolas normais que se desdobraram na escrita de compêndios das diversas matérias que compunham o currículo das escolas normais; eram autodidatas que realizavam o seu trabalho no interior das bibliotecas e afastados dos laboratórios. Mas, à medida que se criavam os primeiros laboratórios de psicologia experimental associados às escolas normais e as primeiras clínicas de orientação infantil associadas às redes de ensino primário, os primeiros pesquisadores, que frequentemente atuavam também como professores nas escolas normais e, posteriormente, nas faculdades de pedagogia e psicologia, passaram a publicar os resultados dos seus trabalhos, dando a conhecer as suas pesquisas sobre as crianças brasileiras. Essa produção se torna ainda mais expressiva com a criação dos cursos de pós-graduação no país e a formação de grupos de pesquisa dedicados ao estudo de questões relativas à educação escolar a partir de uma perspectiva psicológica nas diversas universidades.

A psicologia experimental e a psicanálise tiveram uma presença forte na psicologia educacional e originaram procedimentos de investigação, descrições da criança e orientações distintos, tendo sido empregados às vezes de maneira combinada no estudo dos problemas dos escolares, às vezes de maneira concorrente. Já nas primeiras décadas do século XX a psicologia experimental foi introduzida no Brasil para o estudo dos escolares, que passou a ser realizado nos laboratórios anexos às escolas normais. Por meio da aplicação de testes psicológicos para a identificação e a mensuração das aptidões naturais dos alunos, pretendeu-se realizar a classificação das turmas de acordo com o parâmetro do quociente de inteligência, de modo a tornar possível a adaptação dos currículos, das práticas escolares e dos próprios professores às possibilidades dos estudantes, tornando o ensino mais racional e eficiente.

A medida objetiva das capacidades e o ajustamento das práticas ao nível dos alunos aparecia como solução científica de uma série de problemas enfrentados nas escolas e na sociedade: a identificação da debilidade mental; a discrepância entre o rendimento dos alunos em uma mesma turma, mesmo entre os avaliados como "normais'; à orientação profissional; a 
avaliação do trabalho dos professores. Além dos testes de Q.I., difundiram-se no país e no exterior os testes A.B.C. para a avaliação da maturidade para o aprendizado da leitura e da escrita, instrumento criado por Lourenço Filho na tentativa de solucionar o problema da reprovação massiva na primeira série da escola primária. Nem por isso os testes psicológicos deixaram de ser alvo de questionamentos, como se procurou mostrar por meio da apresentação das ressalvas formuladas por diversos autores.

O tema da "influência do meio" no desempenho escolar e nos problemas de comportamento apresentados por certos alunos foi objeto de estudo dos especialistas que se dedicaram à difusão da psicanálise no campo educacional. Considerando insatisfatórias os procedimentos e explicações fornecidos pela psicologia experimental, esses autores devotaram-se à investigações mais amplas e mais profundas da psicologia da criança compilando dados da história do desenvolvimento individual, considerando suas condições de saúde, os cuidados recebidos na primeira infância, a rotina familiar e a dinâmica das relações afetivas no interior do lar. Buscaram ainda, por meio da observação do comportamento e de entrevistas com a própria criança, acessar suas fantasias, desejos e medos inconscientes. Alguns desses estudos foram realizados em serviços destinados ao atendimento da "criança-problema" associados à rede escolar pública, como os que funcionaram nas cidades do Rio de Janeiro e de São Paulo a partir da década de 1930 e foram apresentados no terceiro capítulo. Na perspectiva da psicanálise, o que se deveria fazer não era classificar as crianças de acordo com a medida da sua inteligência, mas descobrir e eliminar as causas dos conflitos que prejudicavam ou impediam o seu desenvolvimento. Assim como a psicologia experimental, a psicanálise produziu tanto esperanças quanto desconfiança e inclusive rejeição no campo educacional. As análises realizadas nos capítulos precedentes não se detiveram no exame dos efeitos da divulgação da psicanálise no campo educacional e não descreveram as ressalvas e os questionamentos que se fizeram aos seus pressupostos e aplicações, mas eles também podem ser encontrados nas páginas dos manuais de psicologia educacional destinados a professores em formação, como por exemplo no livro Psicologia Educacional de Afro do Amaral Fontoura, para quem "há uma evidente exageração pessimista e depressiva nas palavras de FREUD, que também considera, conforme dissemos, toda a criança como um perverso inato. Não podemos aceitar tal pan-sexualismo" (FONTOURA, 1968, p. 222, destaques do autor). Em Educação e Psicanálise, Arthur Ramos se referia às restrições que se faziam à aplicação da psicanálise na educação, dizendo: "Não tem faltado, porém, opositores a toda intervenção da psicanálise na 
escola. Ao lado das críticas gerais dirigidas ao método, surgem outras objeções sobre a sua aplicação à pedagogia” (RAMOS, 1934, p. 16-17).

A psicologia experimental e a psicanálise compareceram nos discursos da psicologia educacional, principalmente quando se tratava de investigar os problemas apresentados pelas crianças que se afastavam da normalidade, porque não aprendiam ou não se comportavam de acordo com as expectativas dos professores. A psicologia do desenvolvimento derivada da teoria biológica da evolução, por sua vez, serviu à descrição das aquisições gradativas feitas pelas crianças com o passar do tempo e da evolução dos seus interesses, contribuindo para estabelecer os parâmetros da normalidade para cada faixa etária. Sua incorporação no discurso educacional se fez acompanhar de recomendações para a reformulação dos currículos, que deveriam ser adaptados à psicologia infantil, em vez de seguir a lógica dos adultos. Na primeira metade do século $\mathrm{XX}$, a psicologia evolutiva prestou-se ainda a referendar no campo educacional a tese do determinismo biológico, apresentando como referência fundamental a obra de Spencer, para quem a herança determinava os limites do desenvolvimento possível para os diferentes grupos humanos. A teoria da recapitulação foi frequentemente apresentada nos manuais de psicologia educacional e tornou-se objeto de dissensões, sendo às vezes apresentada como a expressão da verdade, às vezes questionada por estabelecer uma aproximação entre a psicologia da criança e a dos povos considerados primitivos e dos animais, aproximação que foi considerada discutível para alguns autores e inaceitável para outros, como os educadores da vertente católica.

A análise apresentada no último capítulo deteve-se sobre um enunciado recorrente nos discursos da psicologia educacional até os dias de hoje, segundo o qual é preciso adaptar o ensino às características do aluno. $\mathrm{O}$ exame dos modos de aparição desse enunciado nos manuais de psicologia educacional no decorrer do século XX permite afirmar que a psicologia transmitida aos professores em formação constituiu-se como um campo do saber politicamente ambíguo.

A psicologia foi considerada como uma disciplina que permitiria desafiar as desigualdades de oportunidades relativas à condição social. Os testes psicológicos pareciam um recurso capaz de identificar as aptidões naturais dos indivíduos e, assim, contribuir para a organização de um sistema de ensino aberto a todos e adaptado às capacidades individuais de cada um. Contudo, esse mesmo recurso fez da criança um objeto para uma ciência, transformou-a em coisa mensurável, classificável e manipulável. Assim, por um lado, a 
psicologia experimental promoveu a reificação das características psicológicas como atributos independentes das condições sociais vividas pelos indivíduos testados, legitimando a desqualificação e o descrédito que pesam sobre as crianças e adolescentes cuja cultura não é reconhecida pelos psicólogos, como já foi evidenciado por uma extensa produção acadêmica sobre a psicologização do ensino (SOUZA et al, 1989; MOYSÉS \& COLLARES, 1995, 1997; MACHADO \& SOUZA, 2004; PATTO, 2015 etc.). Por outro lado, e esse aspecto parece ter sido menos considerado nos estudos contemporâneos sobre a história da disciplina, a psicologia educacional participou no processo de civilização dos professores, de suavização das maneiras no trato com as crianças. Como bem observou Norbert Elias no texto "A civilização dos pais", a produção e a divulgação dos conhecimentos especializados sobre as crianças, tornou os pais mais conscientes das eventuais consequências de suas ações para o desenvolvimento e o futuro das crianças, o que representou uma transformação importante nas antigas relações entre adultos e crianças:

\begin{abstract}
Durante um longo período, a relação de pais e filhos fora determinada, em grande medida, por costumes tradicionais que davam maior liberdade aos impulsos instintivos espontâneos, tanto dos pais, como dos filhos. As prescrições fundadas em reflexões científicas, ou apresentadas nesses termos, quase não desempenhavam papel algum para a vivência da relação entre pais e filhos. Para as pessoas de nossos dias, não é fácil imaginar uma situação na qual os pais, em seu comportamento frente aos filhos, estavam influenciados apenas por conhecimentos básicos sobre a peculiaridade das crianças, ou seja, sobre as diferenças entre a estrutura da personalidade infantil e a adulta. Os pais greco-romanos e os medievais não se perguntavam, como é feito, atualmente, com frequência: Não estou cometendo erros no meu comportamento com meus filhos? Não estou prejudicando-o, ao fazer isto ou aquilo? Comportavam-se de modo muito mais espontâneo, em geral, estavam muito mais influenciados pelo que eles mesmos sentiam, do que pela intenção de se colocar no lugar das crianças. Estavam mais influenciados pelo que as crianças significavam para eles, do que pelo pensamento do que eles mesmos e seus atos podiam significar para elas (ELIAS, 2012, s.p.)
\end{abstract}

Como sugere a longa citação no início dessas considerações finais, pode-se supor que transformação análoga à descrita por Elias nas relações entre pais e filhos ocorreu nas relações entre professores e alunos. Ao fazer retornar tantas vezes e em tantas versões esse enunciado fundamental - é preciso adaptar o ensino às características do aluno - a psicologia ensinada nos cursos de formação docente contribuiu para legitimar institucionalmente a empatia dos professores pelos alunos. As professoras foram instadas a exercer um autocontrole intensificado, não apenas abstendo-se de agredir os alunos no intuito de discipliná-los, mas também procurando colocar-se no lugar da criança, ouvi-la e compreendê-la. Foram levadas a refrear seus impulsos pedagógicos e encorajadas a considerar os efeitos de suas atitudes e exigências na formação de seus alunos. 
Tem sido observado por diversos pesquisadores que a divulgação dos conhecimentos da psicologia no campo educacional teve como efeito enfraquecer a ação dos professores, que se tornaram cada vez mais submetidos ao saber dos psicólogos sobre as individualidades das crianças, hesitantes sobre se podem ou não, devem ou não, ensinar e corrigir seus alunos e, quando podem, sobre quais as maneiras autorizadas de fazê-lo, tendo em vista a etapa de desenvolvimento do aluno e as possibilidades, necessidades e interesses individuais de cada um (LAJONQUIÈRE, 1998; VOLTOLINI, 2001). Mas, como foi observado no primeiro capítulo, a forte presença dos conhecimentos da psicologia da criança na formação docente e nas escolas também fez com que os professores se tornassem socialmente reconhecidos como especialistas em crianças e assumissem sua posição de autoridade diante das famílias, como costuma acontecer nas reuniões de pais e mestres.

Estariam os professores e seus alunos em melhores condições na ausência de qualquer psicologia? Impossível saber, mas decerto as escolas seriam diferentes do que são. A própria compreensão do que somos, do que nos tornamos como indivíduos escolarizados exige levar em conta o "acontecimento" da introdução da psicologia no campo educacional. Essa aproximação, que se tornou mais evidente nos discursos pedagógicos brasileiros a partir da década de 1920, é contemporânea da difusão internacional dos sistemas públicos de ensino, ocorrida na passagem do século XIX para o século XX. A criação da escala métrica da inteligência ocorreu em 1904, para solucionar o problema do baixo rendimento escolar, poucos anos após a instituição da escola pública seriada para toda a população na França. A escola, tal como a conhecemos e a frequentamos, ensejou tanto a produção do aluno como da psicologia da criança. Não cabe, portanto, louvar a psicologia como um conhecimento estrangeiro que chega à escola para salvar os professores e os alunos, ou, pelo contrário, criticá-la como um saber alienígena que invade a escola para colonizá-los e submetê-los a um poder externo. Em vez disso, cabe analisá-la como parte integrante da cultura escolar moderna e descrever, em suas especificidades e variações, os diferentes modos pelos quais os discursos e os procedimentos psicológicos têm participado das práticas escolares.

A psicologia educacional é contemporânea da instituição dos sistemas públicos de ensino e tem sido, desde suas primeiras formulações, um domínio de contornos epistemológicos incertos e contestados, no âmbito do qual tem sido pensados problemas importantes acerca da escola e também formulados novos problemas e modos de pensar sobre 
temas importantes para a vida escolar, dentre os quais as dificuldades enfrentadas por parte das crianças e dos professores em seu cotidiano escolar.

Em muitos trabalhos têm sido destacados os prejuízos de certas explicações e procedimentos da psicologia para se pensar e enfrentar as dificuldades vividas na escola. É possível que esses prejuízos estejam associados à expectativa de que a psicologia possa oferecer soluções para problemas que ultrapassam a esfera de atuação da própria escola, como é o caso das profundas desigualdades sociais que caracterizam o Brasil. Sendo assim, o estudo dos resultados indesejáveis da interação entre a psicologia e a educação pode contribuir como uma forma de advertência contra os muitos erros já cometidos e suas consequências perversas. Contudo, rejeitar simplesmente a psicologia pode ter como efeito indesejado ver seus perigos ressurgirem em uma nova disciplina, considerada enfim científica e capaz de responder, quem sabe a partir de estudos sobre o funcionamento do cérebro, as mesmas questões e oferecer orientações análogas às que, por aproximadamente um século, se esperou da psicologia.

Ao lado do exame rigoroso das consequências perniciosas da psicologia aplicada à educação, pode ser produtivo considerar também as suas contribuições, que incluem as questões importantes que procurou enfrentar, mesmo que essas questões atualmente já não devam ser formuladas nos mesmos termos, tendo em vista a transformação dos problemas e dos conhecimentos contemporâneos relativos à educação escolar. Examinar as esperanças e as convicções que caracterizaram a psicologia em sua interface com a educação e seus efeitos, compreender em que medida ainda são as nossas ou já deixaram de ser, e por quais razões, pode ser relevante para elaborar um diagnóstico do presente, de acordo com a expressão consagrada no domínio dos estudos foucaultianos. Pode, em suma, contribuir para elucidar - e, por ventura, alterar - nossa persistente vontade de verdade e de poder. 


\section{REFERÊNCIAS ${ }^{21}$}

ADRADOS, Isabel. Orientação Infantil. 5a . ed., Petrópolis: Vozes, 1983.

ALMEIDA, José de. Noções de psicologia aplicada à educação. São Paulo: Companhia Editora Nacional, 1947.

ANGELINI, Arrigo Leonardo; PFROMM NETTO, Samuel. \& ROSAMILHA, Nelson. Análise de conteúdo de psicologia educacional. Psicologia escolar e educacional, 5(1), 2001, p.83-90.

ANTIPOFF, Helena. Como pode a escola contribuir para a formação de atitudes democráticas? (1944) In: CAMPOS, Regina Helena de Freitas (org.) Helena Antipoff: textos escolhidos. São Paulo: Casa do Psicólogo; Brasília: Conselho Federal de Psicologia, 2002, p. 221-226.

. Das classes homogêneas (1935). In CAMPOS, Regina Helena de Freitas (org).

Helena Antipoff: textos escolhidos. São Paulo: Casa do Psicólogo; Brasília: Conselho Federal de Psicologia, 2002, p. 213-214.

Dos perfis caracterológicos como elemento de educação democrática (1945)

In: Helena Antipoff: textos escolhidos. Regina Helena de Freitas Campos (Organizadora). São Paulo: Casa do Psicólogo; Brasília: Conselho Federal de Psicologia, 2002, p. 227-236.

Infância Excepcional. Belo Horizonte: Secretaria de Educação e Saúde Pública de Minas Gerais, 1937. (Boletim 20).

O desenvolvimento mental das crianças de Belo Horizonte. In CAMPOS, Regina Helena de Freitas (org.). Helena Antipoff: textos escolhidos. São Paulo: Casa do Psicólogo; Brasília: Conselho Federal de Psicologia, 2002/1931, p.83-125.

O educador em face da criança. In CAMPOS, Regina Helena de Freitas (org.).

Helena Antipoff: textos escolhidos. São Paulo: Casa do Psicólogo; Brasília: Conselho Federal de Psicologia, 2002/1939, p. 215-219.

${ }^{21}$ De acordo com a ASSOCIAÇÃO BRASILEIRA DE NORMAS TÉCNICAS (ABNT NBR 6023) 
Organização das classes nos grupos escolares de Belo Horizonte (1931). In:

CAMPOS, Regina Helena de Freitas (org)., Helena Antipoff: textos escolhidos. São Paulo: Casa do Psicólogo; Brasília: Conselho Federal de Psicologia 2002, p. 197-211.

ANTUNES, Mitsuko Aparecida Makino; RONCA, Antonio Carlos Caruso. Manoel Bomfim (1868-1932): um educador esquecido. In REGO, Teresa Cristina. Educadores brasileiros: ideias e ações que marcaram a educação nacional. Curitiba: CRV, 2018, p. 29-39.

ANTUNES, Mitsuko Aparecida Makino. A psicologia no Brasil: um ensaio sobre suas contradições. Psicologia: ciência e profissão, v.32, p.44-65, 2012. Número especial.

A psicologia no Brasil: leitura histórica sobre sua constituição ( $5^{a}$ ed.). São Paulo: Unimarco/Educ, 2007.

Bomfim, Manoel José do (1868-1932). In: CAMPOS, Regina Helena de Freitas. Dicionário biográfico da psicologia no Brasil. Rio de Janeiro: Imago; Brasília, DF: CFP, 2001, p.92-94.

Sampaio Dória, Antonio de. (1883-1964). In: CAMPOS, Regina Helena de Freitas. Dicionário biográfico da psicologia no Brasil. Rio de Janeiro: Imago; Brasília, DF: CFP, 2001, p. 340-341.

AQUINO, Julio Groppa. Confrontos na sala de aula. São Paulo: Summus, 1996.

Do cotidiano escolar: ensaios sobre a ética e seus avessos. São Paulo: Summus, 2000

Docência, poder e liberdade: dos processos de governamentalização à potência de existir nas escolas. São Paulo, 2009, 210 p. Tese (Livre-docência), Faculdade de Educação, Universidade de São Paulo.

O controverso lugar da psicologia na educação: aportes para a crítica da noção de sujeito psico-pedagógico. Psicologia: ensino \&formação. 5(1): p.5-19, 2014.

ARIÈS, Philippe. História Social da Criança e da Família. 2a . ed., São Paulo: Livros Técnicos e Científicos, 1981. 
AZANHA, José Mário Pires. Cultura escolar brasileira: um programa de pesquisas. In: Revista USP. V.65, p. 65-69, dez-fev, 1990-1991.

AZEVEDO, Nelson Cunha de. Psicologia Educacional. São Paulo: Companhia Editora Nacional, 1936.

BACON, Francis. Novum Organum: ou verdadeiras indicações acerca da interpretação da natureza. Pará de Minas: Virtual Books, 1620/2003.

BALDWIN, James Mark. Mental Development in Child and Race. Edição inicial 1895.

Disponível em: < http://psyclassics.yorku.ca/Baldwin.htm>. Acesso em: set. 2019.

BAPTISTA, Marisa Todescan Dias da Silva. Rudolfer, Noemy da Silveira (1902-1988). In: CAMPOS, Regina Helena de Freitas. Dicionário biográfico da psicologia no Brasil. Rio de Janeiro: Imago; Brasília, DF: CFP, 2001, p. 337-340.

BARBOSA, Deborah Rosária; SOUZA, Marilene Proença Rebello. Psicologia Educacional ou Escolar? Eis a questão. Revista Semestral da Associação Brasileira de Psicologia Escolar e Educacional. São Paulo, v. 16, n.1, p.163-173, jan/jun, 2012.

BARBOSA, Rejane Maria; MARINHO-ARAÚJO, Clasy Maria. Psicologia escolar no Brasil: considerações e reflexões históricas. Estudos de Psicologia. Campinas, v.27, n.3, p. 393-402, jul/set., 2010.

BAUTHENEY, K. Pedagogia e psiquiatria: um estudo sobre relações entre campos. Curitiba: Appris, 2018.

Transtornos de aprendizagem: quando "ir mal na escola" torna-se um problema médico e/ou psicológico. São Paulo, 2011, 223 p. Tese (Doutorado) Faculdade de Educação, Universidade de São Paulo.

BELLO, Ruy de Ayres. Introdução à Psicologia Educacional. $2^{a}$. ed., São Paulo: Editora do Brasil, 1964.

Pequena História da Educação. São Paulo: Editora do Brasil, 1962. 
BINET, Alfred; SIMON, Theodore. Le development de l'intelligence chez les enfants. L’Année Psychologique, v. 14, n.1, p. 1-94, 1907 apud ZAZZO, René. Alfred Binet. Recife: Fundação Joaquim Nabuco, Editora Massangana, 2010.

. Testes para a medida do desenvolvimento da inteligência. São Paulo:

Melhoramentos, 1929.

BISSERET, Noëlle. A ideologia das aptidões naturais. In DURAND, José Carlos Garcia (Org.). Educação e hegemonia de classe: as funções ideológicas da escola. Rio de Janeiro: Zahar, 1979, p. 31-67.

BOMFIM, Manoel. Lições de pedagogia: teoria e prática de educação. Rio de Janeiro: Francisco Alves, 1920.

Noções de psychologia. 2a . ed., Rio de Janeiro: Francisco Alves, 1917.

BONOW, Iva Waisberg. Psicologia educacional e desenvolvimento humano. $5^{\text {a }}$. ed. São Paulo: Companhia Editora Nacional, 1972.

BONTEMPI JUNIOR, Bruno. Do Instituto de Educação à Faculdade de Filosofia da Universidade de São Paulo. Cadernos de Pesquisa. V. 14, n. 142, p. 188-207, jan/abr, 2011.

BOTO, Carlota. Sampaio Dória (1883-1964): política, democracia e instrução pública. In REGO, Teresa Cristina. Educadores brasileiros: ideias e ações que marcaram a educação nacional. Curitiba: CRV, p. 53-64, 2018.

BRIQUET, Raul. História da Educação: evolução do pensamento educacional. São Paulo: Renascença, 1946.

CAMPOS, Regina Helena de Freitas et al. Funcionalismo no Brasil : Pioneiros. In MASSIMI, Marina. (org). História da Psicologia no Brasil do Século XX. São Paulo: EPU, 2004a, p. 155-174.

CAMPOS, Regina Helena de Freitas et al. A expansão da perspectiva funcionalista no Brasil: a psicologia como disciplina universitária e a problematização da cultura brasileira. In MASSIMI, M. (org). História da Psicologia no Brasil do Século XX. São Paulo: EPU, 2004b, p. 175-198. 
CAMPOS, Regina Helena de Freitas.; LOURENÇO, Érika; ANTONINI, Isabel Gontijo. Introdução: Helena Antipoff e a Psicologia no Brasil. In: CAMPOS, Regina Helena de Freitas (org.) Helena Antipoff: textos escolhidos. São Paulo: Casa do Psicólogo; Brasília: Conselho Federal de Psicologia, 2002.p. 13-36.

CAMPOS, Zaira de Moura. História da Educação. Ribeirão Preto: Ellos, 1972.

CANDIOTTO, Cesar. Foucault: uma história crítica da verdade. Trans/Form/Ação, São Paulo, 29 (2): 65-78, 2006.

Foucault e a crítica da verdade. 2a . ed., Belo Horizonte: Autêntica; Curitiba: Champagnat, 2013.

CARDOSO, Ofélia Boisson. Problemas da meninice. 2a. ed., São Paulo: Melhoramentos, 1964.

CARVALHO, J.S. A produção do fracasso escolar: a trajetória de um clássico. Psicologia USP, São Paulo, 22 (3), p.569-578, 2011.

CARVALHO, Marta Maria Chagas de. A escola e a República. São Paulo: Brasiliense, 1989. Sampaio Dória. Recife: Fundação Joaquim Nabuco, Editora Massangana, 2010. Quando a história da educação é a história da disciplina e da higienização das pessoas. In FREITAS, Marcos Cezar de. (org.) História social da infância no Brasil. São Paulo: Cortez/USF, 1997.

CASASSANTA, Guerino. Manual de Psicologia Educacional. 2a . ed. São Paulo, Editora do Brasil 1955.

CATANI, Denice Barbara. Lourenço Filho (1897-1970): uma vida dedicada à educação. In: REGO, Terese Cristina. Educadores brasileiros: ideias e ações de nomes que marcaram a educação nacional. Curitiba, CRV, 2018, p. 101-111.

CATANI, Denice Barbara; BASTOS, Maria Helena Câmara. Educação em Revista: a imprensa periódica e a história da educação. São Paulo: Escrituras, 1997.

CLAPARÈDE, Édouard. A escola e a psicologia experimental. São Paulo: Melhoramentos, 1928. 
A escola sob medida. Rio de Janeiro: Fundo de Cultura, 1951.

CHERVEL, André. História das disciplinas escolares: reflexões sobre um campo de pesquisa. Teoria \& Educação, Porto Alegre, n. 2, p. 177-229, 1990.

CYSNEIROS, Paulo Gileno. Antipedagogia do livro-texto de psicologia educacional. Revista Brasileira de Estudos Pedagógicos, 66(152), p.47-64, 1985.

COMÉNIO, João Amós. Didática Magna. Tratado da arte universal de ensinar tudo a todos. $3^{\text {a }}$. ed. Lisboa: Fundação Calouste Gulbenkian, 1985 (1632).

CÓRIA-SABINI, Maria Aparecida. Fundamentos de psicologia educacional. $3^{\text {a }}$. ed., São Paulo: Ática, 1991.

COSTA, Jurandir Freire. História da Psiquiatria no Brasil: um corte ideológico. Rio de Janeiro: Documentário, 1976.

. Ordem Médica e Norma Familiar. 5ª ed., Rio de Janeiro: Graal, 2004.

CUNHA, Marcus Vinícius. Psicologia da educação. Rio de Janeiro: DP\&A, 2000.

Psicologia da educação. 4a . ed., Rio de Janeiro: Lamparina, 2008.

DARWIN, Charles. A Biographical Sketch of an Infant. Primeira publicação em Mind, n.2, p. 285-294, 1877. Disponível em: < http://psychclassics.yorku.ca/Darwin/infant.htm> Acesso em: 23 set. 2019.

DAVIS, Cláudia; OLIVEIRA, Zilma de. Psicologia na educação. $2^{\mathrm{a}}$. ed. rev., São Paulo: Cortez, 1994.

DEWEY, John. Vida e educação. São Paulo: Melhoramentos, 1930.

DONZELOT, Jacques. A polícia das famílias. 3ª ed., Rio de Janeiro: Graal, 2001.

DÓRIA, Antonio Sampaio. Educação. São Paulo: Companhia Editora Nacional, 1933.

Psychologia. São Paulo: Tipografia do Instituto Anna Rosa, 1926.

EDDINE, Eder Ahmad Charaf. Desenvolvimento e aprendizagem em manuais didáticos de psicologia educacional. Jundiaí: Paco Editorial, 2013. 
ELIAS, Norbert. Au delà de Freud: sociologie, psychologie, psychanalyse. Paris, Éditions la découverte, 2010.

A civilização dos pais. Revista Sociedade e Estado. V. 27, n. 3, p.469-493, set/dez, 2012.

FERRAZ, João de Sousa. Noções de psicologia educacional. São Paulo: Saraiva, 1957.

FERREIRA, Antonio Gomes. A criança e o seu desenvolvimento em discursos médicos e pedagógicos que circularam no contexto português (séculos XVIII a XX). Educação em Revista. Belo Horizonte, v. 26, n. 01, p. 215-234, abr., 2010.

FERREIRA, May Guimarães. Psicologia educacional: análise crítica. São Paulo: Cortez/Autores Associados, 1986.

Repensando a psicologia educacional. São Paulo: Cortez/Autores Associados, 1986.

FERRIÈRE, Adolphe. A lei biogenética e a escola ativa. São Paulo: Melhoramentos, 1929.

FISCHER, Rosa Maria Bueno. Trabalhar com Foucault: arqueologia de uma paixão. Belo Horizonte: Autêntica, 2012.

Foucault e a análise do discurso em educação. Cadernos de Pesquisa. n.114, p. 197-223, nov/2001.

FONTOURA, Afro do Amaral. Psicologia educacional. $1^{\mathrm{a}}$. parte Psicologia da Criança. $17^{\mathrm{a}}$. ed. Rio de Janeiro: Aurora, 1969.

Psicologia educacional. $2^{\mathrm{a}}$ e $3^{\mathrm{a}}$. partes Psicologia da Aprendizagem; Psicologia Diferencial. 11 a . ed. Rio de Janeiro: Aurora, 1966.

Fundamentos da Educação: princípios psicológicos e sociais, elementos de didática e administração escolar, Rio de Janeiro: Aurora 1949.

Fundamentos da Educação: princípios psicológicos e sociais, elementos de didática e administração escolar, $8^{\text {a }}$. ed., Rio de Janeiro: Aurora, 1965.

Sociologia educacional. Rio de Janeiro: Aurora, 1951. 
. Sociologia educacional. $17^{\mathrm{a}}$. ed., Rio de Janeiro: Aurora, 1967).

. Metodologia do Ensino Primário. Rio de Janeiro: Aurora, 1955. e 16ª ed. em 1966);

. Metodologia do Ensino Primário. 16ª.ed., Rio de Janeiro: Aurora, 1966).

. Psicologia Geral: para as faculdades de filosofia. Rio de Janeiro: Aurora, 1957.

Psicologia Geral: para as faculdades de filosofia. 15a. ed., Rio de Janeiro: Aurora, 1967.

FOUCAULT, Michel. A arqueologia do saber. $7^{\text {a }}$ ed., Rio de Janeiro: Forense Universitária, 2004.

A ordem do discurso: aula inaugural no Collège de France, pronunciada em 2 de dezembro de 1970. 20a . ed., São Paulo: Loyola, 2010.

A história da loucura na Idade Clássica. São Paulo: Perspectiva, 2000.

O que é um autor? 2a . ed, s.l., Vega/Passagens, 1992.

. Verdade e subjetividade (Howison Lectures). Revista de Comunicação e linguagem. N. 19. Lisboa: Edições Cosmos, p.203-223, 1993.

. A psicologia de 1850 a 1950. In: Problematização do sujeito: psicologia, psiquiatria e psicanálise. $2^{\text {a }}$. ed. Rio de Janeiro: Forense, 2002 (Ditos \& escritos, 1), p. 133151.

FRANCISCO FILHO, Geraldo. A psicologia no contexto educacional. Campinas: Átomo, 2002.

FRELLER, Cíntia Copit. Crianças portadoras de queixa escolar: reflexões sobre o atendimento psicológico. In MACHADO, A; PROENÇA, M.M. Psicologia escolar: em busca de novos rumos. 4ª ed., São Paulo: Casa do Psicólogo, 2004.

GALVÃO, Izabel. Cenas do cotidiano escolar: conflito sim, violência não. Petrópolis: Vozes, 2008.

GALVÃO, Izabel. Henri Wallon: uma concepção dialética do desenvolvimento infantil. $17^{\mathrm{a}}$. ed. Petrópolis: Vozes, 1995. 
GATTI JÚNIOR, Décio. O Ensino de História da Educação no Brasil: fontes e métodos de pesquisa. Cadernos de História da Educação, Editora da Universidade Federal de Uberlândia, Uberlândia, v. 16, n. 1, p. 64-88, jan./abr. 2017.

GEENEN, Henrique. Compendio de Psychologia. São Paulo: Monteiro Lobato, 1925.

Temperamento e caráter sob o ponto de vista educativo. São Paulo:

Melhoramento, 1928.

GESELL, Arnold. A criança dos 5 aos 10 anos. São Paulo: Martins Fontes, 2002.

GIL, Natália de Lacerda. Escola democrática, meritocracia e seletividade. Primeiro lugar no Primeiro Concurso de Ensaios da Sociedade Brasileira de História da Educação. Tema: História, Política e Educação no Brasil. 2019.

GIOIA, Paula Suzana. A abordagem behaviorista radical transmitida pelo livro de psicologia direcionado à formação de professores (Tese de Doutorado), Pontifícia Universidade Católica de São Paulo, São Paulo, 2001.

GOULART, Iris Barbosa. Psicologia da educação: fundamentos teóricos, aplicações à prática pedagógica. 2a . ed., Petrópolis: Vozes, 2014.

. Psicologia da Educação. Petrópolis: Vozes, 1987.

GOULD, Stephen Jay. A falsa medida do homem. São Paulo: Martins Fontes, 2003.

GOUVÊA, Maria Cristina Soares. \& BAHIENSE, Priscila Nogueira. A narração da história da psicologia do desenvolvimento e da produção sobre a infância nos livros didáticos [Versão eletrônica]. Memorandum, 20, p.70-82, 2011.

GOUVÊA, Maria Cristina; GERKEN, Carlos Henrique de Souza. Desenvolvimento humano: história, conceitos e polêmicas. São Paulo: Cortez, 2010.

GUIMARÃES, Rosângela.; GATTI JÚNIOR, Décio. A institucionalização da disciplina História da Educação na Escola Normal mineira na primeira metade do século XX. Educação, Pontifícia Universidade Católica do Rio Grande do Sul, Porto Alegre, v. 35, n. 1, p. 54-65, jan./abr. 2012. 
GUZZO, Raquel S. L. et al. Psicologia e educação no Brasil: uma visão da história e possibilidades nessa relação. In: Psicologia: Teoria e Pesquisa. v. 26, p. 131-141, 2010. Número especial.

HAMELINE, Daniel. Édouard Claparède. Recife: Fundação Joaquim Nabuco, Editora Massangana, 2010.

JÁCOME, Marília de Queiroz Dias. Apropriações da teoria de Vigotski em livros de psicologia voltados para a formação de professores. (Dissertação de Mestrado) Universidade de Brasília, Brasília, 2006.

JACÓ-VILELA, Ana Maria; JABUR, Fabio; RODRIGUES, Heliana de Barros Conde (orgs.) Histórias da psicologia no Brasil. Rio de Janeiro: UERJ/NAPE, 1999.

JACÓ-VILELA, Ana Maria. História da Psicologia no Brasil: uma narrativa por meio de seu ensino. In Psicologia: ciência e profissão. V.32, p.28-43, 2012. Número especial.

O fracasso escolar como objeto de estudo: anotações sobre as características de um discurso. Cadernos de Pequisa, São Paulo, n. 65, p. 72-77, mai. 1988.

JACÓ-VILELA, Ana Maria et al. Clínicas de orientação : cuidado infanto-juvenil e participação feminina na constituição do campo psi. Revista Psicologia e Saúde, v.9, n. 2, p. 91-105, mai/ago, 2017.

JULIA, Dominique. A cultura escolar como objeto histórico. Revista Brasileira de História da Educação, n. 1, p. 09-43, jan/jun, 2001.

LAJONQUIÈRE, Leandro. A Psicanálise e o Mal-Estar Pedagógico. Revista Brasileira de Educação. São Paulo, n. 8, p. 92-98, 1998.

LANCILLLOTTI, Samira Saad Pulchério. Manuais de psicologia - instrumentos de trabalho utilizados na formação dos professores paulistas (1920-1940). In Cadernos de História da Educação, v.12, n. 1, p. 29-44, jan/jun, 2013.

LEITE, Dante Moreira. O desenvolvimento da criança. São Paulo: UNESP, 1971/ 2010. 
LEMME, Paschoal. O Manifesto dos Pioneiros da Educação Nova e suas repercussões na realidade educacional brasileira. Revista Brasileira de Estudos Pedagógicos. V. 86, n. 212, p. 163-178, jan/abr, 2005.

LIMA, Ana Laura Godinho. A "criança-problema" na escola brasileira: uma análise do discurso pedagógico. Curitiba: Appris, 2018.

LOURENÇO FILHO, M.B. A psicologia no Brasil. In AZEVEDO, Fernando. As ciências no Brasil. v.2, São Paulo: Melhoramentos, 1954, p.263-296.

Introdução ao Estudo da Escola Nova. São Paulo: Melhoramentos, 1930.

Testes ABC: para a verificação da maturidade necessária à aprendizagem da leitura e da escrita. 13. ed. - Brasília: Instituto Nacional de Estudos e Pesquisas Educacionais Anísio Teixeira, 2008.

MACHADO, Roberto. Ciência e saber: a trajetória da arqueologia de Foucault. $2^{\mathrm{a}}$. ed., Rio de Janeiro, Graal, 1981.

MACHADO, Adriana Marcondes; SOUZA, Marilene Proença. As crianças excluídas da escola: um alerta para a psicologia. In: Psicologia escolar: em busca de novos rumos. São Paulo: Casa do Psicólogo, 2004.

MAGAlHÃES, Valentim. Lições de pedagogia. Parte 1: Psychologia. Rio de Janeiro: Laemmert Editores, 1900.

MANIFESTO DOS PIONEIROS DA EDUCAÇÃO NOVA (1932). Fernando de Azevedo (et.al.) Recife: Fundação Joquim Nabuco, Editora Massangana, 2010.

MARCONDES, Durval (org.). Noções gerais de higiene mental da criança. São Paulo: Livraria Martins, 1946.

MARQUES, Juracy Cunegatto. Compreensão do comportamento: ensaio de psicologia do desenvolvimento e suas pautas para o ensino. Porto Alegre: Globo, 1979.

MEDEIROS, Maurício de. Aspectos da psicologia infantil. Rio de Janeiro/São Paulo: Livraria José Olympio, 1952. 
MENDES, Justino. Psicologia educacional: conforme o programa das Escolas Normais de $1^{\circ}$. e 2. Graus. Juiz de Fora: Editora Lar Católico, 1943.

MENEZES, Djacir. Psicologia. Porto Alegre: Livraria do Globo, 1933.

MINAS GERAIS. Decreto no. 8162, de 20 de janeiro de 1928. Regulamento do Ensino Normal.

MONARCHA, Carlos. Escola Normal da Praça: o lado noturno das luzes. Campinas: Editora da Unicamp, 1999.

Lourenço Filho: outros aspectos, mesma obra. Campinas: Mercado de

Letras, 1997.

MOREIRA LEITE, Dante. O caráter nacional brasileiro. São Paulo: Pioneira, 1976.

MOTA, Márcia Elia. Psicologia do desenvolvimento: uma perspectiva histórica. Temas em Psicologia. V. 13, n.2, p. 105-111, 2005.

MOYSÉS, Maria Aparecida A.; COLLARES, Cecília. A. L. Inteligência abstraída, crianças silenciadas: as avaliações de inteligência. Psicologia USP, São Paulo, v. 18, n. 1, p. 63-89, 1997.

Aprofundando a discussão sobre as relações entre desnutrição, fracasso escolar e merenda. Em Aberto, v. 67, p. 33-56, 1995.

NAGLE, Jorge. Educação e Sociedade na Primeira República. São Paulo: EPU/Edusp, 1976.

NÓVOA, António. Relação Escola-Sociedade: novas respostas para um velho problema. In III Congresso Estadual Paulista sobre a Formação de Educadores. Águas de São Pedro, 1994. São Paulo: UNESP, 1996.

Ó, Jorge Ramos do. O governo de si mesmo: modernidade pedagógica e encenações disciplinares do aluno liceal (último quartel do século XIX - meados do século XX). Lisboa: Educa, 2003.

O Manifesto dos Pioneiros da Educação Nova. 1932. Disponível em: $\langle$ http://www.histedbr.fe.unicamp.br/revista/edicoes/22e/doc1_22e.pdf $>$ 
OLINTO, Plínio. Psicologia. Rio de Janeiro: Editora Guanabara, 1934.

ORNELLAS, Maria de Lourdes Soares. Afetos manifestos na sala de aula. São Paulo, Annablume, 2005.

PATTO, Maria Helena Souza. A produção do fracasso escolar: histórias de submissão e rebeldia. $4^{\mathrm{a}}$. ed. revista e ampliada. São Paulo: Intermeios, 2015.

Introdução à psicologia escolar. 3a . ed. São Paulo: Casa do Psicólogo, 1997.

Mutações do cativeiro: escritos de psicologia e política. São Paulo: Hacker Editores/Edusp, 2000.

. Para uma crítica da razão psicométrica. In Mutações do cativeiro: escritos de psicologia e política. São Paulo: Hacker/Edusp, 2000.

Ciência e Política na Primeira República: origens da psicologia escolar. Mnemosine, v.1, n. 0, p. 203-225, 2004.

PENNA, Antonio Gomes. Olinto, Plínio (1886-1956). In: CAMPOS, Regina Helena de Freitas. Dicionário biográfico da psicologia no Brasil. Rio de Janeiro: Imago; Brasília, DF: CFP, 2001.

PEIXOTO, Afrânio. Noções de História da Educação. $3^{\text {a }}$. ed. São Paulo: Companhia Editora Nacional, 1942.

PESSOTTI, Isaías. Dados para uma história da psicologia no Brasil. In Psicologia ano 1, n.1,p. 1-14, mai, 1975.

PENTEADO JUNIOR, Onofre de Arruda. Compêndio de psicologia: problemas de psicologia educacional para o uso das escolas normais. 2a . ed. do autor, São Paulo: 1949.

PIAGET, Jean. O tempo e o desenvolvimento intelectual da criança. In: Problemas de psicologia genética. São Paulo: Abril Cultural, 1978.

PIÉRON, Henri. Psicologia experimental. São Paulo: Melhoramentos, 1927.

PILETTI, Nelson. Psicologia educacional.7 ${ }^{\mathrm{a}}$. ed., São Paulo: Ática, 1989. 
PIMENTEL, Iago. Noções de psicologia aplicadas à educação. $6^{\text {a }}$. ed. Revista. São Paulo: Melhoramentos, s.d.

POPKEWITZ, Thomas. Reconhecendo diferenças e fabricando a desigualdade: ciências da educação, escolarização e abjeção. In: O que a escola faz? Elementos para a compreensão da vida escolar. Uberlândia: EDUFU, 2015, p. 317-343.

PREYER, William. The mind of the Child: observations concerning the mental development of the human being in the first year. New York: Appleton, 1881.

RAMOS, Arthur. A creança Problema: a higiene mental na escola primária. São Paulo: Companhia Editora Nacional, 1939.

. Educação e Psicanálise. São Paulo: Companhia Editora Nacional, 1934.

RANCIÈRE, Jacques. O mestre ignorante: cinco lições sobre a emancipação intelectual. $3^{\text {a }}$. ed., Belo Horizonte: Autêntica, 2011.

REGO, T. C. Vygotsky: uma perspectiva histórico-cultural da educação. Petrópolis: Vozes, 1996.

RESENDE, Lúcia Maria Gonçalves de. Relações de poder no cotidiano escolar. Campinas: Papirus, 1995.

RIBAS, T.F. Foucault: saber, verdade e política. São Paulo: Intermeios, 2017.

RITO, Marcelo. Carne recortada, almas expostas: da visualização escolanovista à utopia do homem aprimorável. Tese (Doutorado em Educação) São Paulo: Faculdade de Educação da Universidade de São Paulo, 2015.

RODRIGUES, Marlene. Psicologia educacional: uma crônica do desenvolvimento humano. São Paulo: Mc Graw-Hill do Brasil, 1976.

ROMANELli, Otaíza de Oliveira. História da Educação no Brasil (1930-1970) 20ª . ed. Petrópolis: Vozes, 1998.

ROSA, M. Psicologia evolutiva. v.1: Problemática do Desenvolvimento. Petrópolis: Vozes, 1983. 
ROSE, Nikolas. A Psicologia Social como uma ciência da democracia. In:

Inventando nossos selfs: psicologia, poder e subjetividade. Petrópolis, Vozes, 2011, p.163208.

Inventando nossos selfs: psicologia, poder e subjetividade. Petrópolis: Vozes, 2011.

Governing the soul: the shapping of the private self. 2nd. ed., London: Free Association Books, 1999.

Psicologia como uma ciência social. Psicologia \& Sociedade, 20 (2), p.155$164,2008$.

ROSE, Nikolas; ABI-RACHED, Joelle M. Neuro. Princeton: Princeton University Press, 2013.

RUDOLFER, Noemy da Silveira. A evolução da psychologia educacional atravez de um histórico da psychologia moderna. São Paulo: Revista dos Tribunais, 1936.

Critérios em uso na moderna psicologia. In: Boletim de Psicologia. V.25, 26

e 27, São Paulo: Sociedade de Psicologia de São Paulo, p.45-53, set/ dez.1955; mar. 1956.

. Introdução à psicologia educacional. 2a . ed., São Paulo: Companhia Editora Nacional, 1961.

SALVADOR, César Coll. Psicologia da educação. Porto Alegre: Artes Médicas Sul, 1999.

SAMPAIO DÓRIA, A. Psychologia. São Paulo: Tipografia do Instituto Anna Rosa, 1926. Princípios de pedagogia. São Paulo: Pocai:Weiss, 1914.

SANTOS, T. M. Noções de Psicologia Educacional. $6^{\text {a }}$. ed. São Paulo: Companhia Editora Nacional, 1955.

Noções de História da Educação. $3^{\text {a }}$. ed. São Paulo: Companhia Editora Nacional, 1951. (Curso de Psicologia e Pedagogia, 2).

SCHWARCZ, Lilia Moritz. O espetáculo das raças: cientistas, instituições e questão racial no Brasil. São Paulo: Companhia das Letras, 1993. 
SILVA, Tomaz Tadeu da. As pedagogias psi e o governo do eu nos regimes neoliberais. In: . Liberdades reguladas: a pedagogia construtivista e outras formas de governo do eu. Petrópolis: Vozes, 1998, p. 7-13.

SILVA, Vivian Batista da. Saberes em viagem nos manuais pedagógicos: construções da escola em Portugal e no Brasil (1870-1970). São Paulo: Editora Unesp, 2018.

SISTO, Fermino Fernandes. O cognitivo, o social e o afetivo no cotidiano escolar. Campinas: Papirus, 1999.

SOUZA, Marilene Proença Ribeiro. Formação do Psicólogo para atendimento a problemas de aprendizagem: desafios e perspectivas. Estilos da Clínica (USP), São Paulo, v.5, n. 9, p. 134$154,2000$.

SOUZA, Marilene Proença Rebello de; MACHADO, Adriana Marcondes; FRELLER, Cíntia Copit; SOUZA, Beatriz Paula de; SOUZA, Denise Trento Rebello de. A questão do rendimento escolar: subsídios para uma nova reflexão. Revista da Faculdade de Educação (USP) São Paulo, v.15, n.2, p. 188-201, 1989.

TAILlE, Y.; OLIVEIRA, Marta Kohl de; DANTAS, Heloysa. Piaget, Vygotsky, Wallon: teorias psicogenéticas em discussão. 17ª . ed. São Paulo: Summus, 1992.

TAVARES, Fausto Ramalho. A ordem e a medida: escola e psicologia em São Paulo (18901930). Dissertação de Mestrado, Universidade de São Paulo, São Paulo, 1995.

VARELLA, Julia. Categorias espaço-temporais e socialização escolar: do individualismo ao narcisismo. Em Costa, M.V. (Org). Escola básica na virada do século: cultura, política e currículo. São Paulo: Cortez, p. 73-106, 1999.

VEIGA-NETO, A. Foucault \& a Educação. 3a . ed., Belo Horizonte: Autêntica, 2011.

VIDAL, Diana Gonçalves. Anísio Teixeira, professor de professoras: um estudo sobre modelos de professor e práticas docentes (Rio de Janeiro, 1932-1935). Revista Diálogo Educacional. Curitiba, v.5, n. 16, p. 293-314, set/dez, 2005.

. 80 anos do Manifesto dos Pioneiros da Educação Nova: questões para debate. In Educação e Pesquisa, São Paulo, v. 39, n. 3, p. 577-588, jul/set, 2013. 
Escola Nova e Processo Educativo. In LOPES, Eliane Marta Teixeira; FARIA FILHO, Luciano Mendes. 500 Anos de Educação no Brasil. 5a . ed., Belo Horizonte: Autêntica, 2011. P. 497-517.

VIGOTSKI, Lev Semenovich. A formação social da mente: o desenvolvimento dos processos psicológicos superiores. $6^{a}$. ed. São Paulo: Martins Fontes, 1998.

VOLTOLINI, Rinaldo. Do contrato pedagógico ao ato analítico: contribuições à discussão da questão do mal-estar na educação. Estilos da Clínica, São Paulo , v. 6, n. 10, p. 101111, 2001.Disponível em:

$<$ http://pepsic.bvsalud.org/scielo.php?script=sci_arttext\&pid=S141571282001000100009\&lng=pt\&nrm=iso > . acessos em 20 ago. 2019.>

WALKERDINE, Valerie. Uma análise foucaultiana da pedagogia construtivista. In SILVA, Tomaz Tadeu da. Liberdades reguladas: a pedagogia construtivista e outras formas de governo do eu. Petrópolis: Vozes, 1998, p. 143-215.

WINNICOTT, Donald. O conceito de indivíduo saudável. In: Tudo começa em casa. São Paulo: Martins Fontes, 2005.

ZAZZO, René. Alfred Binet. Recife: Fundação Joaquim Nabuco, Editora Massangana, 2010. 